\begin{tabular}{c|c} 
University of Szeged & $\begin{array}{c}\text { Kaohsiung Medical University } \\
\text { Department of Pharmacodynamics } \\
\text { and Biopharmacy }\end{array}$ \\
Graduate Institute of Natural \\
Products
\end{tabular}

Ph.D. Thesis

\title{
ANTIPROLIFERATIVE AND ANTIMETASTATIC PROPERTIES OF D-RING MODIFIED ESTROGEN ANALOGS ON CERVICAL CANCER CELL LINES \\ Noémi Bózsity Pharm.D.
}

Supervisors:

Renáta Kanizsainé Minorics Ph.D.

István Zupkó Ph.D.

Prof. Chin-Chung Wu 


\section{TABLE OF CONTENTS}

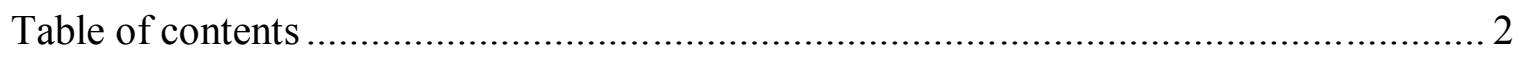

Scientific publication related to the subjects of the thesis ......................................... 4

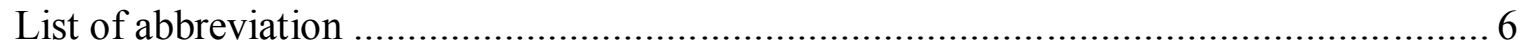

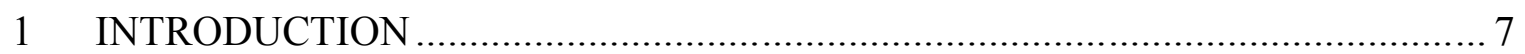

1.1 Epidemiology of cervical cancer ................................................. 7

1.2 General principles of tumor formation and viral oncogenesis ............... 8

1.3 The role of estrogens and estrogen-related compounds in tumor formation 11

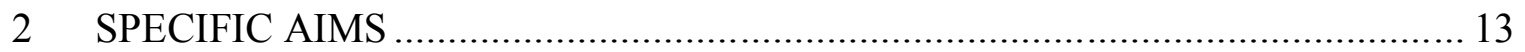

3 MATERIALS AND METHODS ................................................................. 14

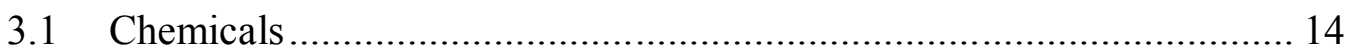

3.2 Cell lines and culturing conditions ............................................. 15

3.3 Antiproliferative MTT assay .................................................. 15

3.4 Hoechst 33258 - propidium iodide (HOPI) double staining ................. 16

3.5 Cell cycle analysis by flow cytometry ............................................ 16

3.6 Determination of in situ caspase activity ..................................... 17

3.7 Distinction of G2 and M phases by specific flow cytometry............... 17

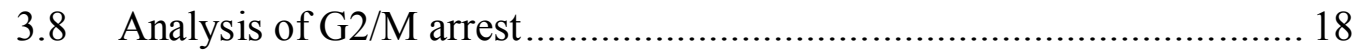

3.8.1 Reverse transcription PCR (RT-PCR) studies ............................. 18

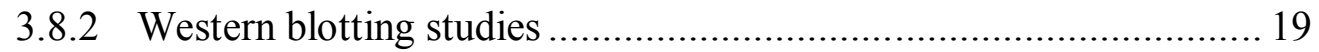

3.9 Tubulin polymerization assay .................................................... 19

3.10 Analysis of cell migration using wound healing assay .................... 20

3.11 Analysis of cell invasion using Boyden chamber assay ................... 20

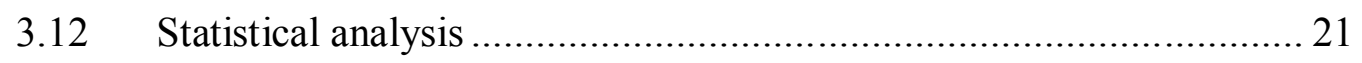

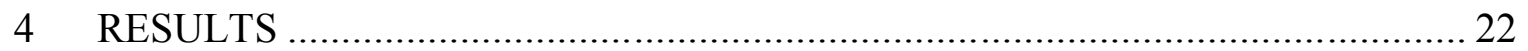

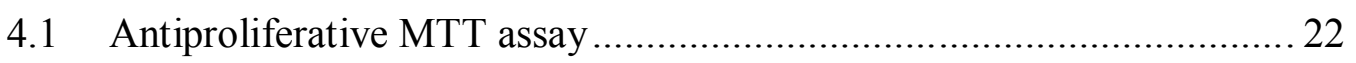

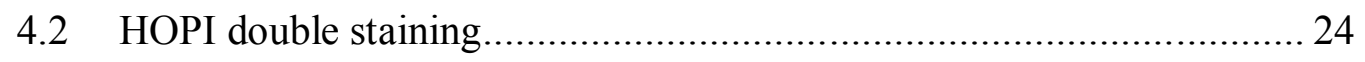


$4.3 \quad$ Cell cycle analysis by flow cytometry ........................................ 24

4.4 Determination of in situ caspase activity ....................................... 28

4.5 Distinction of G2 and M phases by specific flow cytometry................ 28

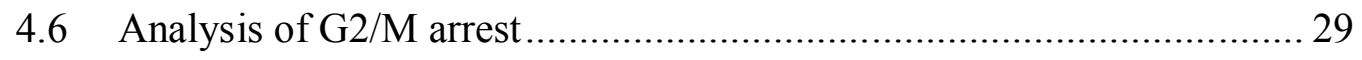

4.6.1 Reverse transcription PCR studies ........................................ 29

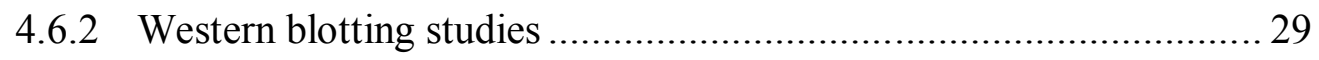

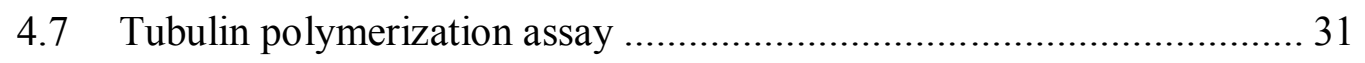

4.8 Analysis of cell migration using Wound healing assay ....................... 31

4.9 Analysis of cell invasion using Boyden chamber assay ...................... 33

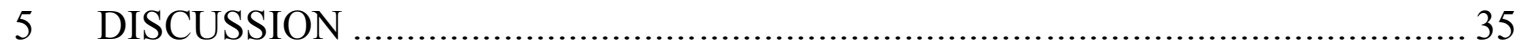

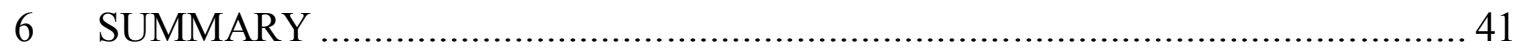

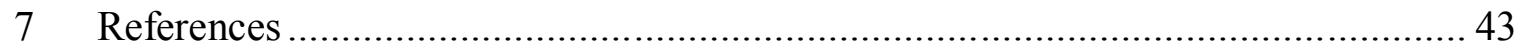

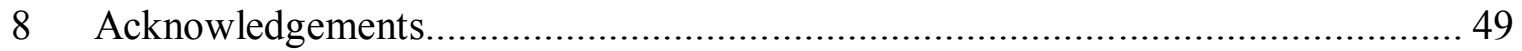




\section{SCIENTIFIC PUBLICATION RELATED TO THE SUBJECTS OF THE THESIS}

I. Bózsity N, Minorics R, Szabó J, Mernyák E, Schneider G, Wölfling J, Wang HC, Wu CC, Ocsovszki I, Zupkó I. Mechanism of antiproliferative action of a new dsecoestrone-triazole derivative in cervical cancer cells and its effect on cancer cell motility. The Journal of Steroid Biochemistry and Molecular Biology. 2017; $165: 247-257$

$\mathrm{IF}_{2016}: 4.561$

II. Szabó J, Jerkovics N, Schneider G, Wölfling J, Bózsity N, Minorics R, Zupkó I, Mernyák E. Synthesis and in vitro antiproliferative evaluation of C-13 epimers of triazolyl-D-secoestrone alcohols: The first potent $13 \alpha-\mathrm{D}$-secoestrone derivative. Molecules. 2016; 21:611

$\mathrm{IF}_{2016}: 2.861$

III. Minorics R, Bózsity N, Molnár J, Wölfling J, Mernyák E, Schneider G, Ocsovszki I, Zupkó I. A molecular understanding of D-homoestrone-induced G2/M cell cycle arrest in HeLa human cervical carcinoma cells. Journal of Cellular and Molecular Medicine. 2015; 19:2365-2374

$$
\mathrm{IF}_{2015}: 4.938
$$

IV. Mernyák E, Szabó J, Bacsa I, Huber J, Schneider G, Minorics R, Bózsity N, Zupkó I, Varga M, Bikádi Z, Hazai E, Wölfling J. Syntheses and antiproliferative effects of D-homo- and D-secoestrones. Steroids. 2014; 87:128-136

$$
\mathrm{IF}_{2014}: 2.639
$$

V. Minorics R, Bózsity N, Wölfling J, Mernyák E, Schneider G, Márki Á, Falkay G, Ocsovszki I, Zupkó I. Antiproliferative effect of normal and 13-epi-Dhomoestrone and their 3-methyl ethers on human reproductive cancer cell lines. The Journal of Steroid Biochemistry and Molecular Biology. 2012; 132:168-175

$\mathrm{IF}_{2012}: 3.984$ 


\section{Additional Publications}

1. Szabó J, Pataki Z, Wölfling J, Schneider G, Bózsity N, Minorics R, Zupkó I, Mernyák E. Synthesis and biological evaluation of 13alpha-estrone derivatives as potential antiproliferative agents. Steroids. 2016; 113:14-21

$$
\mathrm{IF}_{2016}: 2.282
$$

2. Schelz Z, Ocsovszki I, Bózsity N, Hohmann J, Zupkó I. Antiproliferative effects of various furanoacridones isolated from Ruta graveolens on human breast cancer cell lines. Anticancer Research. 2016; 36:2751-2758

$$
\mathrm{IF}_{2016}: 1.937
$$

3. Schneider G, Kiss A, Mernyák E, Benke Z, Wölfling J, Frank É, Bózsity N, Gyovai A, Minorics R, Zupkó I. Stereocontrolled synthesis of the four 16hydroxymethyl-19-nortestosterone isomers and their antiproliferative activities. Steroids. 2016; 105:113-120

$$
\mathrm{IF}_{2016}: 2.282
$$

4. Ványolós A, Kovács B, Bózsity N, Zupkó I, Hohmann J. Antiproliferative activity of some higher mushrooms from Hungary against human cancer cell lines. International Journal of Medicinal Mushrooms. 2015; 17:1145-1149

$\mathrm{IF}_{2015}: 1.357$ 


\section{LIST OF ABBREVIATION}

2-ME

CDK

Chk

D-HE

D-SE

D-SET

DISC

DIM

EMEM

EGF-R/erbB

FBS

GOG240

HOPI

HPV

MTT

Ras-Raf-MAPK

SEM

TGF $\alpha$ and $\beta$

VEGFR 2-methoxyestradiol

cyclin-dependent kinase

checkpoint kinase

D-homoestrone (test compound)

D-secoestrone (test compound)

D-secoestrone-triazol (test compound)

death-inducing signaling complex

D-secoestrone and 13-epiestrone linked dimer (test compound)

Eagle's Minimum Essential Medium

epidermal growth factor receptor

Fetal Bovine Serum

phase III clinical trial by the Gynecologic Oncology Group (GOG)

Hoechst 33258 - propidium iodide

Human papillomavirus

3-(4,5-dimethylthiazol-2-yl)-2,5-diphenyltetrazolium bromide

mitogen-activated protein kinase signal transduction cascade

standard error of the mean

tumor growth factor $\alpha$ and $\beta$

vascular endothelial growth factor receptor 


\section{INTRODUCTION}

\subsection{Epidemiology of cervical cancer}

Besides cardiovascular diseases, cancer is the second leading cause of death worldwide. In 2012, around 8.2 million cancer deaths occurred and 14.1 million new cancer cases were detected. In women, cervical cancer is the fourth most frequently diagnosed cancer accounting for 527,600 new cases and the fourth leading cause of death with 265,700 deaths, worldwide ${ }^{1}$. European countries have a similar trend as the global cancer statistics, cervical cancer is the fifth most common cancer in Europe, accounting for 58,300 new cases, and 13,400 cervical cancer deaths. 38,800 of all new cervical cancer cases occur in Central European countries, referring that, cervical cancer is the fourth most frequently diagnosed tumor type in Central Europe also in $2012^{2}$.

Even cancer is a non-communicative disease, infectious agents have crucial roles in the pathogenesis of various cancer cases. Approximately $12 \%$ of all cancers are caused by oncogenic microbes, such as Helicobacter pylori in gastric carcinomas, hepatitis B and $\mathrm{C}$ viruses in hepatic carcinomas, Epstein-Barr virus in Burkitt lymphoma and human papilloma virus (HPV) infection is predominantly related with cervical cancer ${ }^{3,4}$. Epidemiological studies indicate that more than 600 million people are infected with HPV worldwide, and around 5\% of all cancer cases are associated with HPV including almost all cases of cervical, majority of anal, vaginal and increasing number of oral cavity and pharyngeal cancers ${ }^{5}$. It has been proven that around 18 variants of HPV are associated with carcinogenesis, of which HPV-18 and -16 are responsible for approximately $50 \%$ and $20 \%$ of cervical cancerous cases, respectively ${ }^{6,7}$. During the last few years vaccination and screening methods became widely available in developed countries, therefore the number of death cases have decreased. At the same time in less developed countries cervical cancer is still the second most commonly diagnosed malignancy, and nearly $90 \%$ of cervical cancer deaths occur in those countries ${ }^{1,8}$. Moreover vaccination is recommended under the age of 25 or before the initiation of sexual activity (its effectiveness is the highest before any exposure to HPV infection) $)^{9,10}$, therefore women over 25 years or influenced by antivaccination groups in developed countries are still compromised.

It has emerged that vaccination does not have any therapeutic effect against already-established infections or in asymptomatic carriers ${ }^{11}$. The traditional therapeutic 
interventions are the radical surgery, brachytherapy, platinum-based, taxol-use and targeted chemotherapy (bevacizumab), moreover in most cases clinicians use the combination of these ${ }^{12,13}$. Despite the combinations remarkable therapeutic difficulties, such as the adverse effects including haematological and gastrointestinal toxicities or the lack of a significant improvement in survival rate have been reported. The GOG240 trial revealed that the humanized anti-VEGF monoclonal antibody bevacizumab improved the median overall survival with 3.7 months of the patients with recurrent, persistent, or metastatic cervical cancer, although more severe toxicity profiles (hypotension, thromboembolic events and gastrointestinal fistulas) were reported in the addition of bevacizumab than the traditional combined chemotherapy ${ }^{14}$.

Statistical data suggest that this special type of malignant cervical lesions even if they are diagnosed in early stage need rapid and aggressive treatment utilizing novel more potent anticancer agents with a more tolerable side-effect profile.

\subsection{General principles of tumor formation and viral oncogenesis}

Normally, the numbers of the different types of cells in an organism are constant, thanks to the precise regulation of cell division; meanwhile if the regulating signals are faulty or missing cells may start uncontrolled grow and multiply. Carcinogenesis is a complex process including multiple changes in cell growth, differentiation and behavior. Cancer can be characterized as a disease involving dynamic changes in the gene expression of the affected cells, which reflects previous genetic or epigenetic deviations. This alteration of the critical genes is the initial step during the tumor formation, which can trigger different cellular mechanisms of tumorigenesis. In 2000 Hanahan and Weinberg summarized six essential alterations in cell physiology which may lead to the hallmarks of malignant tumorigenesis, including self-sufficiency in growth signals, insensitivity of growth inhibitory signals, evasion of apoptosis, limitless replicative potential, sustained angiogenesis and tissue invasion and metastasis ${ }^{15}$. After a decade they extended their hypothesis with better understood, highly important details, such as the role of the "tumor microenvironment", defined two new emerging hallmarks: the immunoevasion (how cancer cells can avoid immune distraction) and the reprogramming of energy metabolism of cells (to fuel cell growth and division); and two new enabling characteristics: genome instability, which generates random mutations and inflammatory state of premalignant lesions ${ }^{16}$. Floor et al. completed that hallmarks with an additional 
characteristics: the loss of differentiation, which is an essential difference between benign and malignant tumors ${ }^{17}$.

Normally, cells cannot proliferate without external growth signals, such as mitogenic growth factors or integrins. Contrarily, tumor cells may mimic these normal growth signals by producing growth factors (e.g. platelet derived growth factor, TGF- $\alpha$ ) to establish autocrine stimulation, changing the transcellular transducers mostly by structural modification or overexpression of the intracellular part of the growth factor receptors, which can elicit ligand independent signals (e.g. EGF-R/erbB). Furthermore, cancer cells are able to imitate progrowth signals through integrin receptors mediated signaling, as well as they can initiate autonomous cytoplasmic circuitry (e.g. Ras-RafMAPK cascade) releasing the flux of mitogenic signals without the previously mentioned extracellular pathways. Avoidance of the antigrowth signals causes permanent cell cycle activation, mostly by losing retinoblastoma associated protein regulation as a consequence of mutation of retinoblastoma genes or suppressing upstream regulators (e.g. TGF- $\beta$, CDK4). Besides these two capabilities cancer cells may successfully evade programmed cell death by loss of proapoptotic regulators (e.g. p53), by increased expression of antiapoptotic regulators (e.g. Bcl-2) or downregulating proapoptotic factors (e.g. Bax). Tumor cells are also able to turn off their intrinsic multiplication limit (DNA shortening), resulting immortality by activation of telomerases at a constant level ${ }^{15,16}$.

Sustained angiogenesis covers the nutrient requirement of the growing tumor by the tumor-associated neovascularization due to activation of proangiogenetic factors (e.g. vascular endothelial growth factor-A) and inhibition of angiogenesis inhibitors (e.g thrombospondin-1). Metastases are distant settlements of tumor cells representing a major prognostic factor of malignancy. Increased migratory and invasion capacity is required to form metastasis, and mainly it develops as a consequence of the modified connection state with other cells and extracellular matrix called epithelial mesenchymal transition through cadherins ${ }^{15,16}$.

Generally, oncoviruses are not sufficient but necessary inducers of cancer development and characterized by a persistent infection and the onset of the malignant lesion occurs years after the primary infection. Viral-induced oncogenesis is a multistep process: viruses disrupt the homeostasis of the infected cells and trigger cellular changes leading to malignity. Oncoviruses have some general mechanisms such as signaling mimicry (virus encoded proteins, which subvert the host-signaling mechanisms), changed 
DNA damage response (host cells acquire genetic instability and help viral replication) and chronic inflammatory response $e^{4,5}$.

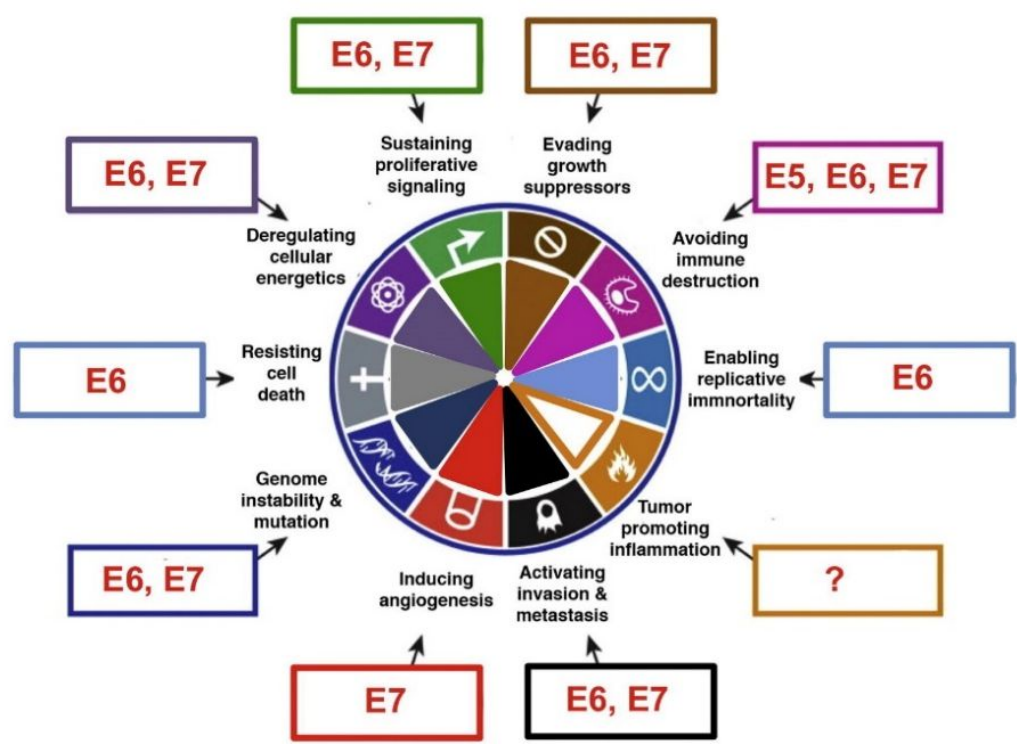

Figure 1. HPV oncoproteins and their target mechanism in cancer hallmarks ${ }^{4}$.

Already more than 150 HPV genotype have been described and some of them could be involved in oncogenesis depending on the immune state of the host and the type of the virus. The "high-risk" viruses compose of a small group, closely related to mucosal epithelial carcinomas which establish integrated HPV sequences in the host cells, encoding potent oncoproteins resulting changes from normal functions into premalignant condition. E5, E6 and E7 are the most important oncoproteins encoded by HPVs and expressed consistently after genome integration. There is a large volume of published studies describing the role of these oncoproteins, summarized in Figure 1. It is well-known, that, HPV E6 and E7 proteins induce genome instability and mutations by p53 inactivation and aberrant centrosome synthesis respectively, leading to multipolar mitosis, one of the main features of high-risk HPV-associated lesions. E7 protein interacts with retinoblastoma tumor suppressor, causing persistent $\mathrm{S}$ phase activation and uncontrolled cell cycle repeat. E7 is also connected with angiogenesis and affects the cell metabolism by shifting the normal phosphorylation-based metabolism to aerobic fermentation (Warburg effect). Oncoprotein E6 has key role in immortalization of human epithelial cells by stimulation of telomerase expression and activity. Both E6 and E7 provoke cell migration and invasion contributing to epithelial to mesenchymal transition, and also inhibit IFN signaling, which supports immunoevasion. HPV E5 is another important factor in the process of avoiding immune destruction by downregulation of MHC I ${ }^{4,5}$. 


\subsection{The role of estrogens and estrogen-related compounds in tumor formation}

Estrogens are traditionally regarded as crucial factors of the reproductive systems, including the regulation of growth and differentiation ${ }^{18}$, as well as it is well known that $17 \beta$-estradiol generally increases the proliferation of its target cells not only in the reproductive system but also in gynecological tumors by stimulating RNA synthesis of numerous growth factors, regulating proteins and proto-oncogenes ${ }^{19}$. Estrogens initiate the transcription of targeted genes by binding specifically to their nuclear receptors. Furthermore, estrogens may induce different signaling pathways that are mediated by PI3K-AKT and MAPK-ERK signals regulating crucial cell responses such as proliferation, invasion, survival, migration, apoptosis, and even metastasis through nongenomic signaling ${ }^{20}$.

In recent years, an increasing body of evidence indicated that structural modifications of $17 \beta$-estradiol may lead to estrone analogues with antiproliferative activity. The A-ring-modified 2-methoxyestradiol (2-ME) was one of the first discovered metabolites without any hormonal activity, but exerting antiproliferative actions against several cancerous cell lines ${ }^{21-23}$ owing to its apoptosis-activating, microtubule-disrupting, antimigratory and antiangiogenic effects ${ }^{24}$. On the basis of these findings many new derivatives with anticancer properties have been synthesized and investigated. The majority of published studies have focused on substitutions in multiple positions of the steroid structure or ring modifications. Among this series of analogues, same or higher antiproliferative activities compared to that of 2-ME have been determined mostly on breast cancer cell lines. Results indicated that the investigated 2-ME derivatives were able to directly increase tubulin depolymerization similar to 2-ME. In spite of the substantial interest in the anticancer action of 2-ME, its experimental results against HeLa cells are limited to one single publication ${ }^{25}$. Additionally, three sulphamoylated analogues were reported to induce extrinsic and intrinsic apoptotic pathways followed by autophagy in HeLa cells. Moreover, it was revealed that similarly to 2-ME, the sulphamoylated analogues also increased tubulin depolymerization both in cell-free system and in living cells.

The most frequent positions for substitution of the sterane skeleton are C-2, C-3 and $\mathrm{C}-17$. Based on previous observations that several nonsteroidal triazole derivatives have antiproliferative and proapoptotic properties, triazole ring can be regarded as a 
pharmacophore when built onto a steroid or other types of skeletons ${ }^{26,27}$. Moreover, several lines of evidence suggest that steroidal 16 or 17-triazoles exert potent growth-inhibitory effects ${ }^{28,29}$. Molnar et al. examined the antiproliferative actions of $16 \alpha-$ triazolyl derivatives on human adherent cell lines, and found that these compounds may activate the intrinsic pathway of apoptosis and induce cell cycle blockade at G2/M phase $^{29}$. Furthermore, a recent study has shown that triazole substitution in position C-3 dramatically enhance the antiproliferative activity of D-secooxime derivatives ${ }^{30}$.

Previous research has established that core modifications, such as expansion or opening of D-ring may lead to homo- and secoestrones without any estrogenic activity $^{31-33}$. This kind of structural modifications can result in further promising estronebased group of novel compounds which are potential candidates for anticancer investigations. 


\section{SPECIFIC AIMS}

The aim of the present study was to characterize the antiproliferative mechanism of action of recently synthesized D-ring modified (D-homo- or D-seco-) estrogen analogues on cervical cancer cell lines. The specific aims of the performed investigations were the followings:

Antiproliferative screening of the newly synthesized estrane-based derivatives on human reproductive cancer cells, in vitro. Investigation of the tumor selectivity of the most potent compounds, using non-cancerous cell lines.

$>$ Comparing the activity of the most effective molecules on different HPV status cervical cell lines, considering by their different structure

$>$ Investigating the proapoptotic properties of the most effective compounds, using fluorescent HOPI double staining, determination of caspase-3 activity and cell cycle analysis.

Characterization of the alterations in cell cycle progression by flow cytometry, PCR technique, Western blot and tubulin polymerization analysis.

Description of their effect on cell migration and invasion to reveal their influence on cancer cells motility. 


\section{MATERIALS AND METHODS}

\subsection{Chemicals}

D-ring modified estrogen analogues, D-homo and D-secosteroids and their dimer derivatives were synthesized in the Institute of Organic Chemistry (University of Szeged, Szeged) as described previously ${ }^{34-36}$. The chemical structure of the four most potent and widely investigated compounds of this study are presented in Figure 2. All other chemicals and kits, if otherwise not specified, were purchase from Sigma Aldrich Ltd. (Budapest, Hungary).<smiles>C[C@]12CC[C@H]3CC(O)=CC=C3[C@@H]1CC[C@@H]1CCCC(=O)[C@@H]12</smiles><smiles></smiles><smiles>CCCC1C2CCc3cc(OCc4cn(C5CC6C7CCc8cc(OCc9ccccc9)ccc8C7CC[C@]6(C)[C@H]5O)nn4)ccc3C2CCC1(C)CO</smiles>

Figure 2. Chemical structure of the selected compounds: A: D-homoestrone, D-HE (3Hydroxy-D-homoestra-1,3,5(10)-trien-17a-one) B: D-secoestrone, D-SE (3-Benzyloxy-

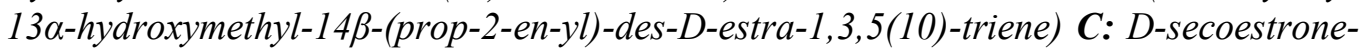
triazole, D-SET (3-[(1-benzyl-1H-1,2,3-triazol-4-yl)methoxy]-13 $\alpha$-hydroxymethyl-14 $\beta$ propyl-des-D-estra-1,3,5(10)-triene) D: D-secoestrone and 13-epiestrone linked dimer, DIM (3-[\{1-(3-benzyloxy-17 $\alpha$-hydroxy-13 $\alpha$-estra-1,3,5(10)-trien-16 $\beta$-yl)-1H1,2,3-triazol-4-yl\}methoxy]-13 $\alpha$-hydroxymethyl-14 $\beta$-propyl-des-D-estra1,3,5(10)-triene). 


\subsection{Cell lines and culturing conditions}

For the antiproliferative screening, a panel of human adherent gynecological cancer cell lines was used. The human breast cancer cell lines (MCF-7, MDA-MB-231, MDA-MB-361 and T47D), endometrial adenocarcinoma (Ishikawa), ovarian carcinoma (A2780), skin epidermoid carcinoma (A431), HPV 18+ cervical adenocarcinoma (HeLa) and non-cancerous MRC-5 cell lines were purchased from ECACC (European Collection of Cell Cultures, Salisbury, UK ), while SiHa (HPV 16+ squamous cell carcinoma) and C-33 A (HPV - epithelial carcinoma) were purchased from ATCC (American Tissue Culture Collection, LGC Standards GmbH, Wesel, Germany). Cells were maintained in Eagle's Minimum Essential Medium (EMEM) supplemented with 10\% heat-inactivated fetal calf serum (FCS), 1\% non-essential aminoacids (NEAA), and 1\% antibioticantimycotic mixture (AAM, penicillin-streptomycin). All media and supplements were obtained from Lonza Group Ltd. (Basel, Switzerland). The cells were maintained at $37{ }^{\circ} \mathrm{C}$ in humidified atmosphere containing $5 \% \mathrm{CO}_{2}$.

\subsection{Antiproliferative MTT assay}

The growth-inhibitory effect of the compounds was determined by standard MTT (3-(4,5-dimethylthiazol-2-yl)-2,5-diphenyltetrazolium bromide) dye uptake method. Experiments were carried out in the same way as in previously described ${ }^{36}$. Briefly, cells were seeded onto 96-well plates at a density of 5,000 cells/well, except for C-33 A and MDA-MB-361, which were seeded at 10,000/well. After overnight standing, new medium, containing the tested compounds at 10 and $30 \mu \mathrm{M}$, were added for the antiproliferative screening and increasing concentration of the test compounds (0.1-30.0 $\mu \mathrm{M})$ were added for concentration-response curves. After incubation for $72 \mathrm{~h}$ under a cell culturing conditions, $5 \mathrm{mg} / \mathrm{ml}$ MTT solution was added for another $4 \mathrm{~h}$. The precipitated formazan crystals were solubilized in dimethyl sulfoxide and the absorbance was measured at $545 \mathrm{~nm}$ with an ELISA microplate reader (Stat Fax 2100, Awarness Technology INC, Palm City, FL, USA). Wells with untreated cells were utilized as control $^{37}$, cisplatin was used as a positive control in the same concentration range as the test compounds. Sigmoidal concentration-response curves were fitted to the determined points, and $\mathrm{IC}_{50}$ values were calculated by means of GraphPad Prism 5.01 (GraphPad Software, San Diego, CA, USA). 


\subsection{Hoechst 33258 - propidium iodide (HOPI) double staining}

HOPI staining was performed as described earlier ${ }^{38}$. HeLa, C-33 A and SiHa cell lines were seeded in 96-well plates, at 3,000-5,000 cells/well. After incubation for $24 \mathrm{~h}$ with the test compounds Hoechst $33258(\mathrm{HO})$ and propidium iodide (PI) were added directly to the cells $5 \mu \mathrm{g} / \mathrm{ml}$ and $3 \mu \mathrm{g} / \mathrm{ml}$ final concentrations in EMEM, respectively. After $60 \mathrm{~min}$ incubation at $37^{\circ} \mathrm{C}$ and $5 \% \mathrm{CO}_{2}$ cells were examined under a Nikon ECLIPSE TS100 fluorescence microscope (Nikon Instruments Europe B.V., Amstelveen, The Netherlands) equipped with appropriate filters for HO (excitation: 360/40 nm bandpass filter, emission: 460/50 $\mathrm{nm}$ bandpass filter and $400 \mathrm{~nm}$ dichromatic mirror) and PI (excitation: 500/20 nm bandpass filter, emission: $520 \mathrm{~nm}$ longpass filter and $515 \mathrm{~nm}$ dichromatic mirror). This method allows a distinction between early apoptosis and late apoptosis (secondary necrosis) by the nuclear morphology and membrane integrity of the cells. To detect the form of cell death two separate pictures from the same field were taken. Nuclei of intact cells are stained homogeneously blue, while under the apoptotic progress bright chromatin condensation and nuclear fragmentation can be observed. PI uptake indicates loss of membrane integrity which can be explained by late-apoptosis or necrosis.

\subsection{Cell cycle analysis by flow cytometry}

To determine the cellular DNA content of the treated cells flow cytometric analysis was performed. HeLa, C-33 A and SiHa cells were seeded into 6-well plates at a density of 250,000-400,000 cells/well. 24 or $48 \mathrm{~h}$ after treatment cells were harvested with trypsin and centrifuged at $1500 \mathrm{rpm}$ for $10 \mathrm{~min}$. After a washing step, the cells were fixed in $1 \mathrm{ml}$ ice-cold $70 \%$ ethanol for $30 \mathrm{~min}$. Samples were stained with $0.1 \mathrm{mg} / \mathrm{ml} \mathrm{PI}$ dye solution containing $0.02 \mathrm{mg} / \mathrm{ml}$ RNAse A for $60 \mathrm{~min}$ in the dark at room temperature. Cells were analysed by a Partec CyFlow instrument (Partec GmbH, Münster, Germany). In each analysis, 20,000 events were recorded, and the percentages of the cells in the different cell cycle phases (subG1, G1, S and G2/M) were determined by using ModFit LT 3.3.11 Software (Verity Software House, Topsham, ME, USA). The subG1 fraction was regarded as the apoptotic cell population ${ }^{39}$. 


\subsection{Determination of in situ caspase activity}

Caspases are the most crucial enzymes of the apoptotic machinery. To analyze the effect of the selected compounds on caspase-3 activity, a commercially available colorimetric assay was performed. $10^{7}$ cells were seeded in tissue culture flasks. After 24 or 48 hours incubation, cells were counted, centrifuged and washed with PBS. The cells were resuspended in lysis buffer and incubated on ice for $20 \mathrm{~min}$. The lysates were centrifuged and the supernatant were used. The protein concentrations of the lysates were measured with the Pierce BCA Protein Assay Kit (Pierce Biotechnology, Rockford, USA) and equal protein amounts were used for the measurement. In accordance with the manufacturer's protocol, equal portions of treated and untreated cell lysates were incubated with selective caspase-3 substrates (acetyl-Asp-Glu-Val-Asp- $p$-nitroanilid) in a final volume of $100 \mu \mathrm{l}$ in assay buffer, in 96-well plates. After an overnight incubation at $37^{\circ} \mathrm{C}$ the absorbance of $p$-nitroaniline was measured at $405 \mathrm{~nm}$ with microplate reader. Comparison of the absorbance of $p$-nitroaniline from the treated and untreated samples allowed determination of the fold increase of caspase activity.

\subsection{Distinction of $G 2$ and M phases by specific flow cytometry}

To separate $\mathrm{G} 2$ and $\mathrm{M}$ populations $\mathrm{M}$ phase specific immunocytochemical flow cytometry was applied. The phosphorylation of histone H3 at Ser10 correlates with the G2 to $M$ phase transition. The presence of this phosphorylation is a prerequisite for chromatin condensation, it proceeds under the metaphase whereas the dephosphorylation occurs rapidly at the end of mitosis. Therefore, the antibody is a reliable marker to identify cells specifically in M phase ${ }^{40}$. HeLa cells were plated into 6-well plates and allowed to proliferate for 48 h. 24 hours after the treatment with $1.0 \mu \mathrm{M}$ test compound and $5 \mathrm{nM}$ paclitaxel as a positive control ${ }^{41}$, cells were washed and harvested as mentioned above. Cells were resuspended with PBS and a commercially available FlowCellect ${ }^{\mathrm{TM}}$ Bivariate Cell Cycle Kit for G2/M Analysis (Millipore Co, Billerica, MA, USA) was used. Briefly, cells were fixed for $20 \mathrm{~min}$ at $4{ }^{\circ} \mathrm{C}$ and permeabilized for $5 \mathrm{~min}$ at $4{ }^{\circ} \mathrm{C}$. Cells were stained with anti-phospho-Histone H3 (Ser10) antibody conjugated with Alexa Fluor 488 at $4{ }^{\circ} \mathrm{C}$, for $1 \mathrm{~h}$ in the dark. Freshly prepared PI/RNase solution was added and incubated in the dark for $30 \mathrm{~min}$ at room temperature. Samples were analysed 
on the Partec CyFlow instrument. In each analysis, 20,000 events were recorded, and the data were evaluated using Flowing Software 2.5.1 (Cell Imaging Core, Turku Centre for Biotechnology, Turku, Finland).

\subsection{Analysis of G2/M arrest}

\subsubsection{Reverse transcription PCR (RT-PCR) studies}

The transition from the $\mathrm{G} 2$ to the $\mathrm{M}$ phase of the cell cycle is rigorously regulated by cyclin-dependent kinase 1 (CDK1) and cyclins. The expressions of these regulating factors at mRNA level were determined by RT-PCR in HeLa cells. After a $48 \mathrm{~h}$ incubation with the appropriate test compound total RNA was isolated from the cells $\left(5 \times 10^{5}\right)$ using TRIzol Reagent in accordance with the instructions of the manufacturer (Life Technologies, Paisley, Scotland, UK). The RNA concentrations of the samples were determined from their absorbances at $260 \mathrm{~nm}$. cDNA was generated from the prepared total RNA solution. Briefly, the RNA $(0.5 \mu \mathrm{g})$ was mixed with DNase- and RNase-free distilled water and $20 \mu \mathrm{M}$ oligo(dT) (Promega, Madison, WI, USA) in a final reaction volume of $10 \mu \mathrm{L}$ and was incubated at $70{ }^{\circ} \mathrm{C}$ for $5 \mathrm{~min}$. After the mixture had been cooled to $4{ }^{\circ} \mathrm{C}, 20 \mathrm{U}$ RNase inhibitor (Fermentas ${ }^{\mathrm{TM}}$, Thermo Fisher Scientific Inc., Waltham, MA, USA), $20 \mathrm{UMMLV}$ reverse transcriptase (Promega, Madison, WI, USA), $200 \mu \mathrm{M}$ dNTP (Life Technologies, Paisley, Scotland, UK) in $50 \mathrm{mM}$ Tris-HCl, pH 8.3, $75 \mathrm{mM} \mathrm{KCl}$, and $5 \mathrm{mM} \mathrm{MgCl} 2$ were added in a final reaction volume of $10 \mu \mathrm{L}$. The mixture was incubated at $37^{\circ} \mathrm{C}$ for $60 \mathrm{~min}$. The PCR was carried out with $5 \mu \mathrm{L}$ cDNA, $12.5 \mu \mathrm{L}$ AccuStart GelTrack PCR SuperMix (Quanta Biosciences Inc., Gaithersburg, $\mathrm{MD}, \mathrm{USA}), 2 \mu \mathrm{L} 20 \mathrm{pM}$ sense and antisense primer of $\mathrm{CDK} 1^{42}$, cyclin $\mathrm{B} 1$, cyclin $\mathrm{B} 2^{43}$, $\mathrm{Cdc} 25 \mathrm{~B}^{44}, \mathrm{Cdc} 25 \mathrm{C}^{45}$ and $3.5 \mu \mathrm{L}$ DNase- and RNase-free distilled water. As internal control human glyceraldehyde 3-phosphate dehydrogenase (hGAPDH) primers were used in all samples ${ }^{46}$. The reaction was performed with an ESCO SWIFT MAXI thermal cycler (Esco Technologies Inc, Philadelphia, PA, USA) and the products were separated on $2 \%$ agarose gels, stained with ethidium bromide and photographed under a UV transilluminator. Semiquantitative analysis was performed by densitometric scanning of the gel with Kodak IMAGE STATION 2000R (Eastman Kodak Co., Rochester, NY, USA). 


\subsubsection{Western blotting studies}

To investigate the downstream events of CDK1-cyclin B complex phosphorylated and total stathmin protein expression was determined by western blot.

HeLa cells were seeded into $60-\mathrm{mm}$ dishes at a density of $2 \times 10^{5}$ cells $/ \mathrm{mL}$ and treated with the test compound for 48 hours. Whole-cell extracts were prepared by adding lysis buffer (50 mM Tris, $5 \mathrm{mM}$ EDTA, $150 \mathrm{mM} \mathrm{NaCl}, 1 \% \mathrm{NP}-40,0.5 \%$ deoxycholic acid, $1 \mathrm{mM}$ sodium orthovanadate, $100 \mu \mathrm{g} / \mathrm{mL}$ PMSF and protease inhibitors $)^{47} .10 \mu \mathrm{g}$ of protein per well was subjected to electrophoresis on 4-12\% NuPAGE Bis-Tris Gel in XCell SureLock Mini-Cell Units (Invitrogen, Carlsbad, CA, USA). Proteins were transferred from gels to nitrocellulose membranes, using the iBlot Gel Transfer System (Invitrogen, Carlsbad, CA, USA). Antibody binding was detected with the WesternBreeze Chemiluminescent Western blot immunodetection kit (Invitrogen, Carlsbad, CA, USA). The blots were incubated on a shaker with stathmin (Op18), phosphorylated stathmin (pOp18) and $\beta$-actin polyclonal rabbit antibody (Santa Cruz Biotechnology, Santa Cruz, CA, USA) 1:200 in the blocking buffer. Semiquantitative analysis was performed by densitometric scanning of the blot with Kodak IMAGE STATION 2000R (Eastman Kodak Co., Rochester, NY, USA).

\subsection{Tubulin polymerization assay}

The cell-independent direct effect of the test compound on tubulin polymerization was tested in vitro, using a commercially available Tubulin Polymerization Assay Kit (Cytoskeleton Inc., Denver, CO, USA), according to the manufacturer's recommendation. Briefly, $10 \mu 1$ of test compounds, paclitaxel, or general tubulin buffer (as positive and negative controls) were placed on prewarmed UV transparent microplate. $100 \mu \mathrm{l}$ $3.0 \mathrm{mg} / \mathrm{ml}$ tubulin in $80 \mathrm{mM}$ PIPES pH 6.9, $2 \mathrm{mM} \mathrm{MgCl}_{2}, 0.5 \mathrm{mM}$ EGTA, $1 \mathrm{mM}$ GTP, $10.2 \%$ glycerol was added to each sample, and the measurement was started immediately in a prewarmed UV spectrophotometer (SpectroStarNano, BMG Labtech, Ortenberg, Germany). 50 min kinetic reaction was recorded, to determine the absorbance of tubulin solution at $340 \mathrm{~nm}$, per minute. For the statistical analysis maximum rate $\left(\mathrm{V}_{\max }\right.$, $\Delta$ absorbance/min) was calculated from the kinetic curve. $V_{\max }$ is the highest difference of the absorbance of two successive time points at the kinetic curve. 


\subsection{Analysis of cell migration using wound healing assay}

To analyze the migratory capacity of HeLa cells wound healing assay was used. The assay was performed using specific wound healing assay chambers (ibidi $\mathrm{GmbH}$, Martinsried, Gemany). HeLa cells were trypsinised and 35,000 cells (100 $\mu \mathrm{l}$ of 350,000 cells $/ \mathrm{ml}$ cell suspension) were seeded into each chambers of the inserts ${ }^{48}$. After an overnight incubation for appropriate cell attachments at $37{ }^{\circ} \mathrm{C}$ and $5 \% \mathrm{CO}_{2}$ the culture insert were removed. Washing step with PBS were used to remove inappropriately attached cells and debris. Cells were treated with increasing concentration of the test compounds in medium containing $1 \%$ FBS for 24 hours. Migration of the cells into the wound site was visualized with phase-contrast inverted microscope (Axiovert 40, Zeiss, Thornwood, NY, US). Images were recorded with CCD camera to asses wound closure. The rate of migration was calculated as the ratio of wound closure in treated samples after $24 \mathrm{~h}$ and $0 \mathrm{~h}$ compared to the same ratio obtained from untreated control samples.

\subsection{Analysis of cell invasion using Boyden chamber assay}

The invasion ability of HeLa cells was assessed using the BD BioCoat Matrigel Invasion Chamber with 8 micron pore size PET membrane containing a thin layer of Matrigel Basement Matrix (BD Biosciences, Bedford, MA, USA) according to the instruction of the manufacturer. Briefly, HeLa cells were trypsinised, washed and resuspended in serum free medium. A total of 50,000 cells were seeded into each top insert with or without test compounds. $10 \%$ FBS containing medium was filled in the bottom well as chemoattractant. After 24 hours incubation at $37^{\circ} \mathrm{C}$ and $5 \% \mathrm{CO}_{2}$, the culture insert was removed and the non-invading cells were eliminated by scrubbing with cotton swab. The inserts were washed with PBS, fixed with cold methanol and stained with crystal violet solution. The invading stained cells were counted under a phasecontrast inverted microscope; a minimum of 8 fields per insert were counted. The rate of invasion was calculated from the invaded cell number of treated and untreated control conditions. 


\subsection{Statistical analysis}

For statistical evaluation of the experimental data GraphPad Prism version 5.01 for Windows (GraphPad Software, San Diego, CA, USA) software were used. The statistical significance was assessed by one-way ANOVA with Dunett post test for comparison of multiple groups. 


\section{RESULTS}

\subsection{Antiproliferative MTT assay}

As a first phase of the work 46 estrane-based novel compounds were screened for antiproliferative effects. 4 of them were the normal and 13-epi-D-homoestrone and their 3-methyl ethers. Only D-homoestrone (D-HE) was effective against HeLa without

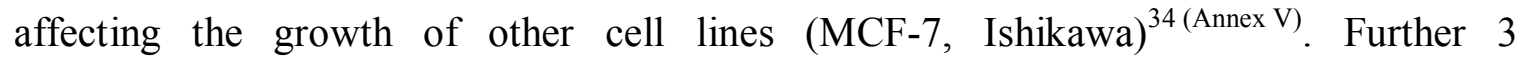
D-homoestrone derivatives were investigated derived from the molecule D-homoestrone, differing of their functional group on $\mathrm{C} 3$ and $\mathrm{C} 17 \mathrm{a}$. 17aß-D-homoestradiol behaved similarly to D-homoestrone, it has a selective antiproliferative effect on HeLa cells with micromolar $\mathrm{IC}_{50}$ value. The 3-benzyl ether of the $\alpha, \beta$-unsaturated ketone was not active, while the 3-benzyl ether of 17aß-D-homoestradiol inhibited the growth of the investigated cell lines (HeLa, MCF-7, A2780, A431), and it has relative selective effect on A2780 ovarian cancer cell line. Eight additional D-homosteroids with 16-halomethyl substitution were tested, but none of them influenced the proliferation of the used cell lines (HeLa, MCF-7, A2780, A431 and Ishikawa) 35 (Annex IV).

The investigation of 8 newly synthetized D-secoestrone compounds on 5 cell lines (HeLa, MCF-7, A2780, A431 and Ishikawa) revealed that 3-benzyloxy-13 $\alpha$ hydroxymethyl-14 $\beta$-(prop-2-en-yl)-des-D-estra-1,3,5(10)-triene (D-SE), the initial secoalcohol and their 17-acetoxy-3-benzyl ether derivatives have significant antiproliferative property against all the investigated cell lines (HeLa, C-33 A, SiHa, MCF-7, A2780, A431, Ishikawa, and T47D, MDA-MB-231, MDA-MB-361), while the further tested D-secosteroids did not show any growth inhibiting activity ${ }^{35}$ (Annex IV). Based on the results of D-SE 5 new secoalcohol derivatives were synthetized, but just one of them, the 3-propargyl ether of $13 \beta$-secoalcohol inhibited substantially the cell growth of HeLa, SiHa and MDA-MB-231 cells at $30 \mu \mathrm{M}$ concentration. We have also investigated 10 compounds with 3-triazol substitution of D-secoalcohol against 8 gynecological cell lines (cervical: HeLa, C-33 A, SiHa, ovarian: A2780, breast: MCF-7, T47D, MDA-MB-231 and MDA-MB-361). It was found, that almost all of them have more potent antiproliferative effect than above-mentioned secoalcohols. Moreover, the most potent derivative was the D-secoestrone-triazole (D-SET) bearing unsubstituted N-benzyl group, exerting micromolar $\mathrm{IC}_{50}$ values against two cervical (HeLa, C-33 A) and an ovarian (A2780) cancer cell lines. Concerning the other tested triazole-containing 
compounds the $13 \beta$-epimers exerted higher inhibition than their $13 \alpha$ counterparts and presence of $p$-alkyl or -nitro substituent on the $N$-benzyl ring of the triazoles appeared to be disadvantageous ${ }^{36}$ (Annex II).

Based on previous results we started to investigate the antiproliferative activity of 8 newly synthesized D-secoestrone and 13-epiestrone linked dimer compounds on 9 different cell lines (HeLa, C-33 A, SiHa, MCF-7, T47D, MDA-MB-231, MDA-MB-361, A2780, A431). Just one of them, the dimer consisting of the 3-

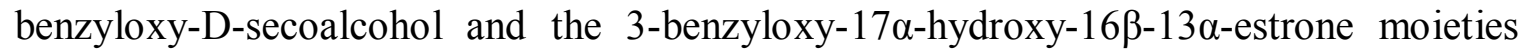
linked by a triazole ring (DIM) has substantial growth inhibitory effect on all of the tested cell lines.

The four most potent compounds from the previously mentioned estrogen analogue library: D-homoestrone (D-HE). D-secoestrone (D-SE), D-secoestrone-triazol (D-SET) and the D-secoestrone and 13-epiestrone linked dimer (DIM) were chosen for detailed investigation. We have found that the four estrogen analogues have highly different antiproliferative action against the cervical cell lines with various pathological backgrounds. The $\mathrm{IC}_{50}$ values of the four derivatives on the three different HPV status cervical carcinoma cell lines are presented in Table 1. Results show that DIM has a potent effect on all of the three cell lines with a micromolar concentration independently from their HPV status $\left(\mathrm{IC}_{50}{ }^{\mathrm{HeLa}}=1.7 \mu \mathrm{M}, \mathrm{IC}_{50}{ }^{\mathrm{SiHa}}=0.96 \mu \mathrm{M}\right.$ and $\left.\mathrm{IC}_{50}{ }^{\mathrm{C}-33} \mathrm{~A}=2.9 \mu \mathrm{M}\right) ; \mathrm{D}-\mathrm{SE}$ also can effect either of three cell lines, but with a lower efficiency $\left(\mathrm{IC}_{50}{ }^{\mathrm{HeLa}}=13.2 \mu \mathrm{M}\right.$, $\mathrm{IC}_{50}{ }^{\mathrm{SiHa}}=13.6 \mu \mathrm{M}$ and $\left.\mathrm{IC}_{50}{ }^{\mathrm{C}-33} \mathrm{~A}=10.8 \mu \mathrm{M}\right)$. Triazole derivative of D-SE, D-SET has a significant growth inhibitory effect on HeLa $\left(\mathrm{IC}_{50}=1.1 \mu \mathrm{M}\right)$ and C-33 A $\left(\mathrm{IC}_{50}=1.7 \mu \mathrm{M}\right)$ cell lines, while it has no effect in the HPV-16 + SiHa cells. Contrary to the previous compounds D-HE has a selective antiproliferative effect on HPV $18+$ HeLa cell line with $5.5 \mu \mathrm{M} \mathrm{IC}_{50}$ value (Table 1).

The investigation of tumor selectivity in intact human fibroblast cell lines revealed that the selectivity of the compounds for the cancerous cells are better in the cases of D-HE, D-SE and D-SET or equal in the case of DIM as compared with cisplatin ${ }^{49}$, a drug routinely used in cervical tumor therapy (Table 1).

In view of the chemical similarities and antiproliferative activity of the two secoestrone derivatives we have chosen the more potent triazole compound for the further experiments in order to explore the mechanism of the action. 


\begin{tabular}{|r|c|c|c|c|c|c|}
\hline \multicolumn{1}{|c|}{ Cell type } & \multicolumn{1}{|c|}{$\begin{array}{l}\text { IPV } \\
\text { status }\end{array}$} & \multicolumn{5}{|c|}{$(\mu \mathrm{M})$} \\
\hline & & D-HE & D-SE & D-SET & DIM & cisplatin \\
\hline HeLa & $18+$ & 5.5 & 13.2 & 1.1 & 1.7 & 6.5 \\
\hline SiHa & $16+$ & $>30$ & 13.6 & $>30$ & 0.96 & 12.9 \\
\hline C33-A & - & $>30$ & 10.8 & 1.7 & 2.9 & 3.2 \\
\hline MRC-5 & & $>30$ & n.t. & $>30$ & 1.2 & 3.7 \\
\hline skin fibroblast & & n.t. & $>30$ & n.t. & 3.0 & 21.6 \\
\hline
\end{tabular}

Table 1. Calculated $I C_{50}$ values of the test compounds and cisplatin, measured by MTT assay after incubation for $72 \mathrm{~h}$ on cervical cancer and intact human fibroblast cell lines. n.t. indicates not tested.

\subsection{HOPI double staining}

The morphological changes of the three cervical cancer cell lines generated by the investigated compounds are shown in Figure 3. The presence of living, early apoptotic, late-apoptotic or necrotic cells were distinguished according to the cell morphology and membrane integrity after incubation for $24 \mathrm{~h}$. To detect the form of cell death, two separate pictures from the same field were taken. In HeLa cells D-HE, D-SET and DIM either could provoke the signs of early apoptosis with a bright chromatin condensation, and only higher concentration of D-SET presented the loss of membrane integrity. In the case of C-33 A cells beside a huge chromatin condensation, increased rates of lateapoptotic or necrotic cells could be observed after treatment with D-SET and DIM. Only DIM showed antiproliferative effect on HPV 16+ SiHa cells, but it does not reflected in HOPI double staining after treatment for $24 \mathrm{~h}$, (Figure 4).

\subsection{Cell cycle analysis by flow cytometry}

On the basis of antiproliferative property and morphological changes of the tested compounds cell cycle phase distribution of the treated cells was determined. D-HE elicited slight changes in the cell cycle after $24 \mathrm{~h}$ even in the higher concentrations. After incubation for $48 \mathrm{~h}$ the number of cells in the subG1 and $\mathrm{G} 2 / \mathrm{M}$ phase increased significantly on the expense of G1 population. At $72 \mathrm{~h}$ a significant concentrationdependent increase of subG1 phase with concomitant decrease of G1 and G2/M phases was observed (Figure 5/A). These results indicate that D-HE may cause a blockade in $\mathrm{G} 2 / \mathrm{M}$ phase of the cell cycle ${ }^{50}$. 


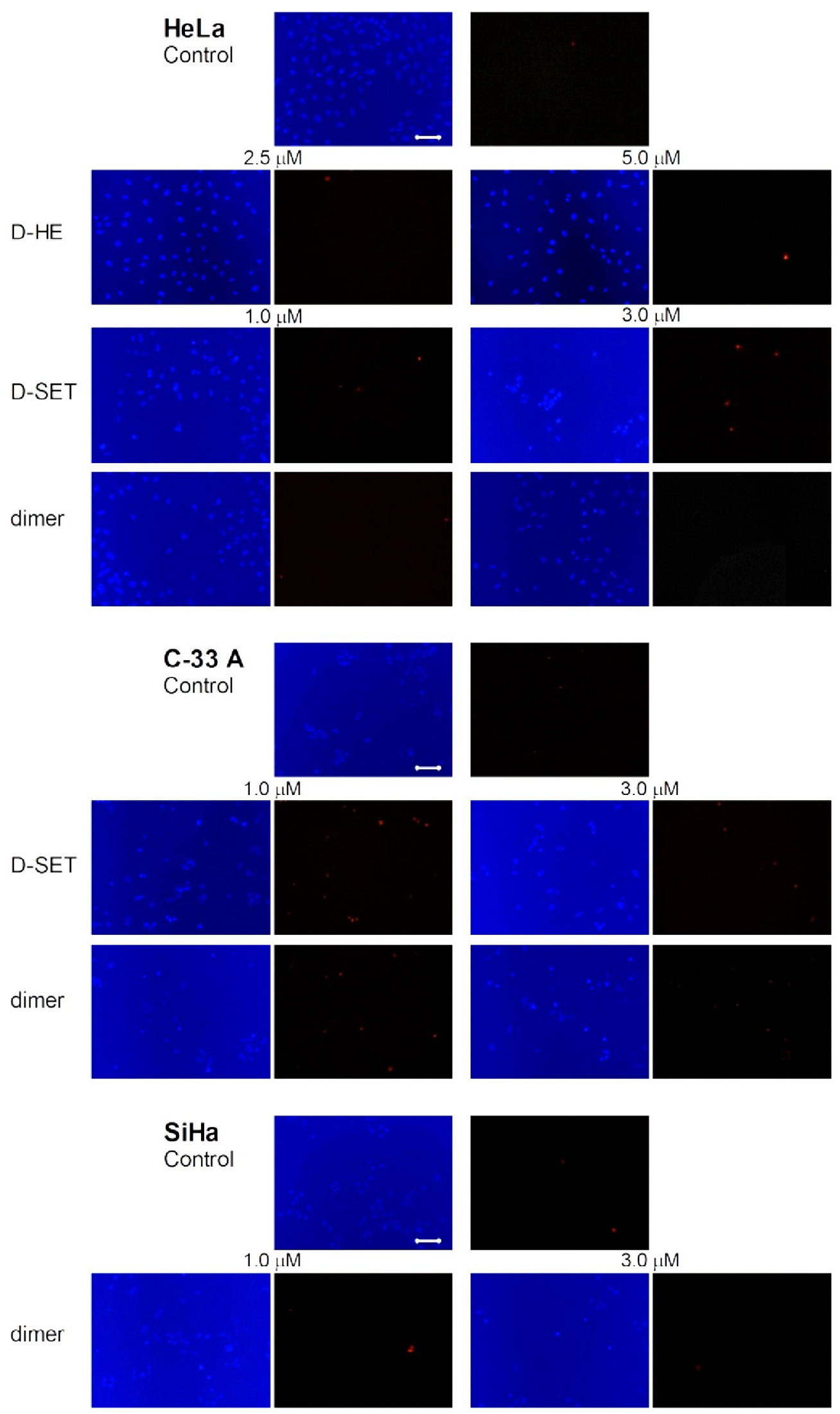

Figure 3. Representative fluorescence microscopy images of HOPI double staining. The early apoptotic and secondary necrotic cells can distinguish by their nuclear morphology (HO: blue) and the integrity of their membranes (PI: red). The bar on control Hoechst 33258 pictures indicate $100 \mu \mathrm{m}$. 

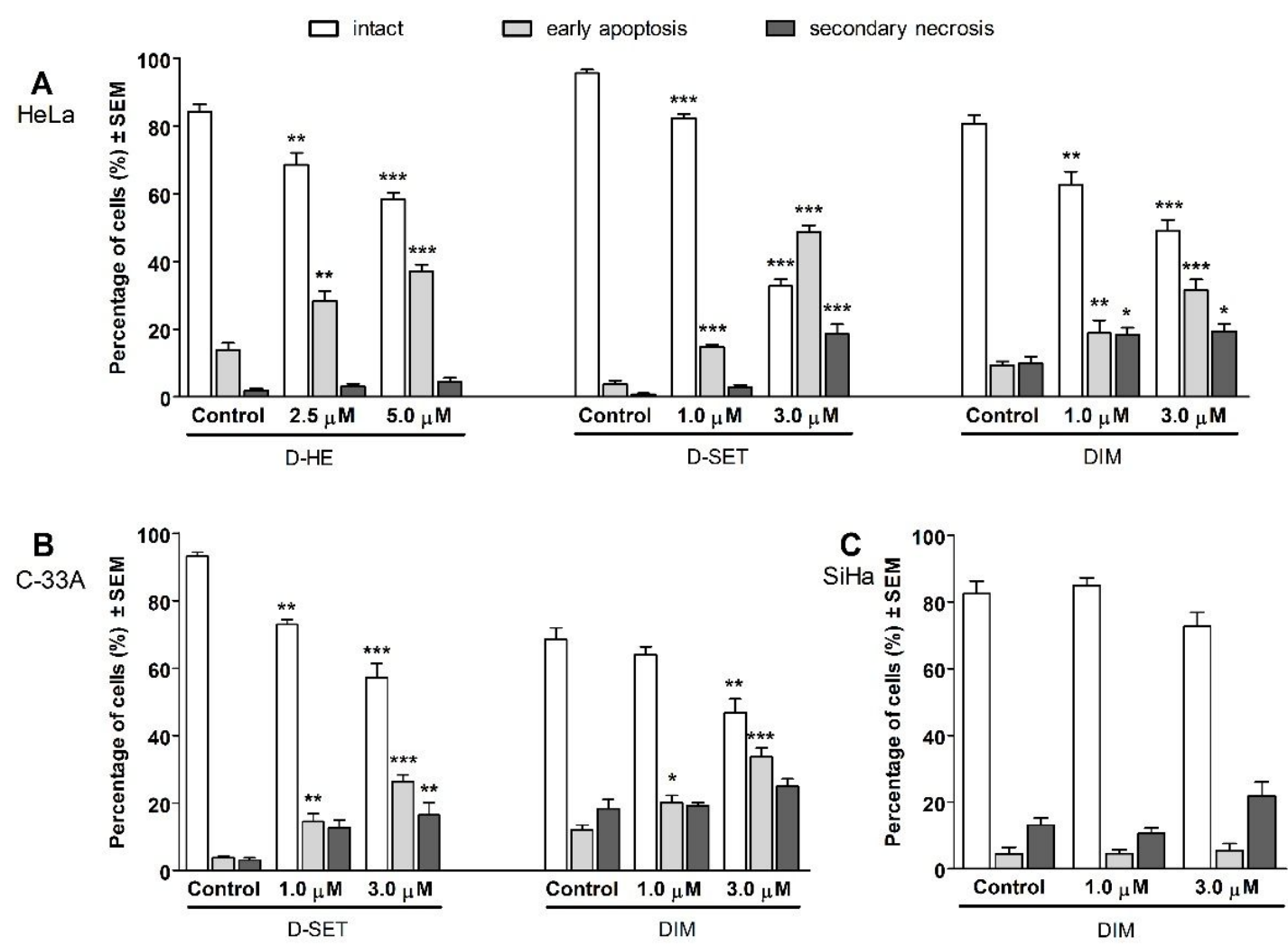

Figure 4. Tested compounds induced apoptotic and necrotic cell death A: with D-HE, D-SET and DIM on HeLa; B: with D-SET and DIM on C-33 A; and C: with DIM on SiHa cells, after $24 \mathrm{~h}$ incubation. Results are means of percentage rates \pm SEM. * indicates $p<0.05, * *$ indicates $p<0.01$ and $* * *$ indicates $p<0.001$ as compared with the control cells, non-significant changes are not indicated.

D-SET induced more robust changes of the cell cycle distribution after $24 \mathrm{~h}$. The results in the two cell lines with different HPV status presented a similar trend. The percentage of hypodiploid cells (subG1 phase) was increased significantly after treatment with $1.0 \mu \mathrm{M}$ or $3.0 \mu \mathrm{M}$ of D-SET. Besides the increased apoptotic subG1 phase, a significant and concentration-dependent increase in the ratio of cells in the G2/M phase followed by a G1 phase reduction was established in both cell lines (Figure 5/B), indicating a cell cycle blockade in the G2/M phase similar to D-HE.

After incubation for $24 \mathrm{~h}$ DIM did not show any significant influence on the cell cycle in the cases of HeLa and C-33 A cells but it has induced a slight increase at G1 and decrease at $\mathrm{S}$ phase in the case of the HPV 16+ SiHa cells (Figure 5/C). Increasing the incubation time we have found significant changes of the cell cycle distribution. For each of three cell lines showed a similar trend after $48 \mathrm{~h}$ incubation. Regardless of the HPV status of the cell lines elevation of the apoptotic subG1 phase was observed; moreover, significant increase was detected in the number of cells in G2/M phase followed by a G1 phase reduction (Figure 5/D). Similar to the other two compounds DIM also can cause a cell cycle blockade at $\mathrm{G} 2 / \mathrm{M}$ phase. 


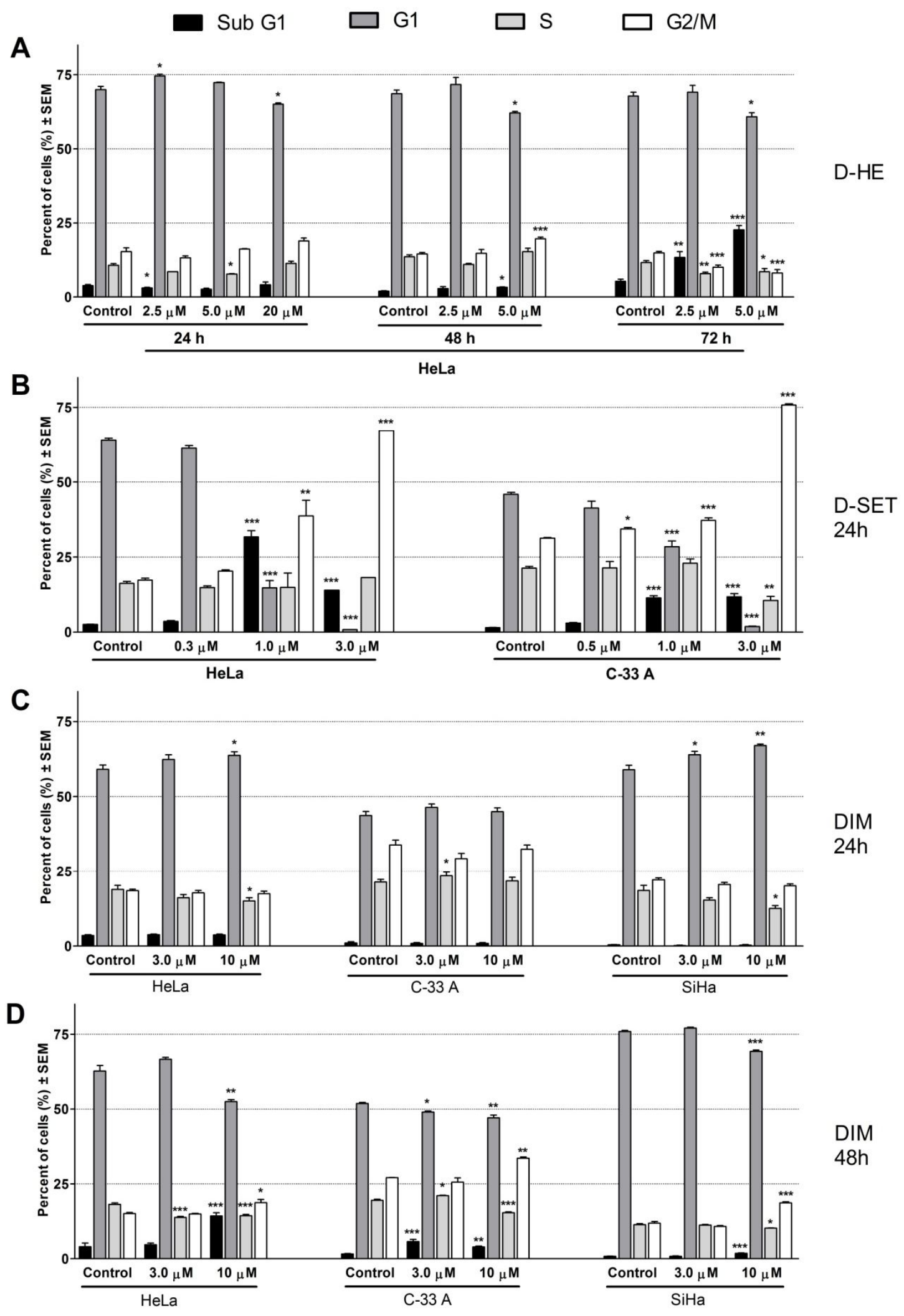

Figure 5. Effects of tested compounds on cell cycle distribution after treatment with D-HE, for 24, 48 and $72 \mathrm{~h}$ on HeLa cells (A); D-SET for $24 \mathrm{~h}$ on HeLa and C-33 A cells (B); DIM for $24 \mathrm{~h}$ on HeLa, C-33 A and SiHa cells (C); and DIM for $48 \mathrm{~h}$ on HeLa, $C-33 \mathrm{~A}$ and SiHa cells (D). Results are means \pm SEM, in each analysis, 20,000 events were recorded. $*$ indicates $p<0.05, * *$ indicates $p<0.01$ and $* * *$ indicates $p<0.001$ as compared with the control cells, non-significant changes are not indicated. 


\subsection{Determination of in situ caspase activity}

After considering the apoptotic markers from morphological and cell cycle changes, caspase-3 activity was determined to confirm the proapoptotic property of the tested compounds. Based on the subG1 phase elevation, HeLa cells were treated with D-HE for $48 \mathrm{~h}$ and with D-SET for $24 \mathrm{~h}$. The results revealed that the enzyme activity was significantly increased after the appropriate incubation time with both of D-HE and D-SET at each applied concentration (Figure 6).

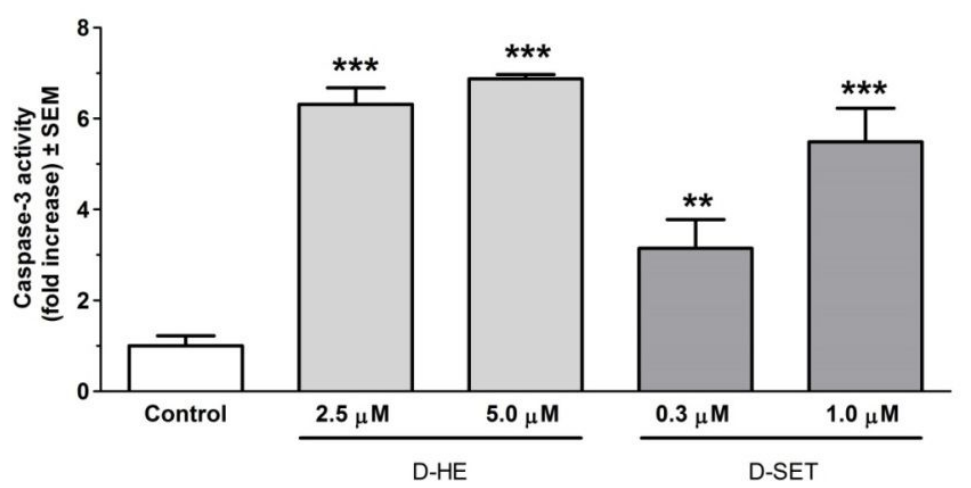

Figure 6. Induction of in situ caspase-3 activity after $48 \mathrm{~h}$ treatment with D-HE and 24 hours treatment with D-SET in HeLa cells. Results show fold increase of enzyme activity of the treated samples compared to the untreated controls. Data are means \pm SEM, $n=3$. * indicates $p<0.05$ and $* * *$ indicates $p<0.001$ as compared with the control cells.

\subsection{Distinction of $G 2$ and $M$ phases by specific flow cytometry}

In view of the similarities of the different compounds actions on all of three cell lines, utilization of HeLa cells seemed rational for the planned further experiments, based on their higher sensitivity. Immunocytochemical flow cytometric analysis was performed in order to distinguish the G2/M population after treatment of D-HE and D-SET, used a concentrations based on the previous flow cytometric results. It was found that after $24 \mathrm{~h}$ incubation D-HE significantly decreased the ratio of phosphorylated histone $\mathrm{H} 3$ protein at position Ser 10 relative to the untreated control cells. On the other hand D-SET significantly increased the ratio of phosphorylated histone $\mathrm{H} 3$ protein similarly to positive control, paclitaxel, a well-known mitotic blocking agent (Figure 7). These results support the theory that D-HE may cause a reduction of cells in $\mathrm{M}$ phase and evoke cell accumulation in the G2 phase while the other test compound, D-SET may induce the cell accumulation and a cell cycle blockade in the $\mathrm{M}$ phase. 
A

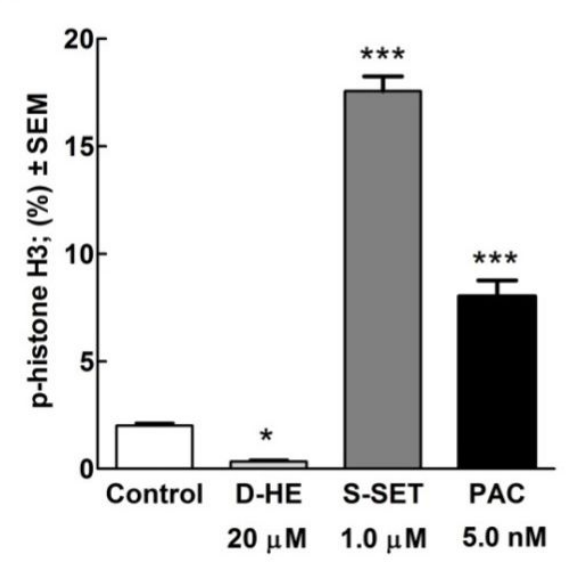

B
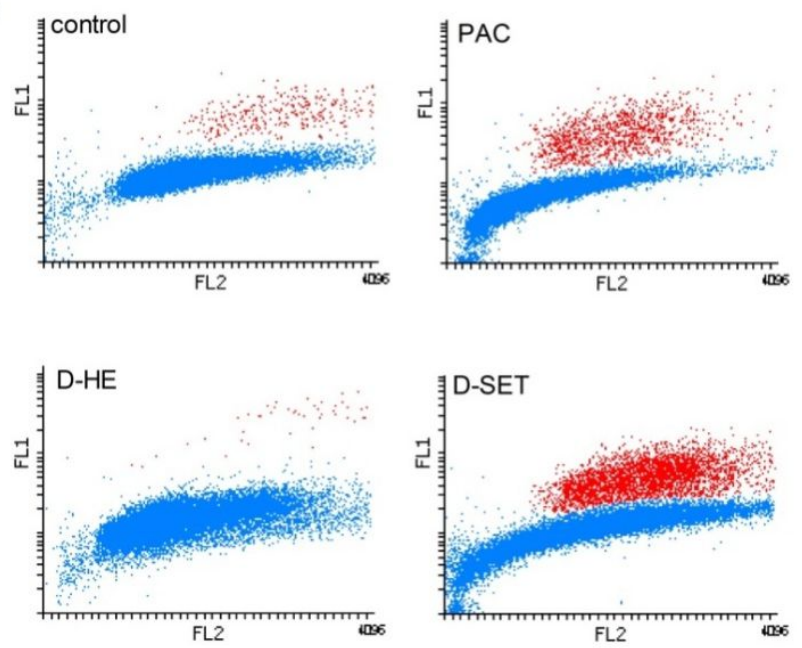

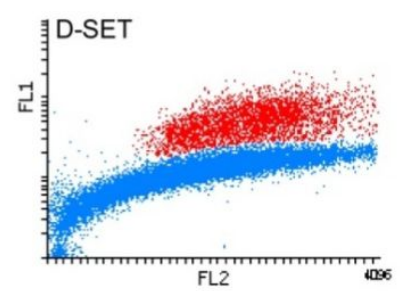

Figure 7. Discrimination of $M$ phase cell population by measuring the phosphorylation of Histone H3 on Ser10, after incubation for 24 hours and treatment with $20 \mu M D-H E$,

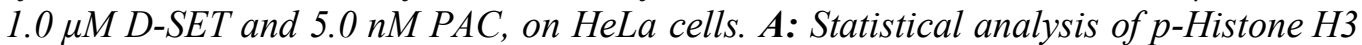
positive cells B: Representative region analysis of flowing dot plot graph (cells in $M$ phase are red labelled). Results are means \pm SEM, in each analysis, 20,000 events were recorded. *indicates $p<0.05$ and $* * *$ indicates $p<0.001$ as compared with the control cells.

\subsection{Analysis of G2/M arrest}

\subsubsection{Reverse transcription PCR studies}

To reveal how D-HE can trigger G2 accumulation, the mRNA expression of the regulatory proteins of $\mathrm{G} 2 / \mathrm{M}$ checkpoint were investigated. Although CDK1 is an executioner enzyme during the $\mathrm{G} 2 / \mathrm{M}$ transition, cyclin $\mathrm{B}$ is responsible for its activation. However the mRNA expression of CDK1 did not show significant alteration while the mRNA expression both of the activating isoforms of cyclin B (B1 and B2) decreased significantly after incubation for $48 \mathrm{~h}$. Cdc25B and Cdc25C are regulatory factors of CDK1-cyclin B complex, and their mRNA expression were significantly reduced after incubation with D-HE for $48 \mathrm{~h}$ as compared with the untreated control cells (Figure 8).

\subsubsection{Western blotting studies}

To investigate the function of CDK1-cyclin B complex protein expressions of phosphorylated and total stathmin were determined by western blot after treatment with D-HE for $48 \mathrm{~h}$. Although the total protein expression of stathmin did not show remarkable alteration (Figure 9/A), the protein expression of phosphorylated form, a 
microtubule destabilizing protein phosphorylated and therefore inactivated by CDK1cyclin B complex, significantly decreased compared to untreated control cells (Figure 9/B).

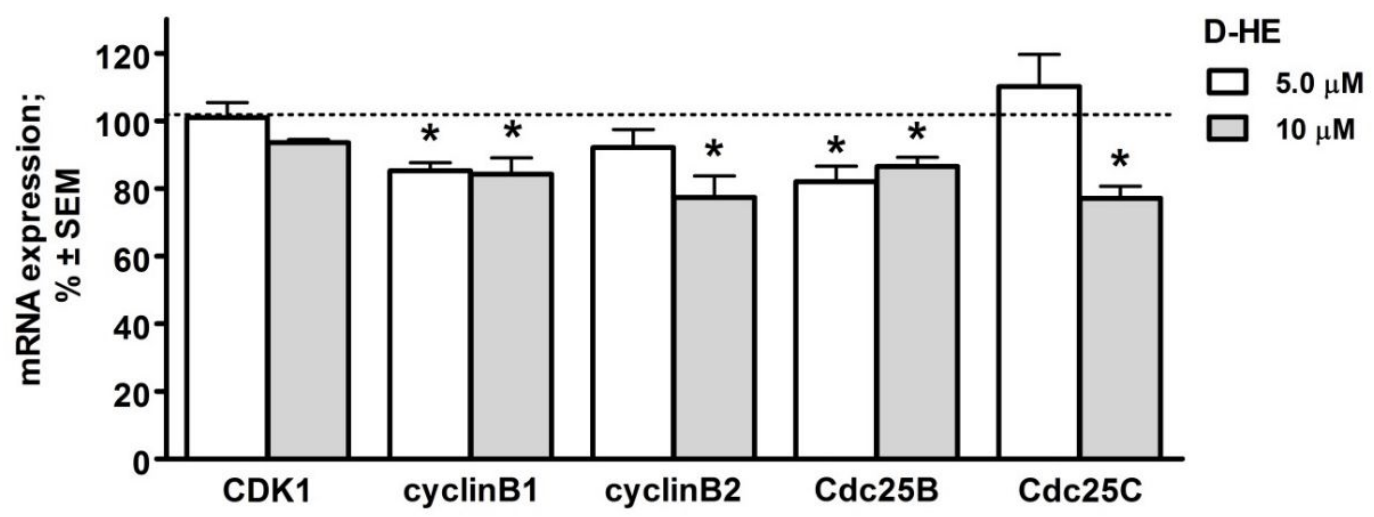

Figure 8. The $m R N A$ expression of $G 2 / M$ checkpoint regulating factors after incubation with 5.0 and $10 \mu M D-H E$ for $48 \mathrm{~h}$ on HeLa cells, determined by reverse-transcription $P C R$. Results show rate of $m R N A$ expression of the treated samples compared to the untreated controls (dashed line at 100\%). Data are means \pm SEM, of the data from two separate measurements and $n=6$. * indicates $p<0.05$, as compared with the control cells, non-significant changes are not indicated.
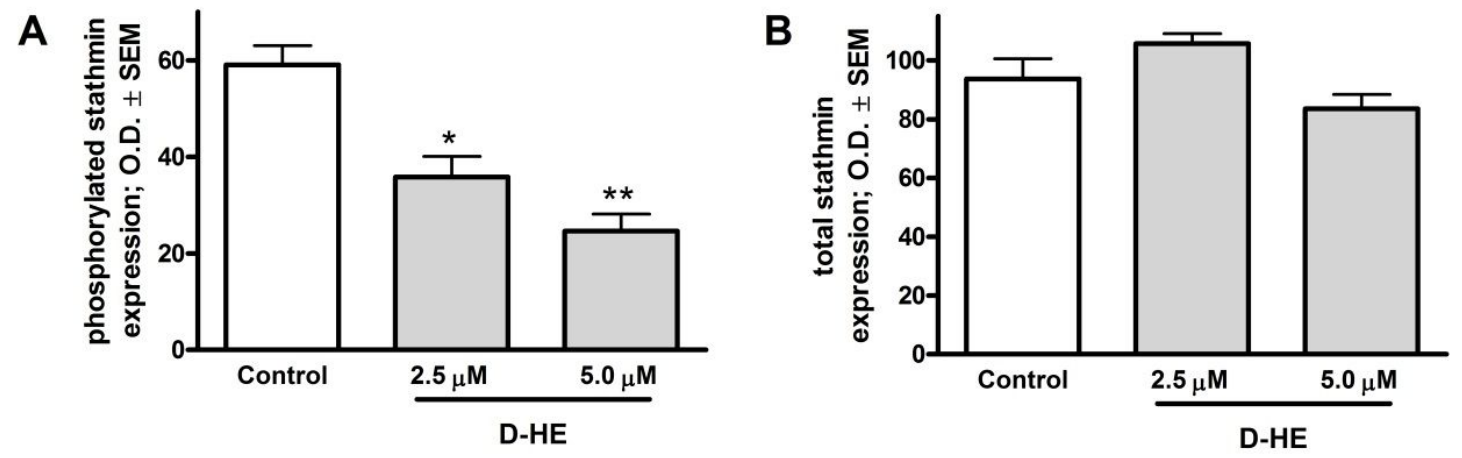

phospho-
stathmin

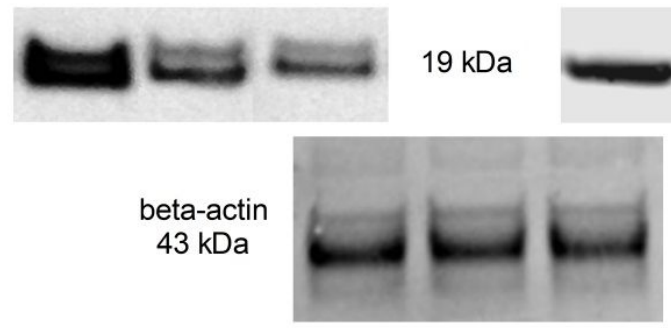

Figure 9. Statistical analysis of protein expression of phosphorylated (A) and total stathmin (B) after treatment with 2.5 and $5.0 \mu M$ D-HE, for 48h, on HeLa cells, and representative membrane pictures $(\boldsymbol{C})$. Results are means $\pm S E M$, of the data from two separate measurements and $n=6 . *$ indicates $p<0.05$ and $* *$ indicates $p<0.01$ as compared with the control cells, non-significant changes are not indicated. 


\subsection{Tubulin polymerization assay}

The investigation of histone H3 revealed that D-SET caused cell cycle blockade in the $M$ phase of the cell cycle. During the $M$ phase the equilibrium between the polymerization and degradation of microtubuli from tubulin dimers has a crucial role in cell division ${ }^{51}$, therefore tubulin can be a probable target of D-SET. Based on this consideration the direct action of D-SET on tubulin polymeriaztion has been determined by means of photometry. The kinetic curves show that $100 \mu \mathrm{M}$ D-SET accelerated the tubulin polymerization in the growth phase (Figure 10/C), which was also reflected in the calculated $\mathrm{V}_{\max }$ values. Because of the similar structure, the actions of D-SE and DIM on tubulin polymerization were also determined; $200 \mu \mathrm{M}$ D-SE and $100 \mu \mathrm{M}$ of DIM also can increase the maximum rate of tubulin polymerization relative to the untreated control sample (Figure 10/B and 10/D). To confirm our previous results that D-HE act in G2, not in M phase, D-HE's direct action on tubulin polymerization was recorded as well. As it was expected D-HE did not significantly alter the tubulin polymerization, even at high $(500 \mu \mathrm{M})$ concentrations (Figure 10/A).

For the statistical analysis maximum rate of microtube formation was calculated. While D-HE did not show considerable effect on tubulin polymerization; both of the D-secoestrone derivatives (D-SE, D-SET) and their dimer analogue (DIM) significantly increased the calculated $\mathrm{v}_{\max }$ value, similar to paclitaxel, a well-known microtubule stabilizer (Figure 10/E).

\subsection{Analysis of cell migration using Wound healing assay}

Besides the direct antiproliferative activity, another important part of the mechanism of action can be the antimetastatic property of the anticancer drug candidate. The migrating behavior of the cancer cells was observed after treatment with D-HE and D-SET by wound healing assay. The untreated control HeLa cells closed around $60 \%$ of the wound area generated by the insert after $24 \mathrm{~h}$. D-HE did not show significant difference as compared with the untreated control cells while D-SET-treated cells failed to close the wound and concentration-dependently inhibited the migration of HeLa cells (Figure 11). 

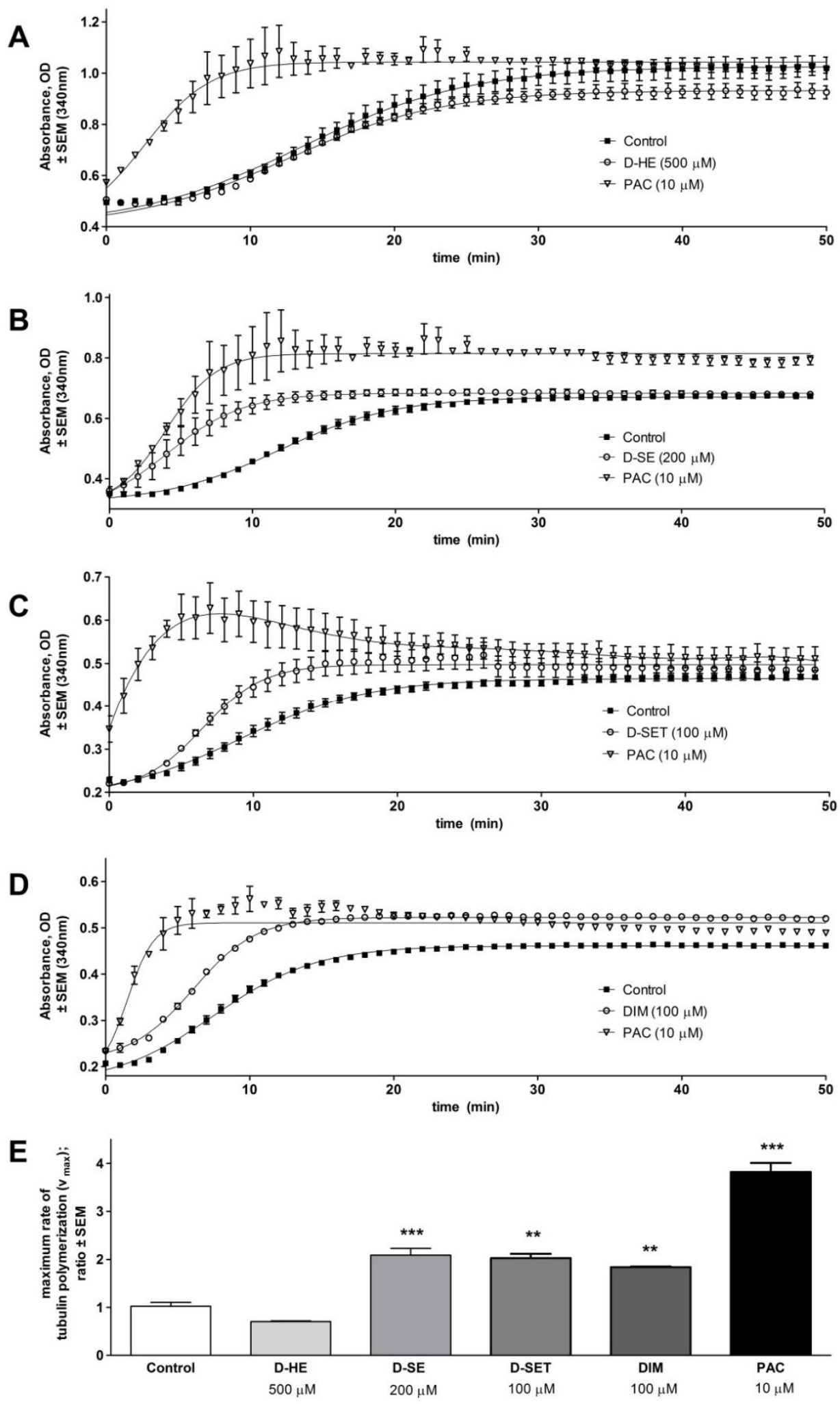

Figure 10. The direct effect of the test compounds on tubulin polymerization in a cell independent experimental system, in vitro. Kinetic curves of 50-min kinetic reaction, after incubation with $500 \mu M$ D-HE (A), $200 \mu M D$ D-SE (B) $100 \mu M$ D-SET (C) and $100 \mu M$ DIM (D) General buffer and $10 \mu M$ PAC was used as negative and positive control, respectively. $\boldsymbol{E}$ : Maximum rate of tubulin polymerization. Results are means $\pm S E M$ of the data on two separate measurements with duplicates. ** indicates $p<0.01$ and $* * *$ indicates $p<0.001$ as compared with the negative control samples, non-significant changes are not indicated. 

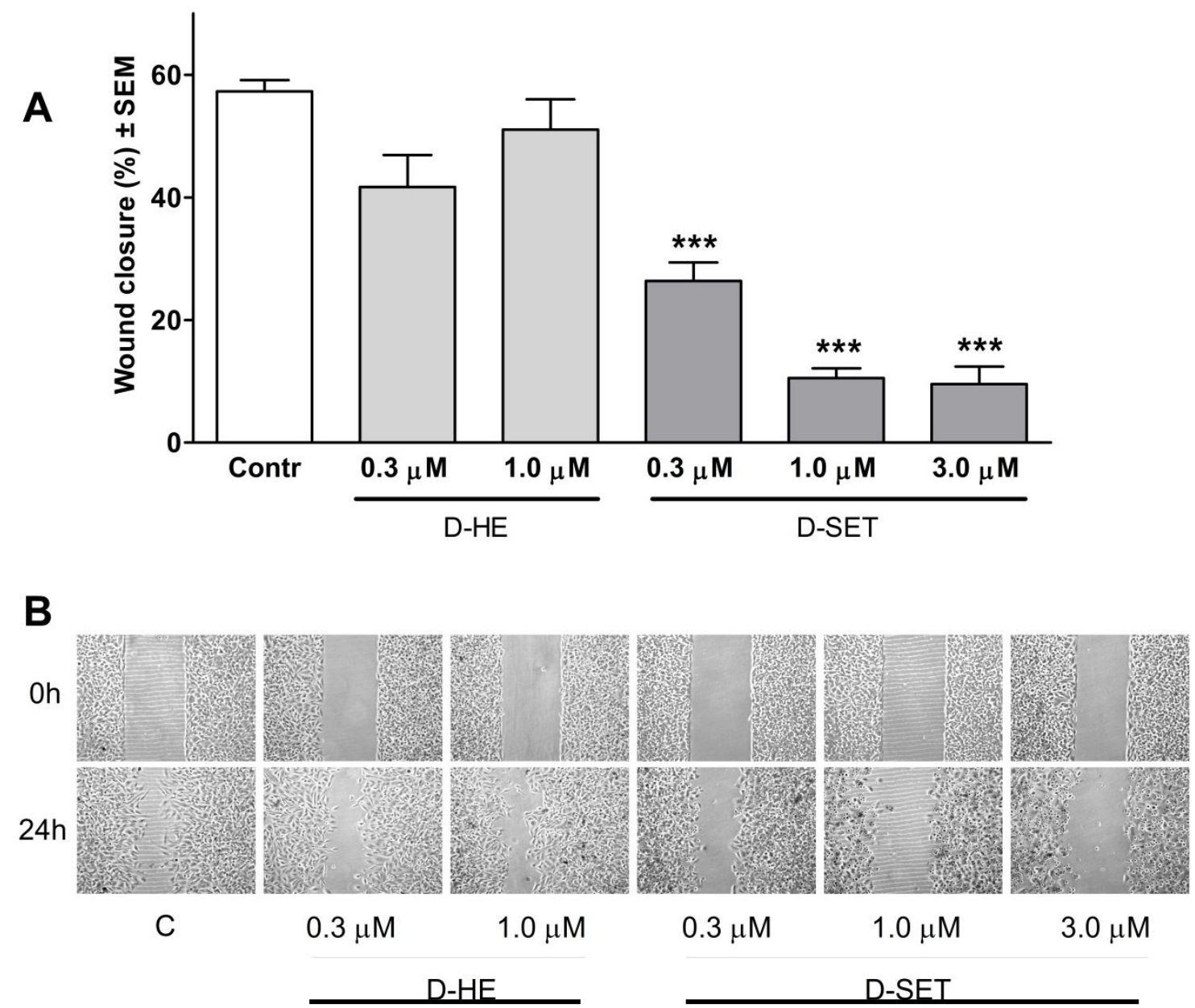

Figure 11. Migratory capacity of HeLa cells after 24 hours D-HE and D-SET treatment, analysed by wound healing assay. (A) Rate of migration was calculated as the ratio of wound closure in treated samples after $24 \mathrm{~h}$ and $0 \mathrm{~h}$ compared to the ratio of wound closure in untreated control samples after $24 \mathrm{~h}$ and $0 \mathrm{~h}$. (B) Representative images of the migrating cells. Results are mean values $\pm S E M$ of the data on three separate measurements with triplicates. $* * *$ indicates $p<0.001$, non-significant changes are not indicated.

\subsection{Analysis of cell invasion using Boyden chamber assay}

After the finding that D-SET significantly can inhibit the migration of cancerous cells, the anti-invasive effect of the compound was additionally examined with the Matrigel-coated Boyden chamber. The layer occludes the pores of the membrane, blocking the non-invasive cells from migrating through the membrane. On the other hand, it allows the invasive cells to detach and invade through the membrane. It was found that D-SET significantly inhibited the invasion of HeLa cells as compared with the untreated controls (Figure 12). This inhibition was present after the exposure of $0.1 \mu \mathrm{M}$, which is considerably lower than the effective antiproliferative concentration. Additionally, the inhibition became more pronounced as the concentration was raised. 
A

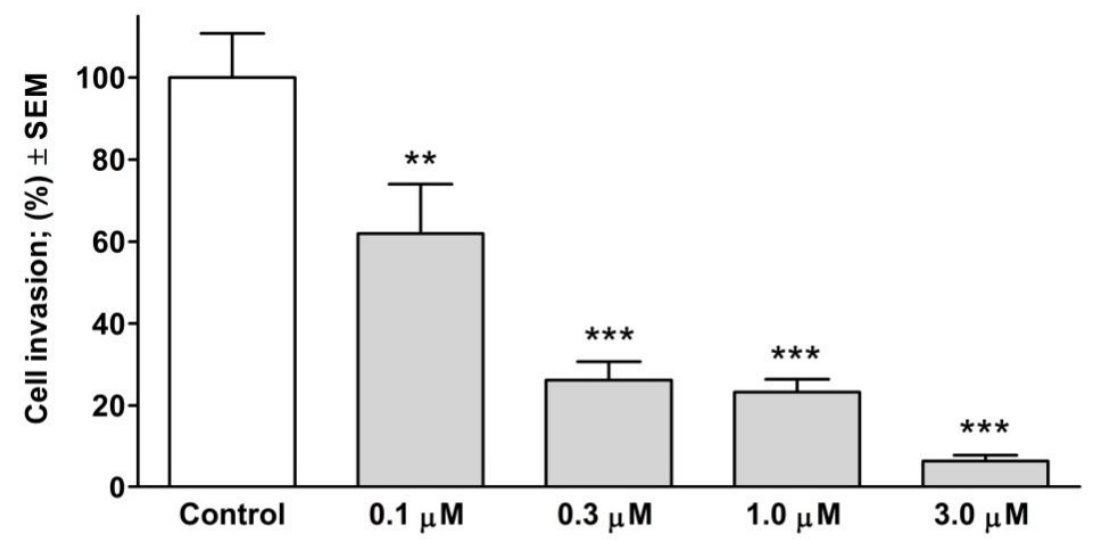

B

C

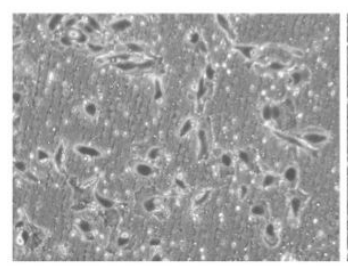

$0.3 \mu \mathrm{M}$

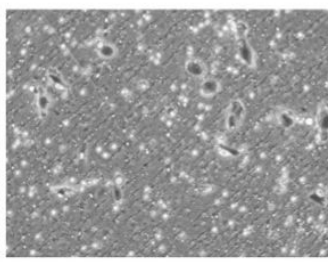

$1.0 \mu \mathrm{M}$

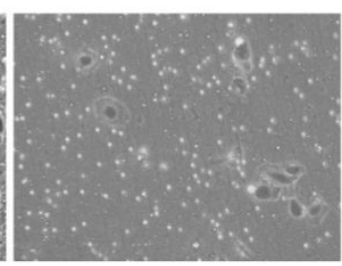

$3.0 \mu \mathrm{M}$

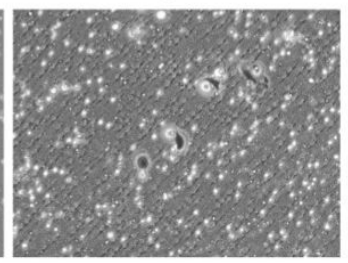

Figure 12. Cell invasion capacity of HeLa cells through matrigel coated Boyden chambers. (A) Statistical analysis of the percentage of invasive cells after $24 \mathrm{~h} D$-SET treatment. (B) Images from a visual field of one representative experiment. Results are mean values \pm SEM of the data on three separate measurements with duplicates. $* *$ indicates $p<0.01$ and $* * *$ indicates $p<0.001$. 


\section{DISCUSSION}

The first use of compounds with steroid structure in anticancer therapy was from different herbs. A large body of evidence indicates that steroid-like triterpenes, e.g. betulinic or oleanolic acid and their derivatives exert potent proapoptotic and antimigratory effects on numerous human cancer cell lines ${ }^{52-58}$. Antiproliferative effects of several other natural steroids have been described: steroid alkaloids from the Solanaceae family; solasonine, solamargine, solanine, or some marine sponge extracts; plakinamines $\mathrm{N}$ and $\mathrm{O}$ exert anticancer effects due to their apoptosis-inducing activities $^{58-62}$. The steroid cardiac glycosides digoxin and digitoxin also display pronounced tumor-inhibitory effects through several different cell types ${ }^{63,64}$ and some of their derivatives have passed through successful phase I clinical trials as potential anticancer drugs ${ }^{65}$. Besides these natural plant steroids there are some endogenous steroid metabolites inside the human body such as 2-ME or conjugated estrogen metabolites which have been described as potent antiproliferative agents ${ }^{21-24,66-69}$.

Active natural compounds and metabolites can be the basis for synthetic chemistry to design novel, more effective drug candidates. Based on the promising results with A-ring-modified 2-ME many new analogues were examined. It is known that small differences in molecular structure can cause significant differences in biological activities. Therefore besides the antiproliferative effect the conventional receptor-binding and modulating capacity is another important question concerning the therapeutic use of compounds with steroid structure. Well-established structure-activity studies revealed association between the modifications of the D-ring and the estrogen receptor-binding capacity. It has been described that D-homoestrone, does not exert estrogenic effect in an in vivo uterotrophic assay system ${ }^{34}$. Less information is available from the secoestrone derivatives. Anstead et al. reviewed the criteria of receptor binding and concluded that C14 - C17 are cavity vertices with a favorable interaction, and that the C15-C16-C17 crescent should be at the appropriate position in the receptor lysine and two cysteine residues, and therefore the integrity of the D-ring is necessary for high receptor affinity ${ }^{70}$. Additionally, Jovanovic-Santa et al. confirmed that numerous newly synthetized D-secoestrogen derivatives undergo a total loss of estrogen activity due to the fragmentation of their D-ring ${ }^{31-33,71}$. 
Our previous results demonstrated that D-ring modification in the estrogen structure can cause a potent antiproliferative effect in vitro ${ }^{29,34-36,46,50,72}$. In these studies, we reported considerable effects of several D-homoestrones, D-secoestrones, D-secoestrone-triazoles and dimers from 13-epiestrones and D-secoestrone-triazoles in numerous different cell lines. The 4 most active compounds were selected, and it was found that the major differences of the efficiency were at the different pathological cervical cancer cell lines. Although, DIM displays a potential effect on all cervical cell lines independently from their HPV status (HPV 18+, 16+ and negative), D-SET (one part of the dimer) does not able to inhibit the growth of HPV 16+ SiHa cells, just the other two types (HPV 16+ HeLa and HPV negative C-33 A cells). Additionally, leaving the triazole group from the secoestrone-structure in the case of D-SE resulted in the same antiproliferative spectrum as DIM, but with higher $\mathrm{IC}_{50}$ values. Finally D-HE, the compound with expanded but closed D-ring has a substantial selective antiproliferative activity on the HPV 16+ HeLa cells. A possible explanation of the different sensitivity may lie at the different levels of apoptotic proteins depending on the HPV status. Hougardy et al. reported that the expression of the mitochondria-related proapoptotic proteins Bid and Bcl-2 are much less expressed in SiHa than in HeLa and C-33 A. Bid is an essential intermediate between the extrinsic and intrinsic apoptotic pathway while Bax or Bak cannot be activated in the lack of Bid and cannot exert their proapoptotic effect via the mitochondrial pathway ${ }^{73}$. Additionally, Aguilar-Lemarroy et al. reported that HPV16-carrying cells were remarkably resistant to CD95-mediated apoptosis with deficient Bcl-2. They also found that SiHa cells failed to recruit FADD and pro-caspase-8 through the death effector domain because FADD is missing from the complex. The inability to build up a functional death-inducing signaling complex (DISC) could have the result that SiHa cells may avoid apoptotic signals in the cases of D-HE and D-SET ${ }^{74}$.

The tumor selectivity is an important part of the mechanism of action of a new anticancer drug We have found that the tumor selectivity of the test compounds were better as compared with cisplatin ${ }^{49}$, except the dimer derivative (DIM), which selectivity was equal to cisplatin, a routinely used agent during the cervical cancer therapy.

To investigate the mechanism of antiproliferative action, the apoptosis-inducing effects of the compounds were first proven by three independent methods; HOPI double staining, measurement of caspase-3 activity and cell cycle analyses. After incubation for $24 \mathrm{~h}$, morphological changes confirm the concentration-dependent proapoptotic effect of the compounds on the concerned cell lines. Briefly, D-HE induced apoptotic morphology 
on HeLa, D-SET on HeLa and C-33 A and DIM on all of the three cervical cell lines. In the case of C-33 A cells, elevation of the concentration of D-SET and DIM lead to the formation of late apoptotic or secondary necrotic cells with loss of membrane function. The progressive elimination of DNA also proved to be related with an apoptotic process occurring as an increased subG1 population ${ }^{39}$, therefore we performed flow cytometric analysis. The results of the cell cycle analysis revealed that all of the tested compounds, on all of the affected cell lines, may increase the cell number of subG1 population, followed by cell accumulation in $\mathrm{G} 2 / \mathrm{M}$ phase, in a concentration and incubation time dependant way. D-SET has the most substantial effect on cell cycle, marked elevation of the subG1 and G2/M phase were observed after $24 \mathrm{~h}$ (both on HeLa and C33-A). In contrast DIM needs $48 \mathrm{~h}$ incubation time to elicit similar trend on all of the three cervical cell lines. D-HE may also cause increased subG1 and G2/M phase after $48 \mathrm{~h}$ but the sharp rise of subG1 population was observed only after $72 \mathrm{~h}$. Additionally, caspase-3 is a crucial executioner of apoptosis, and therefore after the morphological evidences, for the biochemical demonstration of apoptosis caspase-3 activation was detected. Both D-HE and D-SET increased the activity of caspase-3 enzyme significantly after the appropriate incubation time on HeLa cells. According to these data we can infer that all of the investigated compounds have potent proapoptotic activity resulting in apoptotic attributes: specific morphological changes, DNA fragmentation and caspase enzyme activation.

Besides the detection of apoptosis, cell cycle analyses also provided important details about the mechanism of action of the tested steroid derivatives. All the compounds caused significant elevation of cell number in the G2/M phase indicating a cell cycle blockade at that phase. These results are consistent with previously reported data with the alkaloid solanidine or the natural human metabolite $2-\mathrm{ME}^{23,61}$. Furthermore, it has been reported that 2-ME is related with $\mathrm{M}$ phase arrest due to activation of the mitotic spindle assembly checkpoint ${ }^{66,75}$. To investigate whether our steroid analogues elicit cell cycle blockade in the G2 or the M phase, phosphorylated histone-H3 (Ser10) was measured after the treatment with the steroid analogues. Histone H3 phosphorylation at Ser(10) correlates with the G2 to M transition, this phosphorylation has been indicated to be constitutively activated in the metaphase while at the end of mitosis $\mathrm{H} 3$ dephosphorylation occurs rapidly ${ }^{40}$. It was found that while all the tested steroid analogues can cause $\mathrm{G} 2 / \mathrm{M}$ phase arrest, their detailed mechanisms are different. According to our experimental result cell cycle affecting action of the secoestrone 
analogue with opened D-ring (D-SET) is consistent with that of the previously mentioned 2-ME; both of them caused cell cycle arrest at the M-phase. In contrast the ring expanded D-HE with closed D-ring triggered G2 phase blockade with dramatically decreased proportion of phosphorylated histone $\mathrm{H} 3$.

The result indicating that HeLa cells after D-HE treatment are not able to arrive at the metaphase and initiate the first step of the mitosis was unexpected, therefore the alteration of the mRNA expression of the $\mathrm{G} 2 / \mathrm{M}$ checkpoint regulating proteins were determined. The main regulator of the $\mathrm{G} 2$ to $\mathrm{M}$ transition is the $\mathrm{CDK} 1 /$ cyclin $\mathrm{B}$ complex, composed of the executor protein cyclin dependent kinase 1 and cyclin B subunits. The CDK1 expression is relatively constant during the cell cycle; therefore entry into mitosis depends on the synthesis of cyclin B. The activation of the CDK1/cyclin B complex also regulated through activating phosphorylations by the CDC25 family. Our results confirm that the background of the D-HE caused G2/M failure lies on the inhibition of the regulatory proteins at $\mathrm{G} 2 / \mathrm{M}$ phase checkpoint. Although the mRNA expression of CDK1 does not show significant alteration after $48 \mathrm{~h}$ D-HE treatment, the expression of cyclin B1 and B2 decreased significantly. Additionally, the mRNA levels of CDC25B and $\mathrm{C}$ (the direct upstream regulators of CDK1/cyclin B complex) are also reduced significantly. The decreased levels of the activating proteins of CDK1 indicate a reduced functional activity of the CDK1/cyclin B complex. Stathmin is one of the numerous targets of CDK1 and an important regulatory protein of microtubule dynamics in a phosphorylation-dependent manner. The active, dephosphorylated form of stathmin interacts with two tubulin heterodimers and have important role in tubulin-microtubuli equilibrium. The active CDK1 is able to phosphorylate stathmin protein, and therefore inactivate it, and this phosphorylated, inactive form of stathmin allows the microtubule formation from tubulin dimers into a mitotic spindle. CDK1/cyclin B complex failure results in inappropriate stathmin, therefore the cell cannot assemble a functional mitotic spindle and arrest in the G2/M phases of the cell cycle occurs ${ }^{76-78}$. Our results revealed that whereas the protein expression of total stathmin did not changed, the phosphorylated (inactive) form of stathmin decreased significantly after 48 hours treatment with D-HE. These western blot results confirm our theory concerning the reduced functional activity of CDK1, and support that D-HE treatment result in dysregulation and dynamic instability of the tubulin-microtubule system and the consequent G2 phase accumulation of the cells, evoking the apoptotic process. 
Besides the investigation of the tubulin regulation through stathmin protein, the direct effect of the tested steroid compounds on tubulin polymerization is another crucial possibility of their antiproliferative mechanism of action. The A-ring substituted 2-ME has been reported to inhibit tubulin polymerization during the initial steps of mitosis by interacting with its colchicine-binding site ${ }^{79}$. Even D-HE does not exhibit any action on tubulin polymerization in an in vitro cell-independent experimental system, all of the other investigated compounds, D-SE, D-SET and DIM significantly increased the maximum rate of microtubule formation, and enhanced the polymerization. Tubulin polymerization is an important and crucial progress during the mitosis, the imbalance between polymerization and depolymerization of microtubuli leads to fatal consequence with the termination of cell division ${ }^{80}$. This shift in either direction is utilized in tumor therapy, including the depolymerizing agent nocodasole or the tubulin-polymerizing agent paclitaxel. Our results confirmed $\mathrm{M}$ phase blockade caused by the secoestrogen derivatives is closely related with their direct effect on tubulin polymerization. Secoestrogens shift the dynamic equilibrium between tubulin dimers and microtubule towards microtubule assembly and stabilization, resulting in an aberrant mitosis. As a consequence, secoestrogens treated cells cannot continue the cell cycle progression and accumulate at the M-phase; triggering apoptotic cell death.

During the investigation of the mechanism of new drug candidate its antimetastatic effect is another important characteristic in question. The presence of metastasis is highly associated with poor patient prognosis and the dissemination of cancer cells from the primary tumor to a distant organ can lead to severe organ failure, and that is the most frequent cause of patient's death ${ }^{81-83}$. Metastasis formation is a complex, multistage process including changes in cell adhesion, migration and invasion $^{81,84}$. The physiologically most potent estrogen hormone, $17 \beta$-estradiol has been described as an invasion inducing agent via the PI3K signaling pathway in cervical ${ }^{85}$, endometrial $^{86}$ and ovarian ${ }^{87}$ cancer cell lines. Previous studies also revealed that the antiproliferative, A-ring modified estrogen metabolite 2-ME has antimetastatic effect on several cancer cell lines ${ }^{88,89}$. In addition Stander et al reported that a synthetic sulfamoylated estrogen analogue also has antimetastatic effect associated with acidotic microenvironmental conditions in tumors ${ }^{90}$. We found no previous result concerning the effect of D-homo- or D-secoestrogens on cell motility. D-HE and the most potent D-SET were selected for the investigations of cell migration and invasion. According to our findings D-HE did not able to inhibit cell migration in the used subeffective 
concentrations, while D-SET, similar to the widely investigated 2-ME had a potent antimigratory capacity below its antiproliferative concentration, after incubation for $24 \mathrm{~h}$. Besides the cell migration, invasion through the basal membrane is another important step during the metastatic pathway. Our results show, that the previously determined antimigratory D-SET significantly inhibited cancer cell invasion in our experimental system in vitro. The used subantiproliferative concentration is another major highlight of tumorspecificity, since at the used low concentrations compounds have no toxic effect on intact cells (cells without motility changes) and therefore this approach can reduce the incidence of side effects. In conclusion our findings revealed that opening the D-ring may lead to potent anti-metastatic compounds, with a significant inhibitory activity on cell motility, while D-ring expansion seems to be less effective in the design of new drug candidates with anti-metastatic characteristics. 


\section{SUMMARY}

In summary our current results have demonstrated, that

3 D-homoestrogens, 13 D-secoestrogens and 1 dimer derivative from the investigated 46 novel estrogen analogues show potent antiproliferative effect on different gynecological cancer cell lines, in vitro. The tumor selectivity of the four most potent compounds proved to be better than or equal to that of cisplatin, a routinely used drug in cancer therapy.

$>$ The four most potent compounds have different spectrum of activity on the three cervical cancer cell lines, depending on their pathological background. D-HE proved to be selective on the HPV 18+ HeLa cells; D-SET inhibited the growth of both the HPV 18+ HeLa and HPV- negative C-33 A cell lines. DIM shows the broadest spectrum with inhibition of all of the three tested cell lines (HPV 18+ HeLa, HPV- negative C-33 A and HPV 16+ SiHa). These findings suggest that opening the D-ring may lead to a broader anitproliferative spectrum.

D-HE, D-SET and DIM show pronounced proapoptotic effect on their sensitive cell lines as evidenced by fluorescent double staining and flow cytometric analysis. In the cases of D-HE and D-SET caspase-3 activation was also observed.

$>$ Even the regular flow cytometric analysis revealed that all of D-HE, D-SET and DIM cause G2/M arrest in cell cycle progression; the detailed investigations show, that D-HE exerts its effect in G2 phase resulting functional failure of CDK1/cyclin B complex at G2/M checkpoint. In contrast D-SET and DIM provoke $\mathrm{M}$ phase blockade as a consequence of their influence on tubulin polymerization. These results lead to the conclusion, that different modifications of the D-ring determine different mechanisms of action during the cell cycle.

$>$ In subantiproliferative concentration D-HE did not exert any changes in cell motility, while D-SET significantly inhibited the cell migration and invasion at our in vitro experiments.

In conclusion, even in recent years there has been an increasing interest in antiproliferative estrogens, before our study D-ring modified analogues have not been investigated. Our findings suggest that D-homo- and D-secoestrogens have different tumor selectivity with a different antiproliferative mechanism of action. D-HE causes a functional loss of $\mathrm{CDK} /$ cylinB complex and provokes cell cycle arrest before cervical cancer cells start to enter mitosis at G2 phase, followed by the induction of apoptosis. 
This tumor-inhibiting mechanism of action was demonstrated only in HPV 18+ HeLa cells. In contrast, D-secoestrone derivatives treated cells undergo of G2/M checkpoint and the tested molecules with opened D-ring cause $M$ phase blockade by disrupting the tubulin polymeerization, leading to programmed cell death. Besides the pro-apoptotic effect of D-SET, results revealed its anti-migrating and anti-invading potential leads to the conclusion that D-SET shows antimetastatic potential by preventing cancer cell motility.

As regards all of the presented findings, D-ring modified estrogen derivatives can be considered as drug candidates with a promising new mechanism of action among the antiproliferative steroids and potentially allows the design of further anticancer drugs. 


\section{REFERENCES}

1. Torre LA, Bray F, Siegel RL, Ferlay J, Lortet-Tieulent J, Jemal A. Global cancer statistics, 2012. CA: A Cancer Journal For Clinicians. 2015;65:87-108

2. Ferlay J, Steliarova-Foucher E, Lortet-Tieulent J, Rosso S, Coebergh JW, Comber $\mathrm{H}$, et al. Cancer incidence and mortality patterns in Europe: Estimates for 40 countries in 2012. European Journal of Cancer. 2013;49:1374-1403

3. Hussein WM, Anwar WA, Attaleb M, Mazini L, Forsti A, Trimbitas RD, et al. A review of the infection-associated cancers in north african countries. Infectious Agents and Cancer. 2016;11:35

4. Mesri EA, Feitelson MA, Munger K. Human viral oncogenesis: A cancer hallmarks analysis. Cell Host \& Microbe. 2014;15:266-282

5. Levy P, Bartosch B. Metabolic reprogramming: A hallmark of viral oncogenesis. Oncogene. 2016;35:4155-4164

6. Ghittoni R, Accardi R, Chiocca S, Tommasino M. Role of human papillomaviruses in carcinogenesis. Ecancermedicalscience. 2015;9:526

7. Goodman A. Hpv testing as a screen for cervical cancer. BMJ. 2015;350:h2372

8. Chidyaonga-Maseko F, Chirwa ML, Muula AS. Underutilization of cervical cancer prevention services in low and middle income countries: A review of contributing factors. The Pan African Medical Journal. 2015;21:231

9. Valentino K, Poronsky CB. Human papillomavirus infection and vaccination. Journal of pediatric Nursing. 2016;31(2):e155-66

10. Kumar S, Biswas M, Jose T. Hpv vaccine: Current status and future directions. Medical Journal, Armed Forces India. 2015;71:171-177

11. Wheeler CM. Advances in primary and secondary interventions for cervical cancer: Human papillomavirus prophylactic vaccines and testing. Nature Clinical Practice. Oncology. 2007;4:224-235

12. Movva S, Rodriguez L, Arias-Pulido H, Verschraegen C. Novel chemotherapy approaches for cervical cancer. Cancer. 2009;115:3166-3180

13. Suh DH, Kim M, Kim HJ, Lee KH, Kim JW. Major clinical research advances in gynecologic cancer in 2015. Journal of Gynecologic Oncology. 2016;27:e53

14. Tewari KS, Sill MW, Long HJ, 3rd, Penson RT, Huang H, Ramondetta LM, et al. Improved survival with bevacizumab in advanced cervical cancer. The New England Journal of Medicine. 2014;370:734-743

15. Hanahan D, Weinberg RA. The hallmarks of cancer. Cell. 2000;100:57-70

16. Hanahan D, Weinberg RA. Hallmarks of cancer: The next generation. Cell. 2011;144:646-674

17. Floor SL, Dumont JE, Maenhaut C, Raspe E. Hallmarks of cancer: Of all cancer cells, all the time? Trends in molecular medicine. 2012;18:509-515

18. Smith SS. Female sex steroid hormones: From receptors to networks to performance-actions on the sensorimotor system. Progress in Neurobiology. 1994;44:55-86

19. Dickson RB, Stancel GM. Estrogen receptor-mediated processes in normal and cancer cells. Journal of The National Cancer Institute. Monographs. 2000:135145

20. Chuffa LG, Lupi-Junior LA, Costa AB, Amorim JP, Seiva FR. The role of sex hormones and steroid receptors on female reproductive cancers. Steroids. 2017;118:93-108

21. Mueck AO, Seeger H. 2-methoxyestradiol-biology and mechanism of action. Steroids. 2010;75:625-631 
22. Schumacher G, Neuhaus P. The physiological estrogen metabolite 2-methoxyestradiol reduces tumor growth and induces apoptosis in human solid tumors. Journal of Cancer Research and Clinical Oncology. 2001;127:405-410

23. Li L, Bu S, Backstrom T, Landstrom M, Ulmsten U, Fu X. Induction of apoptosis and $\mathrm{G} 2 / \mathrm{G}$ arrest by 2 -methoxyestradiol in human cervical cancer HeLaS3 cells. Anticancer Research. 2004;24:873-880

24. Mooberry SL. Mechanism of action of 2-methoxyestradiol: New developments. Drug Resistance Updates. 2003;6:355-361

25. Visagie M, Theron A, Mqoco T, Vieira W, Prudent R, Martinez A, et al. Sulphamoylated 2-methoxyestradiol analogues induce apoptosis in adenocarcinoma cell lines. PloS One. 2013;8:e71935

26. Fu J, Yang Y, Zhang XW, Mao WJ, Zhang ZM, Zhu HL. Discovery of 1hbenzo[d][1,2,3]triazol-1-yl 3,4,5-trimethoxybenzoate as a potential antiproliferative agent by inhibiting histone deacetylase. Bioorganic \& Medicinal Chemistry. 2010;18:8457-8462

27. Bhat BA, Reddy PB, Agrawal SK, Saxena AK, Kumar HM, Qazi GN. Studies on novel 4beta-[(4-substituted)-1,2,3-triazol-1-yl] podophyllotoxins as potential anticancer agents. European Journal of Medicinal Chemistry. 2008;43:2067-2072

28. Frank E, Molnar J, Zupko I, Kadar Z, Wolfling J. Synthesis of novel steroidal 17alpha-triazolyl derivatives via $\mathrm{Cu}(\mathrm{I})$-catalyzed azide-alkyne cycloaddition, and an evaluation of their cytotoxic activity in vitro. Steroids. 2011;76:1141-1148

29. Molnar J, Frank E, Minorics R, Kadar Z, Ocsovszki I, Schonecker B, et al. A click approach to novel D-ring-substituted 16alpha-triazolylestrone derivatives and characterization of their antiproliferative properties. PloS One. 2015;10:e0118104

30. Mernyak E, Fiser G, Szabo J, Bodnar B, Schneider G, Kovacs I, et al. Synthesis and in vitro antiproliferative evaluation of $\mathrm{D}$-secooxime derivatives of 13 beta- and 13alpha-estrone. Steroids. 2014;89:47-55

31. Petrovic JA, Pejanovic VM, Miljkovic DA, Hranisavljevic JT. Synthesis and estrogen activity screening of some new D-secoestrone derivatives. Steroids. 1990;55:276-278

32. Jovanovic-Santa SS, Petri ET, Klisuric OR, Szecsi M, Kovacevic R, Petrovic JA. Antihormonal potential of selected D-homo and D-seco estratriene derivatives. Steroids. 2015;97:45-53

33. Jovanovic-Santa S, Petrovic J, Andric S, Kovacevic R, Durendic E, Sakac M, et al. Synthesis, structure, and screening of estrogenic and antiestrogenic activity of new 3,17-substituted-16,17-seco-estratriene derivatives. Bioorganic Chemistry. 2003;31:475-484

34. Minorics R, Bozsity N, Wolfling J, Mernyak E, Schneider G, Marki A, et al. Antiproliferative effect of normal and 13-epi-D-homoestrone and their 3-methyl ethers on human reproductive cancer cell lines. The Journal of Steroid Biochemistry and Molecular Biology. 2012;132:168-175

35. Mernyak E, Szabo J, Bacsa I, Huber J, Schneider G, Minorics R, et al. Syntheses and antiproliferative effects of D-homo- and D-secoestrones. Steroids. 2014;87:128-136

36. Szabo J, Jerkovics N, Schneider G, Wolfling J, Bozsity N, Minorics R, et al. Synthesis and in vitro antiproliferative evaluation of C-13 epimers of triazolyl-Dsecoestrone alcohols: The first potent 13alpha-D-secoestrone derivative. Molecules. 2016;21 
37. Mosmann T. Rapid colorimetric assay for cellular growth and survival: Application to proliferation and cytotoxicity assays. Journal of Immunological Methods. 1983;65:55-63

38. Fritzer-Szekeres M, Savinc I, Horvath Z, Saiko P, Pemberger M, Graser G, et al. Biochemical effects of piceatannol in human HL-60 promyelocytic leukemia cells--synergism with Ara-c. International Journal of Oncology. 2008;33:887-892

39. Vermes I, Haanen C, Reutelingsperger C. Flow cytometry of apoptotic cell death. Journal of Immunological Methods. 2000;243:167-190

40. Juan G, Traganos F, James WM, Ray JM, Roberge M, Sauve DM, et al. Histone $\mathrm{H} 3$ phosphorylation and expression of cyclins $\mathrm{A}$ and $\mathrm{B} 1$ measured in individual cells during their progression through G2 and mitosis. Cytometry. 1998;32:71-77

41. Jordan MA, Wendell K, Gardiner S, Derry WB, Copp H, Wilson L. Mitotic block induced in HeLa cells by low concentrations of paclitaxel (taxol) results in abnormal mitotic exit and apoptotic cell death. Cancer Research. 1996;56:816825

42. Shi T, Mazumdar T, Devecchio J, Duan ZH, Agyeman A, Aziz M, et al. Cdna microarray gene expression profiling of hedgehog signaling pathway inhibition in human colon cancer cells. PloS One. 2010;5

43. Bellanger S, de Gramont A, Sobczak-Thepot J. Cyclin B2 suppresses mitotic failure and DNA re-replication in human somatic cells knocked down for both cyclins B1 and B2. Oncogene. 2007;26:7175-7184

44. Takemasa I, Yamamoto H, Sekimoto M, Ohue M, Noura S, Miyake Y, et al. Overexpression of cdc $25 \mathrm{~b}$ phosphatase as a novel marker of poor prognosis of human colorectal carcinoma. Cancer Research. 2000;60:3043-3050

45. Lau WS, Chen T, Wong YS. Allyl isothiocyanate induces G2/M arrest in human colorectal adenocarcinoma SW620 cells through down-regulation of cdc25b and cdc25c. Molecular Medicine Reports. 2010;3:1023-1030

46. Minorics R, Bozsity N, Molnar J, Wolfling J, Mernyak E, Schneider G, et al. A molecular understanding of D-homoestrone-induced G2/M cell cycle arrest in HeLa human cervical carcinoma cells. Journal of Cellular and Molecular Medicine. 2015;19:2365-2374

47. Lee CH, Lim H, Moon S, Shin C, Kim S, Kim BJ, et al. Novel anticancer agent, benzyldihydroxyoctenone, isolated from streptomyces sp. Causes G1 cell cycle arrest and induces apoptosis of HeLa cells. Cancer science. 2007;98:795-802

48. Behrens J, Kameritsch P, Wallner S, Pohl U, Pogoda K. The carboxyl tail of cx43 augments p38 mediated cell migration in a gap junction-independent manner. European Journal of Cell Biology. 2010;89:828-838

49. Mallmann P, Beckmann MW, Emons G. Innovations in cervical and endometrial cancer. Geburtshilfe und Frauenheilkunde. 2013;73:908-910

50. Berenyi A, Minorics R, Ivanyi Z, Ocsovszki I, Ducza E, Thole H, et al. Synthesis and investigation of the anticancer effects of estrone-16-oxime ethers in vitro. Steroids. 2013;78:69-78

51. Kaur R, Kaur G, Gill RK, Soni R, Bariwal J. Recent developments in tubulin polymerization inhibitors: An overview. European Journal of Medicinal Chemistry. 2014;87:89-124

52. Gheorgheosu D, Duicu O, Dehelean C, Soica C, Muntean D. Betulinic acid as a potent and complex antitumor phytochemical: A minireview. Anti-Cancer Agents in Medicinal Chemistry. 2014;14:936-945 
53. Yang SJ, Liu MC, Xiang HM, Zhao Q, Xue W, Yang S. Synthesis and in vitro antitumor evaluation of betulin acid ester derivatives as novel apoptosis inducers. European Journal of Medicinal Chemistry. 2015;102:249-255

54. Jonnalagadda SC, Corsello MA, Sleet CE. Betulin-betulinic acid natural product based analogs as anti-cancer agents. Anti-Cancer Agents in Medicinal Chemistry. 2013;13:1477-1499

55. Bednarczyk-Cwynar B, Ruszkowski P, Bobkiewicz-Kozlowska T, Zaprutko L. Oleanolic acid a-lactams inhibit the growth of HeLa, KB, MCF-7 and HEP-G2 cancer cell lines at micromolar concentrations. Anti-Cancer Agents in Medicinal Chemistry. 2015

56. Wu J, Yang C, Guo C, Li X, Yang N, Zhao L, et al. SZC015, a synthetic oleanolic acid derivative, induces both apoptosis and autophagy in MCF-7 breast cancer cells. Chemico-Biological Interactions. 2015

57. Liu J, Wu N, Ma LN, Zhong JT, Liu G, Zheng LH, et al. P38 mapk signaling mediates mitochondrial apoptosis in cancer cells induced by oleanolic acid. Asian Pacific Journal of Cancer Prevention : APJCP. 2014;15:4519-4525

58. Sun H, Lv C, Yang L, Wang Y, Zhang Q, Yu S, et al. Solanine induces mitochondria-mediated apoptosis in human pancreatic cancer cells. BioMed Research International. 2014;2014:805926

59. Ji YB, Gao SY, Ji CF, Zou X. Induction of apoptosis in HEP-G2 cells by solanine and bcl-2 protein. Journal of Ethnopharmacology. 2008;115:194-202

60. Choi SH, Lee SH, Kim HJ, Lee IS, Kozukue N, Levin CE, et al. Changes in free amino acid, phenolic, chlorophyll, carotenoid, and glycoalkaloid contents in tomatoes during 11 stages of growth and inhibition of cervical and lung human cancer cells by green tomato extracts. Journal of Agricultural And Food Chemistry. 2010;58:7547-7556

61. Minorics R, Szekeres T, Krupitza G, Saiko P, Giessrigl B, Wolfling J, et al. Antiproliferative effects of some novel synthetic solanidine analogs on HL-60 human leukemia cells in vitro. Steroids. 2011;76:156-162

62. Sunassee SN, Ransom T, Henrich CJ, Beutler JA, Covell DG, McMahon JB, et al. Steroidal alkaloids from the marine sponge corticium niger that inhibit growth of human colon carcinoma cells. Journal of Natural Products. 2014;77:2475-2480

63. Nesher M, Shpolansky U, Rosen H, Lichtstein D. The digitalis-like steroid hormones: New mechanisms of action and biological significance. Life Sciences. 2007;80:2093-2107

64. Khan MI, Chesney JA, Laber DA, Miller DM. Digitalis, a targeted therapy for cancer? The American Journal of The Medical Sciences. 2009;337:355-359

65. Slingerland M, Cerella C, Guchelaar HJ, Diederich M, Gelderblom H. Cardiac glycosides in cancer therapy: From preclinical investigations towards clinical trials. Investigational New Drugs. 2013;31:1087-1094

66. Choi HJ, Zhu BT. Critical role of cyclin b1/cdc2 up-regulation in the induction of mitotic prometaphase arrest in human breast cancer cells treated with 2-methoxyestradiol. Biochimica et Biophysica Acta. 2012;1823:1306-1315

67. Li L, Heldin NE, Grawe J, Ulmsten U, Fu X. Induction of apoptosis or necrosis in human endometrial carcinoma cells by 2-methoxyestradiol. Anticancer Research. 2004;24:3983-3990

68. Stander BA, Marais S, Vorster CJ, Joubert AM. In vitro effects of 2-methoxyestradiol on morphology, cell cycle progression, cell death and gene expression changes in the tumorigenic MCF-7 breast epithelial cell line. The Journal of Steroid Biochemistry and Molecular Biology. 2010;119:149-160 
69. MacCarthy-Morrogh L, Townsend PA, Purohit A, Hejaz HAM, Potter BVL, Reed MJ, et al. Differential effects of estrone and estrone-3-o-sulfamate derivatives on mitotic. Arrest, apoptosis, and microtubule assembly in human breast cancer cells. Cancer Research. 2000;60:5441-5450

70. Anstead GM, Carlson KE, Katzenellenbogen JA. The estradiol pharmacophore: Ligand structure-estrogen receptor binding affinity relationships and a model for the receptor binding site. Steroids. 1997;62:268-303

71. Jovanović-Šanta SS, Andrić S, Andrić N, Bogdanović G, Petrović JA. Evaluation of biological activity of new hemiesters of 17-hydroxy-16,17-secoestra-1,3,5(10)triene-16-nitrile. Medicinal Chemistry Research. 2010;20:1102-1110

72. Szabo J, Pataki Z, Wolfling J, Schneider G, Bozsity N, Minorics R, et al. Synthesis and biological evaluation of 13alpha-estrone derivatives as potential antiproliferative agents. Steroids. 2016;113:14-21

73. Hougardy BM, van der Zee AG, van den Heuvel FA, Timmer T, de Vries EG, de Jong S. Sensitivity to Fas-mediated apoptosis in high-risk HPV-positive human cervical cancer cells: Relationship with Fas, caspase-8, and bid. Gynecologic Oncology. 2005;97:353-364

74. Aguilar-Lemarroy A, Kirchhoff S, Whitaker N, Gariglio P, zur Hausen H, Krammer PH, et al. Differential sensitivity of human papillomavirus type $16(+)$ and type $18(+)$ cervical carcinoma cells to cd95-mediated apoptosis. International Journal of Cancer. 2001;93:823-831

75. Lee ST, Lee JY, Han CR, Kim YH, Jun do Y, Taub D, et al. Dependency of 2-methoxyestradiol-induced mitochondrial apoptosis on mitotic spindle network impairment and prometaphase arrest in human jurkat $\mathrm{T}$ cells. Biochemical Pharmacology. 2015;94:257-269

76. Jourdain L, Curmi P, Sobel A, Pantaloni D, Carlier MF. Stathmin: A tubulinsequestering protein which forms a ternary T2S complex with two tubulin molecules. Biochemistry. 1997;36:10817-10821

77. Cassimeris L. The oncoprotein 18/stathmin family of microtubule destabilizers. Current Opinion in Cell Biology. 2002;14:18-24

78. Rubin CI, Atweh GF. The role of stathmin in the regulation of the cell cycle. Journal of Cellular Biochemistry. 2004;93:242-250

79. Peyrat JF, Brion JD, Alami M. Synthetic 2-methoxyestradiol derivatives: Structure-activity relationships. Current Medicinal Chemistry. 2012;19:4142-4156

80. Bhalla KN. Microtubule-targeted anticancer agents and apoptosis. Oncogene. 2003;22:9075-9086

81. Yamaguchi H, Wyckoff J, Condeelis J. Cell migration in tumors. Current Opinion in Cell Biology. 2005;17:559-564

82. Krakhmal NV, Zavyalova MV, Denisov EV, Vtorushin SV, Perelmuter VM. Cancer invasion: Patterns and mechanisms. Acta Naturae. 2015;7:17-28

83. Simpson CD, Anyiwe K, Schimmer AD. Anoikis resistance and tumor metastasis. Cancer Letters. 2008;272:177-185

84. Polacheck WJ, Zervantonakis IK, Kamm RD. Tumor cell migration in complex microenvironments. Cellular and Molecular Life Sciences. 2013;70:1335-1356

85. Huang Y, Li J, Xiang L, Han D, Shen X, Wu X. 17beta-oestradiol activates proteolysis and increases invasion through phosphatidylinositol 3-kinase pathway in human cervical cancer cells. European Journal of Obstetrics, Gynecology, and Reproductive Biology. 2012;165:307-312

86. Guo RX, Wei LH, Tu Z, Sun PM, Wang JL, Zhao D, et al. 17 beta-estradiol activates PI3K/AKT signaling pathway by estrogen receptor (ER)-dependent and 
ER-independent mechanisms in endometrial cancer cells. The Journal of Steroid Biochemistry and Molecular Biology. 2006;99:9-18

87. Hua K, Feng W, Cao Q, Zhou X, Lu X, Feng Y. Estrogen and progestin regulate metastasis through the $\mathrm{PI} 3 \mathrm{~K} / \mathrm{AKT}$ pathway in human ovarian cancer. International Journal of Oncology. 2008;33:959-967

88. Lin $\mathrm{HL}$, Yang $\mathrm{MH}, \mathrm{Wu} \mathrm{CW}$, Chen PM, Yang YP, Chu YR, et al. 2-methoxyestradiol attenuates phosphatidylinositol 3-kinase/akt pathwaymediated metastasis of gastric cancer. International Journal of Cancer. 2007;121:2547-2555

89. Sattler M, Quinnan LR, Pride YB, Gramlich JL, Chu SC, Even GC, et al. 2-methoxyestradiol alters cell motility, migration, and adhesion. Blood. 2003;102:289-296

90. Stander BA, Joubert F, Tu C, Sippel KH, McKenna R, Joubert AM. In vitro evaluation of ese-15-ol, an estradiol analogue with nanomolar antimitotic and carbonic anhydrase inhibitory activity. PloS One. 2012;7:e52205 


\section{ACKNOWLEDGEMENTS}

I would like to express my special thanks to my supervisor, István Zupkó $\mathrm{PhD}$. the head of the Department of Pharmadynamics and Biopharmacy, for his guidance of my work, his support and his useful advices in my experimental work. I am also grateful to Róbert Gáspár PhD. the earlier head of the Department of Pharmacodynamics and Biopharmacy for providing me with the possibility to work in this department.

I am particularly thankful to my supervisor, Renáta Minorics $\mathrm{PhD}$., who was always there for me, even in the busiest times, who introduced me to the world of research and inspired me to start my scientific work. Her inspiration, encouragement and experimental advices made priceless contribution to my work.

I am also grateful to Prof. Chin-Chung Wu from the Graduate Institute of Natural Products (Kaohsiung Medical University) for his support, who made it possible to perform a part of my work in his laboratory and Prof. Hui-Chun Wang, for her help and advices.

I express my gratitude for our collaborating partners, first of all for Erzsébet Mernyák PhD. and Prof. János Wölfling and his colleagues in the Department of Organic Chemistry (University of Szeged) for the design and synthesis of the steroid compounds. I also very grateful for Imre Ocsovszki from the Department of Biochemistry (University of Szeged) for his help in flow cytometry.

I express my gratitude for all my colleagues and friends in the Department of Pharmacodynamics and Biopharmacy and in the Kaohsiung Medical University for creating a supportive and pleasant atmosphere. I thank to Péter Bérdi for his technical assistance in my experimental work. I'm really grateful for my dear Emily (Ching-Ying Kuo) and Jing Ru Liu for their help during my study in Taiwan.

I gratefully acknowledge the financial support from Talentum Fund of Gedeon Richter Plc. through my PhD study, from Campus Hungary Scholarship, which made the opportunity to spend six months in Taiwan, and for The New National Excellence Program of the Ministry of Human Capacities.

I am deeply grateful for my love for his patience and support throughout my studies, and my friends and family for their encouragement and love. 
ANNEX 
I. 


\title{
Mechanism of antiproliferative action of a new D-secoestrone-triazole derivative in cervical cancer cells and its effect on cancer cell motility
}

\author{
Noémi Bózsity ${ }^{\mathrm{a}}$, Renáta Minorics ${ }^{\mathrm{a}}$, Johanna Szabób ${ }^{\mathrm{b}}$ Erzsébet Mernyák ${ }^{\mathrm{b}}$, \\ István Zupkóa,* \\ a Department of Pharmacodynamics and Biopharmacy, University of Szeged, Eötvös u. 6, H-6720 Szeged, Hungary

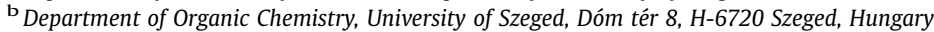 \\ c Graduate Institute of Natural Products, Kaohsiung Medical University, Kaohsiung, Taiwan \\ ${ }^{\mathrm{d}}$ Department of Biochemistry, University of Szeged, Dóm tér 9, H-6720 Szeged, Hungary
} Gyula Schneider ${ }^{\mathrm{b}}$, János Wölfling ${ }^{\mathrm{b}}$, Hui-Chun Wang ${ }^{\mathrm{c}}$, Chin-Chung $\mathrm{Wu}^{\mathrm{c}}$, Imre Ocsovszki ${ }^{\mathrm{d}}$,

\section{A R T I C L E I N F O}

\section{Article history:}

Received 4 April 2016

Received in revised form 24 June 2016

Accepted 27 June 2016

Available online 27 June 2016

\section{Keywords:}

Antiproliferative effect

D-Secoestrone-triazole

G2/M phase arrest

Apoptosis

Tubulin polymerization

Cell migration and invasion

\section{A B S T R A C T}

Cervical cancer is the fourth most frequently diagnosed tumor and the fourth leading cause of cancer death in females worldwide. Cervical cancer is predominantly related with human papilloma virus (HPV) infection, with the most oncogenic types being HPV-18 and -16. Our previous studies demonstrated that some D-secoestrone derivatives exert pronounced antiproliferative activity. The aim of the current investigation was to characterize the mechanism of action of D-secoestrone-triazole (D-SET) on three cervical cancer cell lines with different pathological backgrounds.

The growth-inhibitory effects of D-SET were determined by a standard MTT assay. We have found that D-SET exerts a pronounced growth-inhibitory effect on HPV 18-positive HeLa and HPV-negative C-33 A cells, but it has no substantial inhibitory activity on HPV 16-positive SiHa or on intact fibroblast MRC-5 cell lines. After $24 \mathrm{~h}$ incubation, cells showed the morphological and biochemical signs of apoptosis determined by fluorescent double staining, flow cytometry and caspase- 3 activity assay. Besides the elevation of the ratio of cells in the subG1 phase, flow cytometric analysis revealed a cell cycle arrest at G2/M in both HeLa and C-33 A cell lines. To distinguish the G2/M cell population immunocytochemical flow cytometric analysis was performed on HeLa cells. The results show that D-SET significantly increases the ratio of phosphorylated histone $\mathrm{H3}$, indicating cell accumulation in the M phase. Additionally, D-SET significantly increased the maximum rate of microtube formation measured by an in vitro tubulin polymerization assay. Besides its direct antiproliferative activity, the antimigratory property of D-SET has been investigated. Our results demonstrate that D-SET significantly inhibits the migration and invasion of HeLa cells after $24 \mathrm{~h}$ incubation.

These results suggests that D-SET is a potent antiproliferative agent against HPV 16+ and HPV-negative cervical cancer cell lines, with an efficacious motility-inhibiting activity against HPV 16+ cells. Accordingly D-SET can be regarded as a potential drug candidate with a promising new mechanism of action among the antiproliferative steroids, potentially allowing for the design of novel anticancer agents. (c) 2016 Elsevier Ltd. All rights reserved.

\section{Introduction}

Cancer is one of the major health problems worldwide. In 2012, around 8.2 million cancer deaths occurred and 14.1 million new

Abbreviations: D-SET, D-secoestrone-triazole; HPV, Human Papilloma Virus; 2 ME, 2-methoxyestradiol; PAC, paclitaxel; Bid, BH3 interacting-domain death agonist; Bcl-2, B-cell CLL/lymphoma 2; FADD, Fas-Associated protein with Death Domain; DISC, death-inducing signalling complex.

* Corresponding author.

E-mail address: zupko@pharm.u-szeged.hu (I. Zupkó). cancer cases were detected. Cervical cancer is the fourth most frequently diagnosed cancer in women and the fourth leading cause of death worldwide, accounting for 527,600 new cases and 265,700 deaths in 2012 [1]. In agreement with these global cancer statistics, 58,300 new cervical cancer cases were diagnosed, and 13,400 cervical cancer death occurred in Europe in 2012, with 38,800 all new cases occurring in Central European countries. These data imply that cervical cancer was the fifth most common cancer in Europe, and the fourth most frequently diagnosed tumor type in Central Europe in 2012 [2]. Cervical cancer is predominantly related with human papilloma virus (HPV) infection, epidemiological studies indicating 
that more than 18 variants of HPV are associated with carcinogenesis, of which HPV-18 and -16 are responsible for approximately $50 \%$ and $20 \%$ of cervical cancerous cases, respectively [3,4]. In developed countries vaccination and screening methods are widely available, and the number of death cases have therefore decreased during the last few years, but at the same time cervical cancer is still the second most commonly diagnosed malignancy in less developed countries, nearly $90 \%$ of cervical cancer deaths occurring in those countries $[1,5]$. Vaccination is recommended under the age of 25 or before the initiation of sexual activity, because its effectiveness is highest before any exposure to HPV infection [6,7]. Women over 25 years and antivaccination groups in developed countries are therefore still compromised, and even malignant cervical lesions diagnosed in the early stage need rapid and aggressive cytotoxic treatment utilizing novel anticancer agents with a more tolerable side-effect profile.

Estrogens play important roles in the normal functions of both male and female reproductive systems, including the regulation of growth and differentiation [8]. 17 $\beta$-Estradiol increases the proliferation of its target cells in the reproductive system and also in gynecological tumors by stimulating RNA synthesis [9]. Besides this established fact, since the 1990's more and more experimental results have indicated that structural modifications of $17 \beta$-estradiol may lead to estrone analogs with antiproliferative activity. A-Ring-modified 2-methoxyestradiol (2-ME) is one of the first discovered antiproliferative metabolites without steroidal activity against several cancerous cell lines [10-15] owing to its apoptosis-activating, microtubule-disrupting, antimigratory and antiangiogenic effects [16]. On the basis of these results, many new derivatives with anticancer properties have been synthetized and analyzed. The majority of published studies have focused on substitutions in multiple positions of the steroid structure or ring modifications. Several sets of newly synthetized secoestrones have been reported which include modifications to avoid estrogenic activity through opening of their D-ring [17-19]. Our previous studies demonstrated that some D-secoestrone derivatives exert pronounced antiproliferative activity thanks to their influence on microtubule formation from tubulin dimers [20].

The triazole ring can be regarded as a pharmacophore when built onto a steroid and other types of skeletons in order to obtain innovative antiproliferative agents. Several nonsteroidal triazole derivatives are biologically active, including many that possess antiproliferative and proapoptotic properties [21-24]. The most frequent positions for substitution of the sterane skeleton are $\mathrm{C}-2$, C-3 and C-17. Moreover, steroids with a triazole moiety in different positions have also been revealed to exert potent growthinhibitory effects [25-29]. Furthermore, incorporating a triazole structure into the estrone skeleton may improve stability, solubility and bioavailability of the compound [30]. A recent study has shown that triazole substitution in position C-3 dramatically enhanced the antiproliferative activity of D-secooxime derivatives [31].

These promising results encouraged us to continue and extend our investigations of D-secoestrones. In view of the previously mentioned most active secoalcohol, new analogs have been designed and proliferation-inhibitory effects have been detected. As expected, the derivatives with triazole substituents demonstrated the most pronounced anticancer effect on several malignant tumor cell lines tested [32].

Besides the antiproliferative and proapoptotic capacities, an antimetastatic effect is another important characteristic in question during the investigation of the anticancer mechanism of new compounds. The presence of metastasis is highly associated with poor patient prognosis, and the most frequent cause of cancer death [33]. Metastasis formation is a complex, multistage process, including changes in cell adhesion, migration and invasion [33,34]. The antimetastatic activity of the anticancer compounds is a major highlight of tumor-specificity as antimetastatic drugs have no cytotoxic effect on intact cells (i.e. on cells without motility changes). Previous studies have revealed that $17 \beta$-estradiol may induce cell invasion via the PI3K signaling pathway in cervical [35], endometrial [36] and ovarian cancer [37] cell lines. In addition, it has been reported that the above-mentioned A-ring-modified estrogen metabolite, 2-ME, has an antimetastatic effect on several cancer cell lines [38,39]. Stander et al. have reported that another synthetic sulfamoylated estrogen analog also has an antimetastatic potential, associated with the acidotic microenvironmental conditions in tumors [40]. To date, there has been no detailed investigation of the effects of secoestrogens on cell motility.

The aim of the present study was to characterize the mechanism of action of D-secoestrone-triazole (D-SET), the most active member of a recently designed and synthetized Dsecoestrone library on three cervical cancer cell lines with different pathological backgrounds. Besides investigating its antiproliferative activity, we also examined the changes in nuclear morphology, the alterations in cell cycle progression, and the proapoptotic properties of the test compound. We also investigated its action on cell migration and invasion, to reveal D-SET's influence on cancer cells motility.

\section{Materials and methods}

\subsection{Chemicals}

D-SET was synthetized as described elsewhere [32]. Its chemical structure is presented in Fig. 1. All other chemicals and kits, if otherwise not specified, were purchased from Sigma Aldrich Ltd. (Budapest, Hungary).

\subsection{Cell cultures}

The human cervical cancer cell line HeLa (HPV 18+ adenocarcinoma) was purchased from ECACC (European Collection of Cell Cultures, Salisbury, UK), while SiHa (HPV 16+ squamous cell carcinoma) and C-33 A (HPV negative carcinoma) were purchased from ATCC (American Tissue Culture Collection, Manassas, Virginia, USA) [41]. The cells were grown in Dulbecco's Modified Eagle's Medium (DMEM) supplemented with 10\% heat-inactivated fetal calf serum (FCS), $1 \%$ non-essential aminoacids, and $1 \%$ penicillin-streptomycin. All media and supplements were obtained from Lonza Group Ltd. (Basel, Switzerland). The cells were maintained at $37{ }^{\circ} \mathrm{C}$ in humidified atmosphere containing $5 \% \mathrm{CO}_{2}$.

\subsection{Antiproliferative MTT assay}

The growth-inhibitory activity of D-SET was determined by standard MTT dye uptake methods on three cervical cancer cell lines with differences in HPV status: HeLa, C-33 A and SiHa cells.

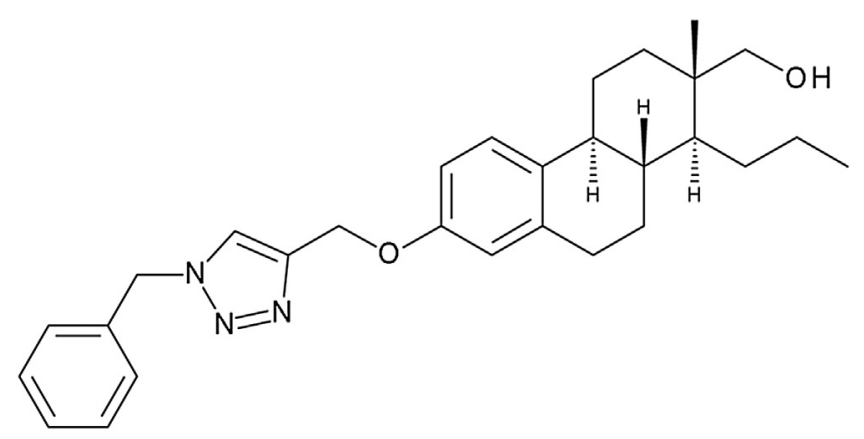

Fig. 1. Chemical structure of D-secoestrone-triazole (D-SET). 
Experiments were carried out in the same way as described previously [32]. Briefly, cells were plated into 96-well plates at a density of 5000 cells/well in the cases of HeLa and SiHa, and 10,000 cells/well in the case of C-33 A, and incubated with increasing concentrations of D-SET $(0.1-30.0 \mu \mathrm{M})$ under cell-culturing conditions. After incubation for $72 \mathrm{~h}, 5 \mathrm{mg} / \mathrm{ml}$ MTT (3-(4,5-dimethylthiazol-2-yl)-2,5-diphenyltetrazolium bromide) solution was added and the samples were incubated for another $4 \mathrm{~h}$. The precipitated formazan crystals were dissolved in dimethyl sulfoxide and the absorbance was measured at $545 \mathrm{~nm}$ with a microplate reader. Wells with untreated cells were utilized as control [42]. Cisplatin was used as a positive control in the same concentration range as the test compound. Sigmoidal dose-response curves were fitted to the measured points, and $\mathrm{IC}_{50}$ values were calculated by means of GraphPad Prism 5.01 (GraphPad Software, San Diego, CA, USA).

\subsection{Hoechst 33258-propidium iodide (HOPI) double staining}

HOPI staining was performed as described earlier [43] with minor modifications. HeLa and C-33 A cell lines were seeded in 96well plates, at a density of 3000-5000 cells/well. Cells were treated with increasing concentrations of the test compound in quintuple. After incubation for $24 \mathrm{~h}$, Hoechst 33258 (HO) and propidium iodide (PI) were added directly to the cells in final concentrations of $5 \mu \mathrm{g} / \mathrm{ml}$ and $3 \mu \mathrm{g} / \mathrm{ml}$, respectively. After incubation for $60 \mathrm{~min}$ at $37^{\circ} \mathrm{C}$ under $5 \% \mathrm{CO}_{2}$, cells were examined under a Nikon ECLIPSE TS100 fluorescence microscope (Nikon Instruments Europe B.V., Amstelveen, The Netherlands) equipped with appropriate filters for HO (excitation: $360 / 40 \mathrm{~nm}$ bandpass filter, emission: 460/ $50 \mathrm{~nm}$ bandpass filter and $400 \mathrm{~nm}$ dichromatic mirror) and PI (excitation: $500 / 20 \mathrm{~nm}$ bandpass filter, emission: $520 \mathrm{~nm}$ longpass filter and $515 \mathrm{~nm}$ dichromatic mirror). This method allows a distinction between early apoptosis and secondary necrosis based on the cells' nuclear morphology and the integrity of the membranes. of the solution of $\mathrm{HO}$ dye is known to permeate into the nuclei of all the cells, therefore the nuclei of all the living cells reflect a homogeneous blue staining, while in response to the apoptotic progress bright chromatin condensation and nuclear fragmentation can be observed. PI uptake indicates the loss of membrane integrity, and in the case of late-apoptosis or necrosis the cell nuclei are therefore stained red. To detect the form of cell death, two separate pictures were taken from the same field.

\subsection{Cell cycle analysis by flow cytometry}

To measure cellular DNA content, flow cytometric analysis was performed. HeLa and C-33 A cells were seeded into 6-well plates at a density of 300,000-400,000 cells/well. At $24 \mathrm{~h}$ after treatment, the cells were washed twice with cold phosphate-buffered saline (PBS), harvested with trypsin and centrifuged at $1500 \mathrm{rpm}$ for $10 \mathrm{~min}$. After a washing step, the cells were fixed in $1 \mathrm{ml}-20^{\circ} \mathrm{C} 70 \%$ ethanol for $30 \mathrm{~min}$. Samples were stained with $1.0 \mathrm{ml}$ dye solution containing $0.02 \mathrm{mg} / \mathrm{ml}$ RNAse A, $0.1 \mathrm{mg} / \mathrm{ml} \mathrm{PI}, 0.003 \mu \mathrm{l} / \mathrm{ml}$ Triton-X and $1.0 \mathrm{mg} /$ $\mathrm{ml}$ sodium citrate in distilled water, and the mixture was incubated in the dark for $60 \mathrm{~min}$ at room temperature. Cells were analyzed by a Partec CyFlow instrument (Partec GmbH, Münster, Germany). In each analysis, 20,000 events were recorded, and the percentages of the cells in the different cell cycle phases (subG1, G1, S and G2/M) were determined by using ModFit Software. The subG1 fraction was regarded as the apoptotic cell population [44].

\subsection{Distinction of G2 and M phases by specific flow cytometry}

To separate the G2/M population, M-phase-specific immunocytochemical flow cytometry was performed. HeLa cells were plated into 6 -well plates and allowed to proliferate for $48 \mathrm{~h}$. At $24 \mathrm{~h}$ after the treatment with $1.0 \mu \mathrm{M}$ test compound and $5 \mathrm{nM}$ paclitaxel as a positive control [45], cells were washed and harvested as described above (in Section 2.5). Cells were resuspended with PBS and a commercially available FlowCellect ${ }^{\mathrm{TM}}$ Bivariate Cell Cycle Kit for G2/M Analysis (Millipore Co., Billerica, MA, USA) was used. Briefly, cells were fixed with fixation buffer for $20 \mathrm{~min}$ at $4{ }^{\circ} \mathrm{C}$ and permeabilized with permeabilization buffer for 5 min at $4^{\circ} \mathrm{C}$. Cells were washed with $1 \mathrm{x}$ assay buffer and stained with anti-phospho-Histone H3 (Ser10) antibody conjugated with Alexa Fluor 488 at $4{ }^{\circ} \mathrm{C}$, for $1 \mathrm{~h}$ in the dark. Following another washing step, freshly prepared PI/RNase solution was added and allowed to stand in the dark for $30 \mathrm{~min}$ at room temperature. Samples were analyzed by the Partec CyFlow instrument. In each analysis, 20,000 events were recorded, and the data were analyzed using Flowing Software 2.5.1 (Cell Imaging Core, Turku Centre for Biotechnology, Turku, Finland). The phosphorylation of histone H3 at Ser10 correlates with the G2 to $M$ phase transition. This phosphorylation process is a prerequisite for chromatin condensation; it proceeds during the metaphase, whereas the dephosphorylation occurs rapidly at the end of the mitosis. The used antibody is therefore a reliable marker for the identification of cells specifically in the M phase [46].

\subsection{Determination of in situ caspase activity}

Caspase-3 is one of the most critical effector enzymes of apoptosis. To analyze the effects of caspase- 3 activation, a commercially available colorimetric assay (Casp-3-C) was performed. $10^{7}$ cells were seeded in tissue culture flasks. On the second day, the cells were treated with D-SET at concentrations of $0.3 \mu \mathrm{M}$ or $1.0 \mu \mathrm{M}$. After incubation for $24 \mathrm{~h}$, cells were counted, centrifuged and washed with PBS. The cells were resuspended in kit lysis buffer at a concentration of $10^{7}$ cells per $100 \mu \mathrm{l}$, and incubated on ice for $20 \mathrm{~min}$. The lysate was centrifuged and the supernatant was used. The protein concentration of the lysate was measured with the Pierce BCA Protein Assay Kit (Pierce Biotechnology, Rockford, IL, USA) and equal amounts of protein were used for the measurement. In accordance with the manufacturer's protocol, $5.0 \mu \mathrm{l}$ portions of treated and untreated cell lysates were incubated with $10 \mu$ l selective caspase- 3 substrate (acetyl-AspGlu-Val-Asp-p-nitroanilide) in a final volume of $100 \mu \mathrm{l}$ in assay buffer, in 96-well plates. After an overnight incubation at $37^{\circ} \mathrm{C}$, the absorbance of $p$-nitroaniline was measured at $405 \mathrm{~nm}$ with a microplate reader. Comparison of the absorbances of the $p$ nitroaniline from treated and untreated samples allowed determination of the fold increase in caspase- 3 activity.

\subsection{Tubulin polymerization assay}

The cell-independent direct effect of the test compound on tubulin polymerization was tested in vitro, using a commercially available Tubulin Polymerization Assay Kit (Cytoskeleton Inc., Denver, CO, USA), according to the manufacturer's recommendation. The concentration of paclitaxel was defined in the manufacturer's protocol, while the used concentration of the test compound was selected based on the $\mathrm{IC}_{50}$ values of PAC and D-SET. Briefly, $10 \mu \mathrm{l}$ of a $1 \mathrm{mM}$ solution of D-SET, and $10 \mu \mathrm{l}$ each of paclitaxel, and general tubulin buffer (as positive and negative controls) were placed on prewarmed UV transparent microplates. $100 \mu \mathrm{l}$ of $3.0 \mathrm{mg} / \mathrm{ml}$ tubulin in $80 \mathrm{mM}$ PIPES pH 6.9, $2 \mathrm{mM} \mathrm{MgCl}_{2}$, $0.5 \mathrm{mM}$ EGTA, $1 \mathrm{mM}$ GTP, and $10.2 \%$ glycerol were added to each sample, and the measurement was started immediately in a prewarmed UV spectrophotometer (SpectroStarNano, BMG Labtech, Ortenberg, Germany). A 50-min kinetic reaction was recorded to determine the absorbance of tubulin solution at $340 \mathrm{~nm}$ per min. 
For the statistical analysis, the maximum rate $\left(\mathrm{V}_{\max }\right.$, $\Delta$ absorbance/min) was calculated from the kinetic curve. $V_{\max }$ is the highest difference of the absorbance between two successive time points of the kinetic curve.

\subsection{Analysis of cell migration using the wound healing assay}

To analyze the migratory capacity of HeLa cells, the wound healing assay was used. The assay was performed with specific wound assay chambers (ibidi GmbH, Martinsried, Germany). HeLa cells were trypsinized and 35,000 cells $(100 \mu \mathrm{l}$ of 350,000 cells $/ \mathrm{ml}$ cell suspension) were seeded into each chamber of the inserts [47]. After an overnight incubation for appropriate cell attachment at $37^{\circ} \mathrm{C}$ under $5 \% \mathrm{CO}_{2}$, the culture insert was removed. A washing step with PBS was performed to remove nonadherent cells and debris. Cells were treated with increasing concentrations of the test compound in medium containing $1 \%$ FBS for $24 \mathrm{~h}$. Migration of the cells into the wound site was visualized by a phase-contrast inverted microscope (Axiovert 40, Zeiss, Thornwood, NY, US). Images were taken by a CCD camera at planned intervals to assess the wound closure. The rate of migration was calculated as the ratio of the wound closure in treated samples after $24 \mathrm{~h}$ and $0 \mathrm{~h}$, respectively as compared with the ratio of the wound closure in untreated control samples after $24 \mathrm{~h}$ and $0 \mathrm{~h}$, respectively.

\subsection{Analysis of cell invasion by using the Boyden chamber assay}

The invasion ability of HeLa cells was assessed by using the BD BioCoat Matrigel Invasion Chamber with an 8 micron pore size PET membrane with a thin layer of Matrigel Basement Matrix (BD Biosciences, Bedford, MA, USA) according to the instructions of the manufacturer. Briefly, HeLa cells were trypsinized, washed and resuspended in serum-free medium. A total of 50,000 cells were seeded into each top insert and 10\% FBS-containing medium was added into the bottom well as chemoattractant. After incubation for $24 \mathrm{~h}$ at $37^{\circ} \mathrm{C}$ under $5 \% \mathrm{CO}_{2}$, the culture insert was removed and non-invading cells were eliminated from the upper surface of the membrane by scrubbing with a cotton swab. The inserts were washed with PBS, fixed with cold methanol and stained with crystal violet solution. The invading, stained cells, a minimum of 8 fields per insert were counted under a phase-contrast inverted microscope. The rate of invasion was calculated from the invaded cell number of the treated samples as compared with the invaded cell number of untreated control samples.

\subsection{Statistical analysis}

For statistical evaluation of the experimental data, GraphPad Prism version 5.01 for Windows (GraphPad Software, San Diego, CA, USA) software was used. Statistical significance was assessed by one-way ANOVA with Dunnett post test for comparison of multiple groups. A $p$ value less than 0.05 was taken as significant.

\section{Results}

\subsection{Antiproliferative MTT assay}

The curves illustrating the growth-inhibition properties of the D-SET on the three different HPV status cervical carcinoma cell lines are presented in Fig. 2. The results show that D-SET exerts a pronounced growth-inhibitory effect on HeLa cells with a $1.12 \mu \mathrm{M}$ $\mathrm{IC}_{50}$ value and on C-33 A cells with a $1.77 \mu \mathrm{M} \mathrm{IC} \mathrm{C}_{50}$ value, but it has no substantial inhibitory potential on SiHa or MRC-5 $\left(\mathrm{IC}_{50}>30 \mu \mathrm{M}\right)$ [32] after $72 \mathrm{~h}$.

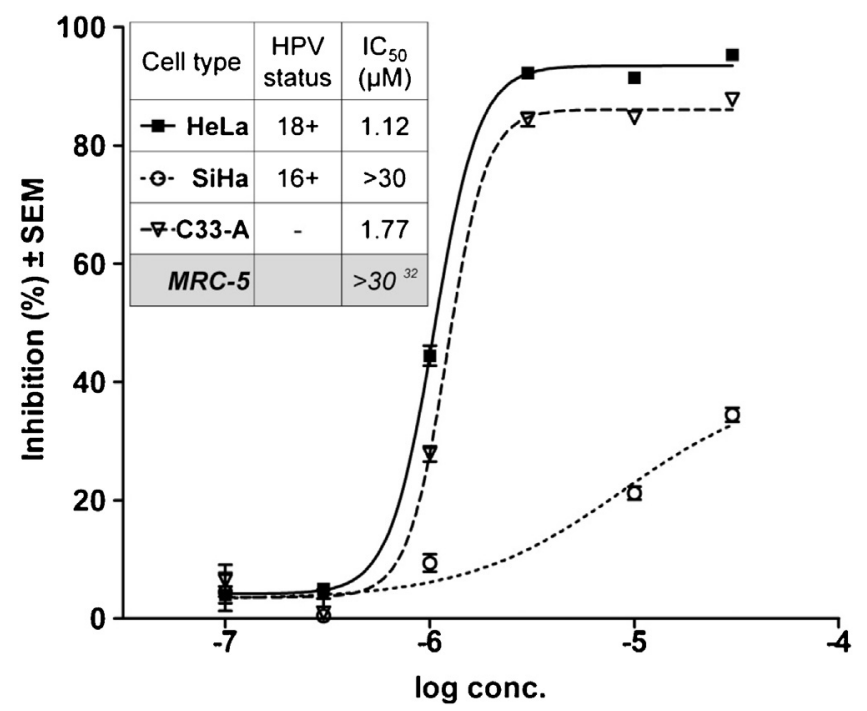

Fig. 2. D-SET inhibits proliferation of HeLa and C-33A, but not SiHa cell lines. Antiproliferative dose-response curves are presented as percentages of cell inhibition on HeLa, C-33A and SiHa cell lines after incubation for $72 \mathrm{~h}$, measured by MTT assay. Data are means $\pm S E M$, the calculated IC $_{50}$ values are from three separate experiments, $\mathrm{n}=5$.

\subsection{HOPI double staining}

Morphological changes observed in HeLa and C-33 A cells following D-SET treatment are shown in Fig. 3. Cells were treated with the test compound in concentrations of $0.1-3.0 \mu \mathrm{M}$ for $24 \mathrm{~h}$. The presence of living, early apoptotic and late-apoptotic or necrotic cells were distinguished according to cell morphology and membrane integrity. To detect the nature of cell death, two separate pictures from the same field were taken. For both cell lines the number of apoptotic cells increased after treatment for $24 \mathrm{~h}$ in a concentration-dependent manner relative to the untreated controls. At lower concentrations ( 0.1 and $0.3 \mu \mathrm{M})$, both HeLa and C-33A cells showed the signs of early apoptosis, whereas at the higher concentrations ( 1.0 and $3.0 \mu \mathrm{M})$, the loss of membrane integrity, and therefore increased rates of lateapoptotic or necrotic cells could be observed.

\subsection{Cell cycle analysis by flow cytometry}

On the basis of their antiproliferative property and morphological changes, the cell cycle phase distribution of the treated cells was determined (Fig. 4). HeLa and C-33 A cells were treated with $0.3 \mu \mathrm{M}, 1.0 \mu \mathrm{M}$ or $3.0 \mu \mathrm{M}$ D-SET for $24 \mathrm{~h}$, and the different cell populations were analyzed. The results in the two cell lines with different HPV status show a similar trend. The percentage of hypodiploid cells (subG1 phase) increased significantly after treatment with $1.0 \mu \mathrm{M}$ or $3.0 \mu \mathrm{M}$ of D-SET. Besides the increase of the apoptotic subG1 phase, a significant and concentrationdependent increase in the ratio of cells in the G2/M phase followed by a G1 phase reduction was established in both cell lines (Fig. 4), indicating a cell cycle blockade in the G2/M phase

\subsection{Distinction of G2 and M phases by specific flow cytometry}

We have decided to choose HeLa cells for our further experiments, due to the lower $\mathrm{IC}_{50}$ value of D-SET. To distinguish the G2/ $M$ cell population, immunocytochemical flow cytometric analysis was performed on HeLa cells. It revealed that $1.0 \mu \mathrm{M}$ D-SET significantly increased the ratio of phosphorylated histone $\mathrm{H} 3$ 
A $\square$ intact early apoptosis

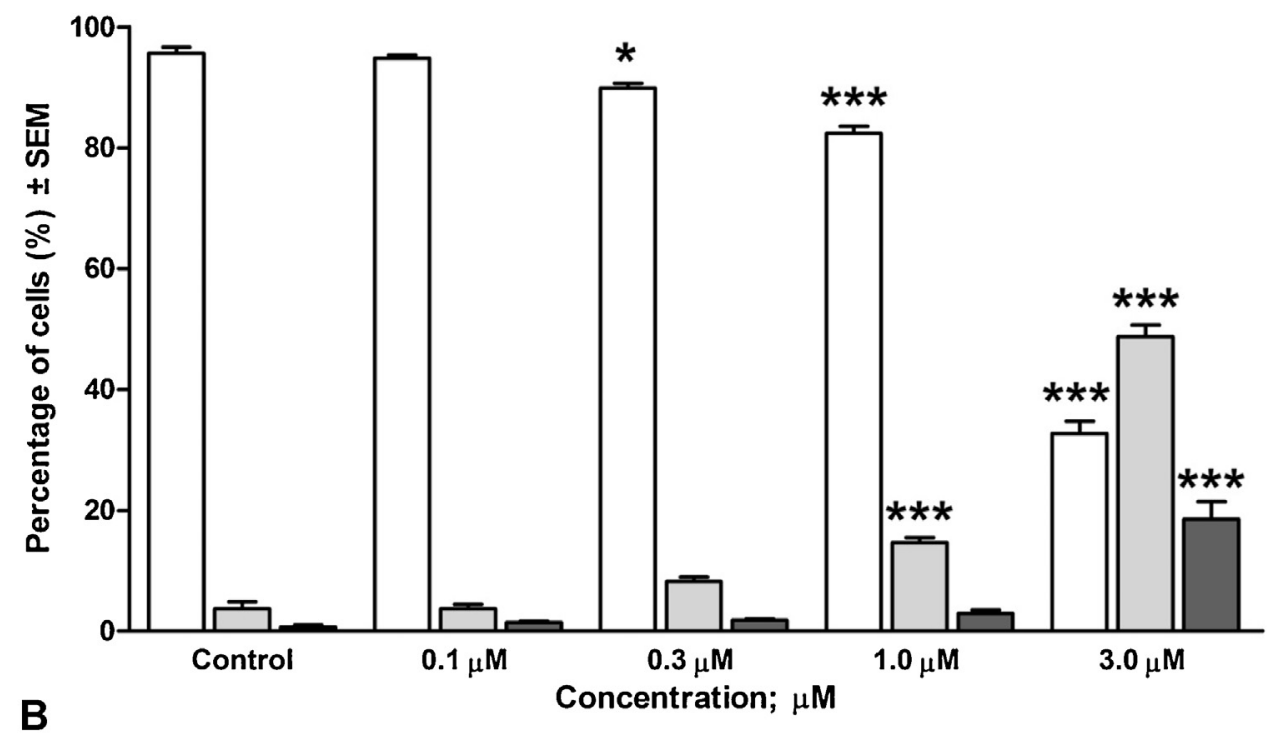

B

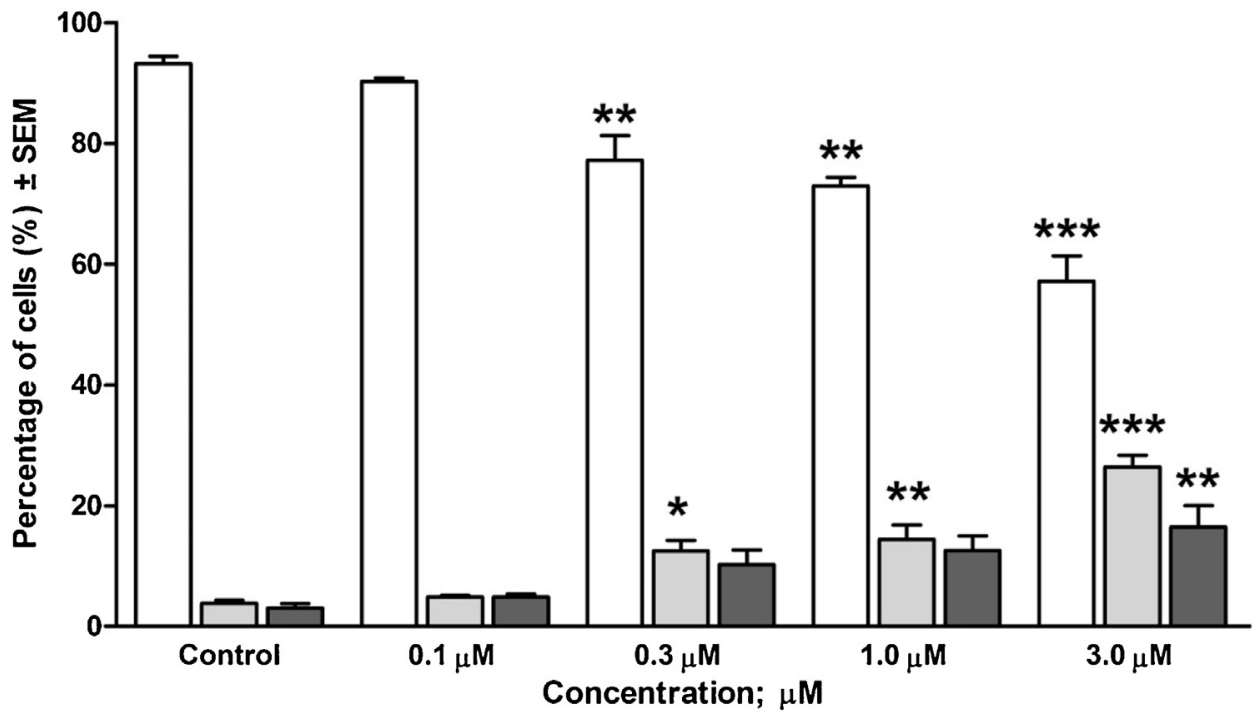

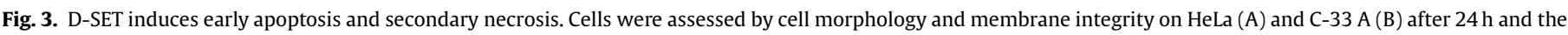

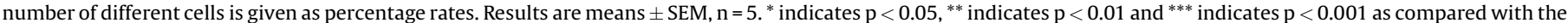
control cells. Non-significant changes are not indicated. Representative photos are presented as Supplementary figures.

protein at position Ser 10 (Fig. 5), compared with the untreated control cells, indicating cell accumulation in the $M$ phase after incubation for $24 \mathrm{~h}$. This effect is similar to that of the well-known mitotic blocking agent, paclitaxel.

\subsection{Determination of in situ caspase activity}

After considering the morphological and cell cycle changes, the activity of caspase-3, the major effector enzyme of apoptosis, was detected after treatment with $0.3 \mu \mathrm{M}$ or $1.0 \mu \mathrm{M}$ D-SET for $24 \mathrm{~h}$. The enzyme activity was significantly increased after incubation at each applied concentration (Fig. 6).

\subsection{Tubulin polymerization assay}

During the M phase, the equilibrium between the polymerization and degradation of microtubuli from tubulin dimers has an important role in cell division [48]. The direct effect of D-SET on tubulin polymerization is shown in Fig. 7. The kinetic curves indicate that $100 \mu \mathrm{M}$ D-SET accelerated tubulin polymerization in the growth phase and increased the overall polymer mass of the reaction (Fig. 7A), which was also reflected in the calculated $V_{\text {max }}$ values. The test compound significantly increased the maximum rate of microtube formation at $100 \mu \mathrm{M}$ concentration (100-fold of D-SET's IC 50 ),showing similar trend to $10 \mu \mathrm{M}$ paclitaxel (1000-fold of PAC's $I_{50}$ ), a well-known microtubule stabilizer (Fig. 7B).

\subsection{Analysis of cell migration using the wound healing assay}

Besides the direct antiproliferative activity, another important part of the mechanism of action can be the motility inhibiting property of the compound. Thus, migrating behavior of the cells was investigated by the wound healing assay. The untreated control HeLa cells closed around $60 \%$ of the wound area generated by the insert after $24 \mathrm{~h}$. On the contrary, D-SET-treated cells failed 


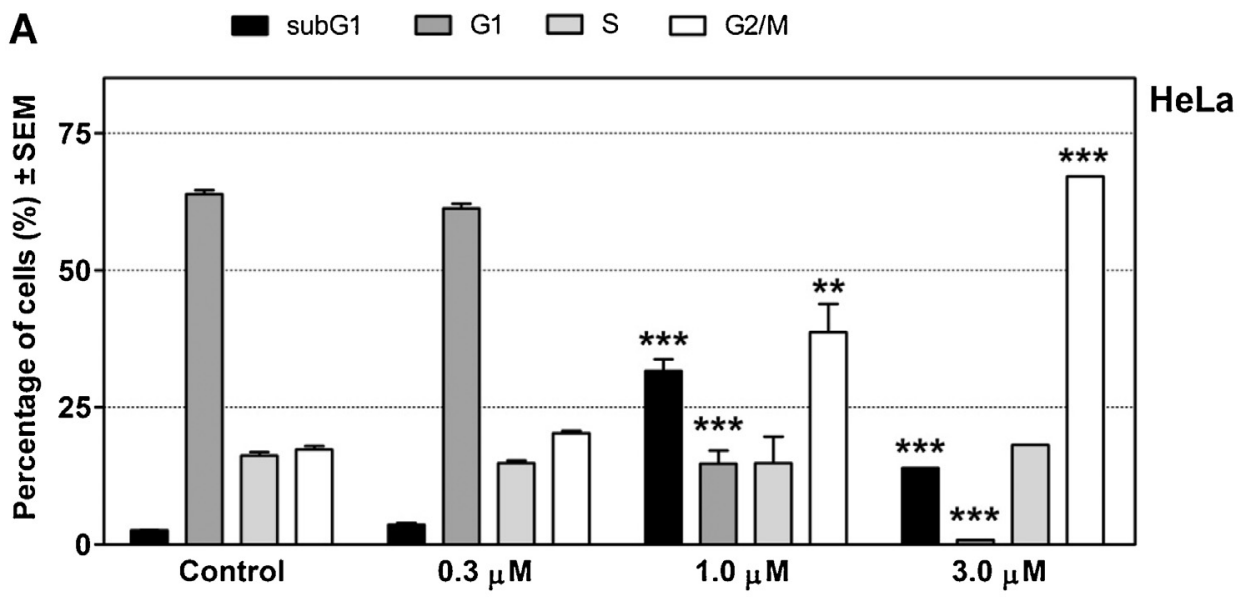

B

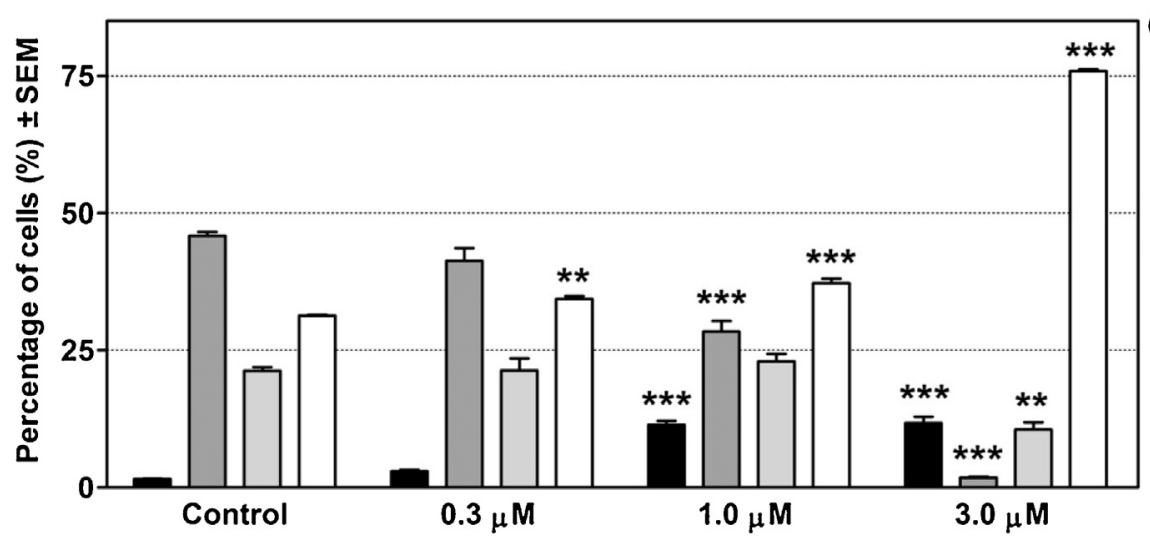

C-33 A

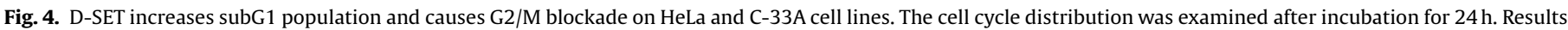

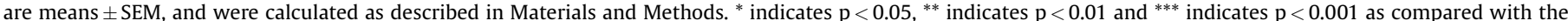
control cells. Non-significant changes are not indicated.

A

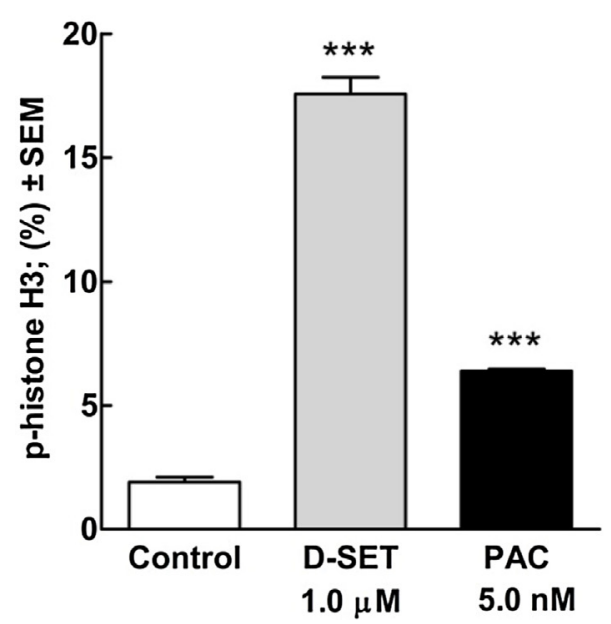

B
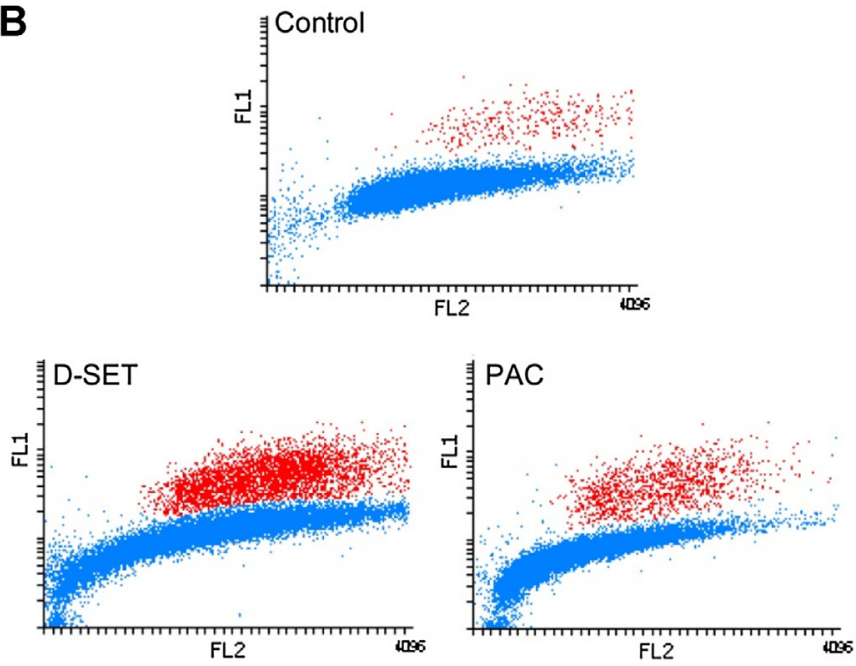

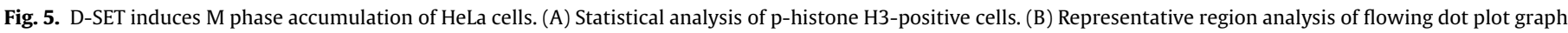

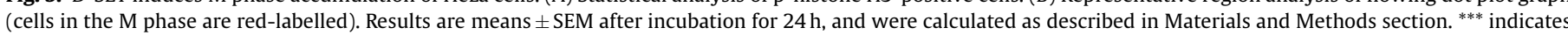
$\mathrm{p}<0.001$ as compared with the control cells. 


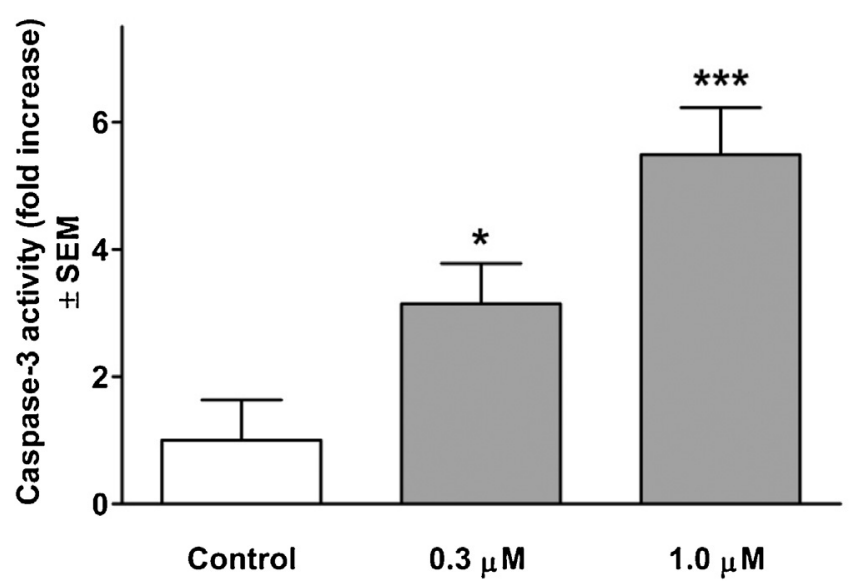

Fig. 6. D-SET increases in situ caspase-3 activity in HeLa cells. The results show the fold increases of the enzyme activity of the treated samples as compared with the untreated controls after $24 \mathrm{~h}$ incubation with the test compound. The data are means \pm SEM, $\mathrm{n}=3$. $^{*}$ indicates $\mathrm{p}<0.05$, ${ }^{* * *}$ indicates $\mathrm{p}<0.001$ as compared with the control cells.

to close the wound and inhibited the migration of HeLa cells in a concentration-dependent manner. Notably, $0.3 \mu \mathrm{M}$ D-SET induced wound closure in $30 \%$ of wound area, while 1.0 and $3.0 \mu \mathrm{M}$ solution of the test compound induced a wound closure covering only $10 \%$ of the wound area (Fig. 8), leading to the conclusion, that D-SET reaches its maximum antimigratory effect at a concentration of $1.0 \mu \mathrm{M}$.

\subsection{Analysis of cell invasion by using the Boyden chamber assay}

The anti-invasive effect of D-SET was examined with the Matrigel-coated Boyden chamber. The Matrigel Basement Matrix layer occludes the pores of the membrane, blocking the noninvasive cells from migrating through the membrane. On the other hand, it allows the invasive cells to detach and invade through the membrane. After incubation for $24 \mathrm{~h} \mathrm{D-SET} \mathrm{significantly} \mathrm{inhibited}$ the invasion of HeLa cells as compared with the untreated controls (Fig. 9). This inhibition was already present after the exposure of $0.1 \mu \mathrm{M}$ test compound, and became stronger as the concentration was raised.

\section{Discussion}

Natural and natural-related compounds are the most commonly used drugs worldwide; hence, the first anticancer agents with a steroid structure were of herbal origin [49-55]. Besides natural plant steroids, some endogenous steroid metabolites are also reported to be potent antiproliferative agents [10-16,56].

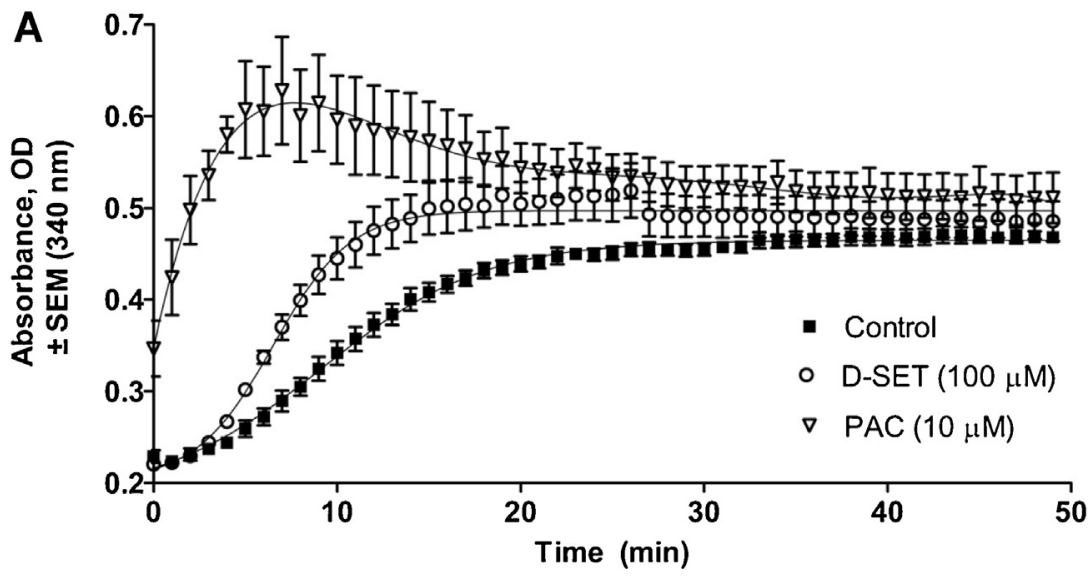

B

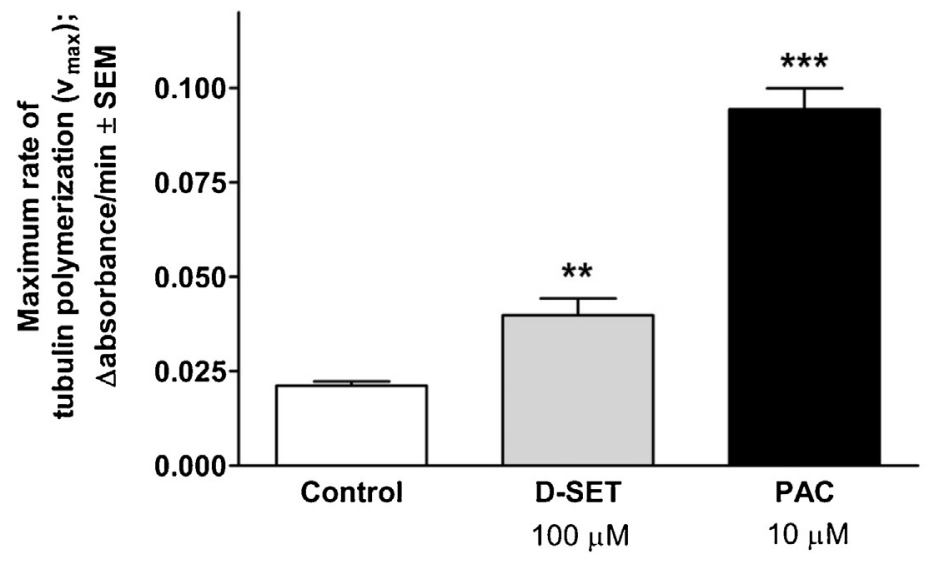

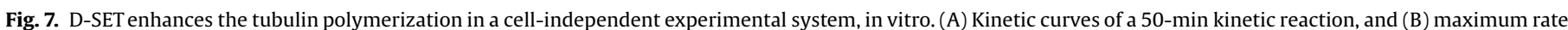

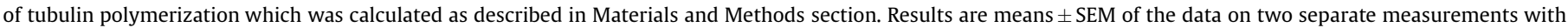
duplicates. ${ }^{* *}$ indicates $\mathrm{p}<0.01{ }^{* * *}$ indicates $\mathrm{p}<0.001$ as compared with the negative control samples. 
A

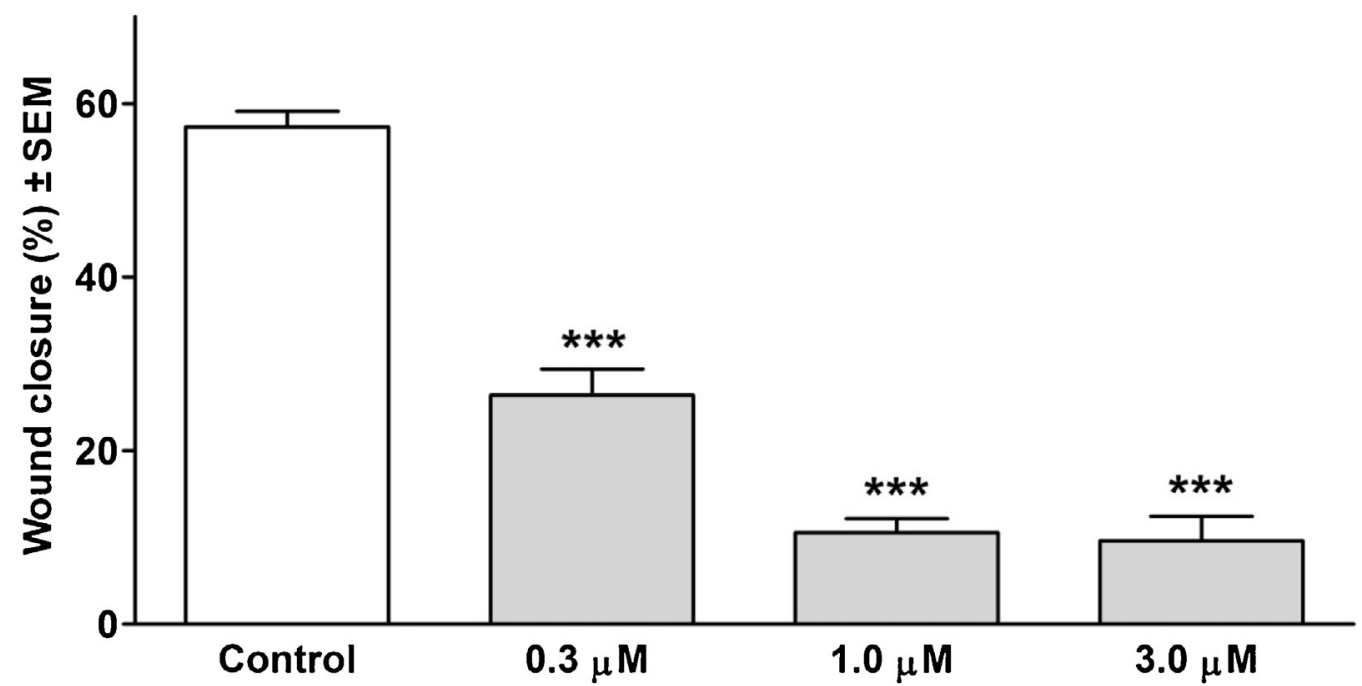

B

C

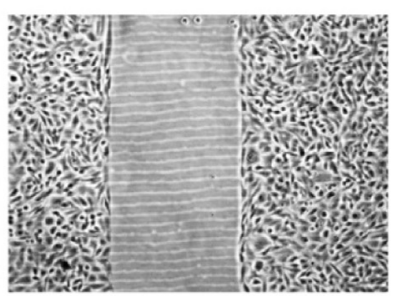

$\mathbf{O h}$

$24 \mathrm{~h}$

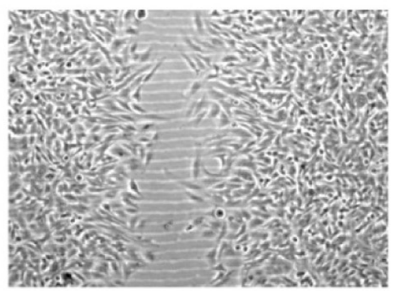

$0.3 \mu \mathrm{M}$
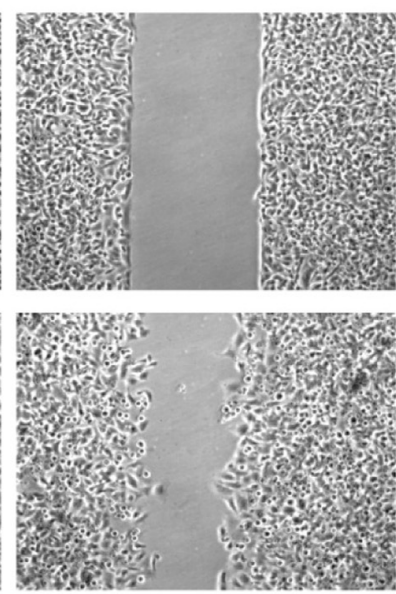

$1.0 \mu \mathrm{M}$
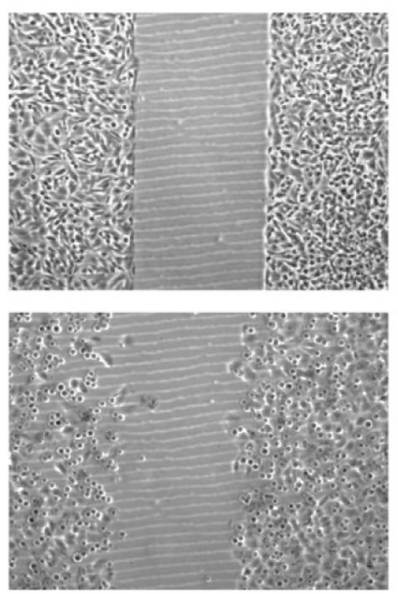

$3.0 \mu \mathrm{M}$
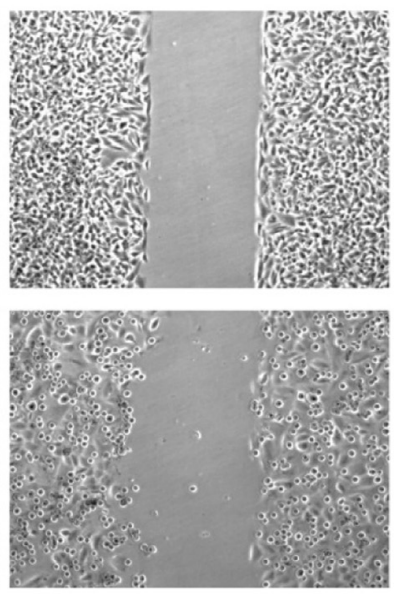

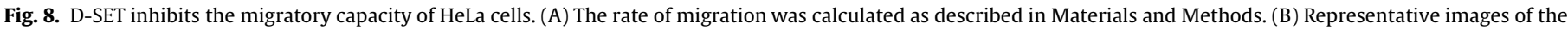

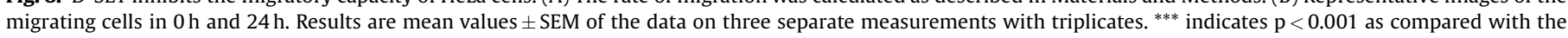
untreated control samples.

Active natural compounds and their metabolites play an important role for the design of novel, more effective drug candidates for synthetic chemistry. The conventional receptorbinding and activating capacity is an intriguing question of compounds with steroid structure in their expected therapeutic use. It has been described that D-homoestrone, does not exert estrogenic effect in an in vivo uterotrophic assay system [57]. A review of the literature, revealed data about a negative association between the opened D-ring and the estrogen receptor (ER)-binding capacity. Anstead et al. summarized the criteria for ER binding and concluded that the integrity of the D-ring is necessary for a high receptor affinity. Especially that $\mathrm{C} 14-\mathrm{C} 17$ are cavity vertices with a favorable interaction, and that the $\mathrm{C} 15-\mathrm{C} 16-\mathrm{C} 17$ crescent should be at the appropriate position, and therefore that the fragmentation of the D-ring in secoestradiol derivatives may lead to a decrease or total loss of affinity for estrogen-receptor [58]. Additionally, observations by Jovanovic-Santa et al. confirmed that numerous newly synthetized and investigated D-secoestrogen derivatives undergo a totally loss of estrogen activity [17-19,59].
Our previous studies demonstrated that D-ring modification in the estrogen structure can cause a potent antiproliferative effect in vitro $[20,32,57,60]$; we also reported about the considerable antitumor effects of several D-secoestrone derivatives in eight different reproductive cancer cell lines [32]. Among these analogs, a compound with a 3-triazole substituent (D-SET) was found to the most effective on cervical carcinoma cell lines, while it has no significant inhibitory effect on the non-cancerous human fetal lung fibroblast (MRC-5) cells. We also reported that the antiproliferative effectivity and tumor selectivity of D-SET is more potent than that of cisplatin [61], a drug regularly used in cervical tumor therapy [32]. In view of these data, we performed antiproliferative assays of D-SET on cervical cancer cell lines with differences in HPV status (HeLa, HPV 18+, SiHa, HPV 16+, C-33 A HPV negative). Our study revealed that D-SET may exert potent anticancer effects on HPVnegative and HPV18+ cervical cells, with a pronounced proaptotic activity as demonstrated by our HOPI double staining and flow cytometric cell cycle analysis, but it exhibits no antiproliferative effect on HPV16-infected SiHa cells. A possible explanation of why 
A

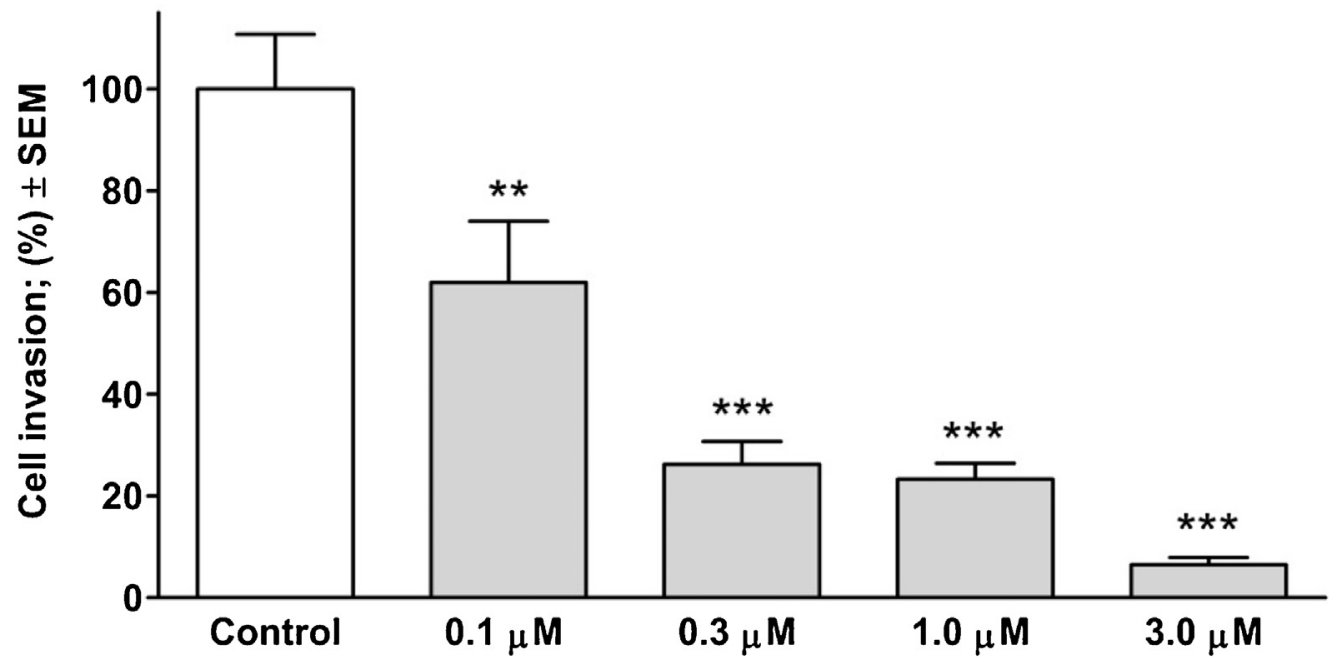

B
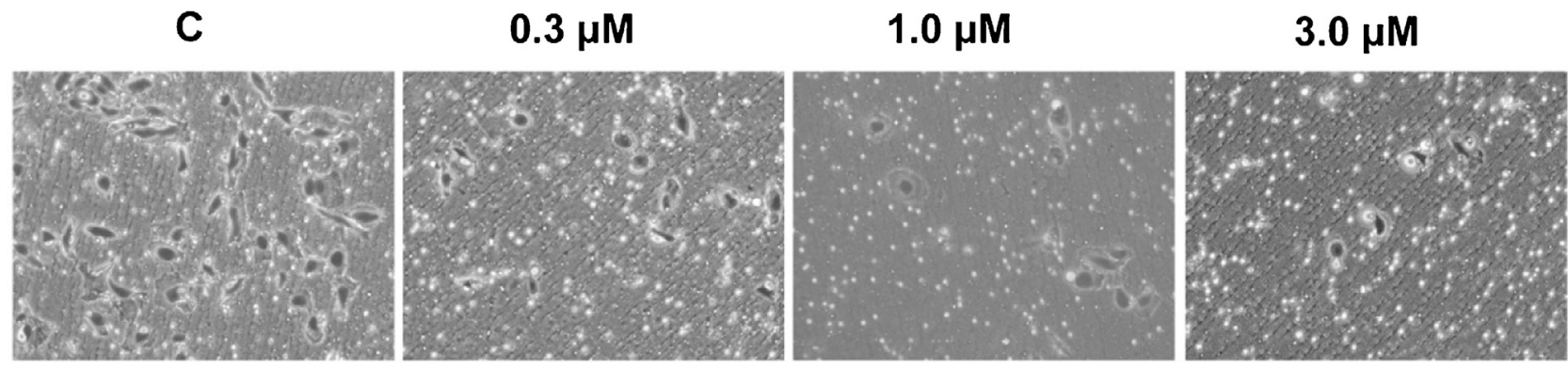

Fig. 9. D-SET inhibits the cell-invasion capacity of HeLa cells through Matrigel-coated Boyden chambers. (A) Statistical analysis of the percentage of invasive cells after incubation for $24 \mathrm{~h}$ with the test compound. (B) Images from a visual field of one representative experiment. Results are mean values \pm SEM of the data on three separate measurements with duplicates. ${ }^{* *}$ indicates $\mathrm{p}<0.01,{ }^{* * *}$ indicates $\mathrm{p}<0.001$ as compared with the untreated control samples.

D-SET is able to induce apoptosis in both HeLa and C-33 A cells, but has no inhibitory effect on cell growth on SiHa cell population may lie in the different levels of apoptotic proteins, depending on the HPV status. Hougardy et al. reported that the levels of expression of the mitochondrial related proapoptotic proteins Bid and $\mathrm{Bcl}-2$ are much lower in SiHa than in HeLa and C-33 A cells. Bid is an essential factor for mitotic pathway activation and also an intermediate between the extrinsic and intrinsic apoptotic pathways [62]. Additionally, Aguilar-Lemarroy et al. reported that HPV16-carrying cells were remarkably resistant to CD95-mediated apoptosis as a result of lacking Bcl-2 expression, and that SiHa cells failed to recruit FADD and pro-caspase-8 through the death effector domain because in SiHa cells FADD is missing from the death inducing signaling complex (DISC). Therefore the inability to build up a functional DISC [63] and the lack of Bid and Bcl-2 expression may explain why SiHa cells can avoid apoptotic signals, and why they showed no changes of cell growth after D-SET treatment, while pronounced growth inhibitory and proapoptotic effect of D-SET were evident on the other two (HeLa and C-33 A) cervical cell lines.

To investigate the mechanism of antiproliferative action, the apoptosis-inducing effect of D-SET was first proven by three independent methods, including HOPI double staining, measurement of caspase- 3 activity and cell cycle analyses. Morphological changes detected after incubation for $24 \mathrm{~h}$ have confirmed the proapoptotic effect of D-SET, and a concentration-dependent increase in the number of cells with condensed DNA and Hoechst accumulation have been observed in both HeLa and C-33 A cells. Increasing concentration leads to the presence of late apoptotic or secondary necrotic cells, showing a loss of membrane function visualized by PI. Caspase- 3 is a critical executive enzyme of the apoptotic process, and therefore after the morphological evidence, enhanced caspase- 3 activation have been observed in HeLa cells after a 14 h-treatment with D-SET, indicating that D-SET is able to provoke apoptotic enzyme production besides the chromatin changes. Furthermore, after incubation with 1.0 $\mu \mathrm{M}$ and 3.0 $\mu \mathrm{M} \mathrm{D}-$ SET for $24 \mathrm{~h}$, progressive DNA content elimination has been observed both in HeLa and C-33 A cells as demonstrated by flow cytometric analyses. This elimination is related to the apoptotic process occurring as an increased ratio of the subG1 population [44]. All of these results suggest that D-SET possesses a potent proapoptotic activity, resulting in apoptotic attributes, such as specific morphological changes and DNA fragmentation seen on HeLa and C-33 A cells, as well as caspase activation, demonstrated on HeLa cells.

Cell cycle analyses also provided some important details about the mechanism of action of D-SET. After incubation for $24 \mathrm{~h}$ both of the sensitive cell lines (HeLa and C-33 A) showed a significant elevation of cell number in the G2/M phase, indicating a cell cycle blockade at G2/M. These results are similar to those previously reported on other steroid analogs such as the natural steroid alkaloid solanidine, the natural estrogen metabolite 2-ME or the 
synthetic D-homoestrone [12,55,57]. For a precise distinction between the G2 and M phases, phosphorylated histone-H3 (Ser10) was measured after D-SET treatment. During the $M$ phase, chromatin condensation is one of the most important steps in the preparation for cell division, and the phosphorylation of $\mathrm{H} 3$ is constitutively activated in the metaphase, while at the end of the mitosis a rapid dephosphorylation of $\mathrm{H} 3$ occurs [46]. While the previously mentioned steroid analogs can all cause G2/M phase arrest, their detailed mechanisms are different. However, it has been reported that D-homoestrone can trigger G2 phase blockade with a checkpoint failure, 2-ME is related with abnormal spindle formation during the M-phase [14,60]. In our study, D-SET treatment was found to significantly increase the proportion of phosphorylated histone $\mathrm{H} 3$ protein, leading to the conclusion that, it provokes a cell cycle blockade at the M-phase, similarly to the Aring substituted metabolite 2-ME.

Tubulin polymerization is an important and crucial process during the mitosis. While 2-ME has been reported to inhibit the polymerization through the colchicine-binding site of tubulin, in contrast, some secoestrogens are able to enhance the formation of microtubuli from tubulin dimers $[20,64]$. Correspondingly, we investigated the direct effect of D-SET on tubulin polymerization in vitro in a cell-independent system. D-SET significantly increased the maximum rate of microtubule formation, and enhanced tubulin polymerization as well as the overall polymer mass of the reaction, just like the above-mentioned secoestrogens. As the imbalance between polymerization and depolymerization of microtubuli leads to the termination of cell division [65], this shift in either direction is utilized in tumor therapy (agents with these mechanism of action include the depolymerizing agent nocodasole or the tubulin-polymerizing agent paclitaxel). D-SET shifts the dynamic equilibrium between tubulin dimers and microtubule formation towards microtubule assembly and stabilization, resulting in an aberrant mitosis. As a consequence, cells cannot progress the cell cycle progression and accumulate at the M-phase; triggering an apoptotic cell death. Invasive growth and metastasis formation are the main manifestations of tumor progression, where cell invasion is a key factor for further cancer progression and the appearance of distant metastasis. The dissemination of cancer cells from the primary tumor to a distant organ can lead to severe organ failure and the patient's death $[33,66,67]$. Our findings reveal that, beside its antiproliferative, proapoptotic and tubulin inhibiting activies, D-SET also has a potent anti-migratory capacity after incubation for $24 \mathrm{~h}$, resulting from its significant inhibitory effects on cell migration and invasion. We have also demonstrated that the inhibition of cell motility becomes obvious at a concentration of $0.1 \mu \mathrm{M}$, which is below the antiproliferative concentration, and reaches its maximum near the $\mathrm{IC}_{50}$ value. Cell migration and invasion are two of the initial steps of metastasis formation and our finding suggest that D-SET can be a potent antimetastatic agent due to its migration and invasion inhibiting effect. The previously mentioned A-ring derivatives are reported to have potent anti-metastatic effects [38-40], but no literature data are available on D-ring modified analogs or on secoestrogens. Our study revealed that similarly to 2ME, D-SET also able to inhibit cancer cell motility, suggesting that D-ring analogs may have an antimetastatic effect similarly that Aring derivatives. All of these findings establish the detailed investigations into the changes of the metastatic cascade after D-SET exposure, including studies of its anti-angiogenic or cell adhesion inhibitory properties.

Our study is the first one to demonstrate the mechanism of action of secoestrogens on tumor cells, clarifying our understanding on how secoestrogens influence cell cycle, apoptosis and motility of cancer cells.
In conclusion, our results have demonstrated that the D-SET is a potent antiproliferative agent, which causes $M$ phase blockade during the cell cycle by stabilizing tubulin polymers, leading to programmed cell death. Besides its pro-apoptotic effect D-SET is suggest to show antimetastatic potential in the investigated cervical cancer cell lines. Based on the presented findings, D-SET can be regarded as a new drug candidate with a promising new mechanism of action among the antiproliferative steroids, and may potentially allow the design of novel anticancer agents.

\section{Acknowledgments}

The authors are grateful for financial support from the Hungarian Scientific Research Fund (OTKA K113150 and K109293). The work of Noémi Bózsity and Renáta Minorics was supported by a PhD Fellowship of the Talentum Fund of Richter Gedeon Plc. (Budapest) and a János Bolyai Research Scholarship of the Hungarian Academy of Sciences, respectively. The project "TÁMOP-4.2.1/B-09/1/KONV-2010-0005-Creating the Center of Excellence at the University of Szeged" is supported by the European Union and co-financed by the European Social Fund.

\section{Appendix A. Supplementary data}

Supplementary data associated with this article can be found, in the online version, at http://dx.doi.org/10.1016/j. jsbmb.2016.06.013.

\section{References}

[1] L.A. Torre, F. Bray, R.L. Siegel, J. Ferlay, J. Lortet-Tieulent, A. Jemal, Global cancer statistics, 2012, CA Cancer J. Clin. 65 (2) (2015) 87-108.

[2] J. Ferlay, E. Steliarova-Foucher, J. Lortet-Tieulent, S. Rosso, J.W. Coebergh, H. Comber, D. Forman, F. Bray, Cancer incidence and mortality patterns in Europe: estimates for 40 countries in 2012, Eur. J. Cancer 49 (6) (2013) 1374-1403.

[3] R. Ghittoni, R. Accardi, S. Chiocca, M. Tommasino, Role of human papillomaviruses in carcinogenesis, Ecancermedicalscience 9 (2015) 526.

[4] A. Goodman, HPV testing as a screen for cervical cancer, BMJ 350 (2015) h2372.

[5] F. Chidyaonga-Maseko, M.L. Chirwa, A.S. Muula, Underutilization of cervical cancer prevention services in low and middle income countries: a review of contributing factors, Pan Afr. Med. J. 21 (2015) 231.

[6] K. Valentino, C.B. Poronsky, Human papillomavirus infection and vaccination, J. Pediatr. Nurs. 31 (2) (2016) e155-e166.

[7] S. Kumar, M. Biswas, T. Jose, HPV vaccine: current status and future directions, Med. J. Armed Forces India 71 (2) (2015) 171-177.

[8] S.S. Smith, Female sex steroid hormones: from receptors to networks to performance-actions on the sensorimotor system, Prog. Neurobiol. 44 (1) (1994) 55-86.

[9] R.B. Dickson, G.M. Stancel, Estrogen receptor-mediated processes in normal and cancer cells, J. Natl. Cancer Inst. Monogr. 27 (2000) 135-145.

[10] A.O. Mueck, H. Seeger, 2-Methoxyestradiol-biology and mechanism of action, Steroids 75 (10) (2010) 625-631.

[11] G. Schumacher, P. Neuhaus, The physiological estrogen metabolite 2methoxyestradiol reduces tumor growth and induces apoptosis in human solid tumors, J. Cancer Res. Clin. Oncol. 127 (7) (2001) 405-410.

[12] L. Li, S. Bu, T. Backstrom, M. Landstrom, U. Ulmsten, X. Fu, Induction of apoptosis and G2/M arrest by 2-methoxyestradiol in human cervical cancer HeLaS3 cells, Anticancer Res. 24 (2b) (2004) 873-880.

[13] L. Li, N.E. Heldin, J. Grawe, U. Ulmsten, X. Fu, Induction of apoptosis or necrosis in human endometrial carcinoma cells by 2 -methoxyestradiol, Anticancer Res. 24 (6) (2004) 3983-3990

[14] H.J. Choi, B.T. Zhu, Critical role of cyclin B1/Cdc2 up-regulation in the induction of mitotic prometaphase arrest in human breast cancer cells treated with 2 methoxyestradiol, Biochim. Biophys. Acta 1823 (8) (2012) 1306-1315.

[15] B.A. Stander, S. Marais, C.J. Vorster, A.M. Joubert, In vitro effects of 2methoxyestradiol on morphology, cell cycle progression, cell death and gene expression changes in the tumorigenic MCF-7 breast epithelial cell line, J. Steroid Biochem. Mol. Biol. 119 (3-5) (2010) 149-160.

[16] S.L. Mooberry, Mechanism of action of 2-methoxyestradiol: new developments, Drug Resist. Update 6 (6) (2003) 355-361.

[17] J.A. Petrovic, V.M. Pejanovic, D.A. Miljkovic, J.T. Hranisavljevic, Synthesis and estrogen activity screening of some new D-secoestrone derivatives, Steroids 55 (6) (1990) 276-278. 
[18] S.S. Jovanovic-Santa, E.T. Petri, O.R. Klisuric, M. Szecsi, R. Kovacevic, J.A. Petrovic, Antihormonal potential of selected D-homo and D-seco estratriene derivatives, Steroids 97 (2015) 45-53.

[19] S. Jovanovic-Santa, J. Petrovic, S. Andric, R. Kovacevic, E. Durendic, M. Sakac, D. Lazar, S. Stankovic, Synthesis, structure, and screening of estrogenic and antiestrogenic activity of new 3,17-substituted-16,17-seco-estratriene derivatives, Bioorg. Chem. 31 (6) (2003) 475-484.

[20] E. Mernyak, J. Szabo, I. Bacsa, J. Huber, G. Schneider, R. Minorics, N. Bozsity, I. Zupko, M. Varga, Z. Bikadi, E. Hazai, J. Wolfling, Syntheses and antiproliferative effects of D-homo- and D-secoestrones, Steroids 87 (2014) 128-136.

[21] M. Ruzzene, D. Penzo, L.A. Pinna, Protein kinase CK2 inhibitor 4,5,6,7tetrabromobenzotriazole (TBB) induces apoptosis and caspase-dependent degradation of haematopoietic lineage cell-specific protein 1 (HS1) in Jurkat cells, Biochem. J. 364 (Pt 1) (2002) 41-47.

[22] A.S. Gundugola, K.L. Chandra, E.M. Perchellet, A.M. Waters, J.P. Perchellet, S. Rayat, Synthesis and antiproliferative evaluation of 5-oxo and 5-thio derivatives of 14 -diaryl tetrazoles, Bioorg. Med. Chem. Lett. 20 (13) (2010) 3920-3924.

[23] J. Fu, Y. Yang, X.W. Zhang, W.J. Mao, Z.M. Zhang, H.L. Zhu, Discovery of $1 \mathrm{H}-$ benzo[d][12,3]triazol-1-yl 3,4,5-trimethoxybenzoate as a potential antiproliferative agent by inhibiting histone deacetylase, Bioorg. Med. Chem. 18 (24) (2010) 8457-8462.

[24] B.A. Bhat, P.B. Reddy, S.K. Agrawal, A.K. Saxena, H.M. Kumar, G.N. Qazi, Studies on novel 4b-[(4-substituted)-1,2,3-triazol-1-yl] podophyllotoxins as potential anticancer agents, Eur. J. Med. Chem. 43 (10) (2008) 2067-2072.

[25] V.D. Handratta, D. Jelovac, B.J. Long, R. Kataria, I.P. Nnane, V.C. Njar, A.M. Brodie Potent CYP17 inhibitors: improved syntheses, pharmacokinetics and antitumor activity in the LNCaP human prostate cancer model, J. Steroid Biochem. Mol. Biol. 92 (3) (2004) 155-165.

[26] A.H. Banday, S.A. Shameem, B.D. Gupta, H.M. Kumar, D-ring substituted 12,3 triazolyl 20-keto pregnenanes as potential anticancer agents: synthesis and biological evaluation, Steroids 75 (12) (2010) 801-804.

[27] E. Frank, J. Molnár, I. Zupkó, Z. Kádár, J. Wölfling, Synthesis of novel steroidal $17 \alpha$-triazolyl derivatives via $\mathrm{Cu}(\mathrm{I})$-catalyzed azide-alkyne cycloaddition, and an evaluation of their cytotoxic activity in vitro, Steroids 76 (10-11) (2011) $1141-1148$.

[28] Z. Kádár, D. Kovács, E. Frank, G. Schneider, J. Huber, I. Zupkó, T. Bartók, J. Wölfling, Synthesis and in vitro antiproliferative activity of novel androst-5ene triazolyl and tetrazolyl derivatives, Molecules 16 (6) (2011) 4786-4806.

[29] J. Molnár, E. Frank, R. Minorics, Z. Kádár, I. Ocsovszki, B. Schonecker, J. Wölfling, I. Zupkó, A click approach to novel D-ring-substituted $16 \alpha$-triazolylestrone derivatives and characterization of their antiproliferative properties, PLoS One 10 (2) (2015) e0118104.

[30] L. Liang, D. Astruc, The copper(I)-catalyzed alkyne-azide cycloaddition (CuAAC) click reaction and its applications. An overview, Coord. Chem. Rev. $255(23-24)(2011)$ 2933-2945.

[31] E. Mernyák, G. Fiser, J. Szabó, B. Bodnár, G. Schneider, I. Kovács, I. Ocsovszki, I. Zupkó, J. Wölfling, Synthesis and in vitro antiproliferative evaluation of dsecooxime derivatives of $13 \mathrm{~b}$ - and $13 \alpha$-estrone, Steroids 89 (2014) 47-55.

[32] J. Szabó, N. Jerkovics, G. Schneider, J. Wölfling, N. Bózsity, R. Minorics, I. Zupkó, E. Mernyák, Synthesis and in vitro antiproliferative evaluation of C-13 epimers of triazolyl-D-secoestrone alcohols: the first potent $13 \alpha$-D-secoestrone derivative, Molecules 21 (5) (2016) 611.

[33] H. Yamaguchi, J. Wyckoff, J. Condeelis, Cell migration in tumors, Curr. Opin. Cell Biol. 17 (5) (2005) 559-564.

[34] W.J. Polacheck, I.K. Zervantonakis, R.D. Kamm, Tumor cell migration in complex microenvironments, Cell. Mol. Life Sci. 70 (8) (2013) 1335-1356.

[35] Y. Huang, J. Li, L. Xiang, D. Han, X. Shen, X. Wu, 17beta-Oestradiol activates proteolysis and increases invasion through phosphatidylinositol 3-kinase pathway in human cervical cancer cells, Eur. J. Obstet. Gynecol. Reprod. Biol. 165 (2) (2012) 307-312.

[36] R.X. Guo, L.H. Wei, Z. Tu, P.M. Sun, J.L. Wang, D. Zhao, X.P. Li, J.M. Tang, 17 betaestradiol activates PI3K/Akt signaling pathway by estrogen receptor (ER)dependent and ER-independent mechanisms in endometrial cancer cells, J. Steroid Biochem. Mol. Biol. 99 (1) (2006) 9-18.

[37] K. Hua, W. Feng, Q. Cao, X. Zhou, X. Lu, Y. Feng, Estrogen and progestin regulate metastasis through the PI3K/AKT pathway in human ovarian cancer, Int. J. Oncol. 33 (5) (2008) 959-967.

[38] H.L. Lin, M.H. Yang, C.W. Wu, P.M. Chen, Y.P. Yang, Y.R. Chu, C.L. Kao, H.H. Ku, J.F. Lo, J.P. Liou, C.W. Chi, S.H. Chiou, 2-Methoxyestradiol attenuates phosphatidylinositol 3-kinase/Akt pathway-mediated metastasis of gastric cancer, Int. J. Cancer 121 (11) (2007) 2547-2555.

[39] M. Sattler, L.R. Quinnan, Y.B. Pride, J.L. Gramlich, S.C. Chu, G.C. Even, S.K. Kraeft, L.B. Chen, R. Salgia, 2-Methoxyestradiol alters cell motility, migration, and adhesion, Blood 102 (1) (2003) 289-296.

[40] B.A. Stander, F. Joubert, C. Tu, K.H. Sippel, R. McKenna, A.M. Joubert, In vitro evaluation of ESE-15-ol, an estradiol analogue with nanomolar antimitotic and carbonic anhydrase inhibitory activity, PLoS One 7 (12) (2012) e52205.

[41] C. Yee, I. Krishnan-Hewlett, C.C. Baker, R. Schlegel, P.M. Howley, Presence and expression of human papillomavirus sequences in human cervical carcinoma cell lines, Am. J. Pathol. 119 (3) (1985) 361-366.
[42] T. Mosmann, Rapid colorimetric assay for cellular growth and survival: application to proliferation and cytotoxicity assays, J. Immunol. Methods 65 (1-2) (1983) 55-63.

[43] M. Fritzer-Szekeres, I. Savinc, Z Horvath, P. Saiko, M. Pemberger, G Graser, A Bernhaus, M. Ozsvar-Kozma, M. Grusch, W. Jaeger, T. Szekeres, Biochemical effects of piceatannol in human HL-60 promyelocytic leukemia cellssynergism with Ara-C, Int. J. Oncol. 33 (4) (2008) 887-892.

[44] I. Vermes, C. Haanen, C. Reutelingsperger, Flow cytometry of apoptotic cell death, J. Immunol. Methods 243 (1-2) (2000) 167-190.

[45] M.A. Jordan, K. Wendell, S. Gardiner, W.B. Derry, H. Copp, L. Wilson, Mitotic block induced in HeLa cells by low concentrations of paclitaxel (Taxol) results in abnormal mitotic exit and apoptotic cell death, Cancer Res. 56 (4) (1996) 816-825.

[46] G. Juan, F. Traganos, W.M. James, J.M. Ray, M. Roberge, D.M. Sauve, H. Anderson, Z. Darzynkiewicz, Histone H3 phosphorylation and expression of cyclins A and B1 measured in individual cells during their progression through G2 and mitosis, Cytometry 32 (2) (1998) 71-77.

[47] J. Behrens, P. Kameritsch, S. Wallner, U. Pohl, K. Pogoda, The carboxyl tail of Cx43 augments p38 mediated cell migration in a gap junction-independent manner, Eur. J. Cell Biol. 89 (11) (2010) 828-838.

[48] R. Kaur, G. Kaur, R.K. Gill, R. Soni, J. Bariwal, Recent developments in tubulin polymerization inhibitors: an overview, Eur. J. Med. Chem. 87 (2014) 89-124.

[49] W. Zhang, X. Men, P. Lei, Review on anti-tumor effect of triterpene acid compounds, J. Cancer Res. Ther. 10 (Suppl. 1) (2014) 14-19.

[50] H. Sun, C. Lv, L. Yang, Y. Wang, Q. Zhang, S. Yu, H. Kong, M. Wang, J. Xie, C. Zhang, M. Zhou, Solanine induces mitochondria-mediated apoptosis in human pancreatic cancer cells, Biomed. Res. Int. 2014 (2014) 805926.

[51] R. Minorics, T. Szekeres, G. Krupitza, P. Saiko, B. Giessrigl, J. Wolfling, E. Frank, I. Zupko, Antiproliferative effects of some novel synthetic solanidine analogs on HL-60 human leukemia cells in vitro, Steroids 76 (1-2) (2011) 156-162.

[52] S.N. Sunassee, T. Ransom, C.J. Henrich, J.A. Beutler, D.G. Covell, J.B. McMahon, K. R. Gustafson, Steroidal alkaloids from the marine sponge Corticium niger that inhibit growth of human colon carcinoma cells, J. Nat. Prod. 77 (11) (2014) 2475-2480.

[53] M. Nesher, U. Shpolansky, H. Rosen, D. Lichtstein, The digitalis-like steroid hormones: new mechanisms of action and biological significance, Life Sci. 80 (23) (2007) 2093-2107.

[54] M.I. Khan, J.A. Chesney, D.A. Laber, D.M. Miller, Digitalis, a targeted therapy for cancer? Am. J. Med. Sci. 337 (5) (2009) 355-359.

[55] M. Slingerland, C. Cerella, H.J. Guchelaar, M. Diederich, H. Gelderblom, Cardiac glycosides in cancer therapy: from preclinical investigations towards clinical trials, Invest. New Drugs 31 (4) (2013) 1087-1094.

[56] L. MacCarthy-Morrogh, P.A. Townsend, A. Purohit, H.A.M. Hejaz, B.V.L. Potter, M.J. Reed, G. Packham, Differential effects of estrone and estrone-3-Osulfamate derivatives on mitotic. Arrest, apoptosis, and microtubule assembly in human breast cancer cells, Cancer Res. 60 (19) (2000) 5441-5450.

[57] R. Minorics, N. Bozsity, J. Wolfling, E. Mernyak, G. Schneider, A. Marki, G. Falkay, I. Ocsovszki, I. Zupko, Antiproliferative effect of normal and 13-epi-Dhomoestrone and their 3-methyl ethers on human reproductive cancer cell lines, J. Steroid Biochem. Mol. Biol. 132 (1-2) (2012) 168-175.

[58] G.M. Anstead, K.E. Carlson, J.A. Katzenellenbogen, The estradio pharmacophore: ligand structure-estrogen receptor binding affinity relationships and a model for the receptor binding site, Steroids 62 (3) (1997) 268-303.

[59] S.S. Jovanović-Šanta, S. Andrić, N. Andrić, G. Bogdanović, J.A. Petrović, Evaluation of biological activity of new hemiesters of 17-hydroxy-16,17secoestra-1,3,5(10)-triene-16-nitrile, Med. Chem. Res. 20 (7) (2010) 1102-1110.

[60] R. Minorics, N. Bozsity, J. Molnar, J. Wolfling, E. Mernyak, G. Schneider, I. Ocsovszki, I. Zupko, A molecular understanding of d-homoestrone-induced G2/M cell cycle arrest in HeLa human cervical carcinoma cells, J. Cell Mol. Med. 19 (10) (2015) 2365-2374

[61] P. Mallmann, M.W. Beckmann, G. Emons, Innovations in cervical and endometrial cancer, Geburtshilfe Frauenheilkd 73 (9) (2013) 908-910.

[62] B.M. Hougardy, A.G. van der Zee, F.A. van den Heuvel, T. Timmer, E.G. de Vries, S. de Jong, Sensitivity to Fas-mediated apoptosis in high-risk HPV-positive human cervical cancer cells: relationship with Fas, caspase-8, and Bid, Gynecol. Oncol. 97 (2) (2005) 353-364.

[63] A. Aguilar-Lemarroy, S. Kirchhoff, N. Whitaker, P. Gariglio, H. zur Hausen, P.H. Krammer, F. Rosl, Differential sensitivity of human papillomavirus type 16(+) and type $18(+)$ cervical carcinoma cells to CD95-mediated apoptosis, Int. J. Cancer 93 (6) (2001) 823-831.

[64] J.F. Peyrat, J.D. Brion, M. Alami, Synthetic 2-methoxyestradiol derivatives: structure-activity relationships, Curr. Med. Chem. 19 (24) (2012) 4142-4156.

[65] K.N. Bhalla, Microtubule-targeted anticancer agents and apoptosis, Oncogene 22 (56) (2003) 9075-9086.

[66] N.V. Krakhmal, M.V. Zavyalova, E.V. Denisov, S.V. Vtorushin, V.M. Perelmuter, Cancer invasion: patterns and mechanisms, Acta Naturae 7 (2) (2015) 17-28.

[67] C.D. Simpson, K. Anyiwe, A.D. Schimmer, Anoikis resistance and tumor metastasis, Cancer Lett. 272 (2) (2008) 177-185. 
II. 
Article

\title{
Synthesis and in Vitro Antiproliferative Evaluation of C-13 Epimers of Triazolyl-D-Secoestrone Alcohols: The First Potent 13 $\alpha$-D-Secoestrone Derivative
}

\author{
Johanna Szabó ${ }^{1}$, Nóra Jerkovics ${ }^{1}$, Gyula Schneider ${ }^{1}$, János Wölfling ${ }^{1}$, Noémi Bózsity ${ }^{2}$, \\ Renáta Minorics ${ }^{2}$, István Zupkó ${ }^{2}$ and Erzsébet Mernyák ${ }^{1, *}$ \\ 1 Department of Organic Chemistry, University of Szeged, Dóm tér 8, Szeged H-6720, Hungary; \\ johanna.szab@gmail.com (J.S.); jerkovicsnora@gmail.com (N.J.); schneider@chem.u-szeged.hu (G.S.); \\ wolfling@chem.u-szeged.hu (J.W.) \\ 2 Department of Pharmacodynamics and Biopharmacy, University of Szeged, Eötvös u. 6, Szeged H-6720, \\ Hungary; bozsity.noemi@pharm.u-szeged.hu (N.B.); minorics@pharm.u-szeged.hu (R.M.); \\ zupko@pharm.u-szeged.hu (I.Z.) \\ * Correspondence: bobe@chem.u-szeged.hu; Tel.: +36-62-544-277
}

Academic Editor: Maria Emília de Sousa

Received: 31 March 2016; Accepted: 29 April 2016; Published: 12 May 2016

\begin{abstract}
The syntheses of C-13 epimeric 3-[(1-benzyl-1,2,3-triazol-4-yl)methoxy]-D-secoestrones are reported. Triazoles were prepared from 3-(prop-2-inyloxy)-D-secoalcohols and $p$-substituted benzyl azides via $\mathrm{Cu}(\mathrm{I})$-catalyzed azide-alkyne cycloaddition (CuAAC). The antiproliferative activities of the products and their precursors were determined in vitro against a panel of human adherent cervical (HeLa, SiHa and C33A), breast (MCF-7, MDA-MB-231, MDA-MB-361 and T47D) and ovarian (A2780) cell lines by means of MTT assays. The orientation of the angular methyl group and the substitution pattern of the benzyl group of the azide greatly influenced the cell growth-inhibitory potential of the compounds. The $13 \beta$ derivatives generally proved to be more potent than their $13 \alpha$ counterparts. Introduction of a benzyltriazolylmethyl group onto the $3-\mathrm{OH}$ position seemed to be advantageous. One $13 \alpha$ compound containing an unsubstituted benzyltriazolyl function displayed outstanding antiproliferative activities against three cell lines.
\end{abstract}

Keywords: antiproliferative effect; azide-alkyne cycloaddition; D-secoestrone; triazole

\section{Introduction}

Anticancer drug design based on synthetic modifications of naturally occurring biomolecules may lead to nontoxic drug candidates with selective antitumoral potencies [1,2]. Estrone-based anticancer agents are already utilized in therapy, but one of the most important requirements of these drugs is a lack of original hormonal activity $[3,4]$. The literature provides evidence that inversion of the configuration at $\mathrm{C}-13$ or the opening of ring $\mathrm{D}$ of the estrane core may lead to the loss of estrogenic activity [5-9]. We recently reported that 3-benzyl ethers of D-secoestrone alcohol or oxime (compounds 1 and 2, Figure 1.) exert substantial in vitro cell growth-inhibitory action against a number of cancer cell lines, with $\mathrm{IC}_{50}$ values in the low micromolar or submicromolar range $[10,11]$. Compounds $\mathbf{1}$ and $\mathbf{2}$ were diversified at several sites in the molecule, including different modifications (etherifications, esterifications or debenzylations) at C-3 and / or C-17 and epimerization at C-13 (only in the case of 2). It was concluded that the nature of the 3- and 17-functional groups exerts a great impact on the antiproliferative behavior of the compounds. 3-Ethers proved to be more potent than their $3-\mathrm{OH}$ counterparts. Derivatives containing a 17-oxime function displayed more pronounced cytostatic properties than those of 17-hydroxymethyl derivatives. 3-Hydroxy-D-secooxime 2, but not the D-secoalcohol 1, was further derivatized by introducing a terminal alkyne function onto the 3-OH 
group by using propargyl bromide, and the resulting steroid alkyne was subjected to $\mathrm{Cu}(\mathrm{I})$-catalyzed azide-alkyne cycloaddition (CuAAC) with different substituted benzyl azides. The triazole moiety is frequently used as a linker in bioconjugates, because it is a good mimic of peptide bonding with high proteolytic and metabolic stability [12-14]. Introduction of a triazolyl function into the oxime 2 led to improved antiproliferative properties as compared with the 3-benzyl ether. The benzyltriazolylmethoxy D-secooxime 3 (Figure 1) exerted substantial cell growth-inhibitory effects against several human cancer cell lines.
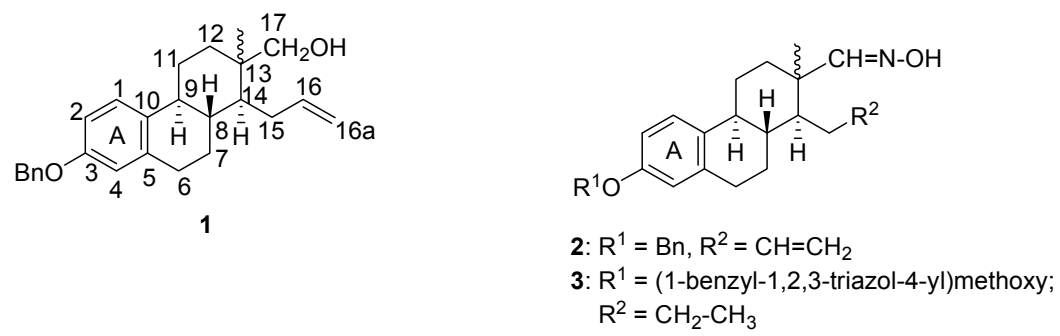

Figure 1. Structures of the potent antiproliferative D-secoestrones $\mathbf{1}$ and 2, 3 .

The abovementioned outstanding results suggested that it might be useful to introduce the benzyltriazolyl function onto other positions of the D-secoestrone scaffold. In a continuation of our earlier work, we focused herein on the synthesis of steroidal alkynes bearing a terminal alkyne function on the opened ring D. The D-secoestrone 17-carboxylic acids were reacted with propargylamine using peptide coupling reagents [15]. The reactions were carried out in both the $13 \alpha-$ and the $13 \beta$-estrone series in order to obtain more compounds for structure-activity determinations. The resulting $N$-propargyl 17-carboxamides were reacted with small molecule azides, such as substituted benzyl azides, and the resulting triazoles were evaluated for their antiproliferative activities against several human reproductive cancer cell lines. The activities of the compounds depended greatly on the substitution pattern of the aromatic ring of the benzyl azide moiety. 3-Benzyl ethers of $13 \beta$-( $p$-alkylbenzyl)triazoles displayed outstanding selective antiproliferative potential against A2780 cells.

There are already a number of literature examples of the synthesis of antiproliferative steroidal triazoles formed mainly from steroid azides and small molecule alkynes, such as phenylacetylenes. It has been found that the cytostatic activity of the resulting triazoles depends considerably on the substitution pattern of the phenyl group of the acetylene [16-22].

In view of the abovementioned recent results, we aimed to introduce the benzyltriazolylmethoxy moiety onto the 3-OH group of the C-13 epimeric D-secoalcohols. The synthesis of the D-secoestrone alkynes were first planned at position C-3, followed by the $\mathrm{CuAAC}$ reactions of the secosteroidal alkynes with substituted benzyl azides. The next goal was to perform comparative investigations of the in vitro antiproliferative activities of the products and their precursors by means of MTT assays against a panel of human adherent cervical (HeLa, SiHa and C33A), breast (MCF-7, MDA-MB-231, MDA-MB-361 and T47D) and ovarian (A2780) cell lines. Our main objective was to establish some structure-activity relationship, focusing particularly on the C-13 epimeric character of the compounds.

\section{Results}

We first synthesized steroidal alkynes in both the $13 \alpha$ - and the $13 \beta$-D-secoestrone series (Scheme 1). After removal of the benzyl protecting group of compounds $\mathbf{1}$ or $\mathbf{6}$ by hydrogenolysis, an excess of propargyl bromide was added in the presence of $\mathrm{K}_{2} \mathrm{CO}_{3}$, leading to the 3-(prop-2-inyloxy)-17-alcohols $\mathbf{9}$ or $\mathbf{1 0}$. The terminal alkynes 9 or $\mathbf{1 0}$ were reacted with benzyl azide (11a) or its substituted derivatives 11b-e under recently published CuAAC reaction conditions [20], furnishing the desired triazolyl compounds 12a-e or 13a-e in high yields. The structures of the triazoles were established from the corresponding ${ }^{1} \mathrm{H}$ - and ${ }^{13} \mathrm{C}-\mathrm{NMR}$ spectra. 


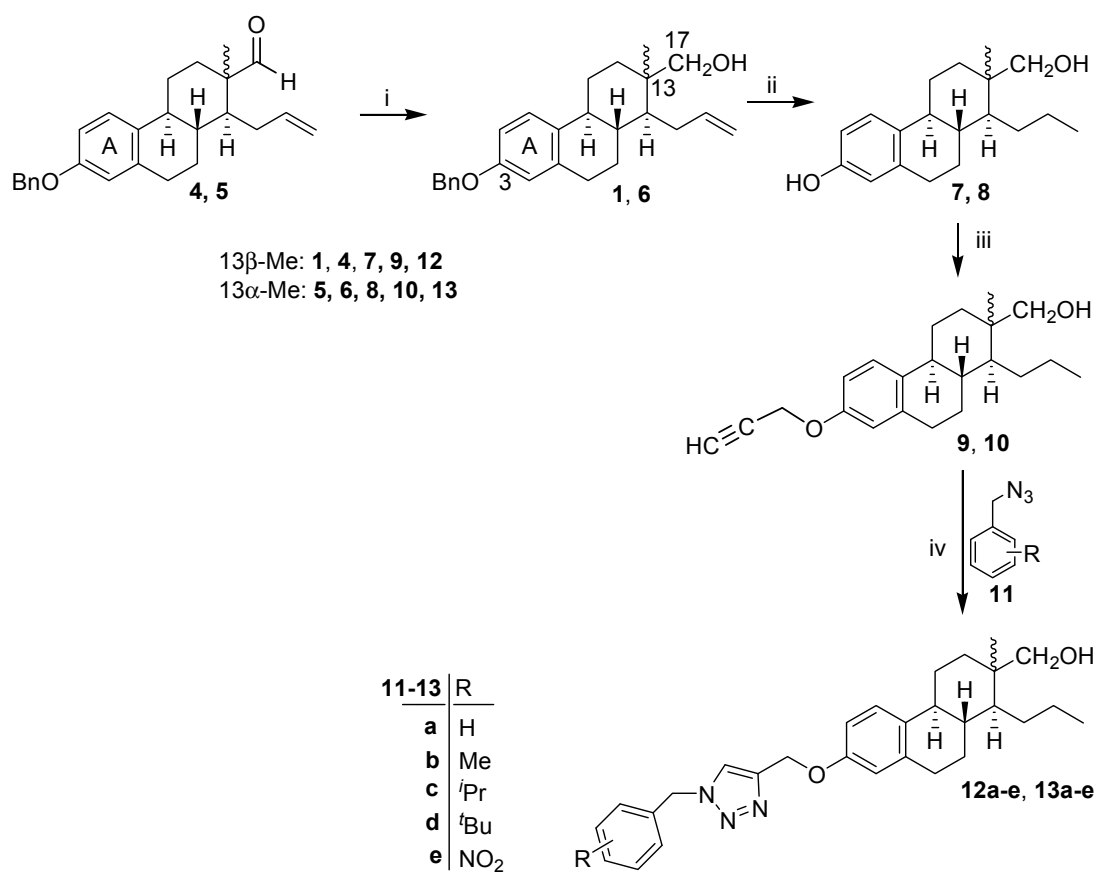

Scheme 1. Synthesis of D-secoestrone derivatives (12a-e and 13a-e). Reagents and conditions: (i) 5 equiv. $\mathrm{KBH}_{4}, \mathrm{CH}_{2} \mathrm{Cl}_{2}: \mathrm{MeOH}=1: 1,0{ }^{\circ} \mathrm{C}$-r.t., 0.5 h; (ii) $\mathrm{H}_{2}$ (20 bar), Pd/C, EtOAc, 3 h; (iii) propargyl bromide (1.5 equiv.), $\mathrm{K}_{2} \mathrm{CO}_{3}$ (7 equiv.), acetone, $70{ }^{\circ} \mathrm{C}, 24 \mathrm{~h}$; (iv) $\mathrm{CuI}$ (0.05 equiv.), $\mathrm{Ph}_{3} \mathrm{P}$ (0.1 equiv.), DIPEA (3 equiv.), toluene, reflux, $2 \mathrm{~h}$.

The cell growth-inhibitory activities of the triazoles and their precursors were determined in vitro against a panel of human adherent cervical (HeLa, SiHa and C33A), breast (MCF-7, MDA-MB-231, MDA-MB-361 and T47D) and ovarian (A2780) cell lines by means of MTT assays (Table 1). The 3-benzyl ether of the 13 $\beta$-D-secoalcohol 1 selectively inhibited the growth of MCF-7 cells, with inhibition values $>80 \%$ at $10 \mu \mathrm{M}$. Its C-13 epimer 6 at $10 \mu \mathrm{M}$ displayed $<50 \%$ inhibition on all the examined cell lines. The 3-OH derivatives 7 and $\mathbf{8}$ exerted low antiproliferative potentials at both concentrations (even at $30 \mu \mathrm{M}$ ). Among the propargyl derivatives 9 and 10, only the $13 \beta$ epimer 9 inhibited the growth of nearly all the cell lines by $>50 \%$ at $30 \mu \mathrm{M}$. As concerns the triazoles, 12a displayed the highest antiproliferative activity against A2780, HeLa and C33A, with inhibition values $>80 \%$ at $10 \mu \mathrm{M}$. The $p$-methyl derivative $\mathbf{1 2} \mathbf{b}$ displayed somewhat lower potential against the abovementioned cell lines. Compounds 12c and 12d inhibited the growth of only two cell lines (A2780 and C33A) by $>80 \%$ at $30 \mu \mathrm{M}$. The $13 \alpha$-epimeric triazole 13a displayed substantial antiproliferative potential against A2780, Hela and C33A. 13b inhibited the growth of nearly all cell lines by $>50 \%$ at $30 \mu \mathrm{M}$. The other $13 \alpha$-epimeric triazoles $13 \mathbf{c}-\mathbf{e}$ did not influence the growth of the cell lines effectively.

Compound 12a displayed limited growth inhibition against noncancerous human fibroblast cell line (MRC-5) with values $<30 \%$ even at $30 \mu \mathrm{M}$.

\section{Discussion}

The benzyl protecting groups of the D-secoalcohols 1, 6 in both the $13 \alpha$-and the $13 \beta$-D-secoestrone series were removed by hydrogenolysis, using $\mathrm{Pd} / \mathrm{C}$ as a catalyst. The saturation of the $\delta$-alkenyl side-chain occurred simultaneously. The resulting 3,17-diols 7 and 8 were selectively alkylated at their 3-OH functions, taking advantage of the more acidic behavior of the phenolic over the alcoholic $\mathrm{OH}$ groups. The propargylations led to the desired terminal alkynes $\mathbf{9}$ or $\mathbf{1 0}$ in high yields. The steroidal alkynes were subjected to azide-alkyne cycloadditions under the earlier published reaction conditions [20], using a catalytic amount of $\mathrm{CuI}$ and $\mathrm{PPh}_{3}$ as an accelerating ligand. 
Table 1. Antiproliferative properties of the synthesized compounds. Mean value from two independent determinations with five parallel wells; standard deviation $<15 \%$.

\begin{tabular}{|c|c|c|c|c|c|c|c|c|c|}
\hline \multirow{2}{*}{ Comp. } & \multirow{2}{*}{ Conc. $(\mu \mathrm{M})$} & \multicolumn{8}{|c|}{ Inhibition $(\%) \pm \mathrm{SEM}\left(\text { Calculated } \mathrm{IC}_{50}\right)^{1}$} \\
\hline & & A2780 & Hela & SiHa & C33A & MCF-7 & T47D & MDA-MB-231 & MDA-MB-361 \\
\hline \multirow[b]{2}{*}{1} & 10 & $42.3 \pm 0.9$ & $31.4 \pm 1.6$ & -2 & $39.2 \pm 0.6$ & $81.3 \pm 0.7$ & $26.1 \pm 2.0$ & - & $28.2 \pm 0.4$ \\
\hline & 30 & $97.5 \pm 0.1$ & $97.9 \pm 0.3$ & $84.3 \pm 0.9$ & $86.9 \pm 0.7$ & $\begin{array}{c}97.4 \pm 0.3 \\
\quad(6.4)\end{array}$ & $87.2 \pm 0.9$ & $84.5 \pm 0.9$ & $87.6 \pm 0.4$ \\
\hline \multirow{2}{*}{6} & 10 & $43.6 \pm 2.4$ & $20.1 \pm 1.8$ & - & $40.4 \pm 2.1$ & - & - & - & - \\
\hline & 30 & $55.4 \pm 2.5$ & $60.3 \pm 1.4$ & $49.7 \pm 1.4$ & $53.8 \pm 1.1$ & $36.4 \pm 1.2$ & $59.6 \pm 0.8$ & $49.3 \pm 1.6$ & $77.2 \pm 1.3$ \\
\hline \multirow{2}{*}{7} & 10 & - & - & - & $40.5 \pm 0.8$ & $24.3 \pm 2.6$ & - & - & - \\
\hline & 30 & $35.1 \pm 0.8$ & $40.7 \pm 1.7$ & - & $42.3 \pm 1.8$ & $51.6 \pm 2.9$ & - & - & - \\
\hline \multirow{2}{*}{8} & 10 & - & $23.7 \pm 0.9$ & - & - & - & - & - & - \\
\hline & 30 & - & $64.5 \pm 1.1$ & - & - & - & $23.0 \pm 1.7$ & - & - \\
\hline \multirow{2}{*}{9} & 10 & $22.4 \pm 1.0$ & $21.5 \pm 0.8$ & - & $30.0 \pm 1.1$ & - & - & $36.8 \pm 2.7$ & - \\
\hline & 30 & $70.7 \pm 0.4$ & $89.3 \pm 1.9$ & $84.5 \pm 0.5$ & $70.1 \pm 0.7$ & $52.5 \pm 1.0$ & $37.7 \pm 1.3$ & $81.0 \pm 1.1$ & $59.0 \pm 2.9$ \\
\hline \multirow{2}{*}{10} & 10 & - & - & - & - & - & - & - & - \\
\hline & 30 & $29.7 \pm 1.9$ & $36.9 \pm 1.8$ & - & $39.9 \pm 1.1$ & $23.3 \pm 0.6$ & $45.5 \pm 0.6$ & $28.2 \pm 2.2$ & - \\
\hline \multirow[b]{2}{*}{$12 a$} & 10 & $81.5 \pm 1.1$ & $85.4 \pm 0.3$ & $21.2 \pm 1.1$ & $90.0 \pm 0.3$ & $66.3 \pm 0.3$ & $51.0 \pm 1.1$ & $53.5 \pm 1.2$ & $59.3 \pm 1.4$ \\
\hline & 30 & $\begin{array}{c}88.0 \pm 0.1 \\
(0.9)\end{array}$ & $\begin{array}{c}91.7 \pm 0.3 \\
(1.1)[23]\end{array}$ & $34.5 \pm 1.2$ & $\begin{array}{c}95.1 \pm 0.2 \\
(1.8)[23]\end{array}$ & $\begin{array}{c}74.5 \pm 1.7 \\
(1.5)\end{array}$ & $54.4 \pm 1.8$ & $59.6 \pm 1.8$ & $45.2 \pm 1.1$ \\
\hline \multirow[b]{2}{*}{$12 b$} & 10 & $96.8 \pm 0.2$ & $52.6 \pm 0.9$ & $48.1 \pm 0.8$ & $86.8 \pm 0.8$ & $71.6 \pm 1.0$ & $65.7 \pm 1.4$ & $58.3 \pm 0.7$ & $87.2 \pm 0.5$ \\
\hline & 30 & $\begin{array}{c}97.4 \pm 0.1 \\
(3.8)\end{array}$ & $65.4 \pm 0.9$ & $64.3 \pm 1.0$ & $\begin{array}{c}93.9 \pm 0.9 \\
(5.0)\end{array}$ & $\begin{array}{c}73.9 \pm 1.0 \\
(5.0)\end{array}$ & $66.4 \pm 1.2$ & $\begin{array}{c}86.1 \pm 0.3 \\
(8.3)\end{array}$ & $\begin{array}{c}89.3 \pm 1.1 \\
(4.4)\end{array}$ \\
\hline \multirow[b]{2}{*}{$12 c$} & 10 & $83.3 \pm 0.5$ & $27.1 \pm 1.7$ & - & $57.5 \pm 1.8$ & - & - & $33.6 \pm 0.8$ & $47.1 \pm 2.9$ \\
\hline & 30 & $\begin{array}{c}93.4 \pm 0.1 \\
(5.4)\end{array}$ & $66.0 \pm 2.4$ & $35.6 \pm 0.3$ & $\begin{array}{c}84.6 \pm 0.9 \\
(8.3)\end{array}$ & $66.1 \pm 1.7$ & $53.0 \pm 1.6$ & $48.9 \pm 0.7$ & $45.6 \pm 0.6$ \\
\hline \multirow{2}{*}{$12 d$} & 10 & $20.5 \pm 1.2$ & $30.9 \pm 3.0$ & - & $25.3 \pm 1.5$ & - & - & - & - \\
\hline & 30 & $29.0 \pm 2.0$ & $45.9 \pm 1.1$ & - & $64.0 \pm 1.8$ & $29.5 \pm 2.7$ & $28.9 \pm 0.9$ & - & $45.5 \pm 1.2$ \\
\hline \multirow[b]{2}{*}{$12 e$} & 10 & $86.4 \pm 0.3$ & $46.3 \pm 2.5$ & $25.5 \pm 2.0$ & $81.4 \pm 1.9$ & $61.1 \pm 1.6$ & $41.5 \pm 2.0$ & $49.8 \pm 0.7$ & $47.5 \pm 0.7$ \\
\hline & 30 & $\begin{array}{c}89.6 \pm 0.3 \\
(4.6)\end{array}$ & $72.5 \pm 1.1$ & $23.2 \pm 1.2$ & $\begin{array}{c}88.9 \pm 0.6 \\
\quad(5.4)\end{array}$ & $\begin{array}{c}63.4 \pm 0.9 \\
(6.6)\end{array}$ & $49.7 \pm 2.5$ & $48.8 \pm 0.9$ & $46.7 \pm 1.0$ \\
\hline
\end{tabular}


Table 1. Cont.

\begin{tabular}{|c|c|c|c|c|c|c|c|c|c|}
\hline \multirow{2}{*}{ Comp. } & \multirow{2}{*}{ Conc. $(\mu \mathbf{M})$} & \multicolumn{8}{|c|}{ Inhibition $(\%) \pm$ SEM $\left(\text { Calculated } \text { IC }_{50}\right)^{1}$} \\
\hline & & A2780 & Hela & SiHa & C33A & MCF-7 & T47D & MDA-MB-231 & MDA-MB-361 \\
\hline \multirow[b]{2}{*}{$13 a$} & 10 & $73.4 \pm 0.9$ & $70.0 \pm 0.7$ & $41.8 \pm 1.7$ & $80.0 \pm 0.5$ & $39.4 \pm 1.2$ & $36.6 \pm 0.7$ & $38.2 \pm 2.2$ & $65.8 \pm 1.0$ \\
\hline & 30 & $\begin{array}{c}83.8 \pm 0.8 \\
(3.0)\end{array}$ & $\begin{array}{c}90.9 \pm 0.3 \\
(5.3)\end{array}$ & $37.1 \pm 1.0$ & $\begin{array}{c}93.9 \pm 0.1 \\
(4.4)\end{array}$ & $73.8 \pm 1.1$ & $69.1 \pm 0.6$ & $59.7 \pm 1.6$ & $48.6 \pm 1.4$ \\
\hline \multirow[b]{2}{*}{$13 b$} & 10 & $54.3 \pm 0.8$ & $33.9 \pm 1.1$ & - & $26.6 \pm 1.8$ & - & $43.2 \pm 0.3$ & $36.7 \pm 1.8$ & - \\
\hline & 30 & $\begin{array}{c}81.0 \pm 0.1 \\
(9.8)\end{array}$ & $74.4 \pm 0.9$ & $49.4 \pm 0.8$ & $86.1 \pm 0.6$ & $65.6 \pm 1.9$ & $89.3 \pm 0.8$ & $56.8 \pm 1.2$ & $48.7 \pm 1.0$ \\
\hline \multirow{2}{*}{$13 c$} & 10 & - & $21.3 \pm 2.3$ & - & - & - & - & - & - \\
\hline & 30 & $52.7 \pm 1.9$ & $40.6 \pm 0.9$ & - & $41.7 \pm 1.2$ & $20.1 \pm 0.8$ & $39.4 \pm 1.7$ & $28.1 \pm 0.7$ & $25.7 \pm 2.8$ \\
\hline \multirow{2}{*}{$13 d$} & 10 & $20.0 \pm 1.9$ & $24.4 \pm 1.3$ & - & $26.1 \pm 0.9$ & - & - & - & - \\
\hline & 30 & $44.8 \pm 1.1$ & $36.9 \pm 0.8$ & $23.0 \pm 1.2$ & $66.3 \pm 0.6$ & $30.8 \pm 1.7$ & $44.4 \pm 1.7$ & $37.5 \pm 1.6$ & $40.3 \pm 2.1$ \\
\hline \multirow{2}{*}{$13 e$} & 10 & - & - & - & - & - & - & - & - \\
\hline & 30 & $29.1 \pm 2.3$ & $48.3 \pm 2.0$ & - & $34.2 \pm 1.3$ & - & $22.8 \pm 1.9$ & - & - \\
\hline \multirow[b]{2}{*}{ Cisplatin } & 10 & $83.6 \pm 1.2$ & $42.6 \pm 2.3$ & $88.6 \pm 0.5$ & $83.8 \pm 0.8$ & $66.9 \pm 1.8$ & $51.0 \pm 2.0$ & - & $67.5 \pm 1.0$ \\
\hline & 30 & $95.0 \pm 0.3$ & $99.9 \pm 0.3$ & $90.2 \pm 1.8$ & $94.0 \pm 0.6$ & $96.8 \pm 0.4$ & $57.9 \pm 1.5$ & $71.5 \pm 1.2$ & $87.8 \pm 1.1$ \\
\hline
\end{tabular}

': Mean value from two independent determinations with five parallel wells; standard deviation $<15 \%{ }^{2}$ : Inhibition values $<20 \%$ are not presented. 
All the CuAACs furnished the triazoles 12a-e or 13a-e in excellent yields. The orientation of the angular methyl group and the substitution pattern of the $N$-benzyl ring did not influence the yields of the reactions, as it was expected.

From the comparison of the ${ }^{1} \mathrm{H}-\mathrm{NMR}$ spectra of the 3-benzyl ethers $\mathbf{1}$ and $\mathbf{6}$ with those of their phenolic counterparts 7 and $\mathbf{8}$, the absence of the proton signals of the benzylic protecting group from the aromatic region, and the presence of the singlet at around $9 \mathrm{ppm}$ clearly indicates the successful removal of the protecting group. In the ${ }^{1} \mathrm{H}-\mathrm{NMR}$ spectra of $\mathbf{9}$ and $\mathbf{1 0}$, the introduction of the propargyl group onto the $3-\mathrm{O}$ is supported by the singlet at $2.5 \mathrm{ppm}$, which relates to the terminal alkyne function, and by the singlet of double intensity (the $\mathrm{OCH}_{2}$ group of the ether function). In the ${ }^{13} \mathrm{C}-\mathrm{NMR}$ spectra of the triazoles 12a-e and $\mathbf{1 3} \mathbf{a}-\mathbf{e}$, the two $\mathrm{OCH}_{2}$ and the $\mathrm{NCH}_{2}$ carbon signals appear in the 55-70 ppm range, indicating the presence of the $\mathrm{N}$-benzyltriazolylmethoxy moiety on $\mathrm{C}-3$. There are additional quaternary carbon signals in the aromatic region of the spectra of the triazoles, belonging to the newly introduced moiety. As concerns the epimeric character of the triazoles, C-18 in the $13 \beta$ epimers 12a-e appears at higher chemical shift ( $25 \mathrm{ppm})$ than that in the $13 \alpha$ counterparts $13 \mathbf{a}-\mathbf{e}(\sim 16 \mathrm{ppm})$.

The results of the MTT assays of the 3-OH 7 and 8 or 3-ether compounds 1, 6, 9 and 10 revealed their substantially lower inhibitory properties than those of some triazoles (Table 1). 3-OH derivatives 7, 8 exerted the lowest growth inhibition, thus the presence of the phenolic $\mathrm{OH}$ function in the D-secoestrone seems to be disadvantageous. A bulky apolar benzyl or a smaller propargyl ether protecting group on C-3 improved the antiproliferative behavior, leading to values $>80 \%$ or $>50 \%$ being attained at $30 \mu \mathrm{M}$. Introduction of a triazolylmethyl linker between the oxygen on C-3 and the benzyl protecting group seemed to be beneficial in both C-13 epimer series. As concerns the triazoles 12a-e and 13a-e, the $13 \beta$ epimers 12a-e displayed overall higher inhibitions than their $13 \alpha$ counterparts 13a-e. In both series, the most potent derivative 12a or 13a was that bearing an unsubstituted $N$-benzyl group, as observed earlier in the case of the D-secooxime 3 [11]. The characterization of the mechanism of the antiproliferative action of 12a on the three cervical cancer cell lines in under publication [23]. However, 12a displayed unusual behavior against the panel of breast cancer cell lines, with inhibition levels $<75 \%$ even at $30 \mu \mathrm{M}$. It can be stated that the presence of an electron-donating $p$-alkyl or an electron-withdrawing $p$-nitro substituent on the $N$-benzyl ring of the triazoles $12 c-\mathbf{e}$ and $13 c-\mathbf{e}$ usually proved to be detrimental for biological activity. The inhibitory effects decreased as the size of the $p$-alkyl moiety increased. It may be noted that to date there have been no reports of the $13 \alpha$-D-secoestrone derivatives with high antitumor activity.

The majority of cervical carcinomas originate from high-risk human papillomavirus (HPV) infections of the epithelial layer of the cervix, including HPV-16, -18, -31 and -35 among others [24]. HeLa is known to be an HPV-18-positive cell line [25]. SiHa and C33A differ in HPV-16 status, since only $\mathrm{SiHa}$ is infected by it. This pathological difference may cause a difference in antiproliferative action of the compounds against these cell lines. Our test compounds did not significantly influence the proliferation of SiHa cells, except in the cases of two ethers of the $13 \beta$ epimer $\mathbf{1}$ or $\mathbf{9}$, with values of $>80 \%$ at $30 \mu \mathrm{M}$. However, several triazoles were similarly potent against HeLa or C33A, independently of the HPV status of the cell lines.

Substantial differences in the growth-inhibitory potential of compound $\mathbf{1}$ were determined against a panel of breast cancer cell lines differing in receptor status [26]. These cell lines included T47D (expressing the estrogen, progesterone and androgen receptors), MDA-MB-361 (expressing the estrogen receptor and HER2) and a triple-negative cell line, MDA-MB-231. Compound 1 proved to be selective against cell line MCF-7. Since the other test compounds displayed similar activities against this cell line panel, the receptor status of the cells seems irrelevant, as we earlier observed for certain recently published D-homoestrones [27].

The cancer selectivity of one of the most promising compounds 12a was tested by means of the same MTT assay, using non-cancerous human fibroblast cells MRC5. Compound 12a elicited growth inhibition of $24.9 \% \pm 4.9 \%$ (mean \pm SEM) when applied at a final concentration of $30 \mu \mathrm{M}$. The reference agent cisplatin at the same concentration caused a more substantial inhibition $(70.7 \% \pm 1.3 \%)$. 
On the basis of these results, it could be concluded that the selected compound displays limited growth-inhibitory action against these non-cancerous cells, indicating some selective toxicity towards fast growing cancer cells.

\section{Materials and Methods}

\subsection{General Information}

Melting points ( $\mathrm{mp}$ ) were determined with a Kofler hot-stage apparatus and are uncorrected. Elemental analyses were performed with a CHN analyzer model 2400 (Perkin-Elmer, Waltham, MA, USA). Thin-layer chromatography: silica gel $60 \mathrm{~F}_{254}$; layer thickness $0.2 \mathrm{~mm}$ (Merck, New York, NY, USA); eluents: (A) 2\% ethyl acetate/98\% dichloromethane, (B) 10\% ethyl acetate/90\% dichloromethane; detection with iodine or UV (365 nm) after spraying with 5\% phosphomolybdic acid in $50 \%$ aqueous phosphoric acid and heating at $100-120^{\circ} \mathrm{C}$ for $10 \mathrm{~min}$. Flash chromatography: silica gel $60,40-63 \mu \mathrm{m}$ (Merck). ${ }^{1} \mathrm{H}-\mathrm{NMR}$ spectra were recorded in $\mathrm{CDCl}_{3}$ solution (if not otherwise stated) with a DRX-500 instrument (Bruker, Billerica, MA, USA) at $500 \mathrm{MHz}$, with $\mathrm{Me}_{4} \mathrm{Si}$ as internal standard. ${ }^{13} \mathrm{C}-\mathrm{NMR}$ spectra were recorded with the same instrument at $125 \mathrm{MHz}$ under the same conditions.

\subsection{Chemistry}

\subsubsection{General Procedure for the Synthesis of 3-Benzyloxy-D-secoalcohols 1, 6}

D-secoaldehyde 4 or 5 [10] (374 mg, $1.00 \mathrm{mmol}$ ) was dissolved in a 1:1 mixture of dichloromethane and methanol $(10 \mathrm{~mL})$ in an ice-water bath and potassium borohydride $(270 \mathrm{mg}, 5.00 \mathrm{mmol})$ was added in small portions. The mixture was allowed to stand at room temperature for $0.5 \mathrm{~h}$, then diluted with water and extracted with dichloromethane. The combined organic phases were washed with water until neutral and dried over sodium sulfate. The crude product was subjected to flash chromatography with dichloromethane as eluent.

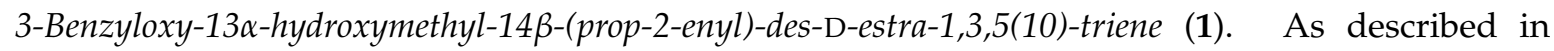
Section 4.2 .1 , D-secoaldehyde $4(374 \mathrm{mg}, 1.00 \mathrm{mmol})$ was reacted with potassium borohydride ( $270 \mathrm{mg}, 5.00 \mathrm{mmol})$. Compound 1 is identical with the compound described in the literature [10]: oil, $\mathrm{R}_{\mathrm{f}}=0.53(\mathrm{~A}) .{ }^{1} \mathrm{H}-\mathrm{NMR} \delta \mathrm{ppm} 0.80\left(\mathrm{~s}, 3 \mathrm{H}, 18-\mathrm{H}_{3}\right), 2.85\left(\mathrm{~m}, 2 \mathrm{H}, 6-\mathrm{H}_{2}\right), 3.30$ and $3.61(2 \times \mathrm{m}, 2 \times 1 \mathrm{H}$, $\left.17-\mathrm{H}_{2}\right), 5.03\left(\mathrm{~m}, 2 \mathrm{H}, 16 \mathrm{a}-\mathrm{H}_{2}\right), 5.04\left(\mathrm{~s}, 2 \mathrm{H}, \mathrm{OCH}_{2}\right), 5.93(\mathrm{~m}, 1 \mathrm{H}, 16-\mathrm{H}), 6.73(\mathrm{~d}, 1 \mathrm{H}, J=2.3 \mathrm{~Hz}, 4-\mathrm{H}), 6.79$ $(\mathrm{dd}, 1 \mathrm{H}, J=8.5 \mathrm{~Hz}, J=2.3 \mathrm{~Hz}, 2-\mathrm{H}), 7.22(\mathrm{~d}, 1 \mathrm{H}, J=8.5 \mathrm{~Hz}, 1-\mathrm{H}), 7.32\left(\mathrm{t}, 1 \mathrm{H}, J=7.3 \mathrm{~Hz}, 4^{\prime}-\mathrm{H}\right), 7.38(\mathrm{t}$, $2 \mathrm{H}, J=7.3 \mathrm{~Hz}, 3^{\prime}-\mathrm{H}$ and $\left.5^{\prime}-\mathrm{H}\right), 7.43\left(\mathrm{~d}, 2 \mathrm{H}, J=7.3 \mathrm{~Hz}, 2^{\prime}-\mathrm{H}\right.$ and $\left.6^{\prime}-\mathrm{H}\right)$.

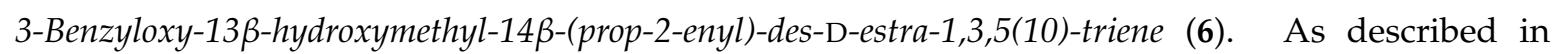
Section 4.2.1, D-secoaldehyde $5(374 \mathrm{mg}, 1.00 \mathrm{mmol})$ was reacted with potassium borohydride $(270 \mathrm{mg}$, $5.00 \mathrm{mmol})$. Compound 6 was obtained as a white solid. Yield: $347 \mathrm{mg}(92 \%) . \mathrm{Mp} \mathrm{50-52}{ }^{\circ} \mathrm{C}$, $\mathrm{R}_{\mathrm{f}}=0.47$ (A). Anal. Calcd. for $\mathrm{C}_{26} \mathrm{H}_{32} \mathrm{O}_{2}: \mathrm{C}, 82.94 ; \mathrm{H}, 8.57$. Found: C, 83.05; H, 8.66. ${ }^{1} \mathrm{H}-\mathrm{NMR}$ $\delta$ ppm $1.06\left(\mathrm{~s}, 3 \mathrm{H}, 18-\mathrm{H}_{3}\right) ; 2.82\left(\mathrm{~m}, 2 \mathrm{H}, 6-\mathrm{H}_{2}\right) ; 3.53$ and $3.72\left(2 \times \mathrm{d}, 2 \times 1 \mathrm{H}, J=10.8 \mathrm{~Hz}, 17-\mathrm{H}_{2}\right) ; 4.96-5.07$ (overlapping multiplets, $\left.4 \mathrm{H}, 16 \mathrm{a}-\mathrm{H}_{2}, \mathrm{OCH}_{2}\right) ; 5.87(\mathrm{~m}, 1 \mathrm{H}, 16-\mathrm{H}) ; 6.71(\mathrm{~s}, 1 \mathrm{H}, 4-\mathrm{H}) ; 6.79(\mathrm{~d}, 1 \mathrm{H}, J=8.3 \mathrm{~Hz}$, 2-H); $7.21(\mathrm{~d}, 1 \mathrm{H}, J=8.3 \mathrm{~Hz}, 1-\mathrm{H}) ; 7.32\left(\mathrm{t}, 1 \mathrm{H}, J=6.9 \mathrm{~Hz}, 4^{\prime}-\mathrm{H}\right) ; 7.38\left(\mathrm{t}, 2 \mathrm{H}, J=7.1 \mathrm{~Hz}, 3^{\prime}-\mathrm{H}\right.$ and $\left.5^{\prime}-\mathrm{H}\right)$; $7.42\left(\mathrm{~d}, 2 \mathrm{H}, \mathrm{J}=6.7 \mathrm{~Hz}, 2^{\prime}-\mathrm{H}\right.$ and $\left.6^{\prime}-\mathrm{H}\right),{ }^{13} \mathrm{C}-\mathrm{NMR} \delta$ ppm $25.3(\mathrm{C}-18) ; 26.5 ; 27.8 ; 30.3 ; 32.4 ; 35.6 ; 38.8 ; 41.2 ;$ 43.7; 50.7; 64.5 (C-17); $69.9\left(\mathrm{OCH}_{2}\right) ; 112.4(\mathrm{C}-2) ; 114.5(\mathrm{C}-4) ; 114.6(\mathrm{C}-16 \mathrm{a}) ; 126.3(\mathrm{C}-1) ; 127.4\left(2 \mathrm{C}: \mathrm{C}-3^{\prime}, 5^{\prime}\right)$; 127.8; 128.5 (2C:C-2' ,6'); $133.0\left(\mathrm{C}-4^{\prime}\right) ; 137.3$ (C-10); 137.9 (C-5); 140.2 (C-16); 156.8 (C-3).

\subsubsection{General Procedure for the Synthesis of 3-Hydroxy-D-secoestrones 7, 8}

A suspension of 1 or $6(376 \mathrm{mg}, 1.00 \mathrm{mmol})$ and Pd/C (0.30 g, 10\%) in ethyl acetate $(20 \mathrm{~mL})$ was subjected to 20 bar of hydrogen pressure at room temperature for $3 \mathrm{~h}$. The catalyst was then removed by filtration through a short pad of silica gel. After evaporation of the solvent in vacuo, the crude product was subjected to flash chromatography with dichloromethane as eluent. 


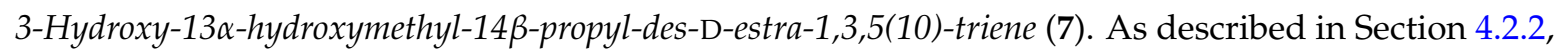
compound 1 (376 mg, $1.00 \mathrm{mmol})$ was subjected to hydrogenolysis. Compound 7 is identical with compound described in the literature [10]: $\mathrm{Mp} 60-62{ }^{\circ} \mathrm{C}, \mathrm{R}_{\mathrm{f}}=0.17(\mathrm{~A}) .{ }^{1} \mathrm{H}-\mathrm{NMR} \delta \mathrm{ppm} 0.77(\mathrm{~s}, 3 \mathrm{H}$, $\left.18-\mathrm{H}_{3}\right), 2.82\left(\mathrm{~m}, 2 \mathrm{H}, 6-\mathrm{H}_{2}\right), 3.35$ and $3.52\left(2 \times \mathrm{d}, 2 \times 1 \mathrm{H}, \mathrm{J}=10.9 \mathrm{~Hz}, 17-\mathrm{H}_{2}\right), 6.56(\mathrm{~d}, 1 \mathrm{H}, \mathrm{J}=2.3 \mathrm{~Hz}, 4-\mathrm{H})$, $6.63(\mathrm{dd}, 1 \mathrm{H}, J=8.5 \mathrm{~Hz}, J=2.3 \mathrm{~Hz}, 2-\mathrm{H}), 7.16(\mathrm{~d}, 1 \mathrm{H}, J=8.5 \mathrm{~Hz}, 1-\mathrm{H})$.

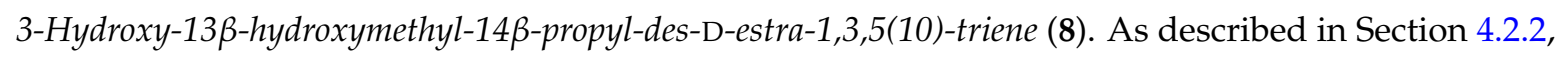
compound 6 (376 mg, $1.00 \mathrm{mmol}$ ) was subjected to hydrogenolysis. The chromatographic purification of the crude product yielded 8 as a white solid (268 mg, 93\%). Mp 50-52 ${ }^{\circ} \mathrm{C}, \mathrm{R}_{\mathrm{f}}=0.27$ (A). Anal. Calcd. for $\mathrm{C}_{19} \mathrm{H}_{28} \mathrm{O}_{2}$ : C, 79.12; H, 9.78. Found: $C, 79.25 ; \mathrm{H}, 9.96$. DMSO- $d_{6}{ }^{1} \mathrm{H}-\mathrm{NMR} \delta \mathrm{ppm} 0.89(\mathrm{t}, 3 \mathrm{H}$, $\left.J=6.7 \mathrm{~Hz}, 16 \mathrm{a}-\mathrm{H}_{3}\right) ; 1.17\left(\mathrm{~s}, 3 \mathrm{H}, 18-\mathrm{H}_{3}\right) ; 2.69\left(\mathrm{~m}, 2 \mathrm{H}, 6-\mathrm{H}_{2}\right) ; 3.19$ and $3.48\left(2 \times \mathrm{m}, 2 \times 1 \mathrm{H}, 17-\mathrm{H}_{2}\right) ; 4.18(\mathrm{~s}$, $1 \mathrm{H}, 17-\mathrm{OH}) ; 6.41(\mathrm{~s}, 1 \mathrm{H}, 4-\mathrm{H}) ; 6.50(\mathrm{dd}, 1 \mathrm{H}, J=1.76 \mathrm{~Hz}, J=8.2 \mathrm{~Hz}, 2-\mathrm{H}) ; 7.04(\mathrm{~d}, 1 \mathrm{H}, J=8.5 \mathrm{~Hz}, 1-\mathrm{H})$; 8.96 (s, 1H, 3-OH), ${ }^{13} \mathrm{C}-\mathrm{NMR} \delta$ ppm 14.4 (C-16a); 25.0; 25.2 (C-18); 26.3; 27.4; 29.8; 30.3; 35.1; 38.0; 41.3; 43.2; 50.8; 61.5 (C-17); 112.7 (C-2); 114.5 (C-4); 126.0 (C-1); 130.6 (C-10); 136.9 (C-5); 154.8 (C-3).

\subsubsection{General Procedure for the Synthesis of 3-(Prop-2-inyloxy)-D-secoestrones 9, 10}

3-Hydroxy-D-secoalcohol 7 or 8 (288 mg, $1.00 \mathrm{mmol})$ was dissolved in acetone $(10 \mathrm{~mL})$, propargyl bromide (0.17 $\mathrm{mL}$ (80 wt \% in toluene), $1.50 \mathrm{mmol})$ and potassium carbonate $(968 \mathrm{mg}, 7.00 \mathrm{mmol})$ were added. The reaction mixture was stirred at $70{ }^{\circ} \mathrm{C}$ for $24 \mathrm{~h}$, the solvent was evaporated off, and the residue was subjected to flash chromatography with $2 \%$ ethyl acetate $/ 98 \%$ dichloromethane as eluent.

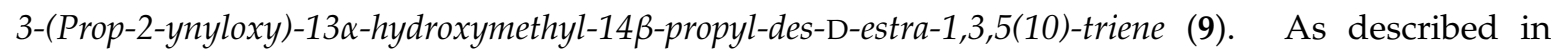
Section 4.2.3, 3-hydroxy-D-secoalcohol 7 (288 mg, $1.00 \mathrm{mmol})$ was reacted with propargyl bromide (0.17 $\mathrm{mL}$ (80 wt \% in toluene), $1.50 \mathrm{mmol})$. Compound 9 was obtained as a white solid $(280 \mathrm{mg}, 86 \%)$. $\mathrm{Mp} 41-43{ }^{\circ} \mathrm{C}, \mathrm{R}_{\mathrm{f}}=0.40$ (A). Anal. Calcd. for $\mathrm{C}_{22} \mathrm{H}_{30} \mathrm{O}_{2}: \mathrm{C}, 80.94 ; \mathrm{H}, 9.26$. Found: C, 81.02; $\mathrm{H}, 9.35$. ${ }^{1} \mathrm{H}-\mathrm{NMR} \delta$ ppm $0.78\left(\mathrm{~s}, 3 \mathrm{H}, 18-\mathrm{H}_{3}\right) ; 0.92\left(\mathrm{t}, 3 \mathrm{H}, \mathrm{J}=6.9 \mathrm{~Hz}, 16 \mathrm{a}-\mathrm{H}_{3}\right) ; 2.50(\mathrm{~s}, 1 \mathrm{H}, \mathrm{C} \equiv \mathrm{CH}) ; 2.86(\mathrm{~m}, 2 \mathrm{H}$, $\left.6-\mathrm{H}_{2}\right) ; 3.34$ and $3.52\left(2 \times \mathrm{d}, 2 \times 1 \mathrm{H}, \mathrm{J}=10.9 \mathrm{~Hz}, 17-\mathrm{H}_{2}\right) ; 4.66\left(\mathrm{~s}, 2 \mathrm{H}, \mathrm{OCH}_{2}\right) ; 6.70(\mathrm{~d}, 1 \mathrm{H}, \mathrm{J}=2.3 \mathrm{~Hz}, 4-\mathrm{H})$; $6.79(\mathrm{dd}, 1 \mathrm{H}, J=8.5 \mathrm{~Hz}, J=2.3 \mathrm{~Hz}, 2-\mathrm{H}) ; 7.24(\mathrm{~d}, 1 \mathrm{H}, J=8.5 \mathrm{~Hz}, 1-\mathrm{H}),{ }^{13} \mathrm{C}-\mathrm{NMR} \delta \mathrm{ppm} 14.7$ (C-16a); 15.9 (C-18); $25.0 ; 26.4 ; 27.5 ; 30.7 ; 31.2 ; 35.6 ; 38.7 ; 41.7 ; 43.5 ; 45.2 ; 55.7$ and $71.3\left(2 \times \mathrm{OCH}_{2}\right) ; 74.9(\mathrm{C} \equiv \underline{\mathrm{CH}})$; $78.5(\mathrm{C} \equiv \mathrm{CH}) ; 112.4$ (C-2); 114.5 (C-4); 126.6 (C-1); 133.8 (C-10); 138.1 (C-5); 155.4 (C-3).

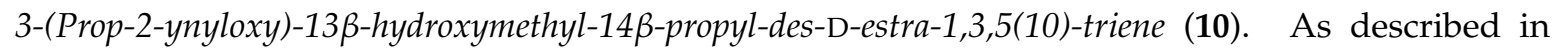
Section 4.2.3, 3-hydroxy-D-secoalcohol $8(288 \mathrm{mg}, 1.00 \mathrm{mmol})$ was reacted with propargylbromide (0.17 mL (80 wt \% in toluene), $1.50 \mathrm{mmol})$. Compound 10 was obtained as a white solid $(271 \mathrm{mg}, 83 \%)$. $\mathrm{Mp} \mathrm{41-43}{ }^{\circ} \mathrm{C}, \mathrm{R}_{\mathrm{f}}=0.50$ (A). Anal. Calcd. for $\mathrm{C}_{22} \mathrm{H}_{30} \mathrm{O}_{2}: \mathrm{C}, 80.94 ; \mathrm{H}, 9.26$. Found: C, 80.87; $\mathrm{H}, 9.42$. ${ }^{1} \mathrm{H}-\mathrm{NMR} \delta$ ppm $0.92\left(\mathrm{t}, 3 \mathrm{H}, J=6.9 \mathrm{~Hz}, 16 \mathrm{a}-\mathrm{H}_{3}\right) ; 1.03\left(\mathrm{~s}, 3 \mathrm{H}, 18-\mathrm{H}_{3}\right) ; 2.50(\mathrm{~s}, 1 \mathrm{H}, \mathrm{C} \equiv \mathrm{CH}) ; 2.84(\mathrm{~m}, 2 \mathrm{H}$, $\left.6-\mathrm{H}_{2}\right) ; 3.47$ and $3.73\left(2 \times \mathrm{d}, 2 \times 1 \mathrm{H}, \mathrm{J}=10.9 \mathrm{~Hz}, 17-\mathrm{H}_{2}\right) ; 4.65\left(\mathrm{~s}, 2 \mathrm{H}, \mathrm{OCH}_{2}\right) ; 6.68(\mathrm{~d}, 1 \mathrm{H}, \mathrm{J}=2.3 \mathrm{~Hz}, 4-\mathrm{H})$; $6.78(\mathrm{dd}, 1 \mathrm{H}, J=8.5 \mathrm{~Hz}, J=2.3 \mathrm{~Hz}, 2-\mathrm{H}) ; 7.22(\mathrm{~d}, 1 \mathrm{H}, J=8.5 \mathrm{~Hz}, 1-\mathrm{H}),{ }^{13} \mathrm{C}-\mathrm{NMR} \delta \mathrm{ppm} 14.6(\mathrm{C}-16 \mathrm{a})$; 24.9 (C-18); 25.5; 26.6; 27.7; 30.6; 31.0; 35.2; 38.6; 41.7; 43.7; 51.4; 55.7 and $64.1\left(2 \times \mathrm{OCH}_{2}\right) ; 75.2(\mathrm{C} \equiv \underline{\mathrm{CH}})$; 78.9 ( $\underline{\mathrm{C}} \mathrm{CH}) ; 112.4(\mathrm{C}-2) ; 114.5$ (C-4); 126.5 (C-1); 133.8 (C-10); 137.9 (C-5); $155.4(\mathrm{C}-3)$.

\subsubsection{General Procedure for the "Click" Reaction}

To a stirred solution of 3-(prop-2-inlyoxy)-D-secoalcohol 9 or 10 (326 mg, $1.00 \mathrm{mmol}$ ) in toluene (5 mL), $\mathrm{PPh}_{3}(52 \mathrm{mg}, 0.20 \mathrm{mmol}), \mathrm{CuI}(19 \mathrm{mg}, 0.10 \mathrm{mmol}), \mathrm{DIPEA}(0.52 \mathrm{ml}, 3.00 \mathrm{mmol})$ and the appropriate benzyl azide 11 (1 equiv., see [28-31] for their preparation) were added. The reaction mixture was refluxed for $2 \mathrm{~h}$, allowed to cool and evaporated in vacuo. The residue 12a-e, 13a-e was purified by flash chromatography with $10 \%$ ethyl acetate $/ 90 \%$ dichloromethane as eluent.

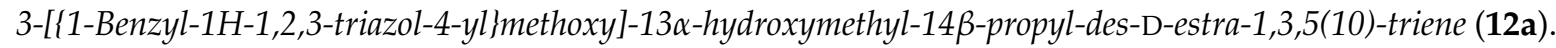
As described in Section 4.2.4, alkyne $9(326 \mathrm{mg}, 1.00 \mathrm{mmol})$ was reacted with benzyl azide $11 \mathrm{a}(133 \mathrm{mg}$, $1.0 \mathrm{mmol})$. Yield: $428 \mathrm{mg}(93 \%)$. Mp $41-43{ }^{\circ} \mathrm{C}, \mathrm{R}_{\mathrm{f}}=0.46$ (B). Anal. Calcd. for $\mathrm{C}_{29} \mathrm{H}_{37} \mathrm{~N}_{3} \mathrm{O}_{2}: \mathrm{C}_{7} 75.78$; H, 8.11. Found: C, 75.94; H, 8.25. ${ }^{1} \mathrm{H}-\mathrm{NMR} \delta \mathrm{ppm} 0.77\left(\mathrm{~s}, 3 \mathrm{H}, 18-\mathrm{H}_{3}\right) ; 0.92\left(\mathrm{t}, 3 \mathrm{H}, J=6.9 \mathrm{~Hz}, 16 \mathrm{a}-\mathrm{H}_{3}\right)$; 
$2.84\left(\mathrm{~m}, 2 \mathrm{H}, 6-\mathrm{H}_{2}\right) ; 3.34$ and $3.52\left(2 \times \mathrm{d}, 2 \times 1 \mathrm{H}, J=10.9 \mathrm{~Hz}, 17-\mathrm{H}_{2}\right) ; 5.16\left(\mathrm{~s}, 2 \mathrm{H}, \mathrm{OCH}_{2}\right) ; 5.53(\mathrm{~s}, 2 \mathrm{H}$, $\left.\mathrm{NCH}_{2}\right) ; 6.69(\mathrm{~d}, 1 \mathrm{H}, J=2.3 \mathrm{~Hz}, 4-\mathrm{H}) ; 6.77(\mathrm{dd}, 1 \mathrm{H}, J=8.5 \mathrm{~Hz}, J=2.3 \mathrm{~Hz}, 2-\mathrm{H}) ; 7.21(\mathrm{~d}, 1 \mathrm{H}, J=8.5 \mathrm{~Hz}$, $1-\mathrm{H}) ; 7.28\left(\mathrm{dd}, 2 \mathrm{H}, J=8.6 \mathrm{~Hz}, J=2.9 \mathrm{~Hz}, 2^{\prime}-\mathrm{H}\right.$ and $\left.6^{\prime}-\mathrm{H}\right), 7.38$ (overlapping multiplets, $3 \mathrm{H}, 3^{\prime}-\mathrm{H}, 4^{\prime}-\mathrm{H}$ and $\left.5^{\prime}-\mathrm{H}\right) ; 7.52(\mathrm{~s}, 1 \mathrm{H}, \mathrm{C}=\mathrm{CH}),{ }^{13} \mathrm{C}-\mathrm{NMR} \delta \mathrm{ppm} 14.6$ (C-18); 16.0 (C-16a); 25.0; 26.4; 27.4; 30.6; 31.2; 35.6; 38.7; 41.7; 43.5; 45.2; $54.2\left(\mathrm{NCH}_{2}\right) ; 62.1\left(\mathrm{OCH}_{2}\right) ; 71.3(\mathrm{C}-17) ; 112.4(\mathrm{C}-2) ; 114.4(\mathrm{C}-4) ; 122.5(\mathrm{C}=\mathrm{CH}) ; 126.6$ (C-1); 128.1 (2C: C-3', $\left.5^{\prime}\right) ; 128.8\left(\mathrm{C}-4^{\prime}\right) ; 129.1$ (2C: C-2', $\left.6^{\prime}\right) ; 133.5$ (C-10); $134.4\left(\mathrm{C}-1^{\prime}\right) ; 138.1$ (C-5); 144.9 $(\mathrm{C}=\mathrm{CH}) ; 156.0(\mathrm{C}-3)$.

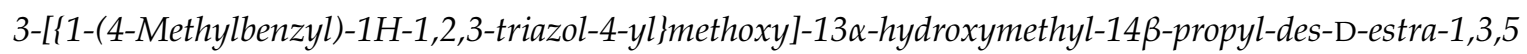
(10)-triene (12b). As described in Section 4.2.4, alkyne $9(326 \mathrm{mg}, 1.00 \mathrm{mmol}$ ) was reacted with 4-methylbenzyl azide $11 \mathrm{~b}(147 \mathrm{mg}, 1.00 \mathrm{mmol})$. Yield: $436 \mathrm{mg}(92 \%) . \mathrm{Mp} 50-52{ }^{\circ} \mathrm{C}, \mathrm{R}_{\mathrm{f}}=0.26$ (B). Anal. Calcd. for $\mathrm{C}_{30} \mathrm{H}_{39} \mathrm{~N}_{3} \mathrm{O}_{2}: \mathrm{C}, 76.07 ; \mathrm{H}, 8.30$. Found: $\mathrm{C}, 75.92 ; \mathrm{H}, 8.54 .{ }^{1} \mathrm{H}-\mathrm{NMR} \delta \mathrm{ppm} 0.77(\mathrm{~s}, 3 \mathrm{H}$, $\left.18-\mathrm{H}_{3}\right) ; 0.91\left(\mathrm{t}, 3 \mathrm{H}, J=6.9 \mathrm{~Hz}, 16 \mathrm{a}-\mathrm{H}_{3}\right) ; 2.35\left(\mathrm{~s}, 3 \mathrm{H}\right.$, tolyl $\left.-\mathrm{CH}_{3}\right) ; 2.83\left(\mathrm{~m}, 2 \mathrm{H}, 6-\mathrm{H}_{2}\right) ; 3.34$ and $3.52(2 \times \mathrm{d}$, $\left.2 \times 1 \mathrm{H}, J=10.9 \mathrm{~Hz}, 17-\mathrm{H}_{2}\right) ; 5.15\left(\mathrm{~s}, 2 \mathrm{H}, \mathrm{OCH}_{2}\right) ; 5.48\left(\mathrm{~s}, 2 \mathrm{H}, \mathrm{NCH}_{2}\right) ; 6.68(\mathrm{~d}, 1 \mathrm{H}, J=2.3 \mathrm{~Hz}, 4-\mathrm{H}) ; 6.76$ $(\mathrm{dd}, 1 \mathrm{H}, J=8.5 \mathrm{~Hz}, J=2.3 \mathrm{~Hz}, 2-\mathrm{H}) ; 7.17-7.20$ (overlapping multiplets, $6 \mathrm{H}, 1-\mathrm{H}, \mathrm{C}=\mathrm{CH}, 2^{\prime}-\mathrm{H}, 3^{\prime}-\mathrm{H}, 5^{\prime}-\mathrm{H}$ and $\left.6^{\prime}-\mathrm{H}\right),{ }^{13} \mathrm{C}-\mathrm{NMR} \delta \mathrm{ppm} 14.6$ (C-18); 15.9 (C-16a); 21.1 (tolyl- $\left.\mathrm{CH}_{3}\right) ; 24.9 ; 26.4 ; 27.4 ; 30.6 ; 31.2 ; 35.6$; $38.7 ; 41.7 ; 43.5 ; 45.3 ; 54.2\left(\mathrm{NCH}_{2}\right) ; 62.1\left(\mathrm{OCH}_{2}\right) ; 71.3(\mathrm{C}-17) ; 112.4(\mathrm{C}-2) ; 114.4(\mathrm{C}-4) ; 122.4(\mathrm{C}=\mathrm{CH}) ; 126.5$ (C-1); $128.2\left(2 \mathrm{C}: \mathrm{C}-3^{\prime}, 5^{\prime}\right) ; 129.7\left(2 \mathrm{C}: \mathrm{C}-2^{\prime}, 6^{\prime}\right) ; 131.3$ and $133.5(\mathrm{C}-10$ and C-4' $) ; 138.1(\mathrm{C}-5) ; 138.7\left(\mathrm{C}-1^{\prime}\right)$; $144.7(\underline{\mathrm{C}}=\mathrm{CH}) ; 156.0(\mathrm{C}-3)$.

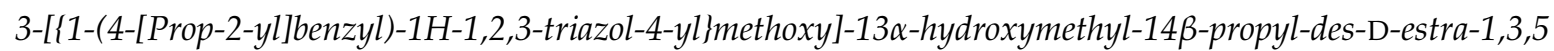
(10)-triene (12c). As described in Section 4.2.4, alkyne 9 (326 mg, $1.00 \mathrm{mmol}$ ) was reacted with 4-(prop-2-yl)-benzyl azide 11c (175 mg, $1.00 \mathrm{mmol}$ ). Yield: $452 \mathrm{mg}(90 \%) . \mathrm{Mp} 41-43^{\circ} \mathrm{C}, \mathrm{R}_{\mathrm{f}}=0.30$ (B). Anal. Calcd. for $\mathrm{C}_{32} \mathrm{H}_{43} \mathrm{~N}_{3} \mathrm{O}_{2}: \mathrm{C}, 76.61 ; \mathrm{H}, 8.64$. Found: $\mathrm{C}, 76.85 ; \mathrm{H}, 8.76 .{ }^{1} \mathrm{H}-\mathrm{NMR} \delta \mathrm{ppm} 0.77(\mathrm{~s}, 3 \mathrm{H}$, $\left.18-\mathrm{H}_{3}\right) ; 0.91\left(\mathrm{t}, 3 \mathrm{H}, J=6.9 \mathrm{~Hz}, 16 \mathrm{a}-\mathrm{H}_{3}\right) ; 1.24\left(\mathrm{~d}, 6 \mathrm{H}, 2 \times\right.$ prop-2-yl- $\left.\mathrm{CH}_{3}\right) ; 2.83\left(\mathrm{~m}, 2 \mathrm{H}, 6-\mathrm{H}_{2}\right) ; 3.33$ and 3.52 $\left(2 \times \mathrm{d}, 2 \times 1 \mathrm{H}, J=10.9 \mathrm{~Hz}, 17-\mathrm{H}_{2}\right) ; 5.19\left(\mathrm{~s}, 2 \mathrm{H}, \mathrm{OCH}_{2}\right) ; 5.50\left(\mathrm{~s}, 2 \mathrm{H}, \mathrm{NCH}_{2}\right) ; 6.68(\mathrm{~d}, 1 \mathrm{H}, J=2.3 \mathrm{~Hz}, 4-\mathrm{H})$; $6.75(\mathrm{dd}, 1 \mathrm{H}, J=8.5 \mathrm{~Hz}, J=2.3 \mathrm{~Hz}, 2-\mathrm{H}) ; 7.22-7.24$ (overlapping multiplets, 5H, 1-H, $2^{\prime}-\mathrm{H}, 3^{\prime}-\mathrm{H}, 5^{\prime}-\mathrm{H}$ and $\left.6^{\prime}-\mathrm{H}\right) ; 7.55(\mathrm{~s}, 1 \mathrm{H}, \mathrm{C}=\mathrm{CH}),{ }^{13} \mathrm{C}-\mathrm{NMR} \delta \mathrm{ppm} 14.6$ and $15.9(\mathrm{C}-18$ and $\mathrm{C}-16 \mathrm{a}) ; 23.8\left(2 \mathrm{C}: \mathrm{CH}\left(\mathrm{CH}_{3}\right)_{2}\right)$; $24.9 ; 26.4 ; 27.4 ; 30.6 ; 31.2 ; 33.8\left(\underline{\mathrm{CH}}\left(\mathrm{CH}_{3}\right)_{2}\right) ; 35.6 ; 38.7 ; 41.7 ; 43.5 ; 45.2 ; 54.0\left(\mathrm{NCH}_{2}\right) ; 62.0\left(\mathrm{OCH}_{2}\right) ; 71.2$ (C-17); $112.3(\mathrm{C}-2) ; 114.3(\mathrm{C}-4) ; 122.5(\mathrm{C}=\mathrm{CH}) ; 126.5(\mathrm{C}-1) ; 127.1$ (2C: $\left.\mathrm{C}-3^{\prime}, 5^{\prime}\right) ; 128.2\left(2 \mathrm{C}: \mathrm{C}-2^{\prime}, 6^{\prime}\right) ; 131.7$ (C-1'); 133.5 (C-10); 138.1 (C-5); 144.7 (C-4'); 149.6 ( $\mathrm{C}=\mathrm{CH}) ; 156.1$ (C-3).

3-[\{1-(4-tert-Butylbenzyl)-1H-1,2,3-triazol-4-yl\}methoxy]-13 $\alpha$-hydroxymethyl-14 $\beta$-propyl-des-D-estra-1,3,5 (10)-triene (12d). As described in Section 4.2.4, alkyne $9(326 \mathrm{mg}, 1.00 \mathrm{mmol}$ ) was reacted with 4-tert-butylbenzyl azide 11d (189 mg, $1.00 \mathrm{mmol})$. Yield: $475 \mathrm{mg}(92 \%) . \mathrm{Mp} 58-60{ }^{\circ} \mathrm{C}, \mathrm{R}_{\mathrm{f}}=0.32(\mathrm{~B})$. Anal. Calcd. for $\mathrm{C}_{33} \mathrm{H}_{45} \mathrm{~N}_{3} \mathrm{O}_{2}: \mathrm{C}, 76.85 ; \mathrm{H}, 8.79$. Found: $\mathrm{C}, 75.98 ; \mathrm{H}, 8.95 .{ }^{1} \mathrm{H}-\mathrm{NMR} \delta \mathrm{ppm} 0.77(\mathrm{~s}, 3 \mathrm{H}$, $\left.18-\mathrm{H}_{3}\right) ; 0.91\left(\mathrm{t}, 3 \mathrm{H}, J=6.9 \mathrm{~Hz}, 16 \mathrm{a}-\mathrm{H}_{3}\right) ; 1.31\left(\mathrm{~s}, 9 \mathrm{H}, 3 \times{ }^{\mathrm{t}} \mathrm{Bu}^{\left.-\mathrm{CH}_{3}\right)} ; 2.83\left(\mathrm{~m}, 2 \mathrm{H}, 6-\mathrm{H}_{2}\right) ; 3.33\right.$ and $3.52(2 \times \mathrm{d}$, $\left.2 \times 1 \mathrm{H}, J=10.9 \mathrm{~Hz}, 17-\mathrm{H}_{2}\right) ; 5.18\left(\mathrm{~s}, 2 \mathrm{H}, \mathrm{OCH}_{2}\right) ; 5.50\left(\mathrm{~s}, 2 \mathrm{H}, \mathrm{NCH}_{2}\right) ; 6.68(\mathrm{~d}, 1 \mathrm{H}, J=2.3 \mathrm{~Hz}, 4-\mathrm{H}) ; 6.77$ $(\mathrm{dd}, 1 \mathrm{H}, J=8.5 \mathrm{~Hz}, J=2.3 \mathrm{~Hz}, 2-\mathrm{H}) ; 7.20-7.24$ (overlapping multiplets, $3 \mathrm{H}, 1-\mathrm{H}, 2^{\prime}-\mathrm{H}$ and $6^{\prime}-\mathrm{H}$ ); 7.39 (d, $2 \mathrm{H}, J=8.1 \mathrm{~Hz}, 3^{\prime}-\mathrm{H}$ and $\left.5^{\prime}-\mathrm{H}\right) ; 7.54(\mathrm{~s}, 1 \mathrm{H}, \mathrm{C}=\mathrm{CH}),{ }^{13} \mathrm{C}-\mathrm{NMR} \delta \mathrm{ppm} 14.7$ and 15.9 (C-18 and C-16a); $24.9 ; 26.4 ; 27.4 ; 30.7 ; 31.1\left(3 \mathrm{C}: \mathrm{C}\left(\mathrm{CH}_{3}\right)_{3}\right) ; 31.2 ; 34.6\left(\underline{\mathrm{C}}\left(\mathrm{CH}_{3}\right)_{3}\right) ; 35.6 ; 38.7 ; 41.7 ; 43.5 ; 45.2 ; 54.0\left(\mathrm{NCH}_{2}\right)$; $62.1\left(\mathrm{OCH}_{2}\right) ; 71.3(\mathrm{C}-17) ; 112.4(\mathrm{C}-2) ; 114.4(\mathrm{C}-4) ; 122.5(\mathrm{C}=\mathrm{CH}) ; 126.0\left(2 \mathrm{C}: \mathrm{C}^{\prime} 3^{\prime}, 5^{\prime}\right) ; 126.6(\mathrm{C}-1) ; 127.9$ (2C: $\left.\mathrm{C}-2^{\prime}, 6^{\prime}\right) ; 131.3\left(\mathrm{C}-1^{\prime}\right) ; 133.5(\mathrm{C}-10) ; 138.1(\mathrm{C}-5) ; 144.8\left(\mathrm{C}-4^{\prime}\right) ; 151.9(\underline{\mathrm{C}}=\mathrm{CH}) ; 156.0(\mathrm{C}-3)$.

3-[\{1-(4-Nitrobenzyl)-1H-1,2,3-triazol-4-yl\}methoxy]-13 $\alpha$-hydroxymethyl-14 $\beta$-propyl-des-D-estra-1,3,5(10) -triene (12e). As described in Section 4.2.4, alkyne 9 (326 mg, $1.00 \mathrm{mmol}$ ) was reacted with 4-nitrobenzyl azide 11e (178 mg, $1.00 \mathrm{mmol})$. Yield: $475 \mathrm{mg}, 94 \%)$. Mp 65-67 ${ }^{\circ} \mathrm{C}, \mathrm{R}_{\mathrm{f}}=0.20$ (B). Anal. Calcd. for $\mathrm{C}_{29} \mathrm{H}_{36} \mathrm{~N}_{4} \mathrm{O}_{4}: \mathrm{C}, 69.02 ; \mathrm{H}, 7.19$. Found: $\mathrm{C}, 69.15 ; \mathrm{H}, 7.02 .{ }^{1} \mathrm{H}-\mathrm{NMR} \delta \mathrm{ppm} 0.77\left(\mathrm{~s}, 3 \mathrm{H}, 18-\mathrm{H}_{3}\right) ; 0.91(\mathrm{t}$, $\left.3 \mathrm{H}, J=6.9 \mathrm{~Hz}, 16 \mathrm{a}-\mathrm{H}_{3}\right) ; 2.83\left(\mathrm{~m}, 2 \mathrm{H}, 6-\mathrm{H}_{2}\right) ; 3.34$ and $3.52\left(2 \times \mathrm{d}, 2 \times 1 \mathrm{H}, J=10.9 \mathrm{~Hz}, 17-\mathrm{H}_{2}\right) ; 5.19(\mathrm{~s}, 2 \mathrm{H}$, $\left.\mathrm{OCH}_{2}\right) ; 5.64\left(\mathrm{~s}, 2 \mathrm{H}, \mathrm{NCH}_{2}\right) ; 6.67(\mathrm{~d}, 1 \mathrm{H}, J=2.3 \mathrm{~Hz}, 4-\mathrm{H}) ; 6.76(\mathrm{dd}, 1 \mathrm{H}, J=8.5 \mathrm{~Hz}, J=2.3 \mathrm{~Hz}, 2-\mathrm{H}) ; 7.21$ $(\mathrm{d}, 1 \mathrm{H}, J=8.5 \mathrm{~Hz}, 1-\mathrm{H}) ; 7.40\left(\mathrm{~d}, 2 \mathrm{H}, J=8.6 \mathrm{~Hz}, 2^{\prime}-\mathrm{H}, 6^{\prime}-\mathrm{H}\right) ; 7.62(\mathrm{~s}, 1 \mathrm{H}, \mathrm{C}=\mathrm{CH}) ; 8.22(\mathrm{~d}, J=8.6 \mathrm{~Hz}, 2 \mathrm{H}$, $\left.3^{\prime}-\mathrm{H}, 5^{\prime}-\mathrm{H}\right),{ }^{13} \mathrm{C}-\mathrm{NMR} \delta$ ppm 14.6 (C-18); 15.9 (C-16a); 24.9; 26.4; 27.4; 30.7; 31.2; 35.6; 38.7; 41.7; 43.5; 
45.2; $53.1\left(\mathrm{NCH}_{2}\right) ; 62.0\left(\mathrm{OCH}_{2}\right) ; 71.2(\mathrm{C}-17) ; 112.3(\mathrm{C}-2) ; 114.3(\mathrm{C}-4) ; 122.8(\mathrm{CH}=\mathrm{C}) ; 124.3\left(2 \mathrm{C}: \mathrm{C}^{\prime} 3^{\prime}, 5^{\prime}\right)$; $126.6(\mathrm{C}-1) ; 128.6\left(2 \mathrm{C}: \mathrm{C}-2^{\prime}, 6^{\prime}\right) ; 133.7(\mathrm{C}-10) ; 138.2(\mathrm{C}-5) ; 141.5$ and $145.5\left(\mathrm{C}-1^{\prime}\right.$ and $\left.\mathrm{C}=\mathrm{CH}\right) ; 148.1\left(\mathrm{C}-4^{\prime}\right)$; 155.9 (C-3).

3-[\{1-Benzyl-1H-1,2,3-triazol-4-yl\}methoxy]-13 $\beta$-hydroxymethyl-14 $\beta$-propyl-des-D-estra-1,3,5(10)-triene (13a). As described in Section 4.2.4, alkyne $10(326 \mathrm{mg}, 1.00 \mathrm{mmol})$ was reacted with benzyl azide 11a (133 mg, 1.00 mmol). Yield: $437 \mathrm{mg}(95 \%)$. Oil, $\mathrm{R}_{\mathrm{f}}=0.19$ (B). Anal. Calcd. for $\mathrm{C}_{29} \mathrm{H}_{37} \mathrm{~N}_{3} \mathrm{O}_{2}: \mathrm{C}, 75.78 ; \mathrm{H}$, 8.11. Found: $\mathrm{C}, 75.93 ; \mathrm{H}, 8.02 .{ }^{1} \mathrm{H}-\mathrm{NMR} \delta \mathrm{ppm} 0.89\left(\mathrm{t}, 3 \mathrm{H}, J=7.2 \mathrm{~Hz}, 16 \mathrm{a}-\mathrm{H}_{3}\right) ; 1.00\left(\mathrm{~s}, 3 \mathrm{H}, 18-\mathrm{H}_{3}\right) ; 2.80$ $\left(\mathrm{m}, 2 \mathrm{H}, 6-\mathrm{H}_{2}\right) ; 3.44$ and $3.70\left(2 \times \mathrm{d}, 2 \times 1 \mathrm{H}, J=10.9 \mathrm{~Hz}, 17-\mathrm{H}_{2}\right) ; 5.13\left(\mathrm{~s}, 2 \mathrm{H}, \mathrm{OCH}_{2}\right) ; 5.50\left(\mathrm{~s}, 2 \mathrm{H}, \mathrm{NCH}_{2}\right)$; $6.66(\mathrm{~d}, 1 \mathrm{H}, J=2.4 \mathrm{~Hz}, 4-\mathrm{H}) ; 6.73(\mathrm{dd}, 1 \mathrm{H}, J=8.5 \mathrm{~Hz}, J=2.1 \mathrm{~Hz}, 2-\mathrm{H}) ; 7.16(\mathrm{~d}, 1 \mathrm{H}, J=8.5 \mathrm{~Hz}, 1-\mathrm{H})$; $7.24\left(\mathrm{~d}, 2 \mathrm{H}, J=7.6 \mathrm{~Hz}, 2^{\prime}-\mathrm{H}\right.$ and $\left.6^{\prime}-\mathrm{H}\right), 7.35$ (overlapping multiplets, $3 \mathrm{H}, 3^{\prime}-\mathrm{H}, 4^{\prime}-\mathrm{H}$ and $\left.5^{\prime}-\mathrm{H}\right) ; 7.51$ (s, $1 \mathrm{H}, \mathrm{C}=\mathrm{CH}),{ }^{13} \mathrm{C}-\mathrm{NMR} \delta$ ppm 14.5 (C-16a); 24.9 (C-18); 25.5; 26.6; 27.7; 30.5; 30.9; 35.2; 38.5; 41.6; 43.7; 51.4; $54.2\left(\mathrm{NCH}_{2}\right) ; 62.0$ and $64.0\left(\mathrm{OCH}_{2}\right.$ and C-17); $112.3(\mathrm{C}-2) ; 114.3(\mathrm{C}-4) ; 122.5(\mathrm{C}=\underline{\mathrm{CH}}) ; 126.5(\mathrm{C}-1)$; 128.1 (2C: C-3', $\left.5^{\prime}\right) ; 128.8\left(\mathrm{C}-4^{\prime}\right) ; 129.1\left(2 \mathrm{C}: \mathrm{C}^{\prime} 2^{\prime}, 6^{\prime}\right) ; 133.4(\mathrm{C}-10) ; 134.4\left(\mathrm{C}-1^{\prime}\right) ; 137.9(\mathrm{C}-5) ; 145.0(\underline{\mathrm{C}}=\mathrm{CH})$; $156.0(\mathrm{C}-3)$.

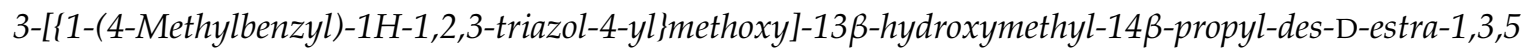
(10)-triene (13b). As described in Section 4.2.4, alkyne $10(326 \mathrm{mg}, 1.00 \mathrm{mmol}$ ) was reacted with 4-methylbenzyl azide $11 \mathrm{~b}(147 \mathrm{mg}, 1.00 \mathrm{mmol})$. Yield: $431 \mathrm{mg}(91 \%) . \mathrm{Mp} 49-51{ }^{\circ} \mathrm{C}, \mathrm{R}_{\mathrm{f}}=0.16(\mathrm{~B})$. Anal. Calcd. for $\mathrm{C}_{30} \mathrm{H}_{39} \mathrm{~N}_{3} \mathrm{O}_{2}: \mathrm{C}, 76.07 ; \mathrm{H}, 8.30$. Found: $\mathrm{C}, 75.94 ; \mathrm{H}, 8.22$. ${ }^{1} \mathrm{H}-\mathrm{NMR} \delta \mathrm{ppm} 0.90(\mathrm{t}$, $\left.3 \mathrm{H}, J=7.5 \mathrm{~Hz}, 16 \mathrm{a}-\mathrm{H}_{3}\right) ; 1.02\left(\mathrm{~s}, 3 \mathrm{H}, 18-\mathrm{H}_{3}\right) ; 2.36\left(\mathrm{~s}, 3 \mathrm{H}\right.$, tolyl- $\left.\mathrm{CH}_{3}\right) ; 2.82\left(\mathrm{~m}, 2 \mathrm{H}, 6-\mathrm{H}_{2}\right) ; 3.47$ and 3.73 $\left(2 \times \mathrm{d}, 2 \times 1 \mathrm{H}, J=10.9 \mathrm{~Hz}, 17-\mathrm{H}_{2}\right) ; 5.14\left(\mathrm{~s}, 2 \mathrm{H}, \mathrm{OCH}_{2}\right) ; 5.48\left(\mathrm{~s}, 2 \mathrm{H}, \mathrm{NCH}_{2}\right) ; 6.68(\mathrm{~s}, 1 \mathrm{H}, 4-\mathrm{H}) ; 6.76(\mathrm{~d}, 1 \mathrm{H}$, $J=7.8 \mathrm{~Hz}, 2-\mathrm{H}$ ); 7.17 (overlapping multiplets, $\left.6 \mathrm{H}, 1-\mathrm{H}, \mathrm{C}=\mathrm{CH}, 2^{\prime}, 3^{\prime}, 5^{\prime}, 6^{\prime}-\mathrm{H}\right),{ }^{13} \mathrm{C}-\mathrm{NMR} \delta \mathrm{ppm} 14.6$ (C-16a); 21.1 (tolyl-CH 3 ); 24.9 (C-18); 25.5; 26.6; 27.7; 30.5; 30.9; 35.2; 38.6; 41.7; 43.7; 51.4; $54.2\left(\mathrm{NCH}_{2}\right)$; 62.0 and $64.1\left(\mathrm{OCH}_{2}\right.$ and C-17); $112.4(\mathrm{C}-2) ; 114.3(\mathrm{C}-4) ; 122.4(\mathrm{C}=\mathrm{CH}) ; 126.5(\mathrm{C}-1) ; 128.2\left(2 \mathrm{C}: \mathrm{C}^{\prime} 3^{\prime}, 5^{\prime}\right)$; $129.8\left(2 \mathrm{C}: \mathrm{C}-2^{\prime}, 6^{\prime}\right) ; 131.3\left(\mathrm{C}-4^{\prime}\right) ; 133.4(\mathrm{C}-10) ; 137.9(\mathrm{C}-5) ; 138.8\left(\mathrm{C}-1^{\prime}\right) ; 144.7(\mathrm{C}=\mathrm{CH}) ; 156.0(\mathrm{C}-3)$.

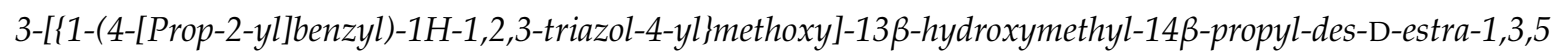
(10)-triene (13c). As described in Section 4.2.4, alkyne $10(326 \mathrm{mg}, 1.00 \mathrm{mmol})$ was reacted with 4-(prop-2-yl)-benzyl azide 11c (175 mg, $1.00 \mathrm{mmol}$ ). Yield: $462 \mathrm{mg}(92 \%) . \mathrm{Mp} 47-49^{\circ} \mathrm{C}, \mathrm{R}_{\mathrm{f}}=0.19$ (B). Anal. Calcd. for $\mathrm{C}_{32} \mathrm{H}_{43} \mathrm{~N}_{3} \mathrm{O}_{2}$ : C, 76.61; H, 8.64. Found: $\mathrm{C}, 76.85 ; \mathrm{H}, 8.53 .{ }^{1} \mathrm{H}-\mathrm{NMR} \delta \mathrm{ppm} 0.91(\mathrm{t}, 3 \mathrm{H}$, $\left.J=6.8 \mathrm{~Hz}, 16 \mathrm{a}-\mathrm{H}_{3}\right) ; 1.02\left(\mathrm{~s}, 3 \mathrm{H}, 18-\mathrm{H}_{3}\right) ; 1.24\left(\mathrm{~d}, 2 \times 3 \mathrm{H}, J=11.4 \mathrm{~Hz}, 2 \times\right.$ prop-2-yl- $\left.\mathrm{CH}_{3}\right) ; 2.82(\mathrm{~m}, 2 \mathrm{H}$, 6- $\left.\mathrm{H}_{2}\right) ; 2.90\left(\mathrm{~m}, 1 \mathrm{H}\right.$, prop-2-yl-CH); 3.47 and $3.73\left(2 \times \mathrm{d}, 2 \times 1 \mathrm{H}, J=10.8 \mathrm{~Hz}, 17-\mathrm{H}_{2}\right) ; 5.15\left(\mathrm{~s}, 2 \mathrm{H}, \mathrm{OCH}_{2}\right)$; $5.49\left(\mathrm{~s}, 2 \mathrm{H}, \mathrm{NCH}_{2}\right) ; 6.68(\mathrm{~d}, 1 \mathrm{H}, J=2.2 \mathrm{~Hz}, 4 \mathrm{H}) ; 6.76(\mathrm{dd}, 1 \mathrm{H}, J=8.6 \mathrm{~Hz}, J=2.2 \mathrm{~Hz}, 2-\mathrm{H}) ; 7.19-7.23$ (overlapping multiplets, $\left.5 \mathrm{H}, 1-\mathrm{H}, 2^{\prime}, 3^{\prime}, 5^{\prime}, 6^{\prime}-\mathrm{H}\right) ; 7.57(\mathrm{~s}, 1 \mathrm{H}, \mathrm{C}=\mathrm{CH}),{ }^{13} \mathrm{C}-\mathrm{NMR} \delta$ ppm 14.5 (C-16a); 23.8 (2C: $\left.\mathrm{CH}\left(\mathrm{CH}_{3}\right)_{2}\right) ; 24.8(\mathrm{C}-18) ; 25.5 ; 26.6 ; 27.7 ; 30.6 ; 31.0 ; 33.8\left(\mathrm{CH}\left(\mathrm{CH}_{3}\right)_{2}\right) ; 35.2 ; 38.6 ; 41.7 ; 43.7 ; 51.4 ; 54.2$ $\left(\mathrm{NCH}_{2}\right) ; 62.1\left(\mathrm{OCH}_{2}\right) ; 64.1(\mathrm{C}-17) ; 112.4(\mathrm{C}-2) ; 114.4(\mathrm{C}-4) ; 122.6(\mathrm{C}=\mathrm{CH}) ; 126.5(\mathrm{C}-1) ; 127.2\left(2 \mathrm{C}: \mathrm{C}^{\prime} 3^{\prime}, 5^{\prime}\right)$; 128.2 (2C: $\left.\mathrm{C}-2^{\prime}, 6^{\prime}\right) ; 131.7\left(\mathrm{C}-1^{\prime}\right) ; 133.4(\mathrm{C}-10) ; 137.9(\mathrm{C}-5) ; 149.7\left(\mathrm{C}-4^{\prime}\right) ; 150.1(\mathrm{C}=\mathrm{CH}) ; 156.0(\mathrm{C}-3)$.

3-[\{1-(4-tert-Butylbenzyl)-1H-1,2,3-triazol-4-yl\}methoxy]-13 $\beta$-hydroxymethyl-14 $\beta$-propyl-des-D-estra-1,3,5 (10)-triene (13d). As described in Section 4.2.4, alkyne $10(326 \mathrm{mg}, 1.00 \mathrm{mmol})$ was reacted with 4-tert-butylbenzyl azide 11d (189 mg, $1.00 \mathrm{mmol})$. Yield: $470 \mathrm{mg}(91 \%) . \mathrm{Mp} 58-60{ }^{\circ} \mathrm{C}, \mathrm{R}_{\mathrm{f}}=0.32(\mathrm{~B})$. Anal. Calcd. for $\mathrm{C}_{33} \mathrm{H}_{45} \mathrm{~N}_{3} \mathrm{O}_{2}$ : C, 76.85; H, 8.79. Found: $\mathrm{C}, 76.72 ; \mathrm{H}, 8.90 .{ }^{1} \mathrm{H} \mathrm{NMR} \delta \mathrm{ppm} 0.91(\mathrm{t}, 3 \mathrm{H}$, $\left.J=7.2 \mathrm{~Hz}, 16 \mathrm{a}-\mathrm{H}_{3}\right) ; 1.02\left(\mathrm{~s}, 3 \mathrm{H}, 18-\mathrm{H}_{3}\right) ; 1.32\left(\mathrm{~s}, 3 \times 3 \mathrm{H}, 3 \times{ }^{\mathrm{t}} \mathrm{Bu}^{\left.-\mathrm{CH}_{3}\right)} ; 2.82\left(\mathrm{~m}, 2 \mathrm{H}, 6-\mathrm{H}_{2}\right) ; 3.47\right.$ and 3.73 $\left(2 \times \mathrm{d}, 2 \times 1 \mathrm{H}, J=10.9 \mathrm{~Hz}, 17-\mathrm{H}_{2}\right) ; 5.16\left(\mathrm{~s}, 2 \mathrm{H}, \mathrm{OCH}_{2}\right) ; 5.49\left(\mathrm{~s}, 2 \mathrm{H}, \mathrm{NCH}_{2}\right) ; 6.67(\mathrm{~d}, 1 \mathrm{H}, J=2.2 \mathrm{~Hz}, 4 \mathrm{H})$; $6.76(\mathrm{dd}, 1 \mathrm{H}, J=8.6 \mathrm{~Hz}, J=2.2 \mathrm{~Hz}, 2-\mathrm{H}) ; 7.18(\mathrm{~d}, 1 \mathrm{H}, J=8.6 \mathrm{~Hz}, 1-\mathrm{H}) ; 7.21\left(\mathrm{~d}, 2 \mathrm{H}, J=8.2 \mathrm{~Hz}, 2^{\prime}, 6^{\prime}-\mathrm{H}\right)$; $7.39\left(\mathrm{~d}, 2 \mathrm{H}, J=8.2 \mathrm{~Hz}, 3^{\prime}, 5^{\prime}-\mathrm{H}\right) ; 7.54(\mathrm{~s}, 1 \mathrm{H}, \mathrm{C}=\mathrm{CH}),{ }^{13} \mathrm{C}-\mathrm{NMR} \delta \mathrm{ppm} 14.5$ (C-16a); 24.9 (C-18); 25.5;

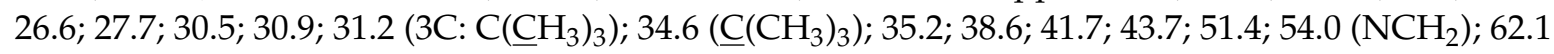
$\left(\mathrm{OCH}_{2}\right) ; 64.1(\mathrm{C}-17) ; 112.4(\mathrm{C}-2) ; 114.3(\mathrm{C}-4) ; 122.6(\mathrm{C}=\mathrm{CH}) ; 126.0\left(2 \mathrm{C}: \mathrm{C}^{\prime} 3^{\prime}, 5^{\prime}\right) ; 126.5(\mathrm{C}-1) ; 127.9(2 \mathrm{C}:$ $\left.\mathrm{C}-2^{\prime}, 6^{\prime}\right) ; 131.3\left(\mathrm{C}-1^{\prime}\right) ; 133.4(\mathrm{C}-10) ; 137.9(\mathrm{C}-5) ; 144.7\left(\mathrm{C}-4^{\prime}\right) ; 151.9$ ( $\left.\mathrm{C}=\mathrm{CH}\right) ; 156.0(\mathrm{C}-3)$.

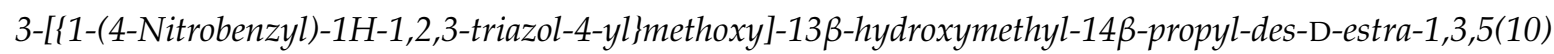
-triene (13e). As described in Section 4.2.4, alkyne $10(326 \mathrm{mg}, 1.00 \mathrm{mmol})$ was reacted with 4-nitrobenzyl azide 11e (178 mg, $1.00 \mathrm{mmol})$. Yield: $475 \mathrm{mg}, 94 \%)$. Mp 50-52 ${ }^{\circ} \mathrm{C}, \mathrm{R}_{\mathrm{f}}=0.12$ (B). Anal. 
Calcd. for $\mathrm{C}_{29} \mathrm{H}_{36} \mathrm{~N}_{4} \mathrm{O}_{4}$ : C, 69.02; H, 7.19. Found: $\mathrm{C}, 69.21 ; \mathrm{H}, 7.05 .{ }^{1} \mathrm{H}-\mathrm{NMR} \delta \mathrm{ppm} 0.91(\mathrm{t}, 3 \mathrm{H}$, $\left.J=6.9 \mathrm{~Hz}, 16 \mathrm{a}-\mathrm{H}_{3}\right) ; 1.02\left(\mathrm{~s}, 3 \mathrm{H}, 18-\mathrm{H}_{3}\right) ; 2.82\left(\mathrm{~m}, 2 \mathrm{H}, 6-\mathrm{H}_{2}\right) ; 3.47$ and $3.73(2 \times \mathrm{d}, 2 \times 1 \mathrm{H}, J=10.9 \mathrm{~Hz}$, $\left.17-\mathrm{H}_{2}\right) ; 5.19\left(\mathrm{~s}, 2 \mathrm{H}, \mathrm{OCH}_{2}\right) ; 5.65\left(\mathrm{~s}, 2 \mathrm{H}, \mathrm{NCH}_{2}\right) ; 6.68(\mathrm{~s}, 1 \mathrm{H}, 4-\mathrm{H}) ; 6.76(\mathrm{~d}, 1 \mathrm{H}, J=8.6 \mathrm{~Hz}, 2-\mathrm{H}) ; 7.20(\mathrm{~d}$, $1 \mathrm{H}, J=8.6 \mathrm{~Hz}, 1-\mathrm{H}) ; 7.40\left(\mathrm{~d}, 2 \mathrm{H}, J=8.3 \mathrm{~Hz}, 2^{\prime}, 6^{\prime}-\mathrm{H}\right) ; 7.64(\mathrm{~s}, 1 \mathrm{H}, \mathrm{C}=\mathrm{CH}) ; 8.23\left(\mathrm{~d}, 2 \mathrm{H}, J=8.5 \mathrm{~Hz}, 3^{\prime}, 5^{\prime}-\mathrm{H}\right)$, ${ }^{13} \mathrm{C}-\mathrm{NMR} \delta$ ppm 14.5 (C-16a); 24.9 (C-18); 25.5; 26.6; 27.7; 30.6; 31.0; 35.2; 38.6; 41.7; 43.7; 51.4; 53.3 $\left(\mathrm{NCH}_{2}\right) ; 62.0\left(\mathrm{OCH}_{2}\right) ; 64.1(\mathrm{C}-17) ; 112.3(\mathrm{C}-2) ; 114.4(\mathrm{C}-4) ; 124.3\left(2 \mathrm{C}: \mathrm{C}-3^{\prime}, 5^{\prime}\right) ; 124.8(\mathrm{C}=\underline{\mathrm{CH}}) ; 126.6(\mathrm{C}-1)$; 128.6 (2C: $\left.\mathrm{C}-2^{\prime}, 6^{\prime}\right) ; 133.6$ (C-10); $138.0(\mathrm{C}-5) ; 141.4\left(\mathrm{C}-1^{\prime}\right) ; 144.0(\mathrm{C}=\mathrm{CH}) ; 144.8\left(\mathrm{C}-4^{\prime}\right) ; 155.9(\mathrm{C}-3)$.

\subsection{Determination of Antiproliferative Activities}

The antiproliferative properties of the prepared triazoles $\mathbf{1 2 a}-\mathbf{e}$ or $\mathbf{1 3 a}-\mathbf{e}$ and compounds $\mathbf{1 , 6} \mathbf{6} \mathbf{- 1 0}$ were determined on a panel of human adherent gynecological cancer cell lines. MCF-7, MDA-MB-231, MDA-MB-361 and T47D were isolated from breast cancers differing in biochemical background, while HeLa, $\mathrm{SiHa}$ and C33A cells were from cervical cancers of various pathological histories, and A2780 cells were isolated from ovarian cancer. Non-cancerous human fibroblast cells (MRC-5) was additionally used to assess the cancer selectivity of the most effective compound. All cell lines were purchased from European Collection of Cell Cultures (ECCAC, Salisbury, UK) except for SiHa and C33A, which were obtained from LGC Standards GmbH (Wesel, Germany). Cells were cultivated in minimal essential medium supplemented with $10 \%$ fetal bovine serum, $1 \%$ non-essential amino acids and an antibiotic-antimycotic mixture. All media and supplements were obtained from Lonza Group Ltd., (Basel, Switzerland). Near-confluent cancer cells were seeded onto a 96-well microplate (5000 cells/well except for C33A and MDA-MB-361, which were seeded at 10,000/well) and, after overnight standing, $200 \mu \mathrm{L}$ new medium, containing the tested compounds at 10 and $30 \mu \mathrm{M}$, was added. After incubation for $72 \mathrm{~h}$ at $37^{\circ} \mathrm{C}$ in humidified air containing $5 \% \mathrm{CO}_{2}$, the living cells were assayed by the addition of $20 \mu \mathrm{L}$ of $5 \mathrm{mg} / \mathrm{ml}$ 3-(4,5-dimethylthiazol-2-yl)-2,5-diphenyltetrazolium bromide (MTT) solution. MTT was converted by intact mitochondrial reductase and precipitated as purple crystals during a 4-h contact period. The medium was next removed and the precipitated formazan crystals were dissolved in $100 \mu \mathrm{L}$ of DMSO during a 60-min period of shaking at $37^{\circ} \mathrm{C}$.

Finally, the reduced MTT was assayed at $545 \mathrm{~nm}$, using a microplate reader; wells with untreated cells served as control [32]. In the case of the most active compounds (i.e., higher than $70 \%$ growth inhibition at $30 \mu \mathrm{M}$ ), the assays were repeated with a set of dilutions, sigmoidal dose-response curves were fitted to the determined data and the $\mathrm{IC}_{50}$ values (the concentration at which the extent of cell proliferation was half that of the untreated control) were calculated by means of GraphPad Prism 4.0 (GraphPad Software, San Diego, CA, USA). All in vitro experiments were carried out on two microplates with at least five parallel wells. Stock solutions of the tested substances $(10 \mathrm{mM})$ were prepared in DMSO. The highest DMSO content of the medium $(0.3 \%)$ did not have any substantial effect on the cell proliferation. Cisplatin (Ebewe Pharma GmbH, Unterach, Austria) was used as positive control.

\section{Conclusions}

Novel antiproliferative triazolyl D-secoestrone derivatives were synthesized by introducing the triazolylmethyl linker between the 3-OH and the benzyl or $p$-substituted benzyl protecting group. The "clicking" of benzyl azides to the 3-propargyl-D-secoestrones led to potent antiproliferative compounds. The synthesized derivatives differed at two sites of the molecules: in the orientation of the angular methyl function and in the nature of the substituent present on the 3-OH group. It can be stated that both variables substantially influenced the antiproliferative behavior. The 3-OH derivatives displayed the lowest growth-inhibitory action. Etherification of the phenolic $\mathrm{OH}$ group improved the cytostatic properties moderately, but the incorporation of the triazolylmethyl linker between the protecting group and the 3-O nevertheless increased the inhibitory values of the compounds substantially. 13 $\beta$-Methyl derivatives proved to be more potent than their $13 \alpha$ counterparts overall. As concerns the $p$-substituent on the $N$-benzyl ring, neither the presence of the electron-withdrawing nor that of the electron-donating group appeared to be advantageous, in contrast 
with the unsubstituted derivative. It can be concluded that the combination of the $13 \beta$-methyl and the 3-(N-benzyltriazolylmethoxy) group on the D-secoestrone scaffold intensifies the antiproliferative potential. These compounds are the most potent cell-growth-inhibitor D-secoestrones reported to date. Antiproliferative potential of $13 \alpha$-D-secoestrone derivatives is a novel finding.

Acknowledgments: The authors are grateful for financial support from the Hungarian Scientific Research Fund (OTKA K113150 and K109293). The work of Noémi Bózsity and Renáta Minorics was supported by a PhD Fellowship of the Talentum Fund of Richter Gedeon Plc. (Budapest) and a János Bolyai Research Scholarship of the Hungarian Academy of Sciences, respectively.

Author Contributions: Johanna Szabó, Nóra Jerkovics and Noémi Bózsity performed the experiments; János Wölfling and Gyula Schneider contributed reagents, materials and analysis tools; Erzsébet Mernyák, Renáta Minorics and István Zupkó conceived and designed the experiments; Erzsébet Mernyák and Renáta Minorics and István Zupkó analyzed the data; Erzsébet Mernyák and István Zupkó wrote the paper.

Conflicts of Interest: The authors declare no conflict of interest.

\section{References}

1. Newman, D.J.; Cragg, G.M. Natural products, derivatives and mimics as antitumor agents. J. Nat. Prod. 2011, 75, 311-335. [CrossRef] [PubMed]

2. Saha, S.K.; Khuda-Bukhsh, A.R. Molecular approaches towards development of purified natural products and their structurally known derivatives as efficient anti-cancer drugs: Current trends. Eur. J. Pharm. 2013, 714, 239-248. [CrossRef] [PubMed]

3. Gupta, A.; Kumar, S.B.; Negi, A.S. Current status on development of steroids as anticancer agents. J. Steroid Biochem. Mol. Biol. 2013, 137, 242-270. [CrossRef] [PubMed]

4. Numazawa, M.; Ando, M.; Watari, Y.; Tominaga, T.; Hayata, Y.; Yoshimura, A. Structure-activity relationships of 2-, 4-, or 6-substituted estrogens as aromatase inhibitors. J. Steroid Biochem. Mol. Biol. 2005, 96, 51-58. [CrossRef] [PubMed]

5. Schönecker, B.; Lange, C.; Kötteritzsch, M.; Günther, W.; Weston, J.; Anders, E.; Görls, H. Conformational design for $13 \alpha$-steroids. J. Org. Chem. 2000, 65, 5487-5497. [CrossRef] [PubMed]

6. Ayan, D.; Roy, J.; Maltais, R.; Poirier, D. Impact of estradiol structural modifications (18-methyl and/or 17-hydroxy inversion of configuration) on the in vitro and in vivo estrogenic activity. J. Steroid Biochem. Mol. Biol. 2011, 127, 324-330. [CrossRef] [PubMed]

7. Penov Gasi, K.M.; Miljkovic, D.A.; Medic Mijacevic, L.D.; Djurendic, E.A.; Stojanovic, S.Z.; Sakac, M.N.; Djurendic, M.D.; Stankovic, S.M.; Lazar, D.; Andric, S.; et al. Synthesis, X-ray crystal structure and biological activity of 16-amino-17-substituted-D-homo steroid derivatives. Steroids 2003, 68, 667-676. [CrossRef]

8. Jovanovic-Santa, S.; Petrovic, J.; Andric, S.; Kovacevic, R.; Durendic, E.; Sakac, M.; Lazar, D.; Stankovic, S. Synthesis, structure, and screening of estrogenic and antiestrogenic activity of new 3,17-substituted16,17-seco-estratriene derivatives. Bioorg. Chem. 2003, 1, 475-484. [CrossRef]

9. Nikolic, A.R.; Petri, E.T.; Klisuric, O.R.; Celic, A.S.; Jakimov, D.S.; Djurendic, E.A.; Penov Gasi, K.M.; Sakac, M.N. Synthesis and anticancer cell potential of steroidal 16,17-seco-16,17a-dinitriles: Identification of a selective inhibitor of hormone-independent breast cancer cells. Bioorg. Med. Chem. 2015, 23, 703-711. [CrossRef] [PubMed]

10. Mernyak, E.; Szabo, J.; Huber, J.; Schneider, G.; Minorics, R.; Bozsity, N.; Zupko, I.; Varga, M.; Bikadi, Z.; Hazai, E.; et al. Synthesis and antiproliferative effects of D-homo- and D-secoestrones. Steroids 2014, 87, 128-136. [CrossRef] [PubMed]

11. Mernyak, E.; Fiser, G.; Szabo, J.; Bodnar, B.; Schneider, G.; Kovacs, I.; Ocsovszki, I.; Zupko, I.; Wölfling, J. Synthesis and in vitro antiproliferative evaluation of D-secooxime derivatives of $13 \beta$ - and $13 \alpha$-estrone. Steroids 2014, 89, 47-55. [CrossRef] [PubMed]

12. Liang, L.; Astruc, D. The copper(I)-catalyzed alkyne-azide cycloaddition (CuAAC) "click" reaction and its applications. An overview. Coord. Chem. Rev. 2011, 255, 2933-2945. [CrossRef]

13. Pedersen, D.S.; Abell, A. 1,2,3-Triazoles in peptidomimetic chemistry. Eur. J. Org. Chem. 2011, 2011, 2399-2411. [CrossRef]

14. Deobald, A.M.; Camargo, L.R.S.; Alves, D.; Zukerman-Schpector, J.; Corrêa, A.G.; Paixão, M.W. Click chemistry: an efficient synthesis of heterocycles substituted with steroids, saponins, and digitalis analogues. Synthesis 2011, 24, 4003-4010. 
15. Szabo, J.; Bacsa, I.; Wölfling, J.; Schneider, G.; Zupko, I.; Varga, M.; Herman, B.E.; Kalmar, L.; Szecsi, M.; Mernyak, E. Synthesis and in vitro pharmacological evaluation of N-[(1-benzyl-1,2,3-triazol-4yl)methyl]-carboxamides on D-secoestrone scaffolds. J. Enzyme Inhib. Med. Chem. 2015. [CrossRef]

16. Kadar, Z.; Baji, A.; Zupko, I.; Bartok, T.; Wölfling, J.; Frank, E. Efficient approach to novel $1 \alpha$-triazolyl$5 \alpha$-androstane derivatives as potent antiproliferative agents. Org. Biomol. Chem. 2011, 9, 8051-8057. [CrossRef] [PubMed]

17. Kadar, Z.; Kovacs, D.; Frank, E.; Schneider, G.; Huber, J.; Zupko, I.; Bartok, T.; Wölfling, J. Synthesis and in vitro antiproliferative activity of novel androst-5-ene triazolyl and tetrazolyl derivatives. Molecules 2011, 16, 4786-4806. [CrossRef] [PubMed]

18. Frank, E.; Molnar, J.; Zupko, I.; Kadar, Z.; Wölfling, J. Synthesis of novel steroidal $17 \alpha$-triazolyl-derivatives via $\mathrm{Cu}(\mathrm{I})$-catalyzed azide-alkyne cycloaddition, and an evaluation of their cytotoxic activity in vitro. J. Steroids 2011, 76, 1141-1148. [CrossRef] [PubMed]

19. Kadar, Z.; Frank, E.; Schneider, G.; Molnar, J.; Zupko, I.; Koti, J.; Schönecker, B.; Wölfling, J. Efficient synthesis of novel A-ring-substituted 1,2,3-triazolylcholestane derivatives via catalytic azide-alkyne cycloaddition. Arkivoc 2012, 3, 279-296.

20. Kadar, Z.; Molnar, J.; Schneider, G.; Zupko, I.; Frank, E. A facile click approach to novel 15 $\beta$-triazolyl$5 \alpha$-androstane derivatives, and an evaluation of their antiproliferative activities in vitro. Bioorg. Med. Chem. 2012, 20, 1396-1402. [CrossRef] [PubMed]

21. Mernyak, E.; Kovacs, I.; Minorics, R.; Sere, P.; Czegany, D.; Sinka, I.; Wölfling, J.; Schneider, G.; Ujfaludi, Z.; Boros, I.; et al. Synthesis of trans-16-triazolyl-13 $\alpha$-methyl-17-estradiol diastereomers and the effects of structural modifications on their in vitro antiproliferative activities. J. Steroid Biochem. Mol. Biol. 2015, 150, 123-134. [CrossRef] [PubMed]

22. Jurasek, M.; Dzubak, P.; Sedlak, D.; Dvorzakova, H.; Hajduch, M.; Bartunek, P.; Drašar, P. Preparation, preliminary screening of new types of steroid conjugates and their activities on steroid receptors. Steroids 2013, 78, 356-361. [CrossRef] [PubMed]

23. Bózsity, N.; Minorics, R.; Szabó, J.; Mernyák, E.; Schneider, G.; Wölfling, J.; Wang, H.C.; Wu, C.C.; Ocsovszki, I.; Zupkó, I. Mechanism of antiproliferative action of a new D-secoestrone-triazole derivative in cervical cancer cells and its effect on cancer cell motility. J. Steroid Biochem. Mol. Biol.. under review.

24. Doorbar, J.; Quint, W.; Banks, L.; Bravo, I.G.; Stoler, M.; Broker, T.R.; Stanley, M.A. The biology and life-cycle of human papillomaviruses. Vaccine 2012, 30S, F55-F70. [CrossRef] [PubMed]

25. Pater, M.M.; Pater, A. Human papillomavirus types 16 and 18 sequences in carcinoma cell lines of the cervix. Virology 1985, 145, 313-318. [CrossRef]

26. Neve, R.M.; Chin, K.; Fridlyand, J.; Yeh, J.; Baehner, F.L.; Fevr, T.; Clark, L.; Bayani, N.; Coppe, J.P.; Tong, F.; et al. A collection of breast cancer cell lines for the study of functionally distinct cancer subtypes. Cancer Cell 2006, 10, 515-527. [CrossRef] [PubMed]

27. Huber, J.; Wölfling, J.; Schneider, G.; Ocsovszki, I.; Varga, M.; Zupkó, I.; Mernyák, E. Synthesis of antiproliferative $13 \alpha$-D-homoestrones via Lewis acid-promoted one-pot Prins-Ritter reactions of D-secosteroidal $\delta$-alkenyl-aldehydes. Steroids 2015, 102, 76-84. [CrossRef] [PubMed]

28. Pardin, C.; Roy, I.; Lubell, W.D.; Keillor, J.W. Reversible and competitive cinnamoyl triazole inhibitors of tissue transglutaminase. Chem. Biol. Drug Des. 2008, 72, 189-196. [CrossRef] [PubMed]

29. Maycock, C.D.; Santos, J.P.; Duarte, M.F.; Frenandez, M.T.; Costa, M.L. Study of selected benzyl azides by UV photoelectron spectroscopy and mass spectrometry. J. Mol. Struct. 2010, 980, 163-171.

30. Pötzsch, R.; Voit, B. Thermal and photochemical crosslinking of hyperbranched polyphenylene with organic azides. Macromol. Rapid Commun. 2012, 33, 635-639. [CrossRef] [PubMed]

31. Barr, L.; Lincoln, S.F.; Easton, C.J. A cyclodextrin molecular reactor for the regioselective synthesis of 1,5-disubstituted-1,2,3-triazoles. Supramol. Chem. 2005, 17, 547-555. [CrossRef]

32. Mosmann, T. Rapid colorimetric assay for cellular growth and survival: Application to proliferation and cytotoxicity assays. J. Immunol. Methods 1983, 65, 55-63. [CrossRef]

Sample Availability: Samples of the compounds are not available.

(C) 2016 by the authors; licensee MDPI, Basel, Switzerland. This article is an open access article distributed under the terms and conditions of the Creative Commons Attribution (CC-BY) license (http://creativecommons.org/licenses/by/4.0/). 
III. 


\title{
A molecular understanding of D-homoestrone-induced G2/M cell cycle arrest in HeLa human cervical carcinoma cells
}

\author{
Renáta Minorics a , Noémi Bózsity a , Judit Molnár a , János Wölfling ${ }^{\mathrm{b}}$, Erzsébet Mernyák ${ }^{\mathbf{b}}$, \\ Gyula Schneider $^{\mathrm{b}}$, Imre Ocsovszki ${ }^{\mathrm{c}}$, István Zupkó a, * \\ a Department of Pharmacodynamics and Biopharmacy, University of Szeged, Szeged, Hungary \\ ${ }^{b}$ Department of Organic Chemistry, University of Szeged, Szeged, Hungary \\ ${ }^{c}$ Department of Biochemistry, University of Szeged, Szeged, Hungary
}

Received: November 4, 2014; Accepted: March 3, 2015

\begin{abstract}
2-Methoxyestradiol (ME), one of the most widely investigated A-ring-modified metabolites of estrone, exerts significant anticancer activity on numerous cancer cell lines. Its pharmacological actions, including cell cycle arrest, microtubule disruption and pro-apoptotic activity, have already been described in detail. The currently tested D-ring-modified analogue of estrone, D-homoestrone, selectively inhibits cervical cancer cell proliferation and induces a G2/M phase cell cycle blockade, resulting in the development of apoptosis. The question arose of whether the difference in the chemical structures of these analogues can influence the mechanism of anticancer action. The aim of the present study was therefore to elucidate the molecular contributors of intracellular processes induced by D-homoestrone in HeLa cells. Apoptosis triggered by D-homoestrone develops through activation of the intrinsic pathway, as demonstrated by determination of the activities of caspase-8 and -9. It was revealed that o-homoestrone-treated HeLa cells are not able to enter mitosis because the cyclin-dependent kinase 1-cyclin B complex loses its activity, resulting in the decreased inactivation of stathmin and a concomitant disturbance of microtubule formation. However, unlike 2-ME, D-homoestrone does not exert a direct effect on tubulin polymerization. These results led to the conclusion that the D-homoestrone-triggered intracellular processes resulting in a cell cycle arrest and apoptosis in HeLa cells differ from those in the case of 2-ME. This may be regarded as an alternative mechanism of action among steroidal anticancer compounds.
\end{abstract}

Keywords: D-homoestrone $\bullet$ tubulin polymerization $\bullet$ stathmin $\bullet$ loss of function of Cdk1 $\bullet$ cell cycle arrest $\bullet$ HeLa cells $\bullet$ G2/M phase transition $\bullet$ Cdc25B and $\mathrm{C} \bullet$ intrinsic apoptotic pathway

\section{Introduction}

The global burden of cancer is continuing to rise, largely because of the ageing and growth of the world's population and the increasing adoption of cancer-causing behaviour, such as smoking and physical inactivity, within economically developing countries. Cancer is the second leading cause of death both worldwide and in economically developed countries [1]. Among women, all types of tumours that affect the reproductive organs (breast, uterus, cervix and ovaries) are to be found in the list of the 10 most frequently diagnosed cancers [2]. Cervical cancer is the second most commonly diagnosed cancer, affecting the reproductive system in females throughout the world. It accounted for some $8 \%$ of the total new cancer cases and $7.5 \%$ of

*Correspondence to: István ZUPKÓ, Ph.D.

E-mail: zupko@pharm.u-szeged.hu the total cancer deaths among women in 2012 [3]. Among the economically developed countries, it demonstrates the highest incidence rates in Central and Eastern Europe.

Since 1977, when zur Hausen published his results, it has been known that human papillomavirus (HPV) infection is a fundamental causative factor of cervical cancer [4]. Despite the introduction of effective vaccination against this infection, it has emerged that it does not have any therapeutic effect against already-established infections or in asymptomatic carriers [5]. The therapeutic interventions include radical surgery, brachytherapy and in most cases platinum-based chemotherapy or a combination of these [6]. As concerns the therapeutic difficulties involved in the treatment regimens, adverse effects including haematological and gastrointestinal toxicities or the lack of a significant improvement in survival rate have been reported in connection with cisplatin, in spite of promising drug and/or radiation 
combinations [7]. The need for newer, more potent and better-tolerated drugs for the therapy of this special type of cancer has therefore not declined.

An endogenous metabolite of $17 \beta$-estradiol, 2-methoxyestradiol (2-ME), was earlier one of the most widely investigated steroidal anticancer agents, thanks to its potent antiproliferative activity against numerous cancer cell lines [reviewed in 8], including cervical cancer [9-11]. Concomitantly, various analogues of 2-ME have been synthetized and tested on cancer cell lines [reviewed in 12], and certain Aand/or D-ring-modified 2-ME derivatives have been reported to exhibit the same or even higher antiproliferative activities (determined most frequently on breast cancer cell lines) than those of 2-ME. However, in the vast majority of the cases, the spectrum of investigations focusing on the mechanisms of action of these potent antiproliferative compounds has been limited to the determination of their effects on tubulin polymerization. It has been concluded that the investigated 2ME derivatives, increase tubulin depolymerization directly similarly to 2-ME. Until recently, only one research group had published experimental results relating to the mechanism of antiproliferative action of novel 2-ME analogues in HeLa cells [13]. The three sulphamoylated analogues investigated induce programmed cell death in HeLa cells via the extrinsic and intrinsic apoptotic pathways followed by autophagy. Their action on tubulin polymerization was elucidated through the use of direct, fluorescence-based tubulin polymerization assays and the microscopic analysis of intracellular microtubules. It was revealed that, similarly to 2-ME, the sulphamoylated analogues increase tubulin depolymerization both in a cell-free system and in living cells. These effects were also demonstrated in MDA-MB-231 breast cancer cells treated with the sulphamoylated analogues.

The present test compound, D-homoestrone, is an analogue of 2ME with structural modifications in its A- and D-rings. This compound was earlier reported to exert potent antiproliferative activity in human cervical cancer cells (HeLa), inducing a cell cycle blockade followed by apoptosis, as demonstrated by morphological markers and caspase 3 activation [14]. In consequence of its selective proliferationinhibiting effect and its structural difference relative to the previously investigated 2-ME analogues, the aim of the present study was to establish whether the intracellular events induced by D-homoestrone in HeLa cells are comparable to those in the case of 2-ME or not. Among others, specific, immune reaction-based flow cytometric analysis, analysis of the mRNA and protein expression of factors involved in the G2/M phase transition and in vitro direct tubulin polymerization assays were performed to shed light on this intriguing question.

\section{Materials and methods}

\section{Chemicals}

Normal D-homoestrone (Fig. 1) was synthetized by Wölfling et al. as described previously [15]. All other chemicals and kits, if otherwise not specified, were purchased from Sigma-Aldrich Ltd. (Budapest, Hungary).<smiles>CC12CCC3c4ccc(O)cc4CCC3C1CCCC2=O</smiles><smiles>COc1cc2c(cc1O)CCC1C2CCC2(C)C(O)CCC12</smiles>

Fig. 1 Chemical structures of D-homoestrone (A) and 2-methoxyestradiol (B).

\section{Cell cultures}

The HeLa human cervix epitheloid carcinoma cell line was purchased from ECACC (European Collection of Cell Cultures, Salisbury, UK). HeLa cells were grown in DMEM supplemented with $10 \%$ heat-inactivated foetal calf serum, $1 \%$ non-essential amino acids and $1 \%$ penicillin-streptomycin in a humidified atmosphere containing $5 \% \mathrm{CO}_{2}$ at $37^{\circ} \mathrm{C}$. The medium and supplements were obtained from Life Technologies (Paisley, UK). Cell counts were determined with a Z1 Coulter Particle Counter (Beckman Coulter Hungary Ltd., Budapest, Hungary). Cells in the near-confluent phase of growth were used in all the studies described below.

\section{Antiproliferative (MTT) assay}

The growth-inhibitory effects of D-homoestrone were determined on SiHa (an HPV-16-positive cervical cancer cell line) and C33A (an HPVnegative cervical cancer cell line) cells to demonstrate the selectivity of its antiproliferative effect towards HPV-18-positive cervical cancer cells. Experiments were carried out in the same way as in the previously described investigations on HeLa cells [14]. Briefly, all cell types were seeded into 96 -well plates at a density of 5000 cells/well and incubated with increasing concentrations $(0.1-30 \mu \mathrm{M})$ of $\mathrm{D}$-homoestrone at $37^{\circ} \mathrm{C}$ under cell culturing conditions. After a 72-hrs incubation, cells were treated with $5.0 \mathrm{mg} / \mathrm{ml}$ MTT (3-(4,5-dimethylthiazol-2-yl)-2,5-diphenyltetrazolium bromide) solution for $4 \mathrm{hrs}$, the precipitated formazan crystals were dissolved in dimethyl sulphoxide, and the absorbance was read at $545 \mathrm{~nm}$ with a microplate reader; wells with untreated cells were utilized as controls [16]. Sigmoidal dose-response curves were fitted to the measured points, and the $I_{50}$ values were calculated by means of GraphPad Prism 4 (GraphPad Software, San Diego, CA, USA).

\section{Determination of in situ caspase-8 activity}

To analyse the effects of D-homoestrone on the activity of caspase-8, the enzyme involved in the extrinsic apoptotic pathway, a commercially available colourimetric assay was performed. Briefly, near-confluent HeLa cells were seeded in tissue culture flasks $\left(10^{6}\right.$ and $10^{7}$ cells/flask for untreated control and treated samples, respectively) and grown overnight under standard cell culturing conditions. The cells were then incubated with increasing concentrations $(1.25,2.5$ and $5.0 \mu \mathrm{M})$ of the test compound for 72 hrs. Meanwhile, the medium of the untreated control cells was replaced. After incubation, the cells were counted, centrifuged and washed with PBS. Aliquots containing $10^{7}$ cells were suspended in $100 \mu \mathrm{l}$ of kit lysis buffer and incubated on ice for $20 \mathrm{~min}$. The lysed cells were subsequently centrifuged and the supernatants were used for the mea- 
surement. In accordance with the manufacturer's protocol, $10 \mu \mathrm{l}$ portions of treated and untreated supernatants were incubated with $10 \mu \mathrm{l}$ of acetyl-Ile-Glu-Thr-Asp p-nitroaniline, a selective caspase-8 substrate, in a final volume of $100 \mu \mathrm{l}$ in assay buffer. As a control experiment, $10 \mu \mathrm{l}$ of each sample was incubated with $10 \mu \mathrm{l}$ of caspase-8 substrate and $2.0 \mu \mathrm{l}$ of acetyl-Ile-Glu-Thr-Asp-aldehyde, a selective caspase-8 inhibitor, in a final volume of $100 \mu \mathrm{l}$ in assay buffer. Each sample was prepared in five parallels. A standard solution of caspase-8 was used as positive control in parallel with inhibitor-treated samples. After an overnight incubation at $37^{\circ} \mathrm{C}$, the absorbance of the $p$-nitroaniline released was measured at $405 \mathrm{~nm}$. Comparison of the absorbance of $p$-nitroaniline from the treated sample with that of an untreated control sample allowed determination of the fold increase in caspase-8 activity.

\section{Determination of in situ caspase-9 activity}

To analyse the effects of D-homoestrone on the proteolytic activity of caspase- 9 , the enzyme involved in the intrinsic apoptotic pathway, a commercially available colourimetric assay (Invitrogen, Carlsbad, CA, USA) was performed. The preparation of the cells before cell lysis was identical with the method described for the determination of in situ caspase- 8 activity. Aliquots containing $3 \times 10^{6}$ cells were then suspended in $50 \mu \mathrm{l}$ of kit lysis buffer and incubated on ice for $10 \mathrm{~min}$. The lysed cells were subsequently centrifuged and the supernatants were used for the measurement. In accordance with the manufacturer's protocol, $50 \mu \mathrm{l}$ portions of treated and untreated supernatants were incubated with $5.0 \mu \mathrm{l}$ of Leu-Glu-His-Asp-p-nitroaniline, a selective caspase-9 substrate, in a final volume of $105 \mu \mathrm{l}$ in reaction buffer containing $10 \mathrm{mM}$ dithiothreitol. Each sample was prepared in five parallels. After an overnight incubation at $37^{\circ} \mathrm{C}$, the absorbance of the $p$-nitroaniline released was measured at $405 \mathrm{~nm}$. Comparison of the absorbance of $p$-nitroaniline from the treated sample with that of an untreated control sample allowed determination of the fold increase in caspase- 9 activity.

\section{Analysis of the G2/M phase transition by flow cytometry}

For a quantitative characterization of the action of the test compound on the G2/M phase transition in HeLa cells, immunocytochemical flow cytometric analysis was performed. HeLa cells $\left(10^{5} /\right.$ well) were seeded in 6-well plates and allowed to proliferate for $48 \mathrm{hrs}$. On the 3rd experimental day, the cells were treated with $20 \mu \mathrm{M}$ D-homoestrone for $24 \mathrm{hrs}$, i.e. the concentration and incubation period used in the previously reported cell cycle analysis [14]. With regard to previous results, 2-ME was administered at $5.0 \mu \mathrm{M}$ for 24 hrs to demonstrate its direct effect on the G2/M phase transition [10]. $5.0 \mathrm{nM}$ paclitaxel was applied as a positive control for $20 \mathrm{hrs}$ [17] to demonstrate the adaptability of the experimental method. The medium of the control cells was concomitantly replaced. After incubation, the cells were counted, washed with PBS, centrifuged and resuspended in the $1 \times$ wash buffer of the commercially available flow cytometric kit (Millipore Co., Billerica, MA, USA). Samples were fixed by adding fixation buffer and incubated for $20 \mathrm{~min}$. at $4^{\circ} \mathrm{C}$. After removal of the supernatant by centrifugation, cells were resuspended in ice-cold $1 \times$ permeabilization buffer and incubated for $5 \mathrm{~min}$. at $4^{\circ} \mathrm{C}$. The supernatant was removed by centrifugation and the samples were washed once by adding $1 \times$ assay buffer. The cells were first stained with anti-phospho-histone H3 (Ser10) antibody directly conjugated to Alexa Fluor 488 for $1 \mathrm{hr}$ at $4^{\circ} \mathrm{C}$ in the dark. After an additional washing step with $1 \times$ assay buffer, the cells were incubated with freshly-prepared propidium iodide/RNase solution for $30 \mathrm{~min}$. at room temperature in the dark. Samples were analysed on a Partec CyFlow instrument (Partec GmbH, Münster, Germany). In each analysis, 20,000 events were recorded, and the percentage of the cells in the $\mathrm{M}$ phase was determined by using Flowing Software 2.5 (Cell Imaging Core, Turku Centre for Biotechnology, Turku, Finland). The fraction stained with anti-phospho-histone H3 (Ser10) antibody was regarded as the cell population in the $\mathrm{M}$ phase [18]. Each sample was prepared in three parallels and the experiment was repeated twice.

\section{RT-PCR studies}

The effects of the tested compound on the mRNA expression pattern of cyclin-dependent kinase 1 (Cdk1), together with cyclin B1 and B2, and its regulator factors $\mathrm{Cdc} 25 \mathrm{~B}$ and $\mathrm{Cdc} 25 \mathrm{C}$, which play a crucial role in the transition from the G2 to the M phase of the cell cycle, were determined by RT-PCR in HeLa cells. After a 48-hrs incubation period, the medium containing the various test compounds was discarded and the total RNA was isolated from the cells $\left(5 \times 10^{5}\right)$ through use of the TRIzol Reagent in accordance with the instructions of the manufacturer (Life Technologies) [19]. The pellet was resuspended in $100 \mu$ of DNase- and RNasefree distilled water. The RNA concentrations of the samples were determined from their absorbances at $260 \mathrm{~nm}$. The RNA $(0.5 \mu \mathrm{g})$ was mixed with DNase- and RNase-free distilled water and $20 \mu \mathrm{M}$ oligo(dT)15 (Promega, Madison, WI, USA), in a final reaction volume of $10 \mu \mathrm{l}$, and was incubated at $70^{\circ} \mathrm{C}$ for $5 \mathrm{~min}$. After the mixture had been cooled to $4^{\circ} \mathrm{C}$, $20 \mathrm{U}$ of RNase inhibitor (Fermentas ${ }^{\mathrm{TM}}$, Thermo Fisher Scientific Inc., Waltham, MA, USA), $20 \mathrm{U}$ of MMLV reverse transcriptase (Promega), $200 \mu \mathrm{M}$ dNTP (Life Technologies) in $50 \mathrm{mM}$ Tris- $\mathrm{HCl}$, pH 8.3, $75 \mathrm{mM} \mathrm{KCl}$ and $5 \mathrm{mM} \mathrm{MgCl} 2$ in a final reaction volume of $10 \mu \mathrm{l}$ were added. The mixture was incubated at $37^{\circ} \mathrm{C}$ for $60 \mathrm{~min}$. The PCR was carried out with $5 \mu \mathrm{l}$ of cDNA, $12.5 \mu \mathrm{l}$ of AccuStart GelTrack PCR SuperMix (Quanta Biosciences Inc., Gaithersburg, MD, USA), $2 \mu \mathrm{l}$ of $20 \mathrm{pM}$ sense and the antisense primer of Cdk1, cyclin B1, cyclin B2, Cdc25B, Cdc25C and $3.5 \mu \mathrm{l}$ of DNase- and RNase-free distilled water. The primer sequences used to amplify Cdk1, cyclin B1 and B2, Cdc25B and Cdc25C were described by Shi et al. [20], Bellanger et al. [21], Takemasa et al. [22] and Lau et al. [23], respectively. Human glyceraldehyde 3-phosphate dehydrogenase primers were used as internal control in all samples (Table S1) [24]. The PCR was performed with an ESCO SWIFT MAXI thermal cycler (Esco Technologies Inc, Philadelphia, PA, USA) and the products were separated on $2 \%$ agarose gels, stained with ethidium bromide and photographed under a UV transilluminator. Each sample was prepared in three parallels and the experiments were repeated twice. Semiquantitative analysis was performed by densitometric scanning of the gel with Kodak IMAGE STATION 2000R (Eastman Kodak Co., Rochester, NY, USA).

\section{Western blotting studies}

To investigate the action of D-homoestrone on the function of CDK1, phosphorylated and total stathmin protein expression was determined by western blot analysis. HeLa cells were harvested in $60-\mathrm{mm}$ dishes at a density of $2 \times 10^{5}$ cells $/ \mathrm{ml}$ and treated with D-homoestrone for $48 \mathrm{hrs}$. Whole-cell extracts were prepared by washing the cells with PBS and suspending them in lysis buffer ( $50 \mathrm{mM}$ Tris, $5 \mathrm{mM}$ EDTA, $150 \mathrm{mM} \mathrm{NaCl}$, $1 \%$ NP-40, $0.5 \%$ deoxycholic acid, $1 \mathrm{mM}$ sodium orthovanadate, $100 \mu \mathrm{g} / \mathrm{ml}$ 
phenylmethanesulfonylfluoride (PMSF) and protease inhibitors) [25]. $10 \mu \mathrm{g}$ of protein per well was subjected to electrophoresis on $4-12 \% \mathrm{Nu}-$ PAGE Bis-Tris Gel in XCell SureLock Mini-Cell Units (Invitrogen). Proteins were transferred from gels to nitrocellulose membranes though use of the iBlot Gel Transfer System (Invitrogen). Antibody binding was detected with the WesternBreeze Chemiluminescent Western blot immunodetection kit (Invitrogen). The blots were incubated on a shaker with stathmin (0p18: rabbit polyclonal antibody raised against amino acids 1-149 representing full-length human protein), phosphorylated stathmin (p-0p18: rabbit polyclonal antibody raised against a short amino acid sequence containing phosphorylated Ser25 of human protein) and $\beta$-actin polyclonal antibody (Santa Cruz Biotechnology, Santa Cruz, CA, USA) 1:200 in the blocking buffer. Each sample was prepared in three parallels and the experiments were repeated twice. Semiquantitative analysis was performed by densitometric scanning of the blot with the Kodak IMAGE STATION 2000R (Eastman Kodak Co.).

\section{Tubulin polymerization assay}

The direct effect of D-homoestrone on tubulin polymerization was tested with the Tubulin Polymerization Assay Kit (Cytoskeleton Inc., Denver, CO, USA) according to the manufacturer's recommendations. Briefly, $10 \mu \mathrm{l}$ of 250 or $500 \mu \mathrm{M}$ test compound solution was subjected to a pre-warmed $\left(37^{\circ} \mathrm{C}\right)$, UV-transparent microplate; $10 \mu \mathrm{l}$ of $10 \mu \mathrm{M}$ paclitaxel and $10 \mu \mathrm{l}$ of general tubulin buffer served as positive and untreated control, respectively. $100 \mu \mathrm{l}$ of $3.0 \mathrm{mg} / \mathrm{ml}$ tubulin in $80 \mathrm{mM}$ PIPES pH 6.9, $2 \mathrm{mM} \mathrm{MgCl}$, $0.5 \mathrm{mM}$ ethylene glycol tetraacetic acid (EGTA), $1 \mathrm{mM}$ guanosine triphosphate (GTP), $10.2 \%$ glycerol was added to each sample, and the microplate was immediately placed into a pre-warmed $\left(37^{\circ} \mathrm{C}\right)$ UVspectrophotometer (SpectoStarNano, BMG Labtech, Ortenberg, Germany) to start the recording of the reaction. A 60-min. kinetic measurement protocol was applied for determination of the absorbance of the reaction solutions at 1-min. intervals at $340 \mathrm{~nm}$. For evaluation of the experimental data, a tubulin polymerization curve was created by plotting optical density against time, and the maximum reaction rate $\left(\mathrm{V}_{\max } ; \Delta\right.$ absorbance/ min.) was calculated. The differences between the absorbances determined at two consecutive measuring timepoints were calculated, and the highest difference was taken as the $\mathrm{V}_{\max }$ value of the tested compound in the tubulin polymerization reaction. Each sample was prepared in two parallels and the measurements were repeated twice.

\section{Statistical analysis}

For statistical evaluation, the experimental data were in all cases analysed by one-way anova with the Neumann-Keuls post test, using GraphPad Prism version 4.01 for Windows (GraphPad Software, San Diego, CA, USA).

\section{Results}

\section{Selective antiproliferative effect of D-homoestrone on HeLa cells}

The proliferation-inhibiting effect of D-homoestrone was demonstrated not only on the HeLa (HPV-18-positive) cervical cancer cell line [14], but also on two other cervical cancer cell lines: SiHa (HPV16-positive) and C33A (HPV-negative). D-Homoestrone did not give rise to effective inhibition of the proliferation of either $\mathrm{SiHa}$ nor C33A cells. The calculated $I_{50}$ values were from three separate experiments $30.7 \pm 0.4 \mu \mathrm{M}$ for SiHa and $32.4 \pm 6.3 \mu \mathrm{M}$ for C33A cells. The calculated $\mathrm{IC}_{50}$ value of $\mathrm{D}$-homoestrone on HeLa cells was previously reported to be $5.5 \mu \mathrm{M}[14]$.

\section{Involvement of the intrinsic apoptotic pathway in programmed cell death induced by D-homoestrone}

To obtain novel and conclusive information about the mechanism of action of apoptosis induction triggered by $\mathrm{D}$-homoestrone, the activities of caspase- 8 and -9 on HeLa cells were determined after exposure to $1.25,2.5$ or $5.0 \mu \mathrm{M}$ of the test compound for $72 \mathrm{hrs}$. DHomoestrone induced a concentration-dependent and significant increase in in situ caspase- 9 activity on HeLa cells relative to the untreated control samples, indicating the participation of the intrinsic pathway in the development of apoptotic cell death (Fig. 2A). However, no significant alteration in caspase-8 activity was detected in the D-homoestrone-treated HeLa cells as compared with the untreated control samples (Fig. 2B).

\section{D-Homoestrone blocks the cell cycle in the G2 phase}

D-Homoestrone has been revealed by flow cytometric analysis to increase the ratio of cells in the G2/M phase significantly [14]. To establish its exact mechanism of action, immunocytochemical flow cytometric analysis was performed. The test compound significantly decreased the ratio of phosphorylated histone $\mathrm{H} 3$ protein relative to the untreated control HeLa cells (Fig. 3), indicating the reduction of the cells in the M phase. Paclitaxel, a widely known mitotic blocking agent [26], was used as positive control. It increased the ratio of phosphorylated histone $\mathrm{H} 3$ protein significantly as compared with the untreated control HeLa cells (Fig. 3). Moreover, after the treatment of HeLa cells with 2-ME for 24 hrs, the proportion of phosphorylated histone $\mathrm{H} 3$ protein was also significantly increased relative to the untreated control cells (Fig. 3).

\section{Inhibition of regulatory proteins of the G2/M phase transition at the mRNA level}

The G2/M transition is known to be a rigorously regulated process during the cell cycle [27]. If the function of the regulatory pathway is affected, cells may not enter the M phase and accumulate in the G2 phase. Although the mRNA expression of the executioner enzyme (Cdk1) demonstrated a non-significant alteration in HeLa cells incubated with D-homoestrone for $48 \mathrm{hrs}$, those of the activating part of the Cdk1-cyclin B complex and its direct upstream regulatory factors 


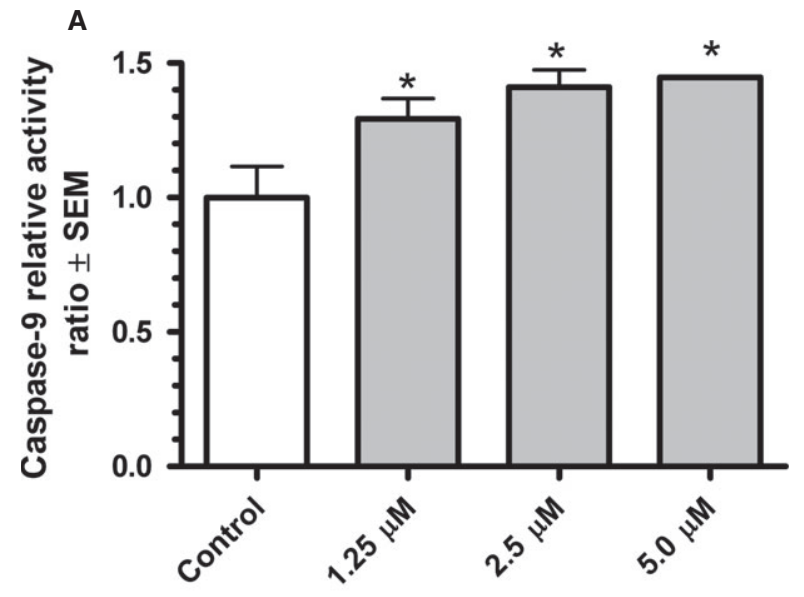

Concentration of D-homoestrone

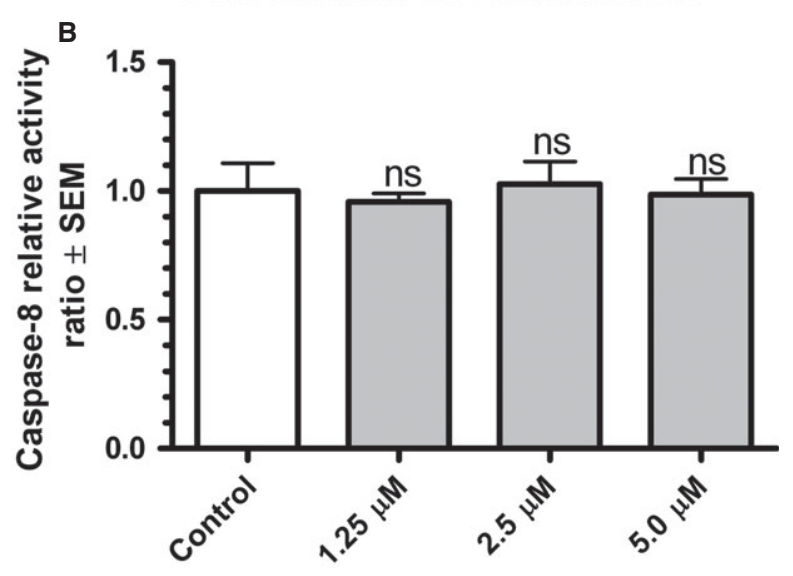

Concentration of D-homoestrone

Fig. 2 In situ measurement of caspase-9 (A) and -8 (B) activities in HeLa cells after treatment with $\mathrm{D}$-homoestrone for $72 \mathrm{hrs}$. The activities of caspase- 9 and -8 in D-homoestrone-treated samples are expressed as ratios relative to the activities of caspase- 9 or -8 in the control (untreated) samples. Data are means $\pm \mathrm{SEM}, n=5$. ns indicates $P>0.05$, and * indicates $P<0.05$ as compared with the untreated control samples.

(e.g. Cdc25B and Cdc25C) were significantly reduced relative to the untreated control cells. However, the mRNA expression of cyclin B2 and $\mathrm{Cdc} 25 \mathrm{C}$ was reduced significantly in the presence of $10 \mu \mathrm{M}$ D-homoestrone alone (Fig. 4).

\section{Functional blockade of the Cdk1-cyclin B complex}

In response to a 48-hrs incubation with D-homoestrone, the protein expression of phospho-stathmin, a microtubule destabilizing protein phosphorylated and therefore inactivated by Cdk1, significantly decreased in comparison with the untreated control cells (Fig. 5A).

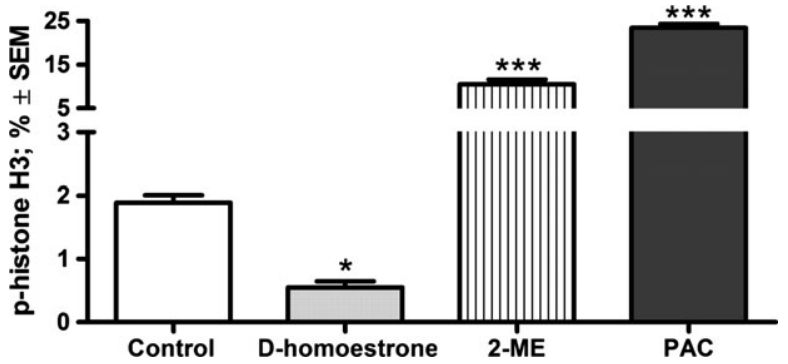

Fig. 3 Effects of $20 \mu \mathrm{M}$ D-homoestrone and $5.0 \mu \mathrm{M}$ 2-ME on the expression of $\mathrm{p}$-histone $\mathrm{H} 3$ protein in HeLa cells after incubation for $24 \mathrm{hrs}$, determined by flow cytometric analysis. Results are mean values \pm SEM of the data on three separate measurements. * indicates $P<0.05$, and $* * *$ indicates $P<0.001$ as compared with the untreated control cells. PAC denotes $5.0 \mathrm{nM}$ paclitaxel and 2-ME denotes $5.0 \mu \mathrm{M}$ 2-methoxyestradiol.

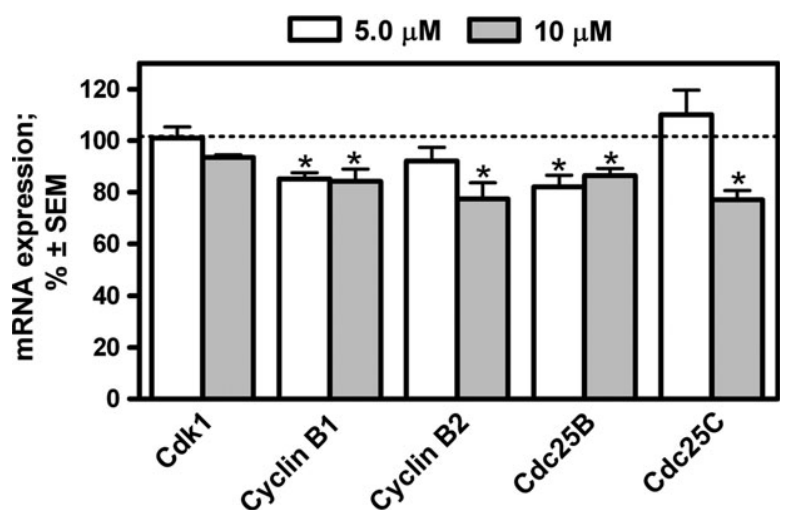

Fig. 4 Effects of $5.0 \mu \mathrm{M}$ (open bars) and $10 \mu \mathrm{M}$ (grey bars) D-homoestrone on the mRNA expression of regulating factors participating in the G2/M transition in HeLa cells after incubation for $48 \mathrm{hrs}$, determined by reverse-transcription PCR. Results are mean values \pm SEM of the data from two separate measurements, $n=6$. * indicates $P<0.05$ as compared with the untreated control samples (dashed line at $100 \%$ ). Nonsignificant changes are not indicated. Cdk1 denotes cyclin-dependent kinase 1.

However, the total protein expression of stathmin did not display a significant alteration as compared with the untreated control cells (Fig. 5B).

\section{D-Homoestrone does not elicit a direct effect on tubulin polymerization}

2-ME and other steroidal antiproliferative agents were earlier reported to affect the tubulin-microtubules system [28, 29], and the effect of D-homoes trone on tubulin polymerization was therefore also determined. D-Homoestrone applied in two different concentrations (250 and $500 \mu \mathrm{M}$ ) did not significantly alter the maximum rate of tubulin 


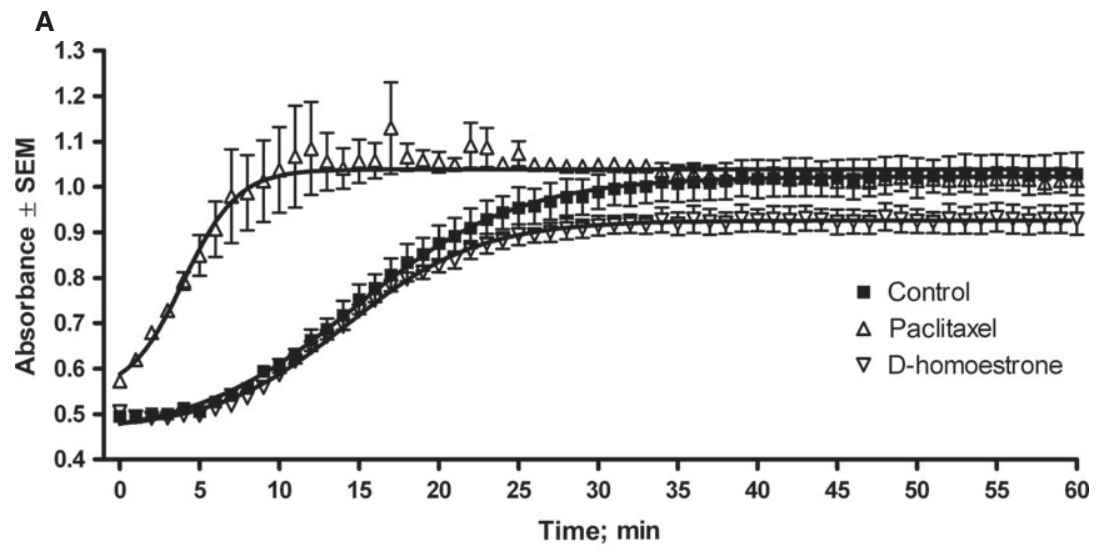

Fig. 6 A representative kinetic curve of the effects of $250 \mu \mathrm{M}$ D-homoestrone and $10 \mu \mathrm{M}$ paclitaxel on tubulin polymerization (A). Direct effects of 250 and $500 \mu \mathrm{M}$ Dhomoestrone and $10 \mu \mathrm{M}$ paclitaxel on the maximum rate of tubulin polymerization determined by an in vitro kinetic assay (B). Results are mean values \pm SEM of the data from two separate measurements, $n=4$. ns indicates $P>0.05$ and $* * *$ indicates $P<0.001$ as compared with the untreated control samples.

polymerization relative to the untreated control samples in an in vitro 1-hr kinetic assay (Fig. 6A). In contrast, the positive control paclitaxel evoked a nearly threefold increase in $V_{\max }$ (Fig. 6B).

\section{Discussion}

There have been numerous investigations of the antiproliferative mechanism of action of 2-ME, the first A-ring-modified estradiol derivative with promising anticancer activity. In view of the chemical similarity of the structures, the cancer cell proliferation-inhibiting mechanism of action of 2-ME might be regarded as a common mode of pharmacological action for all related antiproliferative estradiol derivatives. However, the present paper provides convincing data of an alternative mechanism of action of D-homoestrone, a 2-ME analogue with D-ring expansion. D-Homoestrone was earlier shown to exert a pronounced antiproliferative effect on HeLa cells by inducing apoptosis, preceded by cell cycle blockade at the G2/M phase [14]. Our research into its detailed mechanism of anticancer action has revealed some intriguing differences from that in the case of 2-ME.

Antiproliferative assays have been performed with D-homoestrone on cervical cancer cell lines with various pathological backgrounds (HPV-16-positive SiHa and HPV-negative C33A cell lines) compared to HPV-18-positive HeLa cells. The present and previous results reveal that the anticancer effect of $\mathrm{D}$-homoestrone is selective for
HeLa cells. Although the expressions of the oncoproteins E6 and E7 are detected in both HPV-positive cervical cell lines, which deregulate fundamental cellular events such as apoptosis, cell cycle, DNA repair, senescence and differentiation [reviewed in 30], a slight difference in the apoptotic machinery of these cell lines can be observed. Aréchaga-Ocampo et al. [31] reported different expression profiles of caspases in different HPV-positive cervical cell lines. In HeLa cells (HPV-18+), caspase-3 and -6 displayed low levels of expression, whereas caspase-7, -8 and -9 were expressed at high levels. In contrast, most of the caspases were highly expressed in $\mathrm{SiHa}$ cells (HPV-16+), the exception was caspase-8. This difference might be a possible explanation of the selective susceptibility of HeLa cells to D-homoestrone.

2-Methoxyestradiol has been reported to induce the process of programmed cell death in numerous cancer cell lines, including HeLa(S3) cells, as demonstrated by flow cytometry, fluorescent microscopy and DNA fragmentation data [10]. During the investigation of the mechanism of apoptosis, other research groups reported that 2-ME is able to activate both the intrinsic [11] and the extrinsic [32] apoptotic pathway in HeLa cells. The present results on caspase- 8 and -9 activity allow the conclusion that the previously demonstrated apoptosis-inducing effect of D-homoestrone develops only through the activation of the intrinsic pathway, since the activity of caspase-8 was not altered significantly in HeLa cells after D-homoestrone treatment. 

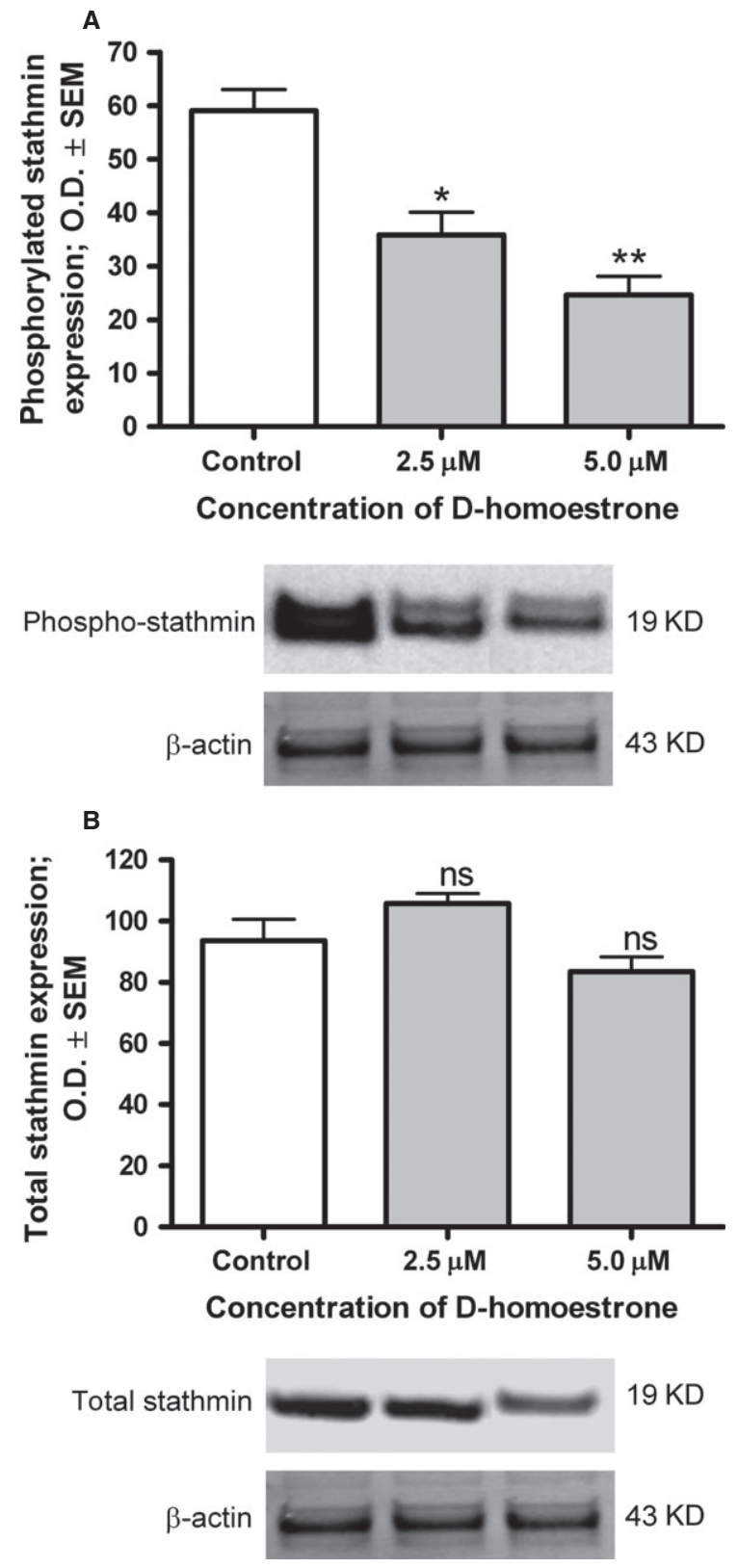

Fig. 5 Effects of 2.5 and $5.0 \mu \mathrm{M}$ D-homoestrone on the expression of phosphorylated (A) and total (B) stathmin protein in HeLa cells after incubation for $48 \mathrm{hrs}$, determined by western blot analysis. Results are mean values \pm SEM of the data from two separate measurements, $n=6$. ns indicates $P>0.05$, * indicates $P<0.05$ and $* *$ indicates $P<0.01$ as compared with the untreated control cells. The $\beta$-actin probe was used as internal control. Panels below are representative membrane pictures.

Earlier cell cycle analyses on various cancer cell lines (including HeLa cells) proved that the proportion of cells in the G2/M phase increased significantly on exposure to 2-ME [10, 33-35]. Similarly,
$5.0 \mu \mathrm{M}$ D-homoestrone evoked a G2/M phase blockade of HeLa cells [14]. After Li et al. [10] had established that the G2/M phase arrest induced by 2-ME was mainly due to the inhibition of mitosis at the metaphase, the question arose of whether the cell cycle blockade induced by D-homoestrone develops in the $\mathrm{G} 2$ or the $\mathrm{M}$ phase. It was earlier reported that an important detectable 'label' on the chromosomes indicates to the cell that duplicated chromosomes are ready for segregation. The amount of this molecule, Ser10 phosphorylated histone $\mathrm{H} 3$, reaches its maximum in the metaphase [36]. Moreover, the presence of phosphorylated histone $\mathrm{H} 3$ is a prerequisite for chromatin condensation, which is regarded as a sign of the onset of the prophase. In our present investigation, the analysis of the presence of phosphorylated histone $\mathrm{H} 3$ on Ser10 revealed that the proportion of o-homoestrone-treated HeLa cells containing this form of the protein was decreased dramatically as compared with the control cells, suggesting that these cells are neither able to arrive at the metaphase of cell cycle nor to demonstrate the initiation of the first step of mitosis. Additionally, 2-ME significantly increased the proportion of phosphorylated histone $\mathrm{H} 3$ as protein compared with that in untreated control samples, indicating an increase in the HeLa cells in the M phase. This result is in good agreement with the recently published data on the cell cycle blockade induced by 2-ME. In morphological assays, 2-MEinduced, abnormal spindle formation was observed in the metaphase in HeLa(S3) cells [10]. Furthermore, Choi and Zhu [35] reported that 2-ME selectively induced a mitotic prometaphase arrest due to its inhibitory effect on microtubule formation, followed by activation of the cyclin B1-CDK1 complex, mediated in part by c-Jun N-terminal kinase (JNK) and mitotic arrest deficient 2 (MAD2) proteins. These experimental findings allow the conclusion that 2-ME exerts a cell cycle blockade at the beginning of mitosis and not in the G2 phase. This difference between the effects of 2ME and D-homoestrone at this step of the cell proliferation process is a crucial one.

The cell cycle is a strictly regulated process which ensures the development of two completely identical and viable cells. It is divided into specific phases according to unique intracellular events, and the transition from one phase to the following one is governed by cascade mechanisms involving various regulatory proteins (e.g. phosphatases, kinases, etc.). The main executor protein of the G2/M phase transition is Cdk1, the functional activity of which is strongly dependent on the expression of cyclin B proteins [27]. During physiological functioning, this complex phosphorylates the proteins responsible for mitotic entry and progression. The effects of 2-ME on Cdk1 expression and activity and on cyclin B1 expression have been widely investigated in numerous cancer cell lines, but not in HeLa cells. The opposite actions of 2-ME on Cdk1 and cyclin B1 expression have been demonstrated, depending on the cell type investigated. Gong et al. [34] observed an inhibitory effect of 2-ME on Cdk1-cyclin B1 activity, followed by a cell cycle arrest at G2/M in RL95-2 human endometrial cells. Two possible molecular mechanisms have been proposed to explain the cell cycle blockade; the direct activation of p53 at Ser15, and the indirect activation of p53 at Ser20 via the induction of checkpoint kinase 1. In both cases, upregulation of the downstream p21 results in a 
decreased activity of Cdk1-cyclin B1. Similarly, a decrease in the expression of Cdk1 and cyclin B1 protein was demonstrated in MCF-7 cells as a result of 2-ME treatment [37]. However, two other research groups reported that 2-ME treatment leads to an increased level of Cdk1 and cyclin B1 protein or only of cyclin B1 protein in MCF-7 cells $[33,35]$. However, it was finally concluded that the observed effect may be connected with mitotic progression and not with mitotic entry. In spite of the limitations of the applied PCR technique, D-homoestrone with a selective antiproliferative effect on HeLa cells proved to decrease the MRNA expressions of cyclin B1 and B2 significantly, but not to affect that of Cdk1, suggesting a reduced functional activity of the complex during the prophase of mitotic entry. The reduced functional activity of the Cdk1-cyclin B complex was confirmed by investigation of the phosphorylated form and the total stathmin expression. Stathmin is one of the several targets of Cdk1; the phosphorylated form of this protein becomes inactive, allowing the formation of microtubules from tubulin heterodimers sequestered earlier by active stathmin, or the inhibition of its microtubule catastrophe-promoting activity when cells enter mitosis (i.e. in the prophase) [38]. Our results revealed a significantly decreased protein expression of phosphorylated (and therefore inactivated) stathmin after a 48-hrs o-homoestrone treatment, whereas the total stathim expression did not exhibit a marked change. This suggests that $\mathrm{D}$-homoestrone induces the expression of active stathmin, resulting in dysregulation of the dynamic instability of the tubulin-microtubule system.

On the other hand, there is an upstream regulatory system which is able to influence the activity of the Cdk1-cyclin B complex. The members of this system include $\mathrm{Cdc} 25 \mathrm{~B}$ and $\mathrm{Cdc} 25 \mathrm{C}$ phosphatases, which activate Cdk1 by dephosphorylating Tyr15 and Thr14 [39]. Moreover, Cdc25A and B are known to be overexpressed in a diverse array of human cancers, suggesting an important role of the Cdc25s in the development of uncontrolled cancer cell division [40]. In our experiments, the Cdc25B mRNA expression was demonstrated to be reduced significantly after a 48 -hr treatment with 5.0 or $10 \mu \mathrm{M}$ D-homoestrone, suggesting decreasing enzymatic activity. However, the change in the mRNA level of Cdc25C, the other phosphatase participating in the control of entry into mitosis, decreased significantly only after treatment with the higher dose of $D$-homoestrone. These findings are consistent with previous results indicating that $\mathrm{Cdc} 25 \mathrm{~B}$ is the initial trigger of mitotic onset and its expression starts slightly earlier than that of Cdc25C [41]. Until recently, the effects of 2-ME on the activity and/or expression of Cdc25 phosphatases had been only poorly investigated. In a cell-free experiment, it inhibited the activity of Cdc25B and C directly [42], and it was also shown to alter the expression profile of the active or inactive form of Cdc25C in different cancer cell lines [35, 43, 44].

Our investigation aimed at an understanding of the antiproliferative mechanism of action of D-homoestrone, additionally demonstrated its direct effect on tubulin polymerization. 2-ME has been reported to inhibit tubulin polymerization in consequence of its interaction with the colchicine-binding site of $\beta$-tubulin [12]. This effect seems to develop during the initial steps of mitosis, which it may allow the conclusion that 2-ME causes the cell cycle arrest at the M phase. In contrast, o-homoestrone did not exhibit any significant action on tubulin polymerization relative to non-treated control samples in an in vitro, cell-free experimental setting. This difference is another significant factor in the comparison of the mechanism of antiproliferative action of $\mathrm{D}$-homoestrone with that of 2-ME.

Overall, our current results suggest that D-homoestrone causes a functional loss of the Cdk1-cyclin B complex, resulting in failure of the G2/M transition in HeLa cells. In contrast with 2-ME, this molecule does not interfere directly with the dynamic equilibrium of tubulin-microtubule system, but because of the inhibited inactivation of stathmin it indirectly disturbs the microtubule formation at the beginning of mitotic entry. Finally, our additional experimental data indicate that $\mathrm{D}$-homoestrone arrests the cell cycle progression immediately before the HeLa cells start to enter mitosis; this is followed by the induction of programmed cell death which, unlike the case with 2-ME, is executed solely via the intrinsic apoptotic pathway. We consider that this alternative mechanism of anticancer action of $\mathrm{D}$-homoestrone in HeLa cells is a promising novel feature in the search for lead compounds against human cervical carcinoma.

\section{Acknowledgements}

This project was supported by the János Bolyai Research Scholarship of the Hungarian Academy of Sciences. The work of N. Bózsity was supported by the Talentum Foundation of Gedeon Richter Ltd. Financial support from the Hungarian Scientific Research Fund (OTKA K-109293 and K-101659) is gratefully acknowledged.

\section{Conflicts of Interest}

The authors declare no competing financial interests or conflicts.

\section{Author contribution}

10 performed the flow cytometric experiments. JM performed the reverse-transcriptase PCR experiments. NB determined caspase-8 and -9 activities and performed tubulin polymerization assay. RM carried out the western blot studies. JW, EM and GS critically analysed results and proof read the manuscript. RM and IZ designed the research and wrote the article.

\section{Supporting information}

Additional Supporting Information may be found in the online version of this article:

Table S1. Primers and PCR conditions of cell cycle regulator genes, the GeneBank access numbers and the length of PCR products. 


\section{References}

1. World Health Organization. Disease and injury regional mortality estimates, 2000 2012. Geneva: World Health Organization; 2012.

2. Jemal A, Bray F, Center MM, et al. Global cancer statistics. CA Cancer J Clin. 2011; 61: 69-90. doi:10.3322/caac.20107.

3. World Health Organization. World Cancer Report 2014. 2014. Chapter 5.12. ISBN 9283204298.

4. Zur Hausen H. Human papillomaviruses and their possible role in squamous cell carcinomas. Berlin, Heidelberg: Springer; 1977.

5. Wheeler CM. Advances in primary and secondary interventions for cervical cancer: human papillomavirus prophylactic vaccines and testing. Nat Clin Pract Oncol. 2007; 4: 224-35.

6. Movva S, Rodriguez L, Arias-Pulido H, et al. Novel chemotherapy approaches for cervical cancer. Cancer. 2009; 115: 3166-80.

7. Suh DH, Kim K, Kim JW. Major clinical research advances in gynaecologic cancer in 2011. J Gynecol Oncol. 2012; 23: 53-64.

8. Mueck A0, Seeger H. 2-Methoxyestradiol Biology and mechanism of action. Steroids. 2010; 75: 625-31.

9. Seegers JC, Aveling ML, van Aswegen CH, et al. The cytotoxic effects of estradiol $17 \beta$, catecholestrogens and methoxyestradiol on dividing MCF-7 and HeLa cells. J Steroid Biochem. 1989; 32: 797-809.

10. Li L, Bu S, Baeckström T, et al. Induction of apoptosis and G2/M arrest by 2-methoxyestradiol in human cervical cancer HeLaS3 cells. Anticancer Res. 2004; 24: 873-80.

11. Joubert A, Martiz C, Joubert F. Influence of prostaglandin $\mathrm{A} 2$ and 2-methoxyestradiol on Bax and Bcl-2 expression levels in cervical carcinoma cells. Biomed Res. 2005; 26: 8790.

12. Peyrat J-F, Brion J-D, Alami M. Synthetic 2methoxyestradiol derivatives: structureactivity relationships. Curr Med Chem. 2012; 19: 4142-56.

13. Visagie M, Theron A, Mqoco T, et al. Sulphamoylated 2-methoxyestradiol analogues induce apoptosis in adenocarcinoma cell lines. PLOS ONE. 2013; 8: e71935. doi:10.1371/journal.pone.0071935.

14. Minorics R, Bózsity N, Wölfling J, et al. Antiproliferative effect of normal and 13-epi-Dhomoestrone and their 3-methyl ethers on human reproductive cancer cell lines. J Steroid Biochem Mol Biol. 2012; 132: 168-75.

15. Wölfling J, Mernyák E, Frank É, et al. Synthesis and receptor-binding examinations of the normal and 13-epi-o-homoestrones and their 3-methyl ethers. Steroids. 2003; 68: 277-88.

16. Mosmann T. Rapid colorimetric assay for cellular growth and survival: application to proliferation and cytotoxicity assays. J Immunol Methods. 1983; 65: 55-63.

17. Jordan MA, Wendell K, Gardiner S, et al. Mitotic block induced in HeLa cells by low concentrations of paclitaxel (taxol) results in abnormal mitotic exit and apoptotic cell death. Cancer Res. 1996; 56: 816-25.

18. Juan G, Traganos F, James WM, et al. Histone $\mathrm{H} 3$ phosphorylation and expression of cyclins A and B1 measured in individual cells during their progression through G2 and mitosis. Cytometry. 1998; 32: 71-7.

19. Chomczynski P, Sacchi N. Single-step method of RNA isolation by acid guanidinium thiocyanate-phenol-chloroform extraction. Anal Biochem. 1987; 162: 156-9.

20. Shi T, Mazumdar T, DeVecchio J, et al. CDNA microarray gene expression profiling of hedgehog signaling pathway inhibition in human colon cancer cells. PLOS ONE. 2010; 5: e13054. doi:10.1371/journal.pone.0013 054.

21. Bellanger S, de Gramont A, Sopczak-Thepot J. Cyclin B2 suppresses mitotic failure and DNA re-replication in human somatic cells knocked down for both cyclins B1 and B2. Oncogene. 2007; 26: 7175-84.

22. Takemasa I, Yamamoto H, Sekimoto M, et al. Overexpression of CDC25B phosphatase as a novel marker of poor prognosis of human colorectal carcinoma. Cancer Res. 2000; 60: 3043-50.

23. Lau W-S, Chen T, Wong Y-S. Allyl isothiocyanate induces G2/M arrest in human colorectal adenocarcinoma SW620 cells through down-regulation of Cdc25B and Cdc25C. Mol Med Rep. 2010; 3: 1023-30.

24. Gao Q, Tan J, Ma P, et al. PKC alpha affects cell cycle progression and proliferation in human RPE cells through the downregulation of p27 kip1. Mol Vis. 2009; 15: 2683-95.

25. Lee CH, Lim H, Moon S, et al. Novel anticancer agent, benzyldihydroxyoctenone, isolated from Streptomyces sp. causes G1 cell cycle arrest and induces apoptosis of HeLa cells. Cancer Sci. 2007; 98: 795-802.

26. Gregory RE, DeLisa AF. Paclitaxel: a new antineoplastic agent for refractory ovarian cancer. Clin Pharm. 1993; 12: 401-15.

27. Morgan DO. The cell cycle. Principles of control. London: New Science Press Ltd.; 2007.
28. Mabjeesh NJ, Escuin D, LaVallee TM, et al. 2ME2 inhibits tumor growth and angiogenesis by disrupting microtubules and dysregulating HIF. Cancer Cell. 2003; 3: 363-75.

29. Newman SP, Foster PA, Ho YT, et al. The therapeutic potential of a series of orally bioavailable anti-angiogenic microtubule disruptors as therapy for hormone-independent prostate and breast cancers. $\mathrm{Br} J$ Cancer. 2007; 97: 1673-82.

30. Tommasino M. The human papillomavirus family and its role in carcinogenesis. Semin Cancer Biol. 2014; 26: 13-21.

31. Aréchaga-Ocampo E, Pereira-Suárez AL, del Moral-Hernández 0 , et al. HPV+ cervical carcinomas and cell lines display altered expression of caspases. Gynecol Oncol. 2008; 108: 10-8.

32. LaVallee TM, Zhan XH, Johnson MS, et al. 2-methoxyestradiol up-regulates death receptor 5 and induces apoptosis through activation of the extrinsic pathway. Cancer Res. 2003; 63: 468-75.

33. Stander BA, Marais S, Vorster CJJ, et al. In vitro effects of 2-methoxyestradiol on morphology, cell cycle progression, cell death and gene expression changes in the tumorigenic MCF-7 breast epithelial cell line. J Steroid Biochem Mol Biol. 2010; 119: 149-60.

34. Gong Q, Liu E, Xin R, et al. 2ME and 2OHE2 exhibit growth inhibitory effects and cell cycle arrest at G2/M in RL95-2 human endometrial cancer cells through activation of p53 and Chk1. Mol Cell Biochem. 2011; 352: 221-30.

35. Choi HJ, Zhu BT. Critical role of cyclin B1/ Cdc2 up-regulation in the induction of mitotic prometaphase arrest in human breast cancer cells treated with 2-methoxyestradiol. Biochim Biophys Acta. 2012; 1823: 130615.

36. Pringent C, Dimitrov S. Phosphorylation of serine 10 in histone H3, what for? J Cell Sci. 2003; 116: 3677-85.

37. Zoubine MN, Weston AP, Johnson DC, et al. 2-methoxyestradiol-induced growth suppression and lethality in estrogenresponsive MCF-7 cells may be mediated by down regulation of $\mathrm{p} 34 \mathrm{cdc2}$ and cyclin $\mathrm{B} 1$ expression. Int J Oncol. 1999; 15: 639-46.

38. Rubin CI, Atweh GF. The role of stathmin in the regulation of the cell cycle. $J$ Cell Biochem. 2004; 93: 242-50.

39. Karlsson-Rosenthal C, Millar JBA. Cdc25: mechanisms of checkpoint inhibition 
and recovery. Trends Cell Biol. 2006; 16: 285-91.

40. Kristjansdottir K, Rudolph J. Cdc25 phosphatases and cancer. Chem Biol. 2004; 11: 1043-51.

41. Lammer C, Wagerer S, Saffrich R, et al. The cdc25B phosphatase is essential for the G2/M phase transition in human cells. J Cell Sci. 1998; 111: 2445-53.
42. Kar S, Wang M, Carr BI. 2-methoxyestradiol inhibits hepatocellular carcinoma cell growth by inhibiting Cdc25 and inducing cell cycle arrest and apoptosis. Cancer Chemother Pharmacol. 2008; 62: 83140.

43. Lee Y-M, Ting C-M, Cheng Y-K, et al. Mechanisms of 2-methoxyestradiol-induced apoptosis and G2/M cell-cycle arrest of nasopharyngeal carcinoma cells. Cancer Lett. 2008; 268: 295-307.

44. Kuo K-L, Lin W-C, Ho I-L, et al. 2-methoxyestradiol induces mitotic arrest, apoptosis, and synergistic cytotoxicity with arsenic trioxide in human urothelial carcinoma cells. PLOS ONE. 2013; 8: e68703. doi:10.1371/journal.pone. 0068703 
IV. 


\title{
Syntheses and antiproliferative effects of D-homo- and D-secoestrones
}

\author{
Erzsébet Mernyák ${ }^{\mathrm{a}, *}$, Johanna Szabó ${ }^{a}$, Ildikó Bacsa ${ }^{\mathrm{a}}$, Judit Huber ${ }^{\mathrm{a}}$, Gyula Schneider ${ }^{\mathrm{a}}$, Renáta Minorics ${ }^{\mathrm{b}}$, \\ Noémi Bózsity ${ }^{\mathrm{b}}$, István Zupkó ${ }^{\mathrm{b}}$, Mónika Varga ${ }^{\mathrm{c}}$, Zsolt Bikádi ${ }^{\mathrm{d}}$, Eszter Hazai ${ }^{\mathrm{d}}$, János Wölfling ${ }^{\mathrm{a}}$ \\ ${ }^{a}$ Department of Organic Chemistry, University of Szeged, Dóm tér 8, H-6720 Szeged, Hungary \\ ${ }^{\mathrm{b}}$ Department of Pharmacodynamics and Biopharmacy, University of Szeged, Eötvös $u$. 6, H-6720 Szeged, Hungary \\ ${ }^{\mathrm{c}}$ Cereal Research Non-Profit LTD, P.O. Box 391, H-6701 Szeged, Hungary \\ ${ }^{d}$ Virtua Drug Ltd, Csalogány u. 4C, H-1015 Budapest, Hungary
}

\section{A R T I C L E I N F O}

\section{Article history:}

Received 27 February 2014

Received in revised form 13 May 2014

Accepted 25 May 2014

Available online 10 June 2014

\section{Keywords:}

Homoestrone

Secoestrone

Antiproliferative effect

MTT assay

Tubulin polymerization

\begin{abstract}
A B S T R A C T
Substituted and/or heterocyclic D-homoestrone derivatives were synthetized via the intramolecular cyclization of a $\delta$-alkenyl-D-secoaldehyde, -D-secoalcohol or -D-secocarboxylic acid of estrone 3-benzyl ether. The D-secoalcohol was modified at three sites in the molecule. The in vitro antiproliferative activities of the new D-homo- and D-secoestrone derivatives were determined on HeLa, MCF-7, A431 and A2780 cells through use of MTT assay. D-Homoalcohols $\mathbf{3}$ and $\mathbf{5}$ displayed cell line-selective cytostatic effects against ovarian and cervical cell lines, respectively. Two D-secoestrones ( 6 and 12c) proved to be effective, with $\mathrm{IC}_{50}$ values comparable with those of the reference agent cisplatin. A selected compound (6) was tested by tubulin polymerization assay and its cancer specificity was additionally determined by using noncancerous human fibroblast cells.
\end{abstract}

(c) 2014 Elsevier Inc. All rights reserved.

\section{Introduction}

Structural modifications of $17 \beta$-estradiol, a proliferation-inducing compound [1], may lead to antiproliferative estrone derivatives [2,3]. Substitution at position 2 and/or D-ring expansion usually reduces the estrogeneity, but enhances the antitumor behavior. Hillisch et al. recently patented antimitotic 2 -substituted D-homoestrone-3-sulfamates [4]. We have found that unsubstituted Dhomoestrone exerts a selective cytostatic effect on HeLa cells $\left(\mathrm{IC}_{50}=5.5 \mu \mathrm{M}\right)$, causing cell cycle arrest in the $\mathrm{G} 2 / \mathrm{M}$ phase and inducing apoptosis, while its 3-methoxy counterpart has no impact on the proliferation of human reproductive cancer cell lines (HeLa, MCF-7 and A2780) [5]. We earlier reported an efficient route for the production of $D$-homoestrone from natural estrone, via the key $\delta$-alkenyl-D-secoestrone-3-benzyl ether 17-carbaldehyde (1) [6]. The latter derivative readily takes part in ring-closure reactions due to the favorable position of its aldehyde and alkenyl moieties. In a preliminary publication, we described that reduction or oxidation of the aldehyde function of the 3-methoxy counterpart of the secoaldehyde leads to a secoalcohol or a secocarboxylic acid, which furnish 16-halomethyl-17-oxa derivatives in haloetherification or halolactonization processes [7]. In the 3-benzyl ether series only

\footnotetext{
* Corresponding author. Tel.: +36 205236959; fax: +36 (62)544200.

E-mail address: bobe@chem.u-szeged.hu (E. Mernyák).
}

iodoetherification of the 3-benzyl-secoalcohol was carried out in order to synthetize cytotoxic estrone-talaromycin hybrids [8]. The resulting diastereomeric mixture of iodomethyl tetrahydropyrans was not separated as the new stereogenic center was lost in the following reaction step. In in vitro cytotoxicity tests of the natural product hybrids on A549 human lung cancer cells, the effective dosage for the most potent derivative proved comparable with that of the well-known anticancer agent cyclophosphamide. In a continuation of our earlier work, we now set out to produce 3-benzyloxy-D-homoestrone derivatives by the elaborated synthetic routes [6,7], extending the haloetherification and halolactonization with selenoetherification and selenolactonization. The 3-benzyl ether protecting group was preferred because of its easy removal. We planned to examine whether the synthetized Dhomoestrones themselves have antiproliferative properties, without the formation of steroid-toxin hybrids. The potential antitumor activities of the newly synthetized D-homo derivatives were tested in vitro on four human reproductive cancer cell lines (HeLa, MCF-7, A2780 and Ishikawa) and one epidermoid tumor cell line (A431). Examination of the influence of the protecting group on $\mathrm{C}-3$ and the substituent on $\mathrm{C}-16$ on the antiproliferative properties was also projected. The tumor specificity of the potent compounds was investigated on noncancerous human foreskin fibroblast cells.

Besides the synthesis and pharmacological testing of the Dhomoestrones, we planned to investigate the precursors of the cyclization reactions and their derivatives. The 3-benzyloxy 
secoalcohol was modified at three sites in the molecule: the alcoholic and/or phenolic hydroxy moiety and the alkenyl side-chain. The hydroxy groups were esterified under solvent-free microwave irradiation. The unsaturated side-chain was saturated under the conditions used for hydrogenolysis of the benzyl ether function.

\section{Experimental}

\subsection{Chemistry}

Melting points (mp) were determined with a Kofler hot-stage apparatus and are uncorrected. Elemental analyses were performed with a Perkin-Elmer CHN analyzer model 2400. Thin-layer chromatography: silica gel $60 \mathrm{~F}_{254}$; layer thickness $0.2 \mathrm{~mm}$ (Merck); eluents: (A) diisopropyl ether, (B) dichloromethane, (C) $70 \%$ dichloromethane/30\% hexane, (D) $2 \%$ ethyl acetate $/ 98 \%$ dichloromethane; detection with iodine or UV (365 nm) after spraying with $5 \%$ phosphomolybdic acid in $50 \%$ aqueous phosphoric acid and heating at $100-120^{\circ} \mathrm{C}$ for $10 \mathrm{~min}$. Flash chromatography: silica gel 60, 40-63 $\mu \mathrm{m}$ (Merck). The reactions under microwave irradiation were carried out with a CEM Corporation focused microwave system, Model Discover SP. ${ }^{1} \mathrm{H}$ NMR spectra were recorded in $\mathrm{CDCl}_{3}$ solution (if not otherwise stated) with a Bruker DRX-500 instrument at $500 \mathrm{MHz}$, with $\mathrm{Me}_{4} \mathrm{Si}$ as internal standard. ${ }^{13} \mathrm{C}$ NMR spectra were recorded with the same instrument at $125 \mathrm{MHz}$ under the same conditions. Full scan mass spectra of the compounds were acquired in the range $50-800 \mathrm{~m} / z$ with an Agilent 500MS Ion trap mass spectrometer equipped with an electrospray ionization source. Analyses were performed in positive ion mode. The spectra were collected by continuous infusion of the steroid solution at $10 \mathrm{ng} / \mu \mathrm{l}$ in $1: 1$ acetonitrile $/ 5 \mathrm{mM}$ ammonium formate $(\mathrm{v} / \mathrm{v} \%)$ at a flow rate of $15 \mu \mathrm{l} / \mathrm{min}$.

\subsubsection{General procedure for the preparation of 17a-hydroxy-D- homoestrone derivatives $\mathbf{3}$ and $\mathbf{5}$}

Compound 2 [6] (372 mg, $1.00 \mathrm{mmol}$ ) or 4 [6] (284 mg, $1.00 \mathrm{mmol})$ was dissolved in methanol $(20 \mathrm{ml})$, and potassium borohydride ( $270 \mathrm{mg}, 5.00 \mathrm{mmol}$ ) was added in small portions in an ice-water bath. The mixture was allowed to stand at room temperature for $3 \mathrm{~h}$, then poured onto ice $(20 \mathrm{~g})$ and acidified with dilute hydrochloric acid to $\mathrm{pH}$ 3. The precipitate that separated out was filtered off, washed until free from acid and dried. The crude product was subjected to column chromatography.

\subsubsection{3-Benzyloxy-17aß-hydroxy-D-homoestra-1,3,5(10),16-tetrae-} ne (3). According to Section 2.1.1, compound 2 (372 mg, $1.00 \mathrm{mmol}$ ) was reacted with potassium borohydride $(270 \mathrm{mg}$, $5.00 \mathrm{mmol}$ ). After work-up, the crude product was subjected to column chromatography with dichloromethane as eluent. 3 was obtained as a white solid (355 mg, 95\%). Mp 202-205 ${ }^{\circ} \mathrm{C}$, $R_{f}=0.40^{\mathrm{A}}$. Anal. Calcd. for $\mathrm{C}_{26} \mathrm{H}_{30} \mathrm{O}_{2}: \mathrm{C}, 83.38 ; \mathrm{H}, 8.07$. Found: $\mathrm{C}$, 83.52; H, 7.95.

${ }^{1} \mathrm{H}$ NMR $\delta$ ppm 0.83(s, 3H, 18- $\left.\mathrm{H}_{3}\right), 2.83\left(\mathrm{~m}, 2 \mathrm{H}, 6-\mathrm{H}_{2}\right), 3.94(\mathrm{~s}, 1 \mathrm{H}$, $17 \mathrm{a}-\mathrm{H}), 5.04\left(\mathrm{~s}, 2 \mathrm{H}, \mathrm{OCH}_{2}\right), 5.52(\mathrm{~m}, 1 \mathrm{H})$ and $5.74(\mathrm{~m}, 1 \mathrm{H}): 16-\mathrm{H}$ and $17-\mathrm{H}, 6.71(\mathrm{~d}, 1 \mathrm{H}, J=2.3 \mathrm{~Hz}, 4-\mathrm{H}), 6.78(\mathrm{dd}, 1 \mathrm{H}, J=8.5 \mathrm{~Hz}, J=2.3 \mathrm{~Hz}$, 2-H), 7.23(d, $1 \mathrm{H}, J=8.5 \mathrm{~Hz}, 1-\mathrm{H}), 7.24\left(\mathrm{~m}, 1 \mathrm{H}, 4^{\prime}-\mathrm{H}\right), 7.34\left(\mathrm{~m}, 2 \mathrm{H}, 3^{\prime}-\right.$ $\mathrm{H}$ and $\left.5^{\prime}-\mathrm{H}\right), 7.42\left(\mathrm{~m}, 2 \mathrm{H}, 2^{\prime}-\mathrm{H}\right.$ and $\left.6^{\prime}-\mathrm{H}\right) .{ }^{13} \mathrm{C}$ NMR $\delta \mathrm{ppm} 11.0(\mathrm{C}-18)$, 26.2(2C), 27.1, 30.1, 37.4(C-13), 37.5, 39.8, 43.0, 43.8, 70.0 $\left(\mathrm{OCH}_{2}\right)$, 78.1(C-17a), 112.4(C-2), 114.5(C-4), 126.4(C-1), 127.4(2C: C-2', $\left.6^{\prime}\right)$, 127.7, 127.8(C-4'), 128.5(2C: C-3', $\left.5^{\prime}\right), 130.1,133.0(C-10), 137.3(C-$ $\left.1^{\prime}\right), 137.9(\mathrm{C}-5), 156.8(\mathrm{C}-3)$. MS m/z (\%): 375 (100), 397 (54), 91 (42).

2.1.1.2. 3,17a $\beta$-Dihydroxy-D-homoestra-1,3,5(10)-triene (5). According to Section 2.1.1, compound 4 (284 $\mathrm{mg}, 1.00 \mathrm{mmol}$ ) was reacted with potassium borohydride $(270 \mathrm{mg}, 5.00 \mathrm{mmol}$ ). After work-up, the crude product was subjected to column chromatography with dichloromethane as eluent. 5 was obtained as a white solid (243 mg, 85\%). Melting point $208-209{ }^{\circ} \mathrm{C}$ [9]: mp 209-210 ${ }^{\circ} \mathrm{C}$. Compound $\mathbf{5}$ is identical with the compound described in [9]. Anal. Calcd. for $\mathrm{C}_{19} \mathrm{H}_{26} \mathrm{O}_{2}$ : C, 79.68; $\mathrm{H}, 9.15$. Found: $\mathrm{C}, 79.92 ; \mathrm{H}, 9.05$.

${ }^{1} \mathrm{H}$ NMR (DMSO-d $\left.\mathrm{d}_{6}\right) \delta \mathrm{ppm} 0.73\left(\mathrm{~s}, 3 \mathrm{H}, 18-\mathrm{H}_{3}\right), 2.67\left(\mathrm{~m}, 2 \mathrm{H}, 6-\mathrm{H}_{2}\right)$, $4.29(\mathrm{~m}, 1 \mathrm{H}, 17 \mathrm{a}-\mathrm{H}), 6.42(\mathrm{~m}, 1 \mathrm{H}, 4-\mathrm{H}), 6.50(\mathrm{~m}, 1 \mathrm{H}, 2-\mathrm{H}), 7.05(\mathrm{~m}, 1 \mathrm{H}$, $1-\mathrm{H}), 8.96(\mathrm{~s}, 1 \mathrm{H}, 3-\mathrm{OH})$.

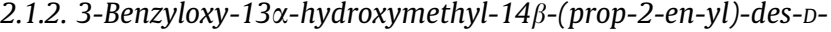 estra-1,3,5(10)-triene (6)}

Compound 1 (374 mg, $1.00 \mathrm{mmol}$ ) was dissolved in a 1:1 mixture of dichloromethane and methanol, and potassium borohydride $(270 \mathrm{mg}, 5.00 \mathrm{mmol}$ ) was added in small portions in an icewater bath. The mixture was allowed to stand at room temperature for $0.5 \mathrm{~h}$, then diluted with water and extracted with dichloromethane. The combined organic phases were washed with water until neutral and dried over sodium sulfate, and the crude product was subjected to column chromatography with dichloromethane as eluent. 6 was obtained as a white solid (327 mg, 87\%). Oil, $R_{f}=0.53^{\mathrm{D}}$. Anal. Calcd. for $\mathrm{C}_{26} \mathrm{H}_{32} \mathrm{O}_{2}: \mathrm{C}, 82.94 ; \mathrm{H}, 8.57$. Found: $\mathrm{C}$, 83.05; $\mathrm{H}, 8.45 .{ }^{1} \mathrm{H}$ NMR $\delta \mathrm{ppm} 0.80\left(\mathrm{~s}, 3 \mathrm{H}, 18-\mathrm{H}_{3}\right), 2.85(\mathrm{~m}, 2 \mathrm{H}, 6-$ $\left.\mathrm{H}_{2}\right), 3.30$ and $3.61\left(2 \times \mathrm{m}, 2 \times 1 \mathrm{H}, 17-\mathrm{H}_{2}\right), 5.03\left(\mathrm{~m}, 2 \mathrm{H}, 16 \mathrm{a}-\mathrm{H}_{2}\right)$, $5.04\left(\mathrm{~s}, 2 \mathrm{H}, \mathrm{OCH}_{2}\right), 5.93(\mathrm{~m}, 1 \mathrm{H}, 16-\mathrm{H}), 6.73(\mathrm{~d}, 1 \mathrm{H}, J=2.3 \mathrm{~Hz}, 4-\mathrm{H})$, $6.79(\mathrm{dd}, 1 \mathrm{H}, J=8.5 \mathrm{~Hz}, J=2.3 \mathrm{~Hz}, 2-\mathrm{H}), 7.22(\mathrm{~d}, 1 \mathrm{H}, J=8.5 \mathrm{~Hz}, 1-$ $\mathrm{H}), 7.32\left(\mathrm{t}, 1 \mathrm{H}, J=7.3 \mathrm{~Hz}, 4^{\prime}-\mathrm{H}\right), 7.38\left(\mathrm{t}, 2 \mathrm{H}, J=7.3 \mathrm{~Hz}, 3^{\prime}-\mathrm{H}\right.$ and $5^{\prime}-$ $\mathrm{H}), 7.43\left(\mathrm{~d}, 2 \mathrm{H}, J=7.3 \mathrm{~Hz}, 2^{\prime}-\mathrm{H}\right.$ and $\left.6^{\prime}-\mathrm{H}\right),{ }^{13} \mathrm{C}$ NMR $\delta \mathrm{ppm} 16.2(\mathrm{C}-$ 18), 26.2, 27.6, 30.4, 32.4, 35.9, 38.9(C-13), 41.2, 43.5, 44.3, 70.0 $\left(\mathrm{OCH}_{2}\right), \quad 71.0(\mathrm{C}-17), \quad 112.4(\mathrm{C}-2), \quad 114.3(\mathrm{C}-16 \mathrm{a}), \quad 114.4(\mathrm{C}-4)$, 126.4(C-1), 127.4(2C: $\left.\quad \mathrm{C}-2^{\prime}, 6^{\prime}\right), \quad 127.8\left(\mathrm{C}-4^{\prime}\right), \quad 128.5\left(2 \mathrm{C}: \quad \mathrm{C}-3^{\prime}, 5^{\prime}\right)$, 133.1(C-10), 137.3(C-1'), 138.0(C-5), 140.5(C-16), 156.8(C-3). MS $m / z$ (\%): 431 (100).

2.1.3. 3-Benzyloxy-14 $\beta$-(prop-2-en-yl)-des-D-estra-1,3,5(10)-trien$13 \alpha$-carboxylic acid (7) and 3-benzyloxy-14 $\beta$-(prop-2-en-yl)-des-Destra-1,3,5(10)-trien-13 $\alpha, 9 \alpha$-carbolactone $(\boldsymbol{8})$

Compound 1 (374 $\mathrm{mg}, 1.00 \mathrm{mmol}$ ) was dissolved in acetone $(3 \mathrm{ml})$, then cooled in an ice-water bath and Jones reagent $(0.4 \mathrm{ml}, 8 \mathrm{~N})$ was added in three portions. The reaction mixture was allowed to stand at room temperature for $4 \mathrm{~h}$, then diluted with water and extracted with diethyl ether. The combined organic phases were washed with water until neutral and dried over sodium sulfate, and the crude product was subjected to column chromatography with dichloromethane as eluent. The first-eluted 8 was obtained as a white solid $(144 \mathrm{mg}, 37 \%)$. Mp $110-118{ }^{\circ} \mathrm{C}$, $R_{f}=0.63^{D}$. Anal. Calcd. For $\mathrm{C}_{26} \mathrm{H}_{28} \mathrm{O}_{3}: \mathrm{C}, 80.38 ; \mathrm{H}, 7.26$. Found: $\mathrm{C}$, $80.45 ; \mathrm{H}, 7.12 .{ }^{1} \mathrm{H}$ NMR $\delta \mathrm{ppm} 1.22\left(\mathrm{~s}, 3 \mathrm{H}, 18-\mathrm{H}_{3}\right), 2.73(\mathrm{~m}, 2 \mathrm{H}, 6-$ $\left.\mathrm{H}_{2}\right), 5.05\left(\mathrm{~s}, 2 \mathrm{H}, \mathrm{OCH}_{2}\right), 5.09-5.16$ (overlapping multiplets, $2 \mathrm{H}$, $\left.16 \mathrm{a}-\mathrm{H}_{2}\right), 5.85(\mathrm{~m}, 1 \mathrm{H}, 16-\mathrm{H}), 6.71(\mathrm{~d}, 1 \mathrm{H}, J=2.3 \mathrm{~Hz}, 4-\mathrm{H}), 6.85(\mathrm{dd}$, $1 \mathrm{H}, J=8.5 \mathrm{~Hz}, J=2.3 \mathrm{~Hz}, 2-\mathrm{H}), 7.26(\mathrm{~d}, 1 \mathrm{H}, J=8.5 \mathrm{~Hz}, 1-\mathrm{H}), 7.34(\mathrm{t}$, $\left.1 \mathrm{H}, J=7.3 \mathrm{~Hz}, 4^{\prime}-\mathrm{H}\right), 7.39\left(\mathrm{t}, 2 \mathrm{H}, J=7.3 \mathrm{~Hz}, 3^{\prime}-\mathrm{H}\right.$ and $\left.5^{\prime}-\mathrm{H}\right), 7.42(\mathrm{~d}$, $2 \mathrm{H}, J=7.3 \mathrm{~Hz}, 2^{\prime}-\mathrm{H}$ and $\left.6^{\prime}-\mathrm{H}\right),{ }^{13} \mathrm{C}$ NMR $\delta$ ppm $18.6(\mathrm{C}-18), 25.3$, $26.8,30.1,31.9,34.5,40.4(\mathrm{C}-13), 44.7,45.2,69.9\left(\mathrm{OCH}_{2}\right), 80.6(\mathrm{C}-$ 9), 113.5(C-2), 114.3(C-4), 117.0(C-16a), 127.4(2C: C-2', $\left.6^{\prime}\right)$, 127.9(C-4'), 128.5(2C: C-3', $\left.5^{\prime}\right), 129.1(C-1), 130.2(C-10), 136.2(C-$ 16), 136.9(C-1'), 139.3(C-5), 158.7(C-3), 178.2(C-17). MS $m / z(\%)$ : 446 (100), 411 (42).

Continued elution yielded 7, which was obtained as a white solid (223 mg, 57\%). Mp $120-122^{\circ} \mathrm{C} . R_{f}=0.32^{\mathrm{D}}$. Anal. Calcd. for $\mathrm{C}_{26} \mathrm{H}_{30} \mathrm{O}_{3}$ : C, 79.97; $\mathrm{H}, 7.74$. Found: $\mathrm{C}, 80.03 ; \mathrm{H}, 7.68 .,{ }^{1} \mathrm{H}$ NMR $\delta$ ppm 1.19(s, 3H, 18- $\left.\mathrm{H}_{3}\right), 2.84\left(\mathrm{~m}, 2 \mathrm{H}, 6-\mathrm{H}_{2}\right), 5.01\left(\mathrm{~m}, 2 \mathrm{H}, 16 \mathrm{a}-\mathrm{H}_{2}\right)$, $5.05\left(\mathrm{~s}, 2 \mathrm{H}, \mathrm{OCH}_{2}\right), 5.88(\mathrm{~m}, 1 \mathrm{H}, 16-\mathrm{H}), 6.73(\mathrm{~d}, 1 \mathrm{H}, J=2.3 \mathrm{~Hz}, 4-\mathrm{H})$, $6.80(\mathrm{dd}, 1 \mathrm{H}, J=8.5 \mathrm{~Hz}, J=2.3 \mathrm{~Hz}, 2-\mathrm{H}), 7.20(\mathrm{~d}, 1 \mathrm{H}, J=8.5 \mathrm{~Hz}$, $1-\mathrm{H}), 7.32\left(\mathrm{t}, 1 \mathrm{H}, J=7.3 \mathrm{~Hz}, 4^{\prime}-\mathrm{H}\right), 7.39\left(\mathrm{t}, 2 \mathrm{H}, J=7.3 \mathrm{~Hz}, 3^{\prime}-\mathrm{H}\right.$ and $\left.5^{\prime}-\mathrm{H}\right), 7.43\left(\mathrm{~d}, 2 \mathrm{H}, J=7.3 \mathrm{~Hz}, 2^{\prime}-\mathrm{H}\right.$ and $\left.66^{\prime}-\mathrm{H}\right),{ }^{13} \mathrm{C}$ NMR $\delta \mathrm{ppm}$ 15.0(C-18), 25.8, 27.1, 28.7, 30.2, 35.7, 37.4, 40.9, 43.0, 45.4, 
47.4(C-13), $\quad 70.0\left(\mathrm{OCH}_{2}\right), \quad 112.5(\mathrm{C}-2), \quad 114.5(\mathrm{C}-4), \quad 115.3(\mathrm{C}-16 \mathrm{a})$, 126.4(C-1), 127.4(2C: $\left.\mathrm{C}-2^{\prime}, 6^{\prime}\right), \quad 127.9\left(\mathrm{C}-4^{\prime}\right), 128.5\left(2 \mathrm{C}: \mathrm{C}-3^{\prime}, 5^{\prime}\right)$, 132.4(C-10), 137.2(C-1'), 137.9(C-5), 138.8(C-16), 156.8(C-3), 184.5(C-17). MS $m / z(\%): 435$ (100).

\subsubsection{3-Benzyloxy-16 $\beta$-bromomethyl-17-oxa-D-homoestra-1,3,5(10)-} triene $(\mathbf{9 a})$

Compound 6 (188 mg, $0.50 \mathrm{mmol})$ was dissolved in dichloromethane $(5 \mathrm{ml})$, then cooled in an ice-salt bath to $-15^{\circ} \mathrm{C}$, and $\mathrm{N}$-bromosuccinimide $(89 \mathrm{mg}, 0.50 \mathrm{mmol}$ ) was added in three portions. The mixture was stirred for $30 \mathrm{~min}$, the solvent was evaporated off and the residue was subjected to column chromatography with $70 \%$ dichloromethane/30\% hexane, yielding 9a as a white solid ( $155 \mathrm{mg}, 68 \%)$. Mp $107-108{ }^{\circ} \mathrm{C}, R_{f}=0.51^{\mathrm{C}}$. Anal. Calcd. for $\mathrm{C}_{26} \mathrm{H}_{31} \mathrm{BrO}_{2}$ : C, 68.57; $\mathrm{H}, 6.86$. Found: $\mathrm{C}, 68.82 ; \mathrm{H}, 6.75 .{ }^{1} \mathrm{H}$ NMR $\delta$ ppm 1.01(s, 3H, 18- $\left.\mathrm{H}_{3}\right), 2.84\left(\mathrm{~m}, 2 \mathrm{H}, 6-\mathrm{H}_{2}\right), 3.17(\mathrm{~m}, 1 \mathrm{H})$ and 3.58(overlapping multiplets, $2 \mathrm{H}): 17-\mathrm{H}_{2}$ and $16-\mathrm{H}, 3.46(\mathrm{~m}$, $\left.2 \mathrm{H}, 16 \mathrm{a}-\mathrm{H}_{2}\right), 5.04\left(\mathrm{~s}, 2 \mathrm{H}, \mathrm{OCH}_{2}\right), 6.73(\mathrm{~d}, 1 \mathrm{H}, J=2.3 \mathrm{~Hz}, 4-\mathrm{H})$, $6.79(\mathrm{dd}, 1 \mathrm{H}, J=8.5 \mathrm{~Hz}, J=2.3 \mathrm{~Hz}, 2-\mathrm{H}), 7.21(\mathrm{~d}, 1 \mathrm{H}, J=8.5 \mathrm{~Hz}$, $1-\mathrm{H}), 7.30\left(\mathrm{t}, 1 \mathrm{H}, J=7.3 \mathrm{~Hz}, 4^{\prime}-\mathrm{H}\right), 7.37\left(\mathrm{t}, 2 \mathrm{H}, J=7.3 \mathrm{~Hz}, 3^{\prime}-\mathrm{H}\right.$ and $\left.5^{\prime}-\mathrm{H}\right), \quad 7.42\left(\mathrm{~d}, 2 \mathrm{H}, J=7.3 \mathrm{~Hz}, 2^{\prime}-\mathrm{H}\right.$ and $\left.6^{\prime}-\mathrm{H}\right),{ }^{13} \mathrm{C}$ NMR $\delta \mathrm{ppm}$ 16.5(C-18), 25.5, 25.7, 28.8, 29.9, 34.0(C-13), 35.1, 36.2, 38.5, 43.7, 47.2, $\quad 69.9\left(\mathrm{OCH}_{2}\right), \quad 77.6(\mathrm{C}-16), \quad 79.9(\mathrm{C}-17), \quad 112.4(\mathrm{C}-2)$, 114.6(C-4), 126.1(C-1), 127.4(2C: C-2',6' $\left.6^{\prime}\right), 127.8\left(\mathrm{C}-4^{\prime}\right), 128.5(2 \mathrm{C}$ : C-3', $\left.5^{\prime}\right), 132.8(\mathrm{C}-10), 137.3\left(\mathrm{C}-1^{\prime}\right), 137.8(\mathrm{C}-5), 156.8(\mathrm{C}-3)$. MS $\mathrm{m} / \mathrm{z}$ (\%): 457 (63), 455 (100), 453 (37).

\subsubsection{3-Benzyloxy-16 $\beta$-iodomethyl-17-oxa-D-homoestra-1,3,5(10)-} triene (9b) and 3-benzyloxy-16 $\alpha$-iodomethyl-17-oxa-D-homoestra1,3,5(10)-triene (10b)

Compound 6 (188 mg, $0.50 \mathrm{mmol})$ was dissolved in diethyl ether $(2 \mathrm{ml})$, and water $(0.7 \mathrm{ml})$, sodium hydrogencarbonate $(84 \mathrm{mg}, 1.00 \mathrm{mmol})$ and iodine $(127 \mathrm{mg}, 0.50 \mathrm{mmol})$ were then added. The mixture was stirred for $1 \mathrm{~h}$ at room temperature, diluted with water and extracted with diethyl ether. The organic phase was separated and washed with a saturated solution of sodium thiosulfate and then with water. The organic phase was dried over sodium sulfate and evaporated, and the residue was subjected to column chromatography with $70 \%$ dichloromethane/ $30 \%$ hexane. 9b eluted first as a white solid (127 mg, 50\%). Mp $105-108{ }^{\circ} \mathrm{C}, R_{f}=0.51^{\mathrm{C}}$. Anal. Calcd. for $\mathrm{C}_{26} \mathrm{H}_{31} \mathrm{IO}_{2}: \mathrm{C}, 62.15 ; \mathrm{H}$, 6.22. Found: $\mathrm{C}, 62.02 ; \mathrm{H}, 6.35 .{ }^{1} \mathrm{H}$ NMR $\delta \mathrm{ppm} 1.01\left(\mathrm{~s}, 3 \mathrm{H}, 18-\mathrm{H}_{3}\right)$, $2.85\left(\mathrm{~m}, 2 \mathrm{H}, 6-\mathrm{H}_{2}\right), 3.18$ and $3.58\left(2 \times \mathrm{m}, 2 \times 1 \mathrm{H}, 17-\mathrm{H}_{2}\right), 3.26-$ 3.33(overlapping multiplets, $3 \mathrm{H}, 16 \mathrm{a}-\mathrm{H}_{2}$ and $\left.16-\mathrm{H}\right), 5.04(\mathrm{~s}, 2 \mathrm{H}$, $\left.\mathrm{OCH}_{2}\right), 6.73(\mathrm{~d}, 1 \mathrm{H}, J=2.3 \mathrm{~Hz}, 4-\mathrm{H}), 6.79(\mathrm{dd}, 1 \mathrm{H}, J=8.5 \mathrm{~Hz}$, $J=2.3 \mathrm{~Hz}, 2-\mathrm{H}), 7.21(\mathrm{~d}, 1 \mathrm{H}, J=8.5 \mathrm{~Hz}, 1-\mathrm{H}), 7.32(\mathrm{t}, 1 \mathrm{H}, J=7.3 \mathrm{~Hz}$, $\left.4^{\prime}-\mathrm{H}\right), 7.38\left(\mathrm{t}, 2 \mathrm{H}, J=7.3 \mathrm{~Hz}, 3^{\prime}-\mathrm{H}\right.$ and $\left.5^{\prime}-\mathrm{H}\right), 7.43(\mathrm{~d}, 2 \mathrm{H}, J=7.3 \mathrm{~Hz}$, $2^{\prime}-\mathrm{H}$ and $\left.6^{\prime}-\mathrm{H}\right),{ }^{13} \mathrm{C}$ NMR $\delta \mathrm{ppm} 10.6(\mathrm{C}-16 \mathrm{a}), 16.7(\mathrm{C}-18), 25.4$, $25.7,29.9,30.5,33.9(\mathrm{C}-13), 35.0,38.5,43.7,47.2,69.9\left(\mathrm{OCH}_{2}\right)$, 77.4(C-16), 79.9(C-17), $112.4(\mathrm{C}-2), \quad 114.6(\mathrm{C}-4), \quad 126.1(\mathrm{C}-1)$, 127.4(2C: C-2', $\left.6^{\prime}\right), 127.8\left(\mathrm{C}-4^{\prime}\right), 128.5\left(2 \mathrm{C}: \mathrm{C}^{\prime} 3^{\prime}, 5^{\prime}\right), 132.8(\mathrm{C}-10)$, 137.3(C-1'), 137.8(C-5), 156.8(C-3). MS $m / z(\%): 504$ (32), 503 (100), 214 (21), 113 (26).

Continued elution yielded $\mathbf{1 0 b}$ as a white solid (64 mg, 25\%). Mp $112-113^{\circ} \mathrm{C}, R_{f}=0.47^{\mathrm{C}}$. Anal. Calcd. for $\mathrm{C}_{26} \mathrm{H}_{31} \mathrm{IO}_{2}$ : C, 62.15; $\mathrm{H}, 6.22$. Found: C, 62.28; $\mathrm{H}, 6.18 .{ }^{1} \mathrm{H}$ NMR $\delta$ ppm $1.02\left(\mathrm{~s}, 3 \mathrm{H}, 18-\mathrm{H}_{3}\right), 2.84(\mathrm{~m}$, $\left.2 \mathrm{H}, 6-\mathrm{H}_{2}\right), 3.20\left(\mathrm{~m}, 2 \mathrm{H}, 16 \mathrm{a}-\mathrm{H}_{2}\right), 3.40$ and $3.56(2 \times \mathrm{m}, 2 \times 1 \mathrm{H}, 17-$ $\left.\mathrm{H}_{2}\right), 4.23(\mathrm{~m}, 1 \mathrm{H}, 16-\mathrm{H}), 5.04\left(\mathrm{~s}, 2 \mathrm{H}, \mathrm{OCH}_{2}\right), 6.72(\mathrm{~d}, 1 \mathrm{H}, J=2.3 \mathrm{~Hz}$, $4-\mathrm{H}), \quad 6.79(\mathrm{dd}, \quad 1 \mathrm{H}, J=8.5 \mathrm{~Hz}, J=2.3 \mathrm{~Hz}, \quad 2-\mathrm{H}), \quad 7.24(\mathrm{~d}, \quad 1 \mathrm{H}$, $J=8.5 \mathrm{~Hz}, 1-\mathrm{H}), 7.32\left(\mathrm{t}, 1 \mathrm{H}, J=7.3 \mathrm{~Hz}, 4^{\prime}-\mathrm{H}\right), 7.38(\mathrm{t}, 2 \mathrm{H}, J=7.3 \mathrm{~Hz}$, $3^{\prime}-\mathrm{H}$ and $\left.5^{\prime}-\mathrm{H}\right), 7.43\left(\mathrm{~d}, 2 \mathrm{H}, J=7.3 \mathrm{~Hz}, 2^{\prime}-\mathrm{H}\right.$ and $\left.6^{\prime}-\mathrm{H}\right),{ }^{13} \mathrm{C}$ NMR $\delta$ ppm 6.9(C-16a), 15.9(C-18), 25.3, 25.6, 29.8, 30.5, 34.2(C-13), $35.5, \quad 38.3, \quad 41.7, \quad 43.7, \quad 69.9\left(\mathrm{OCH}_{2}\right), \quad 72.5(\mathrm{C}-17), \quad 73.7(\mathrm{C}-16)$, 112.4(C-2), 114.6(C-4), 126.0(C-1), 127.4(2C: C-2',6'), 127.8(C-4'), 128.5(2C: C-3',5'), 132.8(C-10), 137.3(C-1'), 137.8(C-5), 156.8(C3). MS $m / z$ (\%): 504 (30), 503 (100).
2.1.6. 3-Benzyloxy-16 $\beta$-phenylselenylmethyl-17-oxa-D-homoestra1,3,5(10)-triene (9c) and 3-benzyloxy-16 $\alpha$-phenylselenylmethyl-17oxa-D-homoestra-1,3,5(10)-triene (10c)

Compound 6 (188 mg, $0.50 \mathrm{mmol}$ ) was dissolved in acetonitrile ( $5 \mathrm{ml}$ ), and phenylselenyl bromide $(118 \mathrm{mg}, 0.50 \mathrm{mmol}$ ) was added in three portions. After stirring for $1 \mathrm{~h}$ at room temperature, potassium carbonate $(70 \mathrm{mg}, 0.50 \mathrm{mmol})$ was added and the stirring was continued for $1 \mathrm{~h}$. The solvent was evaporated off and the residue was subjected to column chromatography with $70 \%$ dichloromethane/30\% hexane. 9c eluted first as a white solid (192 mg, 36\%). Mp $135-137^{\circ} \mathrm{C}, R_{f}=0.47^{\mathrm{C}}$. Anal. Calcd. for $\mathrm{C}_{32} \mathrm{H}_{36} \mathrm{O}_{2} \mathrm{Se}: \mathrm{C}, 72.30 ; \mathrm{H}$, 6.83. Found: $\mathrm{C}, 72.44 ; \mathrm{H}, 6.95 .{ }^{1} \mathrm{H}$ NMR $\delta \mathrm{ppm} 1.01\left(\mathrm{~s}, 3 \mathrm{H}, 18-\mathrm{H}_{3}\right)$ 2.83( $\left.\mathrm{m}, 2 \mathrm{H}, 6-\mathrm{H}_{2}\right), 3.06(\mathrm{~m}, 1 \mathrm{H})$ and 3.14(overlapping multiplets, $2 \mathrm{H}$ ) and 3.55(overlapping multiplets, $2 \mathrm{H}$ ): $16-\mathrm{H}$ and $16 \mathrm{a}-\mathrm{H}_{2}$ and $17-\mathrm{H}_{2}, 5.04\left(\mathrm{~s}, 2 \mathrm{H}, \mathrm{OCH}_{2}\right), 6.72(\mathrm{~d}, 1 \mathrm{H}, J=2.3 \mathrm{~Hz}, 4-\mathrm{H}), 6.79(\mathrm{dd}, 1 \mathrm{H}$ $J=8.5 \mathrm{~Hz}, J=2.3 \mathrm{~Hz}, 2-\mathrm{H}), 7.21(\mathrm{~d}, 1 \mathrm{H}, J=8.5 \mathrm{~Hz}, 1-\mathrm{H}), 7.24$ 7.28 (overlapping multiplets, $3 \mathrm{H}$ ) and $7.54(\mathrm{~m}, 2 \mathrm{H}): 2^{\prime \prime}, 3^{\prime \prime}, 4^{\prime \prime}, 5^{\prime \prime}$, $6^{\prime \prime}-\mathrm{H}, 7.32\left(\mathrm{t}, 1 \mathrm{H}, J=7.3 \mathrm{~Hz}, 4^{\prime}-\mathrm{H}\right), 7.38\left(\mathrm{t}, 2 \mathrm{H}, J=7.3 \mathrm{~Hz}, 3^{\prime}-\mathrm{H}\right.$ and $\left.5^{\prime}-\mathrm{H}\right), 7.43\left(\mathrm{~d}, 2 \mathrm{H}, J=7.3 \mathrm{~Hz}, 2^{\prime}-\mathrm{H}\right.$ and $\left.6^{\prime}-\mathrm{H}\right),{ }^{13} \mathrm{C}$ NMR $\delta \mathrm{ppm}$ 16.6(C-18), 25.5, 25.7, 29.9, 30.3, 33.8, 34.0(C-13), 35.2, 38.5(C-8), 43.7(C-9), 47.4(C-14), 69.9 $\left(\mathrm{OCH}_{2}\right), \quad 77.9(\mathrm{C}-16), \quad 80.0(\mathrm{C}-17)$, 112.4(C-2), 114.6(C-4), 126.1(C-1), 126.7(2C: C-2',6'), 127.4(2C: C-3', $\left.5^{\prime}\right), 127.8\left(C-4^{\prime}\right), 128.5\left(2 \mathrm{C}: C-3^{\prime \prime}, 5^{\prime \prime}\right), 129.0\left(C-4^{\prime \prime}\right), 130.8\left(C-1^{\prime \prime}\right)$, 132.5(2C: C-2" $\left.6^{\prime \prime}\right), 132.9(C-10), 137.3\left(C-1^{\prime}\right), 137.8(C-5), 156.8(C-3)$. MS $m / z$ (\%): 550 (34), 549 (100).

Continued elution yielded 10c (192 mg, 36\%). Mp $142-143^{\circ} \mathrm{C}$, $R_{f}=0.40^{\mathrm{C}}$. Anal. Calcd. for $\mathrm{C}_{32} \mathrm{H}_{36} \mathrm{O}_{2} \mathrm{Se}: \mathrm{C}, 72.30 ; \mathrm{H}, 6.83$. Found: $\mathrm{C}$, 72.38; $\mathrm{H}, 6.95 .{ }^{1} \mathrm{H}$ NMR $\delta \mathrm{ppm} 1.00\left(\mathrm{~s}, 3 \mathrm{H}, 18-\mathrm{H}_{3}\right), 2.80(\mathrm{~m}, 2 \mathrm{H}, 6-$ $\left.\mathrm{H}_{2}\right), 3.11$ and $3.40\left(2 \times \mathrm{m}, 2 \times 1 \mathrm{H}, 16 \mathrm{a}-\mathrm{H}_{2}\right), 3.19$ and $3.32(2 \times \mathrm{d}$, $\left.2 \times 1 \mathrm{H}, J=11.2 \mathrm{~Hz}, 17-\mathrm{H}_{2}\right), 4.24(\mathrm{~m}, 1 \mathrm{H}, 16-\mathrm{H}), 5.03\left(\mathrm{~d}, 2 \mathrm{H}, \mathrm{OCH}_{2}\right)$, $6.71(\mathrm{~d}, 1 \mathrm{H}, J=2.3 \mathrm{~Hz}, 4-\mathrm{H}), 6.78(\mathrm{dd}, 1 \mathrm{H}, J=8.5 \mathrm{~Hz}, J=2.3 \mathrm{~Hz}, 2-\mathrm{H})$ 7.19(d, $1 \mathrm{H}, J=8.5 \mathrm{~Hz}, 1-\mathrm{H}$ ), 7.22-7.26(overlapping multiplets. $3 \mathrm{H}$ ): $3^{\prime \prime}, 4^{\prime \prime}, 5^{\prime \prime}-\mathrm{H}, 7.32\left(\mathrm{t}, 1 \mathrm{H}, J=7.2 \mathrm{~Hz}, 4^{\prime}-\mathrm{H}\right), 7.38\left(\mathrm{t}, 2 \mathrm{H}, J=7.2 \mathrm{~Hz}, 3^{\prime}-\mathrm{H}\right.$ and $5^{\prime}-\mathrm{H}$ ), 7.43(d. $2 \mathrm{H}, J=7.2 \mathrm{~Hz}, 2^{\prime}-\mathrm{H}$ and $\left.6^{\prime}-\mathrm{H}\right), 7.54\left(\mathrm{~m}, 2 \mathrm{H}, 2^{\prime \prime}-\mathrm{H}\right.$ and $\left.66^{\prime \prime}-\mathrm{H}\right),{ }^{13} \mathrm{C}$ NMR $\delta$ ppm 16.1(C-18), 25.4, 25.5, 25.9, 29.4(C16a), 29.8(C-6), 34.2, 35.6, 38.4(C-8), 41.8(C-9), 43.7(C-14), 69.9 $\left(\mathrm{OCH}_{2}\right), 72.8(\mathrm{C}-17), 73.1(\mathrm{C}-16), 112.4(\mathrm{C}-2), 114.6(\mathrm{C}-4), 126.1$

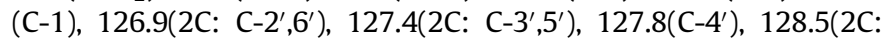
C-3", $\left.5^{\prime \prime}\right), 12.91\left(\mathrm{C}-4^{\prime \prime}\right), 130.1\left(\mathrm{C}-1^{\prime \prime}\right), 132.7\left(2 \mathrm{C}: \mathrm{C}-2^{\prime \prime}, 6^{\prime \prime}\right), 132.9(\mathrm{C}-10)$, 137.3(C-1'), 137.9(C-5), 156.8(C-3). MS $m / z$ (\%): 549 (100).

\subsubsection{3-Benzyloxy-16 $\beta$-bromomethyl-17-oxa-D-homoestra-1,3,5(10)- trien-17a-one (11a)}

Compound 7 (195 mg, $0.50 \mathrm{mmol}$ ) was dissolved in dichloromethane $(5 \mathrm{ml})$, and $N$-bromosuccinimide $(89 \mathrm{mg}, 0.50 \mathrm{mmol})$ was added. The mixture was stirred at room temperature for $1 \mathrm{~h}$. The solvent was evaporated off and the residue was subjected to column chromatography with dichloromethane as eluent. 11a was obtained (193 $\mathrm{mg}, 82 \%)$. Mp $150-155^{\circ} \mathrm{C}, R_{f}=0.63^{\mathrm{D}}$. Anal. Calcd. for $\mathrm{C}_{26} \mathrm{H}_{29} \mathrm{BrO}_{3}$ : C, 66.53; H, 6.23. Found: C, 66.72; $\mathrm{H}, 6.35$. ${ }^{1} \mathrm{H}$ NMR $\delta \mathrm{ppm} 1.26\left(\mathrm{~s}, 3 \mathrm{H}, 18-\mathrm{H}_{3}\right), 2.88\left(\mathrm{~m}, 2 \mathrm{H}, 6-\mathrm{H}_{2}\right), 3.56-$ 3.62(overlapping multiplets, $\left.2 \mathrm{H}, 16 \mathrm{a}-\mathrm{H}_{2}\right), 4.54(\mathrm{~m}, 1 \mathrm{H}, 16-\mathrm{H})$, 5.04(s, $\left.2 \mathrm{H}, \mathrm{OCH}_{2}\right), 6.74(\mathrm{~d}, 1 \mathrm{H}, J=2.3 \mathrm{~Hz}, 4-\mathrm{H}), 6.80(\mathrm{dd}, 1 \mathrm{H}$, $J=8.5 \mathrm{~Hz}, J=2.3 \mathrm{~Hz}, 2-\mathrm{H}), 7.22(\mathrm{~d}, 1 \mathrm{H}, J=8.5 \mathrm{~Hz}, 1-\mathrm{H}), 7.32(\mathrm{t}, 1 \mathrm{H}$, $\left.J=7.3 \mathrm{~Hz}, 4^{\prime}-\mathrm{H}\right), 7.38\left(\mathrm{t}, 2 \mathrm{H}, J=7.3 \mathrm{~Hz}, 3^{\prime}-\mathrm{H}\right.$ and $\left.5^{\prime}-\mathrm{H}\right), 7.42(\mathrm{~d}, 2 \mathrm{H}$, $J=7.3 \mathrm{~Hz}, 2^{\prime}-\mathrm{H}$ and $\left.6^{\prime}-\mathrm{H}\right),{ }^{13} \mathrm{C}$ NMR $\delta$ ppm $18.5(\mathrm{C}-18), 25.4,26.2$, 26.3, 29.7, 34.2, 35.3, 37.7, 41.3(C-13), 42.6, 43.1, 70.0 $\left(\mathrm{OCH}_{2}\right)$, 78.3(C-16), 112.6(C-2), 114.6(C-4), 126.2 and $127.4(2 \mathrm{C})$ and 127.9 and $128.5(2 \mathrm{C})$ : $\mathrm{C}-1,2^{\prime}, 3^{\prime}, 4^{\prime}, 5^{\prime}, 6^{\prime}, 131.9(\mathrm{C}-10), 137.2\left(\mathrm{C}-1^{\prime}\right)$, 137.4(C-5), 157.0(C-3), 176.3(C-17). MS m/z (\%): 491 (63), 469 (100).

\subsubsection{3-Benzyloxy-16 $\beta$-iodomethyl-17-oxa-D-homoestra-1,3,5(10)-} trien-17a-one (11b)

Compound 7 (195 mg, $0.50 \mathrm{mmol}$ ) was dissolved in a $1: 1 \mathrm{mix}-$ ture $(5 \mathrm{ml})$ of dichloromethane and tetrahydrofuran, and saturated 
sodium hydrogencarbonate solution $(10 \mathrm{ml}, \mathrm{pH}=9)$ and iodine ( $127 \mathrm{mg}, 0.50 \mathrm{mmol}$ ) were added. The mixture was stirred for $1 \mathrm{~h}$ at room temperature, diluted with water and extracted with dichloromethane. The organic phase was separated out and washed with a saturated solution of sodium thiosulfate and with water. The organic phase was dried over sodium sulfate and evaporated, and the residue was subjected to column chromatography with dichloromethane as eluent. 11b was obtained $(217 \mathrm{mg}, 84 \%)$. Mp $158-160^{\circ} \mathrm{C}, R_{f}=0.66^{\mathrm{D}}$. Anal. Calcd. for $\mathrm{C}_{26} \mathrm{H}_{29} \mathrm{IO}_{3}: \mathrm{C}, 60.47 ; \mathrm{H}$, 5.66. Found: C, 60.32; $\mathrm{H}, 5.75 .{ }^{1} \mathrm{H}$ NMR $\delta \mathrm{ppm} 1.26\left(\mathrm{~s}, 3 \mathrm{H}, 18-\mathrm{H}_{3}\right)$, $2.89\left(\mathrm{~m}, 2 \mathrm{H}, 6-\mathrm{H}_{2}\right), 3.43\left(\mathrm{~m}, 2 \mathrm{H}, 16 \mathrm{a}-\mathrm{H}_{2}\right), 4.22(\mathrm{~m}, 1 \mathrm{H}, 16-\mathrm{H})$, 5.04(s, $\left.2 \mathrm{H}, \mathrm{OCH}_{2}\right), 6.73(\mathrm{~d}, 1 \mathrm{H}, J=2.3 \mathrm{~Hz}, 4-\mathrm{H}), 6.80(\mathrm{dd}, 1 \mathrm{H}$, $J=8.5 \mathrm{~Hz}, J=2.3 \mathrm{~Hz}, 2-\mathrm{H}), 7.21(\mathrm{~d}, 1 \mathrm{H}, J=8.5 \mathrm{~Hz}, 1-\mathrm{H}), 7.32(\mathrm{t}, 1 \mathrm{H}$, $\left.J=7.3 \mathrm{~Hz}, 4^{\prime}-\mathrm{H}\right), 7.38\left(\mathrm{t}, 2 \mathrm{H}, J=7.3 \mathrm{~Hz}, 3^{\prime}-\mathrm{H}\right.$ and $\left.5^{\prime}-\mathrm{H}\right), 7.42(\mathrm{~d}, 2 \mathrm{H}$, $J=7.3 \mathrm{~Hz}, 2^{\prime}-\mathrm{H}$ and $\left.6^{\prime}-\mathrm{H}\right),{ }^{13} \mathrm{C}$ NMR $\delta \mathrm{ppm} 9.3(\mathrm{C}-16 \mathrm{a}), 18.7(\mathrm{C}-18)$, $25.4, \quad 26.3, \quad 28.2, \quad 29.7, \quad 34.2, \quad 37.7,41.2(\mathrm{C}-13), 42.7,43.2$, 69.9 $\left(\mathrm{OCH}_{2}\right), \quad 78.3(\mathrm{C}-16), \quad 112.6(\mathrm{C}-2), \quad 114.6(\mathrm{C}-4), \quad 126.2$ and 127.4(2C) and 127.9 and $128.5(2 \mathrm{C})$ : $\mathrm{C}-1,2^{\prime}, 3^{\prime}, 4^{\prime}, 5^{\prime}, 6^{\prime}, 131.9(\mathrm{C}-10)$, 137.2(C-1'), 137.3(C-5), 156.9(C-3), 176.4(C-17). MS $m / z(\%): 517$ (58), 113 (100).

\subsubsection{3-Benzyloxy-16 $\beta$-phenylselenylmethyl-17-oxa-D-homoestra- 1,3,5(10)-trien-17a-one (11c)}

Compound 7 ( $195 \mathrm{mg}, 0.50 \mathrm{mmol}$ ) was dissolved in acetonitrile ( $5 \mathrm{ml}$ ), and phenylselenyl bromide ( $118 \mathrm{mg}, 0.50 \mathrm{mmol}$ ) was added in three portions. After stirring for $1 \mathrm{~h}$ at room temperature, potassium carbonate ( $70 \mathrm{mg}, 0.5 \mathrm{mmol}$ ) was added and the stirring was continued for $1 \mathrm{~h}$. The solvent was evaporated off and the residue was subjected to column chromatography with dichloromethane as eluent. 11c was obtained $(216 \mathrm{mg}, 79 \%)$. Mp $175-178{ }^{\circ} \mathrm{C}$, $R_{f}=0.66^{\mathrm{D}}$. Anal. Calcd. for $\mathrm{C}_{32} \mathrm{H}_{34} \mathrm{O}_{3} \mathrm{Se}: \mathrm{C}, 70.45 ; \mathrm{H}, 6.28$. Found: C, 70.62; H, 6.14. ${ }^{1} \mathrm{H}$ NMR $\delta \mathrm{ppm} 1.26\left(\mathrm{~s}, 3 \mathrm{H}, 18-\mathrm{H}_{3}\right), 2.86(\mathrm{~m}, 2 \mathrm{H}$, $\left.6-\mathrm{H}_{2}\right), 3.15$ and $3.29\left(2 \times \mathrm{m}, 2 \times 1 \mathrm{H}, 16 \mathrm{a}-\mathrm{H}_{2}\right), 4.52(\mathrm{~m}, 1 \mathrm{H}, 16-\mathrm{H})$, $5.04\left(\mathrm{~s}, 2 \mathrm{H}, \mathrm{OCH}_{2}\right), 6.73(\mathrm{~d}, 1 \mathrm{H}, J=2.3 \mathrm{~Hz}, 4-\mathrm{H}), 6.80(\mathrm{dd}, 1 \mathrm{H}, J=$ $8.5 \mathrm{~Hz}, J=2.3 \mathrm{~Hz}, 2-\mathrm{H}$ ), 7.21 (d, $1 \mathrm{H}, J=8.5 \mathrm{~Hz}, 1-\mathrm{H}$ ), 7.26-7.34(overlapping multiplets, $\left.4 \mathrm{H}: 4^{\prime}, 3^{\prime \prime}, 4^{\prime \prime}, 5^{\prime \prime}-\mathrm{H}\right), 7.39\left(\mathrm{t}, 2 \mathrm{H}, J=7.3 \mathrm{~Hz}, 3^{\prime}-\mathrm{H}\right.$ and $\left.5^{\prime}-\mathrm{H}\right), 7.43\left(\mathrm{~d}, 2 \mathrm{H}, J=7.3 \mathrm{~Hz}, 2^{\prime}-\mathrm{H}\right.$ and $\left.6^{\prime}-\mathrm{H}\right), 7.56\left(\mathrm{~m}, 2 \mathrm{H}, 2^{\prime \prime}-\mathrm{H}\right.$ and $\left.6^{\prime \prime}-\mathrm{H}\right) .{ }^{13} \mathrm{C}$ NMR $\delta$ ppm 18.6(C-18), 25.4, 26.2, 27.4, 29.7, 33.3, $34.2,37.8,41.3(\mathrm{C}-13), 42.7,43.5,69.9\left(\mathrm{OCH}_{2}\right), 79.9(\mathrm{C}-16), 112.2(\mathrm{C}-$ 2), 114.6(C-4), 126.2 and $127.4(3 \mathrm{C})$ and 127.9 and $128.5(2 \mathrm{C})$ and 129.3(2C): C-1, $2^{\prime}, 3^{\prime}, 4^{\prime}, 5^{\prime}, 6^{\prime}, 3^{\prime \prime}, 4^{\prime \prime}, 5^{\prime \prime}, 129.6\left(\mathrm{C}-1^{\prime \prime}\right), 132.0(\mathrm{C}-10)$, 132.8(2C: C-2", $\left.6^{\prime \prime}\right), 137.2\left(C-1^{\prime}\right), 137.4(C-5), 157.0(C-3), 176.8(C-17)$. MS m/z (\%): 569 (100), 567 (53), 501 (47), 91 (42).

\subsubsection{General procedure for the preparation of derivatives $\mathbf{1 2 a}$ and $12 d$}

A suspension of $6(188 \mathrm{mg}, 0.50 \mathrm{mmol})$ or $12 c(210 \mathrm{mg}, 0.50$ $\mathrm{mmol})$ and $\mathrm{Pd} / \mathrm{C}(0.30 \mathrm{~g}, 10 \%)$ in ethyl acetate $(20 \mathrm{ml})$ was subjected to 20 bar of hydrogen pressure at room temperature for 3 h. The catalyst was then removed by filtration through a short pad of silica gel. After evaporation of the solvent in vacuo, the crude product was subjected to column chromatography with dichloromethane as eluent.

2.1.10.1. 3-Hydroxy-13 $\alpha$-hydroxymethyl-14 $\beta$-propyl-des-D-estra-1,3, 5(10)-triene (12a). According to Section 2.1.10, compound 6 (188 $\mathrm{mg}, 0.50 \mathrm{mmol}$ ) was subjected to hydrogenolysis. The chromatographic purification of the crude product yielded 12a (118 mg, 87\%). Mp 60-62 ${ }^{\circ} \mathrm{C}, R_{f}=0.17^{\mathrm{D}}$. Anal. Calcd. for $\mathrm{C}_{19} \mathrm{H}_{28} \mathrm{O}_{2}$ : C, 79.12; H, 9.78. Found: C, 78.95; H, 9.86. ${ }^{1} \mathrm{H}$ NMR $\delta$ ppm 0.77(s, $\left.3 \mathrm{H}, 18-\mathrm{H}_{3}\right), 2.82\left(\mathrm{~m}, 2 \mathrm{H}, 6-\mathrm{H}_{2}\right), 3.35$ and $3.52(2 \times \mathrm{d}, 2 \times 1 \mathrm{H}$, $\left.J=10.9 \mathrm{~Hz}, 17-\mathrm{H}_{2}\right), 6.56(\mathrm{~d}, 1 \mathrm{H}, J=2.3 \mathrm{~Hz}, 4-\mathrm{H}), 6.63(\mathrm{dd}, 1 \mathrm{H}$, $J=8.5 \mathrm{~Hz}, J=2.3 \mathrm{~Hz}, 2-\mathrm{H}), 7.16(\mathrm{~d}, 1 \mathrm{H}, J=8.5 \mathrm{~Hz}, 1-\mathrm{H}),{ }^{13} \mathrm{C} \mathrm{NMR} \delta$ ppm 14.7 and 15.9: C-18 and Ac-Me, 25.0, 26.4, 27.4, 30.5, $31.2,35.6,38.8(\mathrm{C}-13), 41.8,43.5,45.3,71.4(\mathrm{C}-17), 112.8(\mathrm{C}-2)$,
114.9(C-4), 126.7(C-1), 132.9(C-10), 138.3(C-5), 153.5(C-3). MS $m / z(\%): 289$ (100).

2.1.10.2. 13 $\alpha$-Acetoxymethyl-3-hydroxy-14 $\beta$-propyl-des-D-estra-1,3, 5(10)-triene (12d). According to Section 2.1.10, compound 12c (210 mg, $0.5 \mathrm{mmol}$, described in Section 2.1.11) was subjected to hydrogenolysis. The chromatographic purification of the crude product yielded 12d $(145 \mathrm{mg}, 88 \%)$. Mp $84-90^{\circ} \mathrm{C}, R_{f}=0.37^{\mathrm{D}}$. Anal. Calcd. for $\mathrm{C}_{21} \mathrm{H}_{30} \mathrm{O}_{3}$ : C, 76.33; H, 9.15. Found: C, 76.45; H. 9.22. ${ }^{1} \mathrm{H}$ NMR $\delta \mathrm{ppm} 0.83\left(\mathrm{~s}, 3 \mathrm{H}, 18-\mathrm{H}_{3}\right), 2.09(\mathrm{~s}, 3 \mathrm{H}, \mathrm{Ac}-\mathrm{Me}), 2.82(\mathrm{~m}$, $\left.2 \mathrm{H}, 6-\mathrm{H}_{2}\right), 3.86$ and $3.92\left(2 \times \mathrm{d}, 2 \times 1 \mathrm{H}, J=11.2 \mathrm{~Hz}, 17-\mathrm{H}_{2}\right), 4.75(\mathrm{~s}$, $1 \mathrm{H}, \mathrm{OH}), 6.56(\mathrm{~d}, 1 \mathrm{H}, J=2.3 \mathrm{~Hz}, 4-\mathrm{H}), 6.63(\mathrm{dd}, 1 \mathrm{H}, J=8.5 \mathrm{~Hz}$, $J=2.3 \mathrm{~Hz}, 2-\mathrm{H}), 7.16(\mathrm{~d}, 1 \mathrm{H}, J=8.5 \mathrm{~Hz}, 1-\mathrm{H}),{ }^{13} \mathrm{C}$ NMR $\delta \mathrm{ppm} 14.5$ and 15.9: C-18 and Ac-Me, 24.8, 26.3, 27.3, 30.5, 31.3, 36.0, 37.4(C-13), 41.7, 43.4, 45.8, 72.3(C-17), 112.7(C-2), 114.9(C-4), 126.7(C-1), 132.7(C-10), 138.2(C-5), 153.4(C-3), 170.0(AC-CO). MS $m / z$ (\%): 385 (100).

\subsubsection{General procedure for the synthesis of derivatives $\mathbf{1 2 c}$ and $\mathbf{1 2 b}$}

Compound 6 (188 mg, $0.50 \mathrm{mmol})$ or 12a (145 mg, $0.50 \mathrm{mmol})$ and acetic anhydride $(0.1 \mathrm{ml}, 1 \mathrm{mmol})$ were mixed with silica gel (500 mg), placed into a pressure tube equipped with a stirrer bar and inserted into the cavity of a Discover SP microwave system apparatus. The mixture was heated at $160{ }^{\circ} \mathrm{C}$ for $5 \mathrm{~min}$, then poured onto water and extracted with diethyl ether. The organic phase was washed with water until neutral, dried over anhydrous sodium sulfate, filtered and evaporated. The crude product was subjected to column chromatography.

2.1.11.1. 3-Acetoxy-13 $\alpha$-acetoxymethyl-14 $\beta$-propyl-des-D-estra-1,3, 5(10)-triene (12b). According to Section 2.1.11, compound 6 $(188 \mathrm{mg}, 0.50 \mathrm{mmol})$ was reacted with acetic anhydride $(0.1 \mathrm{ml}$, $1 \mathrm{mmol}$ ) in a microwave reactor. The crude product was subjected to column chromatography with dichloromethane as eluent, yielding 12b $(160 \mathrm{mg}, 86 \%)$. Oil, $R_{f}=0.69^{\mathrm{D}}$. Anal. Calcd. for $\mathrm{C}_{23} \mathrm{H}_{32} \mathrm{O}_{4}: \mathrm{C}$, 74.16; H, 8.66. Found: C, 74.25; H, 8.82. ${ }^{1} \mathrm{H}$ NMR $\delta$ ppm $0.83(\mathrm{~s}, 3 \mathrm{H}$, $\left.18-\mathrm{H}_{3}\right), 2.09$ and $2.28(2 \times \mathrm{s}, 2 \times 3 \mathrm{H}, 2 \times \mathrm{Ac}-\mathrm{Me}), 2.86\left(\mathrm{~m}, 2 \mathrm{H}, 6-\mathrm{H}_{2}\right)$, 3.86 and $3.92\left(2 \times \mathrm{d}, 2 \times 1 \mathrm{H}, J=11.3 \mathrm{~Hz}, 17-\mathrm{H}_{2}\right), 6.79(\mathrm{~d}, 1 \mathrm{H}$, $J=2.3 \mathrm{~Hz}, 4-\mathrm{H}), 6.83(\mathrm{dd}, 1 \mathrm{H}, J=8.5 \mathrm{~Hz}, J=2.3 \mathrm{~Hz}, 2-\mathrm{H}), 7.27(\mathrm{~d}$, $1 \mathrm{H}, J=8.5 \mathrm{~Hz}, 1-\mathrm{H}),{ }^{13} \mathrm{C}$ NMR $\delta$ ppm 14.1 and 15.5 and 20.7: C-18 and 17-Ac-Me and 3-Ac-Me, 24.4, 25.8, 26.8, 30.0, 30.9, 35.6, 36.9(C-13), 40.9, 43.3, 45.4, 71.7(C-17), 118.2, 120.9, 126.2(C-4), 137.6 and 137.8: C-5 and C-10, 148.0(C-3), 169.4 and 170.9: C17-Ac-CO and C-3-Ac-CO. MS m/z (\%): 427 (100).

2.1.11.2. 13 $\alpha$-Acetoxymethyl-3-benzyloxy-14 $\beta$-(prop-2-en-yl)-des-Destra-1,3,5(10)-triene (12c). According to Section 2.1.11, compound 12a $(145 \mathrm{mg}, 0.50 \mathrm{mmol})$ was reacted with acetic anhydride $(0.1 \mathrm{ml}, 1 \mathrm{mmol})$ in a microwave reactor. The crude product of 12c was subjected to column chromatography with $2 \%$ ethyl acetate/98\% dichloromethane as eluent, yielding 12c (191 mg, 91\%). Mp $90-92{ }^{\circ} \mathrm{C}, R_{f}=0.78^{\mathrm{D}}$. Anal. Calcd. for $\mathrm{C}_{28} \mathrm{H}_{34} \mathrm{O}_{3}: \mathrm{C}, 80.35 ; \mathrm{H}$, 8.19. Found: $\mathrm{C}, 80.12 ; \mathrm{H}, 8.22 .{ }^{1} \mathrm{H}$ NMR $\delta \mathrm{ppm} 0.87\left(\mathrm{~s}, 3 \mathrm{H}, 18-\mathrm{H}_{3}\right)$, $2.09(\mathrm{~s}, 3 \mathrm{H}, \mathrm{Ac}-\mathrm{Me}), 2.85\left(\mathrm{~m}, 2 \mathrm{H}, 6-\mathrm{H}_{2}\right), 3.84$ and $4.00(2 \times \mathrm{d}$, $\left.2 \times 1 \mathrm{H}, J=11.2 \mathrm{~Hz}, 17-\mathrm{H}_{2}\right), 4.97\left(\mathrm{~m}, 2 \mathrm{H}, 16 \mathrm{a}-\mathrm{H}_{2}\right), 5.04(\mathrm{~s}, 2 \mathrm{H}$, $\left.\mathrm{OCH}_{2}\right), 5.84(\mathrm{~m}, 1 \mathrm{H}, 16-\mathrm{H}), 6.72(\mathrm{~d}, 1 \mathrm{H}, J=2.3 \mathrm{~Hz}, 4-\mathrm{H}), 6.79(\mathrm{dd}$, $1 \mathrm{H}, J=8.5 \mathrm{~Hz}, J=2.3 \mathrm{~Hz}, 2-\mathrm{H}), 7.21(\mathrm{~d}, 1 \mathrm{H}, J=8.5 \mathrm{~Hz}, 1-\mathrm{H}), 7.30(\mathrm{t}$, $\left.1 \mathrm{H}, J=7.3 \mathrm{~Hz}, 4^{\prime}-\mathrm{H}\right), 7.38\left(\mathrm{t}, 2 \mathrm{H}, J=7.3 \mathrm{~Hz}, 3^{\prime}-\mathrm{H}\right.$ and $\left.5^{\prime}-\mathrm{H}\right), 7.43(\mathrm{~d}$, $2 \mathrm{H}, J=7.3 \mathrm{~Hz}, 2^{\prime}-\mathrm{H}$ and $\left.6^{\prime}-\mathrm{H}\right),{ }^{13} \mathrm{C}$ NMR $\delta$ ppm 16.2 and 20.9: C18 and Ac-Me, 26.2, 27.5, 30.4, 32.7, 36.3, 37.6(C-13), 41.3, 43.4, $44.8,69.9\left(\mathrm{OCH}_{2}\right), 71.9(\mathrm{C}-17), 112.4(\mathrm{C}-2), 114.4(\mathrm{C}-16 \mathrm{a}), 114.5(\mathrm{C}-$ 4), 126.4(C-1), 127.4(2C: C-2',6' $)$ 127.8(C-4'), 128.5(2C: C-3',5'), 132.9(C-10), 137.3(C-1'), 137.9(C-5), 139.7(C-16), 156.8(C-3), 171.2(C-17). MS $m / z$ (\%): 431 (100). 
2.1.12. Synthesis of 3-benzyloxy-13 $\alpha$-(p-tolylsulfonyloxymethyl)-14 $\beta$ (prop-2-en-yl)-des-D-estra-1,3,5(10)-triene (12e)

Compound 6 (188 mg, $0.50 \mathrm{mmol}$ ) was dissolved in pyridine $(3 \mathrm{ml})$, then cooled in an ice-water bath and $286 \mathrm{mg}(1.50 \mathrm{mmol})$ of $p$-tolylsulfonyl chloride was added in small portions. After stirring for $3 \mathrm{~h}$ at room temperature, the reaction mixture was diluted with water $(50 \mathrm{ml})$ and extracted with dichloromethane. The organic phase was washed with water until neutral, dried over anhydrous sodium sulfate, filtered and evaporated. The crude product was subjected to flash chromatography with dichloromethane as eluent, yielding 12e $(252 \mathrm{mg}, 95 \%)$. Mp $105-110^{\circ} \mathrm{C}$, $R_{f}=0.82^{\text {D }}$. Anal. Calcd. for $\mathrm{C}_{33} \mathrm{H}_{38} \mathrm{O}_{4} \mathrm{~S}: \mathrm{C}, 74.68 ; \mathrm{H}, 7.22$. Found: C, 74.83; $\mathrm{H}, 7.35 .{ }^{1} \mathrm{H}$ NMR $\delta \mathrm{ppm} 0.81\left(\mathrm{~s}, 3 \mathrm{H}, 18-\mathrm{H}_{3}\right), 2.47(\mathrm{~s}, 3 \mathrm{H}$, Ts$\mathrm{Me}), 2.82\left(\mathrm{~m}, 2 \mathrm{H}, 6-\mathrm{H}_{2}\right), 3.74$ and $3.90(2 \times \mathrm{d}, 2 \times 1 \mathrm{H}, J=9.4 \mathrm{~Hz}$, $\left.17-\mathrm{H}_{2}\right), 4.92\left(\mathrm{~m}, 2 \mathrm{H}, 16 \mathrm{a}-\mathrm{H}_{2}\right), 5.03\left(\mathrm{~s}, 2 \mathrm{H}, \mathrm{OCH}_{2}\right), 5.75(\mathrm{~m}, 1 \mathrm{H}, 16-$ $\mathrm{H}), 6.71(\mathrm{~d}, 1 \mathrm{H}, J=2.3 \mathrm{~Hz}, 4-\mathrm{H}), 6.78(\mathrm{dd}, 1 \mathrm{H}, J=8.5 \mathrm{~Hz}, J=2.3 \mathrm{~Hz}$, $2-\mathrm{H}), 7.18(\mathrm{~d}, 1 \mathrm{H}, J=8.5 \mathrm{~Hz}, 1-\mathrm{H}), 7.32\left(\mathrm{t}, 1 \mathrm{H}, J=7.3 \mathrm{~Hz}, 4^{\prime}-\mathrm{H}\right)$, 7.36-7.39(overlapping multiplets, $\left.4 \mathrm{H}: 3^{\prime}, 5^{\prime}, 3^{\prime \prime}, 5^{\prime \prime}-\mathrm{H}\right), 7.43(\mathrm{~d}, 2 \mathrm{H}$, $J=7.3 \mathrm{~Hz}, 2^{\prime}-\mathrm{H}$ and $\left.6^{\prime}-\mathrm{H}\right), 7.82\left(\mathrm{~d}, 2 \mathrm{H}, J=8.2 \mathrm{~Hz}, 2^{\prime \prime}-\mathrm{H}\right.$ and $\left.6^{\prime \prime}-\mathrm{H}\right)$, ${ }^{13} \mathrm{C}$ NMR $\delta$ ppm 15.7 and 21.4: C-18 and Ts-Me, 25.7, 27.1, 30.1, 32.4, 35.6. 37.9(C-13), 40.7, 42.8, 43.8, 69.7 $\left(\mathrm{OCH}_{2}\right), 76.5(\mathrm{C}-17)$, 112.2(C-2), 114.2(C-4), 114.5(C-16a), 126.1 and $127.2(2 \mathrm{C})$ and 127.6 and $127.7(2 \mathrm{C})$ and $128.3(2 \mathrm{C})$ : C-1, $2^{\prime}, 3^{\prime}, 4^{\prime}, 5^{\prime}, 6^{\prime}, 2^{\prime \prime}, 6^{\prime \prime}$, 129.5(2C: C-3", $\left.5^{\prime \prime}\right), 132.4(C-10), 132.7\left(C-1^{\prime \prime}\right), 137.0\left(C-1^{\prime}\right), 137.6(C-$ 5), 138.9(C-16), 144.4(C-4"), 156.5(C-3). MS m/z (\%): 530 (100), $552(45)$.

\subsection{Antiproliferative (MTT) assay}

The growth-inhibitory effects of the test compounds were determined on HeLa, MCF-7, A2780, Ishikawa and A431 cells isolated from cervical, breast, ovarian, endometrial and skin cancer, respectively. These cell lines were obtained from the European Collection of Cell Cultures, Salisbury, UK. The cells were cultivated in minimal essential medium (Sigma-Aldrich, Budapest, Hungary) supplemented with $10 \%$ fetal bovine serum, $1 \%$ non-essential amino acids and an antibiotic-antimycotic mixture. All media and supplements were obtained from Life Technologies (Paisley, Scotland, UK). All cell types were seeded into 96-well plates at a density of 5000 cells/well and incubated with increasing concentrations $(0.1-30 \mu \mathrm{M})$ of the compounds at $37^{\circ} \mathrm{C}$ under cell culturing conditions. After a 72-h incubation, cells were treated with $5.0 \mathrm{mg} / \mathrm{ml}$ MTT [3-(4,5-dimethylthiazol-2-yl)-2,5-diphenyltetrazolium bromide] solution for $4 \mathrm{~h}$, the precipitated formazan crystals were dissolved in dimethyl sulfoxide, and the absorbance was read at $545 \mathrm{~nm}$ with a microplate reader; wells with untreated cells were utilized as controls [10]. Sigmoidal concentration-response curves were fitted to the measured points, and the $\mathrm{IC}_{50}$ values were calculated by means of GraphPad Prism 4 (GraphPad Software, San Diego, CA, USA). Cisplatin was used as a positive control in the same concentration range as the test compounds.

To determine the selective cytotoxic effect, compound $\mathbf{6}$ was subjected to the MTT assay with intact, noncancerous, human foreskin cells under the same experimental conditions.

\subsection{Tubulin polymerization assay}

The effect of 3-benzyloxy-D-secoalcohol (6) on tubulin polymerization was tested with the Tubulin Polymerization Assay Kit (Tebu-bio, Le Perray-en-Yvelines, France) according to the manufacturer's recommendations. Briefly, $10 \mu \mathrm{l}$ of a 0.1 or $0.2 \mathrm{mM}$ solution of the test compound $(6)$ was placed on a prewarmed $\left(37^{\circ} \mathrm{C}\right)$, UV-transparent microplate. $10 \mu \mathrm{l} 10 \mu \mathrm{M}$ paclitaxel and $10 \mu \mathrm{l} \mathrm{Gen-}$ eral Tubulin Buffer were used as positive and negative control, respectively. $100 \mu \mathrm{l} 3.0 \mathrm{mg} / \mathrm{ml}$ tubulin in $80 \mathrm{mM}$ PIPES $\mathrm{pH} 6.9$, $2 \mathrm{mM} \mathrm{MgCl}$, 0.5 mM EGTA, 1 mM GTP, 10.2\% glycerol was added to each sample, and the microplate was immediately placed into a prewarmed $\left(37^{\circ} \mathrm{C}\right.$ ) UV-spectrophotometer (SpectoStarNano, BMG Labtech, Ortenberg, Germany) to start the recording reaction. A 60-min kinetic measurement protocol was applied to determine the absorbance of the reaction solution per minute at $340 \mathrm{~nm}$. For evaluation of the experimental data, a tubulin polymerization curve was used in which optical density was plotted against time, and the maximum reaction rate $\left(V_{\max }: \Delta\right.$ absorbance/min) was calculated. Differences between absorbances determined at two consecutive timepoints were calculated and the highest difference was taken as the $V_{\max }$ of the tested compound in the tubulin polymerization reaction. Each sample was prepared in two parallels. For statistical evaluation, $V_{\max }$ data were analyzed by the unpaired Student's $t$-test by using Prism 4 software. The $V_{\max }$ values of the tested compounds were compared with the rate of the basal tubulin polymerization (i.e. the untreated control).

\subsection{Docking calculations}

Docking calculations were carried out according to the DockingServer methodology [11]. The MMFF94 force field [12] was used for energy minimization of the ligand molecule by using DockingServer. PM6 semiempirical charges calculated by MOPAC2009 [13] were ascribed to the ligand atoms. Nonpolar hydrogen atoms were merged, and rotatable bonds were defined.

Docking calculations were carried out on the tubulin structure with the pdb code 1Z2B. Essential hydrogen atoms, Kollman united atom type charges and solvation parameters were added with the aid of AutoDock tools [14]. Affinity (grid) maps of $25 \times 25 \times 25 \AA$ grid points and $0.375 \AA$ spacing were generated by using the Autogrid program [14]. The simulation box center was set to the center of the crystallized ligand. AutoDock parameter set- and distancedependent dielectric functions were used in the calculation of the van der Waals and the electrostatic terms, respectively.

Docking simulations were performed by using the Lamarckian genetic algorithm and the Solis \& Wets local search method [15]. The initial positions, orientations and torsions of the ligand molecules were set randomly. Each docking experiment involved 50 different runs that were set to terminate after a maximum of $2.5 \times 10^{6}$ energy evaluations. The population size was set to 150 . During the search, a translational step of $0.2 \AA$ and quaternion and torsion steps of 5 were applied.

\section{Results and discussion}

\subsection{Synthesis of D-homo- and D-secoestrones}

The literature reveals several synthetic approaches for the formation of $\mathrm{D}$ homologs of estrone. The total synthesis of $\mathrm{D}$-homoestrone (4) was first reported by Ananchenko et al. [16]. Semisynthetic methods, and particularly the ring expansion of fivemembered ring D of estrone analogs, are complex, multistep reactions and therefore exhibit low efficiency [17]. We recently developed an efficient route for the synthesis of D-homoestrone (4) from a $\delta$-alkenyl-D-secoestrone-3-benzyl ether $(\mathbf{1})$, which is available in several steps from estrone 3-benzyl ether via a Grob fragmentation as key step $[6,18]$. In the present work we used the D-secoaldehyde (1) for the synthesis of D-homoestradiol (5), as the impact of $\mathbf{5}$ on the proliferation of the human cancer cell lines HeLa, MCF-7, A2780, Ishikawa and A430 does not appear to have been described in the literature. The intramolecular Prins cyclization of 1 with 1.1 equivalents of $p$-toluenesulfonic acid and the subsequent Jones oxidation (and simultaneous $\beta$-elimination of the tosyloxy group) led to the desired $\alpha, \beta$-unsaturated ketone (2, Scheme 1). The hydride reduction of $\mathbf{2}$ selectively yielded its 17a $\beta$-hydroxy 
derivative (3). During the hydrogenation of $\mathbf{2}$, hydrogenolysis of the 3-benzyl group and saturation of the 16,17-double bond occurred, leading to D-homoestrone (4), hydride reduction of which selectively yielded $17 a \beta$-hydroxy-D-homoestradiol (5).

Hydride reduction of the D-secoaldehyde (1) with potassium borohydride or the oxidation of $\mathbf{1}$ with Jones reagent ( $8 \mathrm{~N}$ ) was carried out in order to obtain the 3-benzyloxy-D-secoalcohol (6) and the 3-benzyloxy-D-secocarboxylic acid (7), which can be used as starting materials for electrophile-induced ring-closure reactions (Scheme 2). Jones oxidation of the aldehyde function in $\mathbf{1}$ was accompanied by the formation of a bridged lactone $\mathbf{8}$, similarly as described earlier [7]. It was previously shown that the secoaldehyde in the 3-methoxy $13 \beta$-estrone and $13 \alpha$-estrone series readily cyclizes and furnishes 17-oxa-D-homo-tetrahydropyrans or 17-oxa-D-homo- $\delta$-lactones (NBS or $\mathrm{I}_{2}$ were used as electrophile triggers). In the present work, we carried out halo- or selenoetherification and halo- or selenolactonization reactions to obtain 16-halomethyl- or 16-phenylselenylmethyl-substituted 17-oxa-Dhomo-3-benzyl ethers. Bromoetherification of $\mathbf{6}$ with an equimolar amount of NBS in MeCN afforded 9a (Scheme 1, Table 1, Entry (1). The reaction was carried out at $-15{ }^{\circ} \mathrm{C}$ to avoid the formation of 2 bromo derivatives by electrophile substitution. A 2:1 diastereomeric ratio was observed in the iodoetherification with iodine, yielding a mixture of $\mathbf{9 b}$ and $\mathbf{1 0 b}$ (Table 1, Entry (2). The application of phenylselenyl bromide as electrophile trigger led to a different isomeric ratio $(\mathbf{9} \mathbf{c}+\mathbf{1 0 c}=1: 1$, Table 1, Entry (3). The configuration at C-16 in the tetrahydropyrans $\mathbf{1 0}$ was established from NOESY experiments, which demonstrated a crosspeak between the multiplet of $16-\mathrm{H}$ and the singlet of the angular methyl group. The orientation of the 16a substituent in the minor diastereomers (10) is therefore the opposite $(\alpha)$ of that of the angular methyl group. The electrophile-induced cyclizations of the secocarboxylic acid $\mathbf{7}$ furnished one diastereomer $\mathbf{1 1}$ stereoselectively (Table 1, Entries 4-6). NOESY experiments revealed the $\beta$ position for the 16 substituent. These results are in good agreement with the earlier observations in the 3-methoxy series [7].

For functionalization of the alcoholic and phenolic hydroxy groups in the secoalcohol 6 (Fig. 1, Table 2), esterification was carried out by using acetic anhydride under microwave irradiation on a solid support, since microwave heating is a very effective and non-polluting method of activation. Irradiation under solvent-free conditions usually leads to higher conversions and shorter reaction times and has several environmental advantages (green chemistry) [19]. 6 was subjected to hydrogenolysis in order to remove the benzyl protecting group and to saturate the alkenyl side-chain (Table 2, Entry 1). The resulting diol 12a was acetylated with acetic anhydride on a silica gel support in a microwave reactor, yielding 12b (Table 2, Entry 2 ). The partially acetylated 12c was synthetized

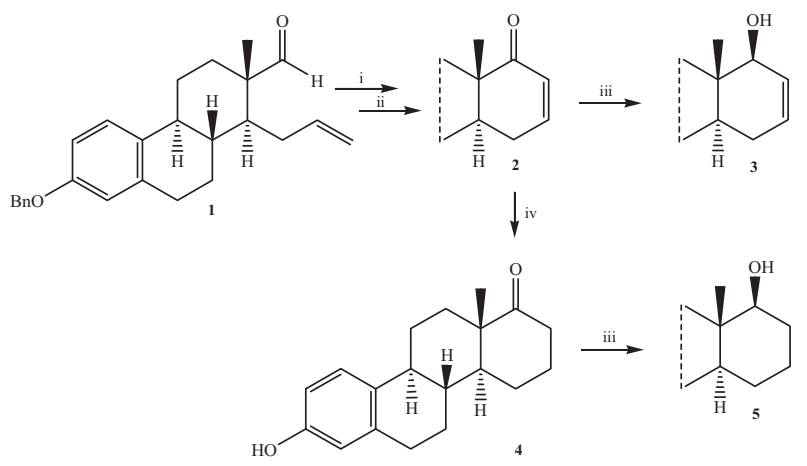

Scheme 1. Reagents and conditions: (i) $p$ - $\mathrm{TsOH}, \mathrm{CH}_{2} \mathrm{Cl}_{2}, 0{ }^{\circ} \mathrm{C}-$ r.t., $24 \mathrm{~h}$; (ii) Jones reagent $\left(8 \mathrm{~N}\right.$ ), $\mathrm{Me}_{2} \mathrm{CO}, 0^{\circ} \mathrm{C}, 1 \mathrm{~h}$; (iii) $\mathrm{KBH}_{4}, \mathrm{MeOH}, 0^{\circ} \mathrm{C}$ - r.t., 3 h; (iv) $\mathrm{H}_{2}$ (20 bar), Pd/ C, EtOAc, $24 \mathrm{~h}$. from the secoalcohol 6 by microwave-induced acetylation (Table 2 , Entry 3). Removal of the benzyl ether group from $12 \mathrm{c}$ led to $\mathbf{1 2 d}$ (Table 2, Entry 4). Tosylation of 6 furnished 12e (Table 2, Entry 5).

\subsection{Determination of antiproliferative properties of the newly synthetized compounds (6-12) and the effect of secoalcohol 6 on tubulin polymerization}

Microtubuli are polymers of tubulin, which in turn is a dimer involving an $\alpha$ unit and a $\beta$ unit. They have a wide range of biological functions, including maintenance of the cytoskeleton and the organization of intracellular transport, but the formation of mitotic spindles is generally regarded as the most relevant and is the most intensively investigated aspect [20]. A variety of cytotoxic agents such as colchicine, vinca alkaloids, taxans, combrestatin and 2methoxyestradiol (2ME) influence the equilibrium between the polymerization and degradation of the microtubuli, and are therefore able to influence cell division in a cell cycle phase-specific manner [21]. It has recently been established that some agents that interact with tubulin are also able to target the vascular system of tumors [22], causing vasculature recession or vasculature 'normalization' [23]. 2ME, a well-known nonpolar endogenous metabolite of $17 \beta$-estradiol, is a potent antiproliferative, apoptotic and antiangiogenic agent in vitro and in vivo at pharmacological concentrations [24]. Investigation of its antitumor activity on different malignancies in clinical studies revealed that $2 \mathrm{ME}$ can be tolerated up to very high doses (e.g. $1200 \mathrm{mg}$ /day) [25,26]. The most important mechanisms of its action seem to be the inhibition of neoangiogenesis, microtubule disruption and the upregulation of factors regulating extrinsic and intrinsic apoptotic pathways [27]. Cushman et al. reported that 2-ethoxyestradiol is a more potent cytotoxic agent than $2 \mathrm{ME}$ in cancer cell cultures, and is also a tubulin polymerization inhibitor [28]. Hillisch et al. patented the finding that some D-homoestra-1,3,5(10)-trien-3-yl 2-substituted sulfamates are potential pharmaceuticals for the treatment of tumorous diseases [4] by acting as tubulin polymerization inhibitors. We recently characterized the antitumor activities of 13-epimers of D-homoestrone and their 3-methyl ether counterparts on HeLa, MCF-7 and Ishikawa cells, providing the first evidence that D-homoestrone selectively suppresses HeLa cell proliferation and modulates cell cycle progression, leading to the accumulation of cells in the G2/M phase. Moreover, no significant in vivo estrogenic activity was observed as concerns the weight gain of the uterine tissue of gonadectomized rats after a 7-day treatment with Dhomoestrone. The 3-methyl ether and 13-epi counterparts did not display any effect on the proliferation of the tested cells [5].

In the present study, we tested D-homoestrone derivatives that are readily available via the D-homoestrone synthetic pathway [5]. Compounds 2-5 differ only in the functional groups on C-3 and C$17 \mathrm{a}$, and possess no other substituents. In vitro antiproliferative tests were carried out on a panel of human adherent cancer cell lines (Table 3). Compounds $\mathbf{3}$ and $\mathbf{5}$ proved to exert substantial cell-line selective antiproliferative activities against ovarian and cervical cancer cell lines, respectively. 17a $\beta$-D-Homoestradiol (5) behaved similarly to D-homoestrone (4) [5]. The 3-benzyl ether of the unsaturated ketone $\mathbf{2}$ was not active. As concerns the results for 2-5 and D-homoestrone-3-methyl ether [5], three of the five tested 13 $\beta$-methyl-D-homoestrone derivatives are potent selective cytotoxic agents, acting in the low micromolar range. The nature of the protecting group at position 3 has a great influence on the antiproliferative properties.

Möller et al. found that some 2- and/or 16-halogenated Dhomoestrone derivatives are efficient inhibitors of $17 \beta$-hydroxysteroid dehydrogenase type 1 , and their binding affinity to human estrogen receptor $\alpha$ is reduced by 100 - to 1000 -fold relative to that of estradiol [29]. Accordingly, such modified D-homoestrone 


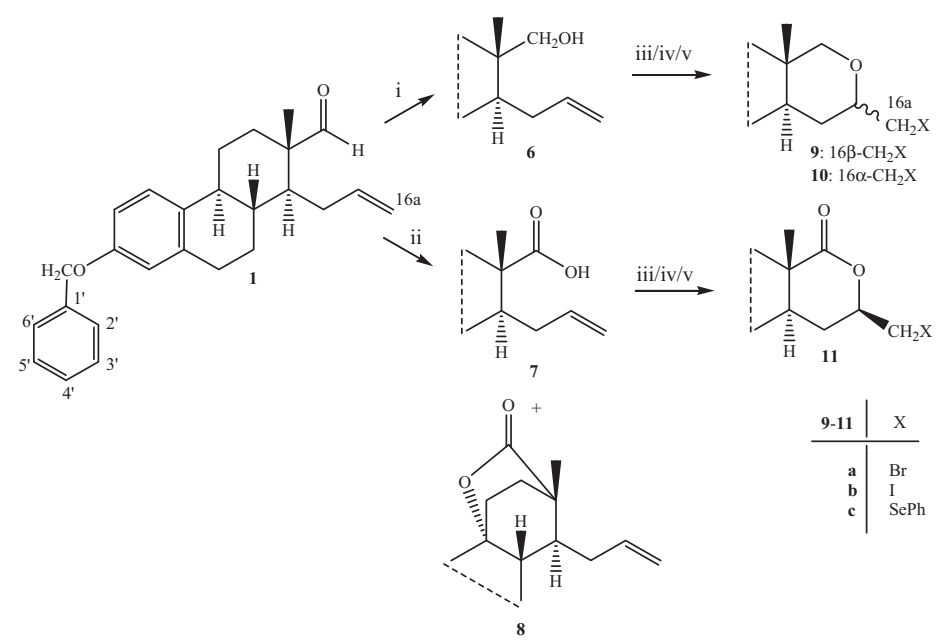

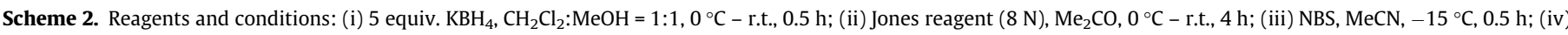
$\mathrm{I}_{2}, \mathrm{NaHCO}_{3}, \mathrm{CH}_{2} \mathrm{Cl}_{2} / \mathrm{THF}$, r.t., 1 h; (v) PhSeBr, MeCN, r.t., 1 h.

Table 1

Synthesis of D-homoestrone derivatives (9-11).

\begin{tabular}{lllll}
\hline Entry & Starting secosteroid & Electrophilic reagent & Product & Yield (\%) \\
\hline 1 & $\mathbf{6}$ & NBS & $\mathbf{9 a}$ & 68 \\
2 & $\mathbf{6}$ & NIS & $\mathbf{9 b}+\mathbf{1 0 b}$ & $50+25$ \\
3 & $\mathbf{6}$ & PhSeBr & $\mathbf{9 c}+\mathbf{1 0 c}$ & $36+36$ \\
4 & $\mathbf{7}$ & NBS & $\mathbf{1 1 a}$ & 82 \\
5 & $\mathbf{7}$ & NIS & $\mathbf{1 1 b}$ & 84 \\
6 & $\mathbf{7}$ & PhSeBr & $\mathbf{1 1 c}$ & 79
\end{tabular}

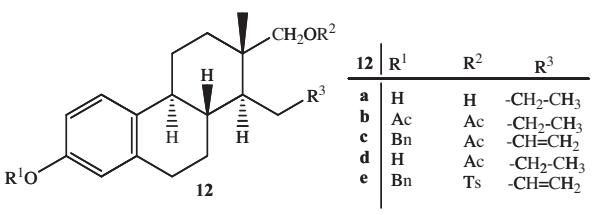

Fig. 1. The synthetized D-secoestrone derivatives.

Table 2

Synthesis of D-secoestrone derivatives (12).

\begin{tabular}{lcllll}
\hline Entry & Substrate & Reagent & Reaction conditions & Product & Yield (\%) \\
\hline 1 & $\mathbf{6}$ & $\mathrm{H}_{2}, \mathrm{Pd} / \mathrm{C}$ & $10 \mathrm{bar}, \mathrm{rt}$ & $\mathbf{1 2 a}$ & 87 \\
2 & $\mathbf{1 2 a}$ & $\mathrm{Ac}_{2} \mathrm{O}$ & $\mathrm{MW}, 5 \mathrm{~min}, 160^{\circ} \mathrm{C}$ & $\mathbf{1 2 b}$ & 86 \\
3 & $\mathbf{6}$ & $\mathrm{Ac}_{2} \mathrm{O}$ & $\mathrm{MW}, 5 \mathrm{~min}, 160^{\circ} \mathrm{C}$ & $\mathbf{1 2 c}$ & 91 \\
4 & $\mathbf{1 2 c}$ & $\mathrm{H}_{2}, \mathrm{Pd} / \mathrm{C}$ & $10 \mathrm{bar}, \mathrm{rt}$ & $\mathbf{1 2 d}$ & 88 \\
5 & $\mathbf{6}$ & $\mathrm{TsCl}$ & $3 \mathrm{~h}, \mathrm{rt}$ & $\mathbf{1 2 e}$ & 95
\end{tabular}

derivatives may be used for the treatment of estradiol-dependent diseases. Those previous results led us to examine the antiproliferative properties of the synthetized halogen-containing D-homoestrones. The 16-halomethyl-17-oxa-D-homosteroids (9-11) and their starting compounds $(\mathbf{6}, \mathbf{7})$ were tested in vitro. None of the 16-halomethyl derivatives influenced the proliferation of the tested tumor cells, but the secoalcohol $(6)$ proved to be effective against all the cell lines, and especially on the estrogen receptorpositive breast adenocarcinoma (MCF-7), skin epidermoid (A431) and endometrial (Ishikawa) carcinoma cells $\left(\mathrm{IC}_{50}=5-8 \mu \mathrm{M}\right)$. Structural modifications of secoalcohol $\mathbf{6}$ at three sites in the molecule yielded diverse derivatives (12) which displayed different effects on the proliferation of the cell lines. Acetylation of the 17$\mathrm{OH}$ group led to the 17-acetoxy-3-benzyl ether (12c) which exhibited similar antiproliferative action to that of its 17-hydroxy
Table 3

Antiproliferative properties of the synthetized compounds.

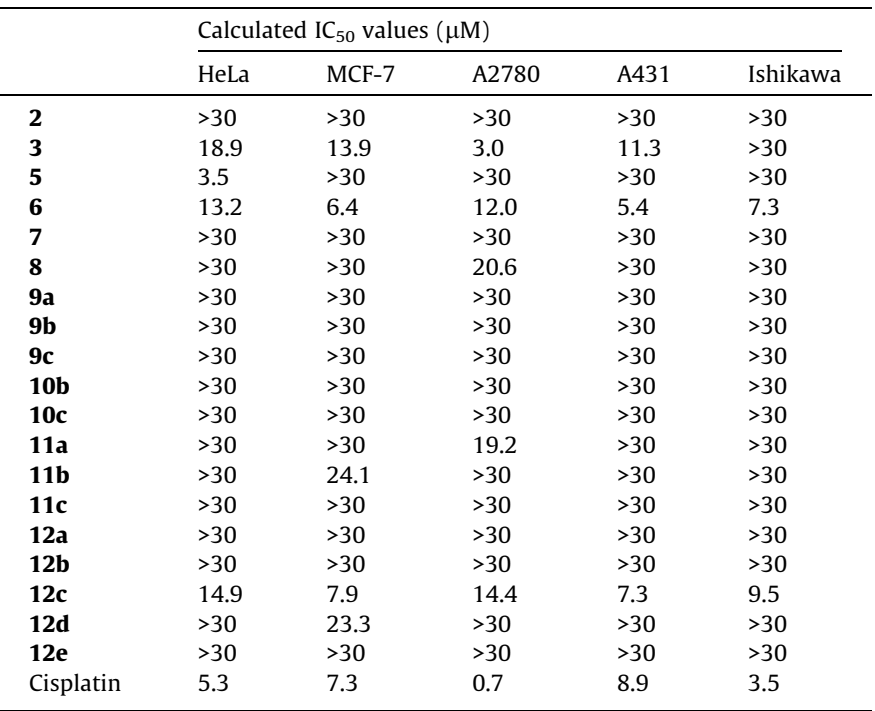

* Mean values from two independent determinations with five parallel wells standard deviation $<15 \%$.

counterpart (6), whereas the 17-tosyl ester (12d) appeared to be inactive. Removal of the 3-benzyl protecting group and simultaneous saturation of the propenyl side-chain furnished 12a, which demonstrated complete loss of the growth-inhibitory behavior, and the 16-acetoxy-3-ol (12d) and the 3,17-diacetate (12b) were also totally inactive. The results of the MTT assays for the secoestrones $\mathbf{6}$ and $\mathbf{1 2}$ indicate that the benzyl ether protecting group is necessary for the antiproliferative activity, which is greatly affected by the nature of the 17-functional group.

We are not aware of literature reports of effective antitumor D-secoestrone derivatives against the HeLa, MCF-7, A2780, A431 and Ishikawa cell lines. Saloranta et al. described 17-homoallylic D-secoestrones with low antitumor potentials on these cell lines $\left(\mathrm{IC}_{50}>30 \mu \mathrm{M}\right)$ [30]. D-Secoestrone nitriles were recently tested in vivo for estrogenic activity. Opening of ring D resulted in complete loss of the estrogenic activity, whereas some derivatives exerted moderate antiestrogenic effects [31-33]. As D-secoestrone derivative 6 suppresses the proliferation of MCF-7, A431 and Ishikawa cells, it was selected for additional in vitro experiments. 
Table 4

Proliferation-inhibitory effects of compound $\mathbf{6}$ and cisplatin on noncancerous human foreskin fibroblast cells, determined in the 72-h antiproliferative assay described in Section 2.2.

\begin{tabular}{lcc}
\hline Compound & $\begin{array}{l}\text { Applied concentration } \\
(\mu \mathrm{M})\end{array}$ & $\begin{array}{l}\text { \% Inhibition of } \\
\text { proliferation } \pm \mathrm{SEM}^{*}\end{array}$ \\
\hline $\mathbf{6}$ & 3.0 & $8.3 \pm 1.2$ \\
& 10.0 & $17.7 \pm 2.1$ \\
Cisplatin & 3.0 & $12.5 \pm 1.7$ \\
& 10.0 & $22.1 \pm 4.6$ \\
\hline
\end{tabular}

Mean values from two independent determinations with five parallel wells.

Since tumor specificity is one of the greatest challenges facing new anticancer drug candidates, this feature was additionally investigated for $\mathbf{6}$. When intact, noncancerous human foreskin fibroblast cells were incubated with 3.0 or $10 \mu \mathrm{M} 6$ for $72 \mathrm{~h}$, a weak proliferation-inhibiting effect ( $8.3 \%$ and $17.7 \%$ inhibition, respectively) was detected (Table 4). Cisplatin, our positive control molecule, elicited similar inhibitory activity on fibroblast cell proliferation at these concentrations. Although the tumor specificity of secoestrone $\mathbf{6}$ does not differ significantly from that of cisplatin, a compound generally used in the therapy of cancerous diseases of female reproductive organs, it may be noted that to date there have been no reports of the tumor specificity of D-secoestrone derivatives with potent antitumor activity.
Various cytotoxic estrones behave as tubulin polymerization inhibitors [3,29,34,35], and there is evidence relating to a B-homoestrone derivative which enhances tubulin assembly and stabilizes microtubules similarly to paclitaxel [36]. However, no information was previously available on the impact of D-secoestrones on tubulin polymerization. We present here data on the effect of a D-secoalcohol (6) on the kinetics of in vitro tubulin polymerization. Our test compound (6) significantly enhanced the maximum rate $\left(V_{\max }\right)$ of formation of microtubules (Fig. 2).

This significant increase in $V_{\max }$ might be due to the interaction of compound $\mathbf{6}$ with the colchicine binding site of tubulin, as previously reported for several estrone analogs [36]. To determine whether compound $\mathbf{6}$ interacts with tubulin, it was docked into both the colchicine and the vinblastine binding sites of tubulin. Molecular docking calculations were carried out using the available crystal structure of tubulin crystallized with both colchicine and vinblastine (PDB code: 1Z2B) [37]. The results revealed that both the interaction energy and the frequency of docking suggest more favorable binding of the ligand at the colchicine binding site. The interactions of the ligand at the binding site are presented in Fig. 3. Compound $\mathbf{6}$ is seen to be stabilized mainly by hydrophobic interactions between the hydrophobic amino acids at the binding site and the hydrophobic ring of the ligand: LEU-248, ALA-250, LEU-255, ALA-316, VAL-315 and MET-299 in the B chain and VAL-181 in the A chain are within interacting distance. The
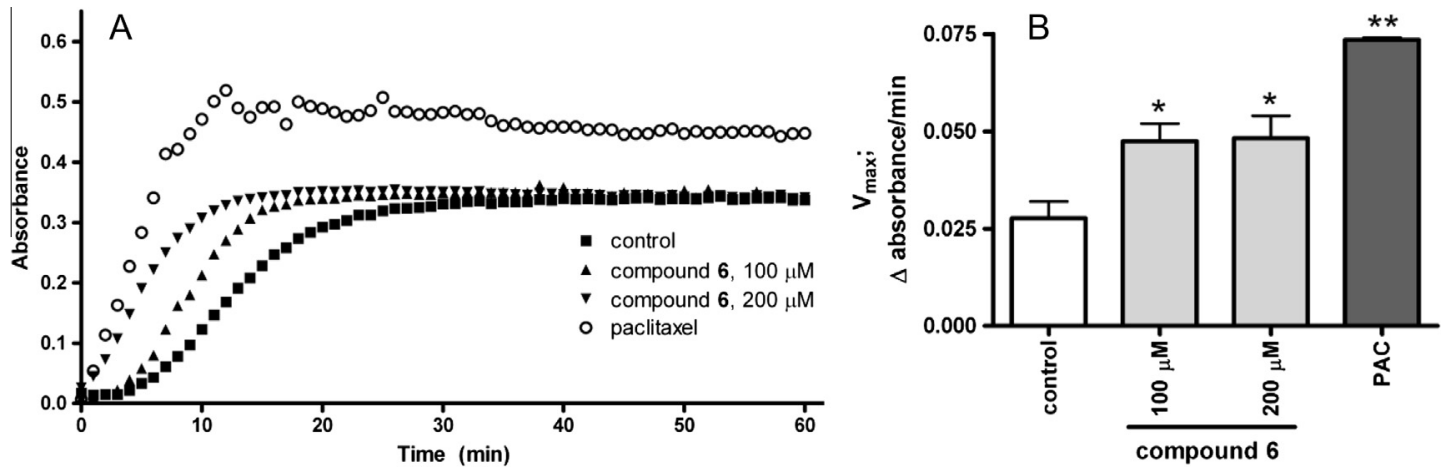

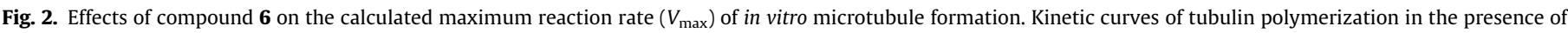

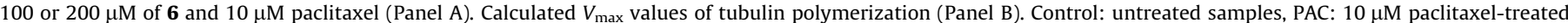

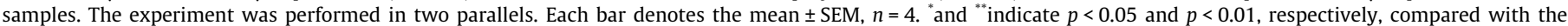
control values.

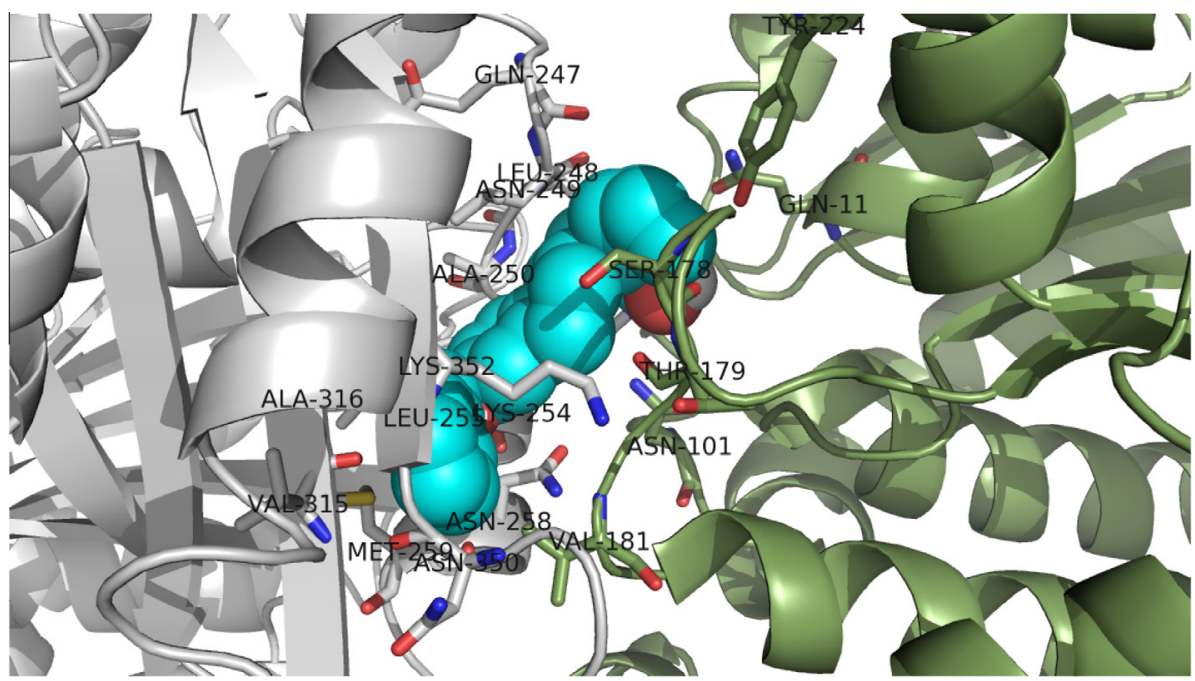

Fig. 3. Interactions of ligand $\mathbf{6}$ at the colchicine binding site of tubulin. 
alcoholic oxygen of the ligand accepts a hydrogen-bond from the amide nitrogen of ASN101 in the A chain, whereas the oxygen is donated to GLN11 in the A chain.

\section{Acknowledgments}

The authors thank the Hungarian Scientific Research Fund (OTKA K101659 and K109293), the New Hungary Development Plan (TÁMOP-4.2.2.A-11/1/KONV-2012-0047) and the Richter Gedeon Plc. for financial support. This research was supported by the European Union and the State of Hungary, co-financed by the European Social Fund in the framework of TÁMOP 4.2.4. A/2-111-2012-0001 'National Excellence Program'.

\section{References}

[1] Dickson RB. Stancel GM Estrogen-receptor mediated processes in normal and cancer cells. J Natl Cancer Inst Monographs 2000;27:135-45.

[2] Mueck AO, Seeger H. 2-Methoxyestradiol - biology and mechanism of action. Steroids 2010;75:625-31

[3] Gupta A, Kumar SB, Negi AS. Currents status on development of steroids as anticancer agents. J Steroid Biochem Mol Biol 2013;137:242-70.

[4] Hillisch A, Peters O, Gege C, Siemeister G, Unger E, Menzenbach B. Antitumoral D-homoestra-1,3,5(10)-trien-3-yl 2-substituted sulfamates. 2011, US RE42,132 E.

[5] Minorics R, Bózsity N, Wölfling J, Mernyák E, Schneider Gy, Márki Á, Falkay G, Ocsovszki I, Zupkó I. Antiproliferative effect of normal and 13-epi-Dhomoestrone and their 3-methyl ethers on human reproductive cancer cell lines. J Steroid Biochem Mol Biol 2012;132:168-74.

[6] Wölfling J, Mernyák E, Frank É, Falkay G, Márki Á, Minorics R, Schneider G. Synthesis and receptor-binding examinations of the normal and 13-epi-Dhomoestrones and their 3-methyl ethers. Steroids 2003;68:277-88.

[7] Frank É, Mernyák E, Wölfling J, Schneider Gy. Stereoselective approach to some novel 16-methylated and 16-halomethylated tetrahydropyran and $\delta$-lactone derivatives in both the normal and the $13 \alpha$-estrone series. Synlett 2002:1803-6.

[8] Tietze LF, Schneider Gy, Wölfling J, Fecher A, Nöbel T, Petersen S, Schuberth I, Wulff C. A novel approach in drug discovery: synthesis of estrone-talaromycin natural product hybrids. Chem Eur J 2000;6:3755-60.

[9] Sorokina IB, Barkova TI, Zakharychev AA, Chigir RN, Ananchenko SN, Torgov IV. Estrogen and antineoplastic activity in a series of transformed estrone and estradiol analogs. Izv Akad Nauk SSSR, Ser Biol 1973;5:664-70.

[10] Wang Z, Yang D, Mohanakrishnan AK, Fanwick PE, Nampoothiri P, Hamel E, Cushman M. Synthesis of B-ring homologated estradiol analogues that modulate tubulin polymerization and microtubule stability. J Med Chem 2000;43:2419-29.

[11] Bikadi Z, Hazai E. Application of the PMa semi-empirical method to modelling proteins enhances docking accuracy of AutoDock. J Cheminf 2009;1:15.

[12] Halgren TA. Merck molecular force field. I. Basis, form, scope, parametrization and performance of MMFF94. J Comp Chem 1998;17:490-519.

[13] Stewart JP. Computer code MOPAC2009, Stewart Computational Chemistry; 2009.

[14] Morris GM, Goodsell DS, Halliday RS, Huey R, Hart WE, Belew RK, Olson AJ. Automated docking using a Lamarckian genetic algorithm and an empirical binding free energy function. J Comp Chem 1998;19:1639-62.

[15] Solis FJ, Wets RJB. Minimization by random search techniques. Math Operat Res 1981;6:19-30.

[16] Ananchenko SN, Limanov VY, Leonov VN, Rzheznikov VN, Torgov IV. Syntheses of derivatives of oestrane and 19-norsteroids from 6-methoxytetralone and 6hydroxytetralone. Tetrahedron 1962;18:1355-67.
[17] Bull JR, Steer LM. Intramolecular condensation of steroidal $17 \alpha$-formyl-17 $\beta$ acetates: model studies on 19-norsteroids, and a route to 3-methoxy-19-nor17 $\alpha$-pregna-1,3,5(10)-triene-21,17-carbolactone. Tetrahedron 1990;46: 5389-400.

[18] Schneider G, Bottka S, Hackler L, Wölfling J, Sohár P. Neighbouring group participation and fragmentation during the solvolysis of the epimers of 3methoxy-16-(tolylsulfonyloxymethyl)-estra-1,3,5(10)-triene-17-ol. Liebigs Ann Chem 1989:263-7.

[19] Bougrin K, Loupy A, Soufiaoui M. Microwave-assisted solvent-free heterocyclic synthesis. J Photochem Photobiol C 2005;6:139-67.

[20] Lin YM, Chen HL, Lee HY, Lion JP. Tubulin inhibitors: a patent review. Expert Opin Ther Pat 2014;24:69-88.

[21] Campos SM, Dizon DS. Antimitotic Inhibitors. Hematol Oncol Clin N Am 2012;26:607-28.

[22] Thorpe PE, Chaplin DJ, Blakey DC. International conference on vascular targeting: meeting overview. Cancer Res 2003;63:1144-7.

[23] Jain RK. Normalization of tumor vasculature: an emerging concept in antiangiogenic therapy. Science 2005;307:58-62.

24] Han GZ, Liu ZJ, Shimoi K, Thing Zhu B. Synergism between the anticance actions of 2-methoxyestradiol and microtubule-disrupting agents in human breast cancer. Cancer Res 2005;65:387-93.

[25] Sweeney C, Liu G, Yiannoutsos C, Kolesar J, Horvath D, Staab MJ, Fife K Armstrong V, Treston A, Sidor C, Wilding G. A phase II multicenter, randomized, double-blind, safety trial assessing the pharmacokinetics, pharmacodynamics, and efficacy of oral 2-methoxyestradiol capsules in hormone-refractory prostate cancer. Clin Cancer Res 2005;11:6625-33.

[26] Dahut WL, Lakhani NJ, Gulley JL, Arlen PM, Kohn EC, Kotz H, McNally D, Parr A Nguyen D, Yang SX, Steinberg SM, Venitz J, Sparreboom A, Figg WD. Phase clinical trial of oral 2-methoxyestradiol, an antiangiogenic and apoptotic agent, in patients with solid tumors. Cancer Biol Ther 2006;5:22-7.

[27] Mooberry SL. New insights into 2-methoxyestradiol, a promising antiangiogenic and antitumor agent. Curr Opin Oncol 2003;15:425-30.

[28] Cushman M, He HM, Katzenellenbogen JA, Varma RK, Hamel E, Lin CM, Ram S, Sachdeva Y. Synthesis of Analogs of 2-methoxyestradiol with enhanced inhibitory effects on tubulin polymerization and cancer cell growth. J Med Chem 1997;40:2323-34.

[29] Möller G, Deluca D, Gege C, Rosinus A, Kowalik D, Peters O, Droescher P, Elge W, Adamski J, Hillisch A. Structure-based design, synthesis and in vitro characterization of potent 17 $\beta$-hydroxysteroid dehydrogenase type 1 inhibitors based on 2-substitutions of estrone and D-homo-estrone. Bioorg Med Chem Lett 2009;19:6740-4.

[30] Saloranta T, Zupkó I, Rakhila J, Schneider Gy, Wölfling J, Leino R. Increasing the amphiphilicity of an estradiol based steroid structure by Barbier-allylation ring-closing metathesis - dihydroxylation sequence. Steroids 2012;77:110-7.

[31] Jovanovic-Santa S, Andric S, Kovacevic R, Pejanovic V. Synthesis and biological activity of new 16,17-secoestrone derivatives. Coll Czech Chem Commun 2000;65:77-82.

[32] Petrovic JA, Stepic TZ, Pejanovic VM, Mijacevic L, Kovacevic R, Andric S, Stankovic SM. Synthesis and biological activity of two new D-secoestrone derivatives. J Serb Chem Soc 1998;63:113-6.

[33] Petrovic JA, Pejanovic VM, Miljkovic DA, Hranisavljevic JT. Synthesis and estrogen activity screening of some new D-secoestrone derivatives. Steroids 1990;55:276-8.

34] Wang M, Xu L, Gao M, Miller KD, Sledge GW, Zheng OH. Synthesis of 2 [11C]methoxy-3,17ß-00-bis(sulfamoyl)estradiol as a new potential PET agent for imaging of steroid sulfatase (STS) in cancers. Steroids 2012;77:864-70.

[35] Leese MP, Hejaz HAM, Mahon MF, Newman SP, Purohit A, Reed MJ, Potter BVL. A-ring-substituted estrogen-3-0-sulfamates: potent multitargeted anticancer agents. J Med Chem 2005;48:5243-56.

[36] Stander A, Joubert F, Joubert A. Docking, synthesis and in vivo evaluation of antimitotic estrone analogs. Chem Biol Drug Res 2011;77:173-81.

[37] Gigant B, Wang C, Ravelli RB, Roussi F, Steinmetz MO, Curmi PA, Sobel A Knossow M. Structural basis for the regulation of tubulin by vinblastine. Nature 2005;425:519-22. 
V. 


\title{
Antiproliferative effect of normal and 13-epi-D-homoestrone and their 3-methyl ethers on human reproductive cancer cell lines
}

\author{
Renáta Minorics ${ }^{\mathrm{a}}$, Noémi Bózsity ${ }^{\mathrm{a}}$, János Wölfling ${ }^{\mathrm{b}}$, Erzsébet Mernyák ${ }^{\mathrm{b}}$, Gyula Schneider ${ }^{\mathrm{b}}$, \\ Árpád Márki ${ }^{\mathrm{a}}$, George Falkay ${ }^{\mathrm{a}}$, Imre Ocsovszki ${ }^{\mathrm{c}}$, István Zupkó ${ }^{\mathrm{a}, *}$ \\ a Department of Pharmacodynamics and Biopharmacy, University of Szeged, H-6720 Szeged, Eötvös u. 6, Hungary \\ ${ }^{\mathrm{b}}$ Department of Organic Chemistry, University of Szeged, H-6720 Szeged, Dóm tér 8, Hungary \\ c Department of Biochemistry, University of Szeged, H-6720 Szeged, Dóm tér 9, Hungary
}

\section{A R T I C L E I N F O}

\section{Article history:}

Received 12 December 2011

Received in revised form 26 April 2012

Accepted 30 April 2012

\section{Keywords:}

Antiproliferative effect

D-Homoestrone

G2/M phase arrest

Apoptosis

Caspase-3 activity

In vivo estrogenic effect

\begin{abstract}
A B S T R A C T
The possibility of the therapeutic use of estrogens emerged following the recognition that certain estradiol analogs, and particularly metabolites (e.g. the A-ring metabolite 2-hydroxyestrone, etc.) inhibit the differentiation of diverse tumor cell lines. Until recently, despite the investigation of numerous synthetic D-ring-substituted estrone derivatives, no analysis had been published on the effects of D-ring expansion of estrone on its tumor-suppressing activity. The aim of the present study was to characterize the antiproliferative effects of normal and 13-epi-D-homoestrone and their 3-methyl ethers (1-4) on human reproductive cancer cell lines.

The antitumor activities of the two epimer pairs on HeLa, MCF-7 and Ishikawa cells were determined. Normal D-homoestrone exerted the greatest cytostatic effect on HeLa cells $\left(\mathrm{IC}_{50}=5.5 \mu \mathrm{M}\right)$ and was subjected to further investigations to elucidate its mechanism of action on apoptosis induction. Morphological changes detected by Hoechst 33258-propidium iodide double staining, the cell cycle arrest at phase G2/M and the subsequent increase in the proportion of the subG1 fraction determined by flow cytometric analysis and the significant increase in the activity of caspase- 3 confirmed the induction of apoptosis in HeLa cells treated with D-homoestrone. D-Homoestrone was also tested on a non-cancerous human lung fibroblast cell line (MRC-5) to determine its selective toxicity. The concentration in which it inhibited cell proliferation by $50 \%$ was at least six times higher for the fibroblast cells than for cervical cancer cells. No significant in vivo estrogenic activity was observed as concerns the uterus weight of gonadectomized rats after a 7-day treatment with normal D-homoestrone.

These results led to the conclusion that normal D-homoestrone is a novel antitumor compound with a similar activity on HeLa cells as that of the reference agent cisplatin, but its selectivity toward noncancerous cells is significantly higher than that of cisplatin. It may be considered to be a basic lead molecule for the preclinical development of potential anticancer agents.
\end{abstract}

(c) 2012 Elsevier Ltd. All rights reserved.

\section{Introduction}

Although $17 \beta$-estradiol has been described as a proliferationinducing compound [1], recent experimental results indicated that certain of its analogs can exert potent antiproliferative effects without appreciable estrogenic activity. One of the most widely investigated compounds is an A-ring-modified metabolite of estrone, 2-methoxyestradiol [2], which exerts potent inhibitory effects on the proliferation of ovarian [3,4], cervical [5-7], endometrial [8] and breast cancer cell lines [3,9,10], among others. 2-Methoxyestradiol has a complex mechanism of action, because

\footnotetext{
* Corresponding author. Tel.: +36 62 545567; fax: +36 62545567.

E-mail address: zupko@pharm.u-szeged.hu (I. Zupkó).
}

various pathways have been proved to be involved, e.g. the inhibition of neoangiogenesis $[9,11,12]$, microtubule disruption $[3,13]$, cell cycle arrest $[8,14]$ and upregulation of the extrinsic and intrinsic apoptotic pathways $[7,15,16]$.

A tumor-suppressing effect has been observed in in vivo animal studies (e.g. on methylnitrosourea-induced mammary carcinoma in rats [17]), when no toxic side effects were registered. Clinical studies of the possible antitumor potency of 2-methoxyestradiol revealed good tolerability, but limited oral bioavailability and metabolic instability $[18,19]$. To overcome this difficulty, the carboxamide analog of 2-methoxyestradiol was synthetized, which possesses the beneficial features of 2-methoxyestradiol, but is metabolically more stable. However, this compound too may suffer limitations in therapeutic use: in a phase I study, neutropenia was observed at a dose of $550 \mathrm{mg} / \mathrm{m}^{2} /$ day [20]. 
<smiles>[R20]c1ccc2c(c1)CC[C@@H]1[C@@H]2CC[C@]2(C)C(=O)CCC[C@@H]12</smiles>

$$
\begin{array}{ll}
1 \mathrm{R}=\mathrm{H}, \mathrm{C} 13 \beta & 3 \mathrm{R}=\mathrm{CH}_{3}, \mathrm{C} 13 \beta \\
2 \mathrm{R}=\mathrm{H}, \mathrm{C} 13 \alpha & 4 \mathrm{R}=\mathrm{CH}_{3}, \mathrm{C} 13 \alpha
\end{array}
$$

Fig. 1. Chemical structures of normal D-homoestrone (1), 13-epi-D-homoestrone (2) and their 3-methyl ethers ( 3 and $\mathbf{4}$, respectively).

The metabolism of estrone can continue by another pathway, hydroxylation of the $\mathrm{D}$ ring, resulting in the formation of $16 \alpha-$ hydroxyestrone and estriol. Similarly to A-ring derivatives, these have minimal estrogen receptor binding affinity [21,22]. Various types of D-ring-modified estrone analogs have been synthetized and tested for possible inhibitory effects on cell proliferation [23-25], but these modifications were restricted to substitution with different functional groups at position 17 and dehydration at positions 14,15 and 16 .

Until recently, no experimental data had been published in connection with the effect of D-ring expansion and substitution on the antiproliferative activity of the estrone derivatives, although they might be expected not to exhibit appreciable estrogen receptor binding affinity and therefore no estrogenic activity in vivo. Wölfling et al. [26] reported the synthesis of normal and 13-epiD-homoestrone and their 3-methyl ethers, and results on their estrogen and progesterone receptor binding abilities. There is a difference of at least three orders of magnitude between the $K_{i}$ values of the D-ring-modified estrone analogs and the reference molecule, $17 \beta$-estradiol, which raised our interest concerning their possible antiproliferative effects. The epimer pairs of the compounds are available for investigation of the influence of the stereoselectivity of the molecules on their antitumor activity, thereby furnishing detailed data concerning the structure-activity relationships of the tested compounds. As concerns $17 \beta$-estradiol derivatives with no in vitro estrogenic activity, a question that frequently emerges is whether they can be transformed by liver metabolizing enzymes into new molecules able to bind to and transactivate the estrogen receptor, which might even lead to a reduction of the antiproliferative effect exerted by the parental compound.

The aim of the present study was to characterize the mechanism of antiproliferative action of these four D-ring-modified estrone analogs on various human reproductive cancer cell lines. The compound found most effective in the cell-growth inhibition assay was subjected to Hoechst dye 33258 (HO)-propidium iodide (PI) double staining, flow cytometry analysis and caspase- 3 activity measurement. Its selective cytotoxic activity was determined on the MRC-5 human fetal lung fibroblast cell line. The lack of its in vivo estrogenic activity was confirmed by means of in vivo uterotrophic assays performed on gonadectomized female rats.

\section{Materials and methods}

\subsection{Chemicals}

Normal (1) and 13-epi-D-homoestrone (2) and their 3-methyl ethers (3 and 4, respectively) were synthetized as described previously [26]. Their chemical structures are presented in Fig. 1. All other chemicals and kits, if otherwise not specified, were purchased from Sigma-Aldrich Ltd. (Budapest, Hungary).

\subsection{Cell cultures}

The HeLa human cervix epitheloid carcinoma, MCF-7 human breast adenocarcinoma, Ishikawa human endometrial adenocarcinoma and MRC-5 human lung fibroblast cell lines were purchased from ECACC (European Collection of Cell Cultures, Salisbury, UK). HeLa, MCF-7 and MRC-5 cells were grown in Dulbecco's Modified Eagle's Medium (DMEM) supplemented with 10\% heat-inactivated fetal calf serum (FCS), 1\% non-essential amino acids and 1\% penicillin-streptomycin in a humidified atmosphere containing $5 \% \mathrm{CO}_{2}$ at $37^{\circ} \mathrm{C}$. However, Ishikawa cells were grown in DMEM medium supplemented with $5 \%$ FCS, $1 \%$ non-essential amino acids, $5 \% 200 \mathrm{mM}$ glutamine and $1 \%$ penicillin-streptomycin in a humidified atmosphere containing $5 \% \mathrm{CO}_{2}$ at $37^{\circ} \mathrm{C}$. For culturing in steroid-depleted media, MCF-7 cells were maintained in phenol red-free DMEM containing 10\% charcoal dextran-treated FCS with the addition of $1 \%$ non-essential amino acids, $5 \% 200 \mathrm{mM}$ glutamine and $1 \%$ penicillin-streptomycin. All media and supplements were obtained from Life Technologies (Paisley, Scotland, UK). Cell counts were determined with a Z1 Coulter Particle Counter (Beckman Coulter Hungary Ltd., Budapest, Hungary). Cells in the near-confluent phase of growth were used in all the studies described below.

\subsection{Antiproliferative (MTT) assay}

The growth-inhibitory effects of the test compounds were determined on HeLa, MCF-7 and Ishikawa cells. All cell types were seeded into 96 -well plates at a density of 5000 cells/well and incubated with increasing concentrations $(0.3-30 \mu \mathrm{M})$ of the four compounds at $37^{\circ} \mathrm{C}$ under cell culturing conditions. After a $72-\mathrm{h}$ incubation, cells were treated with $5.0 \mathrm{mg} / \mathrm{ml}$ MTT (3-(4,5dimethylthiazol-2-yl)-2,5-diphenyltetrazolium bromide) solution for $4 \mathrm{~h}$, the precipitated formazan crystals were dissolved in dimethyl sulfoxide, and the absorbance was read at $545 \mathrm{~nm}$ with a microplate reader; wells with untreated cells were utilized as controls [27]. Sigmoidal dose-response curves were fitted to the measured points, and the $\mathrm{IC}_{50}$ values were calculated by means of GraphPad Prism 4 (GraphPad Software, San Diego, CA, USA). Cisplatin was used as a positive control in the same concentration range as the test compounds.

The subsequent analyses were carried out only with the most effective compound and the most sensitive cell type.

To determine the selective cytotoxic effect and the antiproliferative effect in steroid-depleted medium, 1 was subjected to the MTT assay with intact, non-cancerous MRC- 5 cells and MCF-7 cells growing in steroid-free medium, respectively, under the same experimental conditions.

\subsection{Hoechst 33258-propidium iodide (HOPI) double staining}

HOPI staining was performed as described earlier [28]. HeLa cells at a density of 3000-5000 cells/well were seeded in 96-well plates and exposed to increasing concentrations of $\mathbf{1}$ in quadruplicate for 24,48 or $72 \mathrm{~h}$. HO and PI were added directly to the cells to give final concentrations of 5 and $2 \mu \mathrm{g} / \mathrm{ml}$, respectively. After incubation for $60 \mathrm{~min}$ at $37^{\circ} \mathrm{C}$, cells were examined under a Nikon ECLIPSE TS100 fluorescence microscope (Nikon Instruments Europe B.V., Amstelveen, The Netherlands) equipped with appropriate filters for $\mathrm{HO}$ (excitation: $360 / 40 \mathrm{~nm}$ bandpass filter, emission: 460/50 nm bandpass filter and $400 \mathrm{~nm}$ dichromatic mirror) and PI (excitation: 500/20 nm bandpass filter, emission: $520 \mathrm{~nm}$ longpass filter and $515 \mathrm{~nm}$ dichromatic mirror). This method allows a distinction between early apoptosis and secondary necrosis. Cells were assessed on the basis of their morphology and the integrity of their membranes, which can readily be seen after PI staining. Cells were 

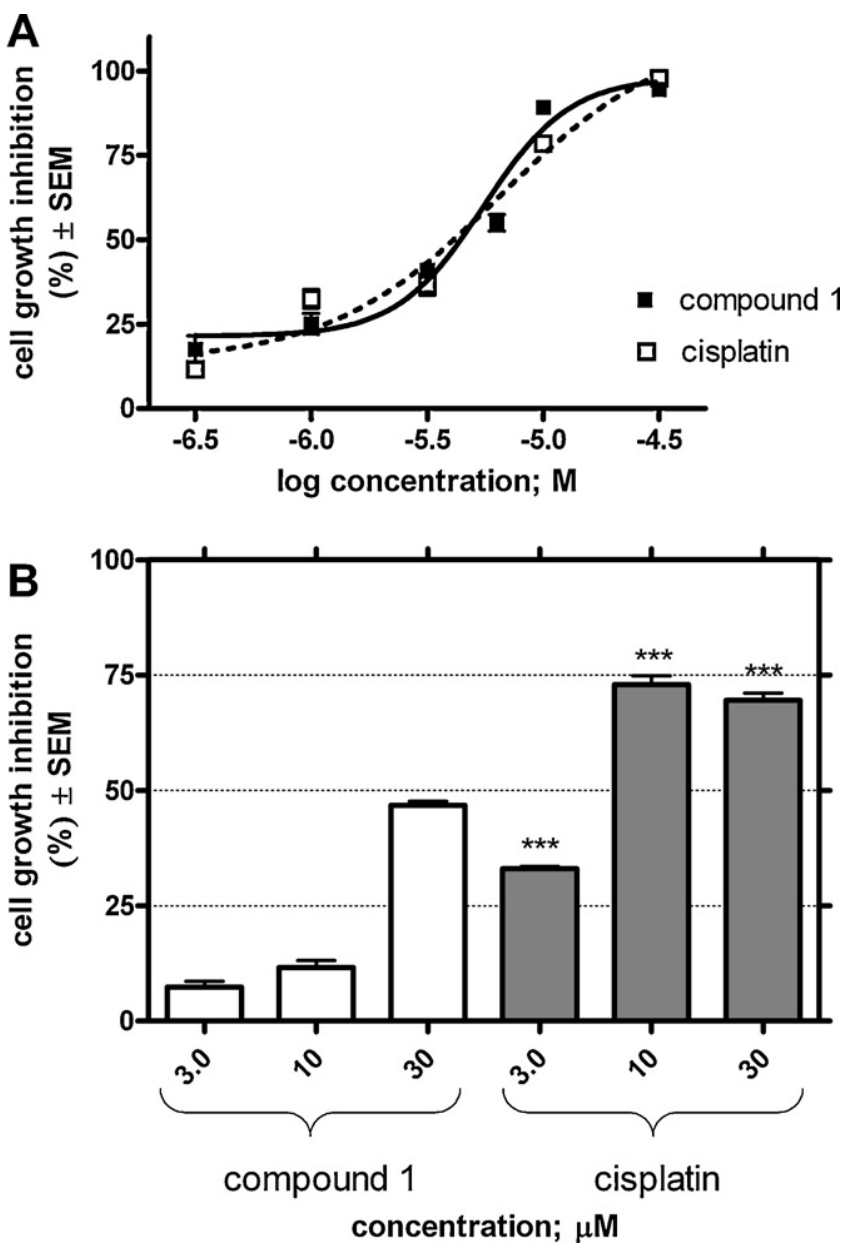

Fig. 2. The dose-response curves of compound 1 and cisplatin on HeLa cells, determined in the 72-h antiproliferative assay described in Section 2 (A). Proliferation-inhibitory effects of compound $\mathbf{1}$ and cisplatin on non-cancerous MRC5 cells, determined in the 72-h antiproliferative assay described in the Materials and methods (B). Each bar denotes the mean \pm SEM, $n=5$. *** indicates $p<0.001$ for the comparisons of the corresponding concentration pairs of compound $\mathbf{1}$ and cisplatin.

counted under the microscope (two fields of vision were captured in each well; $100-250$ cells were counted in each capture) and the percentages of intact, early apoptotic and secondary necrotic cells were calculated. For statistical evaluation, data were analyzed by one-way ANOVA with the Neumann-Keuls post test, using Prism 4 software.

\subsection{Analysis of apoptosis and cell cycle by flow cytometry}

For the measurement of cellular DNA content, flow cytometric analysis was performed: 24,48 and $72 \mathrm{~h}$ after treatment, HeLa cells (180,000-250,000 cells/condition) were washed twice with cold phosphate-buffered saline (PBS), harvested with trypsin, centrifuged at $1500 \mathrm{rpm}$ for $10 \mathrm{~min}$, washed in ice-cold PBS, and fixed in $1.0 \mathrm{ml}-20^{\circ} \mathrm{C} 70 \%$ ethanol. Samples were stained with $1.0 \mathrm{ml}$ dye solution containing $0.02 \mathrm{mg} / \mathrm{ml}$ RNAse A, $1.0 \mathrm{mg} / \mathrm{ml} \mathrm{PI}, 0.003 \mu \mathrm{l} / \mathrm{ml}$ Triton- $X$ and $1.0 \mathrm{mg} / \mathrm{ml}$ sodium citrate in distilled water, and the mixture was incubated for $60 \mathrm{~min}$ at room temperature. After an additional washing step with PBS, cells were analyzed on a FACStar (Beckton-Dickinson, Mountain View, CA, USA). In each analysis, 20,000 events were recorded, and the percentages of the cells in the different cell cycle phases (subG1, G1, S and G2/M) were determined by using winMDI2.9. The subG 1 fraction was regarded as the apoptotic cell population [29]. For statistical evaluation, data were analyzed by one-way ANOVA with the Neumann-Keuls post test, using Prism 4 software.

\subsection{Determination of in situ caspase-3 activity}

To analyze the effect of $\mathbf{1}$ on the activity of caspase-3, one of the executioner enzymes of apoptosis, a commercially available colorimetric assay (Cat. No.: CASP-3-C) was performed. Briefly, near-confluent HeLa cells were seeded in tissue culture flasks (10 ${ }^{7}$ cells/flask) and grown overnight under standard cell culturing conditions. The cells were then incubated with increasing concentrations (from $1.25 \mu \mathrm{M}$ to $5.0 \mu \mathrm{M}$ or $10 \mu \mathrm{M}$ ) of the test compound for 48 and $72 \mathrm{~h}$. After incubation, the cells were counted, centrifuged and washed with PBS. Aliquots containing 10 million cells were suspended in $100 \mu \mathrm{l}$ kit lysis buffer and incubated on ice for $20 \mathrm{~min}$. The lysed cells were subsequently centrifuged and the supernatants were used for the measurement. In accordance with the manufacturer's protocol, $5.0 \mu \mathrm{l}$ portions of treated and untreated supernatants were incubated with $10 \mu$ l acetyl-AspGlu-Val-Asp $p$-nitroaniline, a selective caspase-3 substrate, in a final volume of $100 \mu \mathrm{l}$ in assay buffer. As a control experiment, $5.0 \mu \mathrm{l}$ of each sample was incubated with $10 \mu$ l caspase- 3 substrate and $10 \mu \mathrm{l}$ acetyl-Asp-Glu-Val-Asp-aldehyde, a selective caspase-3 inhibitor, in a final volume of $100 \mu \mathrm{l}$ in assay buffer. Each sample was prepared in five parallels. A standard solution of caspase-3 was used as positive control in parallel with its inhibitor-treated samples. After an overnight incubation at $37^{\circ} \mathrm{C}$, the absorbance of the $p$-nitroaniline released was measured at $405 \mathrm{~nm}$. The concentration of $p$-nitroaniline was calculated from a calibration curve previously prepared with $p$-nitroaniline solutions with known concentrations. The in situ caspase- 3 activity was expressed in $\mu \mathrm{mol}$ $p$-nitroaniline $/ \mathrm{min} / \mathrm{ml}$. For statistical evaluation, data were analyzed by one-way ANOVA with the Neumann-Keuls post test, using Prism 4 software.

\subsection{In vivo uterotrophic assay}

The in vivo effect of compound $\mathbf{1}$, the most effective antiproliferative agent, on the uterus weight was measured in gonadectomized female rats.

The estrogenic effect was determined as reviewed by Sandow [30] with some modifications. Mature female Sprague-Dawley rats (180-200 g) under general anesthesia induced by isoflurane inhalation were ovariectomized. After laparotomy, the oviducts and the arteries supplying the ovaries were ligated on both sides, and the ovaries were excised. The abdomen and the skin were closed with surgical sutures, and the animals were then observed until awakening. Three weeks postoperatively, the test animals (5 animals/group) were injected s.c. daily for 7 days with $\mathbf{1}$ dissolved in olive oil at 10,30 or $50 \mu \mathrm{g} / 0.1 \mathrm{ml}$. The negative and positive control groups received pure olive oil or $10 \mu \mathrm{g} / 0.1 \mathrm{ml} 17 \beta$-estradiol, respectively. On day 8 , the animals were sacrificed, and the uteri were removed and weighed.

The uterus weight was calculated per $100 \mathrm{~g}$ body weight, and the data were statistically analyzed by one-way ANOVA with the Neuman-Keuls post test, using Prism 4 software. The experimental animal protocol was in full accordance with the Guidelines for Animal Experimentation approved by the Animal Experimentation Committee at the University of Szeged.

\section{Results}

\subsection{Antiproliferative (MTT) assay}

In the MTT assay, 2, 3 and $\mathbf{4}$ at concentrations from $0.3 \mu \mathrm{M}$ to $30.0 \mu \mathrm{M}$ did not exhibit substantial cell growth inhibition on any 
A

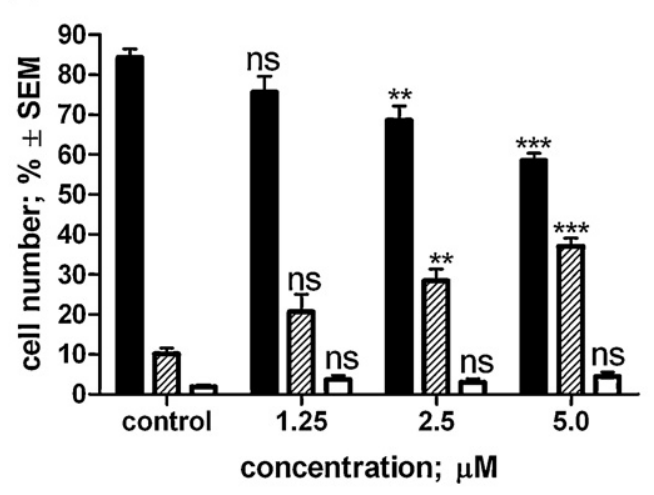

B

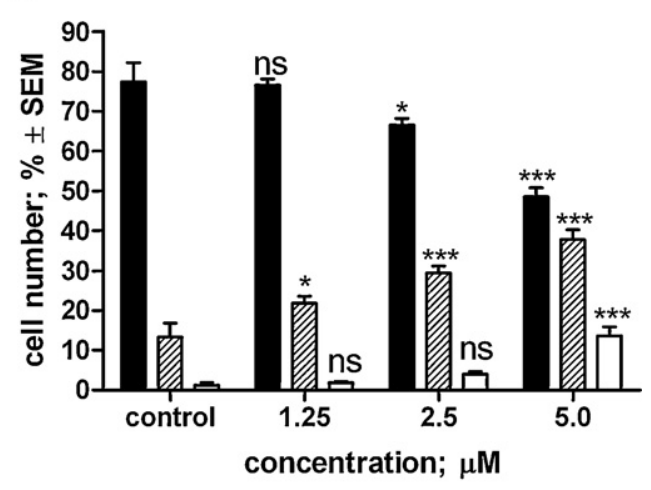

C

$72 \mathrm{~h}$

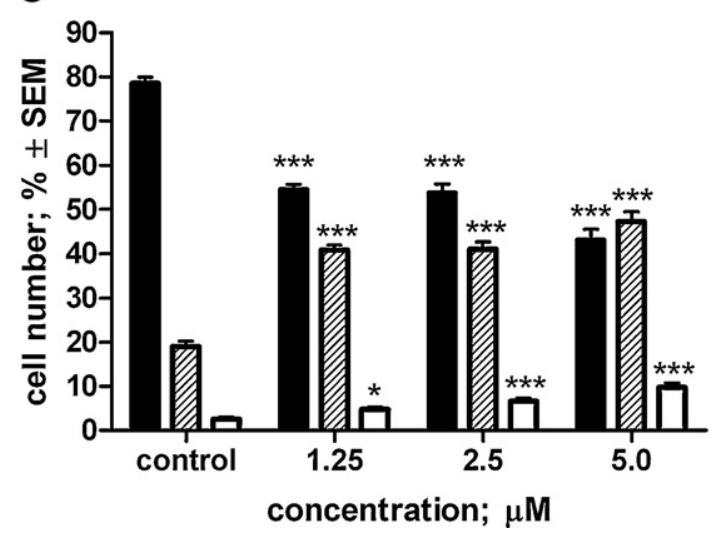

intact

Wmearly apoptosis

$\square$ secondary necrosis

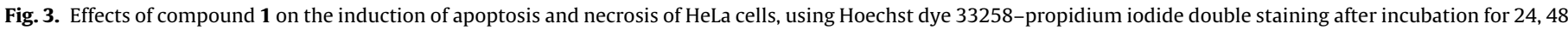

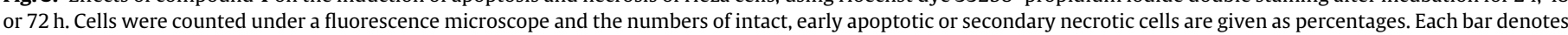
the mean \pm SEM, $n=3$. ns indicates $p>0.05$, ${ }^{*}$ indicates $p<0.05,{ }^{* *}$ indicates $p<0.01$ and ${ }^{* * *}$ indicates $p<0.001$ for the comparisons with the control cell numbers.

of the cell lines $\left(\mathrm{IC}_{50}>20.0 \mu \mathrm{M}\right)$. The growth-inhibition curves of 1 and cisplatin and the $\mathrm{IC}_{50}$ values are presented in Fig. 2 and Table 1.1 proved to be an effective inhibitor of the cell proliferation of HeLa cells $\left(\mathrm{IC}_{50}=5.5 \mu \mathrm{M}\right)$, but did not exert a significant antiproliferative effect on the other cell lines (Table 1 ). The $\mathrm{IC}_{50}$ of cisplatin on HeLa cells was $6.5 \mu \mathrm{M}$. The $\mathrm{IC}_{50}$ of 1 on steroid-depleted MCF-7 cells was in the same range as that on normal MCF-7 cells (Table 1).

1 did not inhibit the proliferation of intact, non-cancerous MRC-5 cells to a significant extent $\left(\mathrm{IC}_{50}>30.0 \mu \mathrm{M}\right)$, whereas cisplatin displayed an $\mathrm{IC}_{50}$ value of $3.7 \mu \mathrm{M}$ on MRC-5 cells (Fig. 2).

Table 1

Calculated $\mathrm{IC}_{50}$ values of D-homoestrone (1), 13-epi-D-homoestrone (2), their 3-methyl ethers (3 and 4, respectively) and cisplatin, measured in the 72-h antiproliferative assay described in the Materials and methods on the HeLa, MCF-7, steroid-depleted MCF-7, Ishikawa and MRC-5 cell lines. n.d. indicates not determined.

\begin{tabular}{lcclll}
\hline Compound & \multicolumn{1}{l}{$\mathrm{IC}_{50}[\mu \mathrm{M}]$} & & \\
\cline { 2 - 6 } & HeLa & MCF-7 & $\begin{array}{l}\text { Steroid-depleted } \\
\text { MCF-7 }\end{array}$ & Ishikawa & MRC-5 \\
\hline $\mathbf{1}$ & 5.5 & $>30$ & $>30$ & 21.2 & $>30$ \\
$\mathbf{2}$ & $>30$ & $>30$ & n.d. & $>30$ & n.d. \\
$\mathbf{3}$ & $>30$ & $>30$ & n.d. & $>30$ & n.d. \\
$\mathbf{4}$ & $>30$ & $>30$ & n.d. & $>30$ & n.d. \\
Cisplatin & 6.5 & 9.6 & n.d. & 3.5 & 3.7 \\
\hline
\end{tabular}

\subsection{Morphological changes in the cells}

HeLa cells were incubated with increasing concentrations of $\mathbf{1}$ $(1.25,2.5$ and $5.0 \mu \mathrm{M})$ for 24,48 or $72 \mathrm{~h}$. The induction of early apoptosis or secondary necrosis was determined according to the nuclear morphology and membrane integrity. 1 at 2.5 and $5.0 \mu \mathrm{M}$ induced significant early apoptosis (30.0-40.0\%) even at $24 \mathrm{~h}$, and this situation was not markedly changed at $48 \mathrm{~h}$. The proportion of secondary necrotic cells was highest, at $15 \%$, on exposure to $5.0 \mu \mathrm{M}$ $1 \mathrm{for} 48 \mathrm{~h}$. At $72 \mathrm{~h}$, the early apoptotic cell population accounted for almost half of the cells at all applied concentrations of 1 (Fig. 3 ), with significant differences from the control. The numbers of secondary necrotic cells in samples treated with $\mathbf{1}$ for $72 \mathrm{~h}$ were also significantly higher than the corresponding controls, but did not differ markedly from the data measured after incubation for $48 \mathrm{~h}$.

\subsection{Cell cycle distribution}

For a quantitative characterization of the action of $\mathbf{1}$ on the cell cycle distribution, HeLa cells were treated with $1.25,2.5$ or $5.0 \mu \mathrm{M} 1$ for $72 \mathrm{~h}$, with 2.5 or $5.0 \mu \mathrm{M} 1$ for $48 \mathrm{~h}$ and additionally with $10.0 \mu \mathrm{M}$ or $20 \mu \mathrm{M} 1$ for $24 \mathrm{~h}$, and the different cell populations were analyzed by flow cytometry after PI staining (Fig. 4). The number of cells in the subG1 phase (indicating apoptosis) did not differ significantly up to $48 \mathrm{~h}$. However, the number of cells in the G2/M phase was already significantly higher after treatment with $20 \mu \mathrm{M}$ 1 for $24 \mathrm{~h}$, and the increase was even higher after treatment with $5.0 \mu \mathrm{M} 1$ for $48 \mathrm{~h}$. At $72 \mathrm{~h}$, a significant, dose-dependent increase 

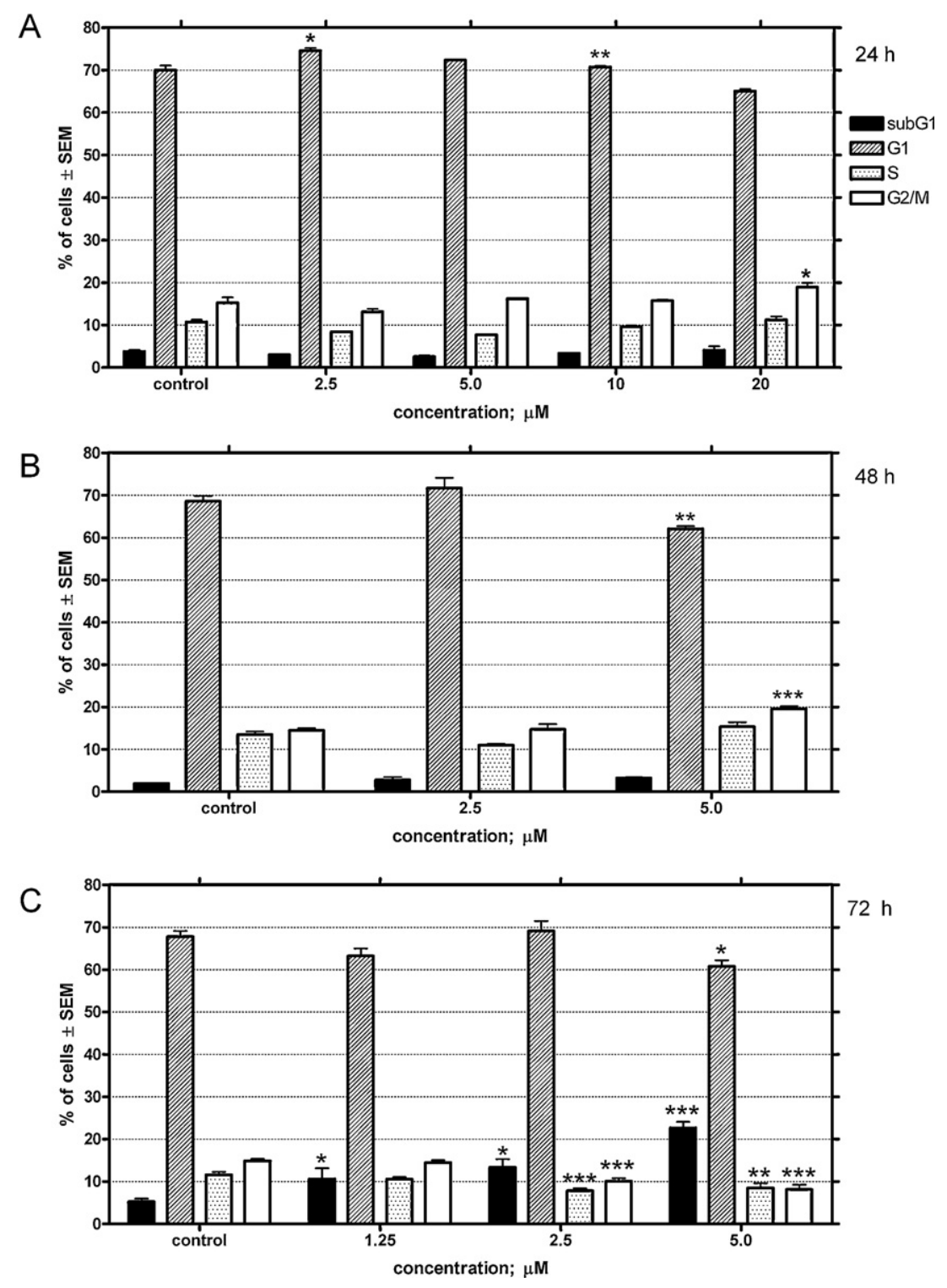

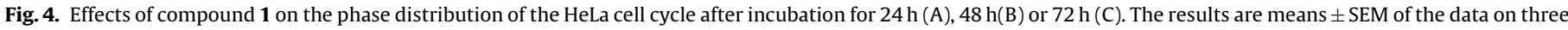

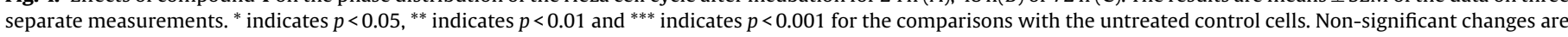
not indicated.

was detected in the number of cells in the subG1 phase, with concomitant decreases in the numbers of cells in the G1 and G2/M phases.

\subsection{In situ caspase-3 activity}

In view of the results of the cell cycle study, the caspase3 activity on HeLa cells was determined after exposure to 1.25 , 2.5 or $5.0 \mu \mathrm{M} 1$ for $72 \mathrm{~h}$. The caspase-3 activity was significantly increased by 1 under all of these conditions as compared with the vehicle-treated control samples, but in this concentration range there was no apparent dose-dependent relationship suggesting the detection of a maximally evoked effect. Following reduction of the length of the incubation period to $48 \mathrm{~h}$ and extension of the applied concentration range of $\mathbf{1}$ to $10 \mu \mathrm{M}$, a significant induction of caspase- 3 activity was likewise observed, indicating the development of apoptosis under all these experimental circumstances. After incubation for $48 \mathrm{~h}$, the exerted induction in caspase- 3 activity can be regarded as dose-dependent. The induction of caspase- 3 activity by the different concentrations of $\mathbf{1}$ was inhibited by the competitive inhibitor of caspase-3 (Fig. 5).

\subsection{In vivo uterotrophic assay}

The weight of the rat uterus following treatment with $\mathbf{1}$ did not differ significantly from that following treatment with olive oil (vehicle control) in any applied dose up to $50 \mu \mathrm{g} / \mathrm{animal}$. In contrast, the administration of $10 \mu \mathrm{g} 17 \beta$-estradiol induced a nearly 5 -fold increase in uterus weight (Fig. 6).

\section{Discussion}

Cancer is still the leading cause of death in economically developed countries and the second leading cause of death in developing countries [31]. Among women, all types of tumors affecting the reproductive organs (the breasts, uterus, cervix and ovaries) were recently reported to be found in the list of the 10 most frequently diagnosed cancers [32]. Cervical cancer is the second most commonly diagnosed cancer affecting the reproductive system in 
A

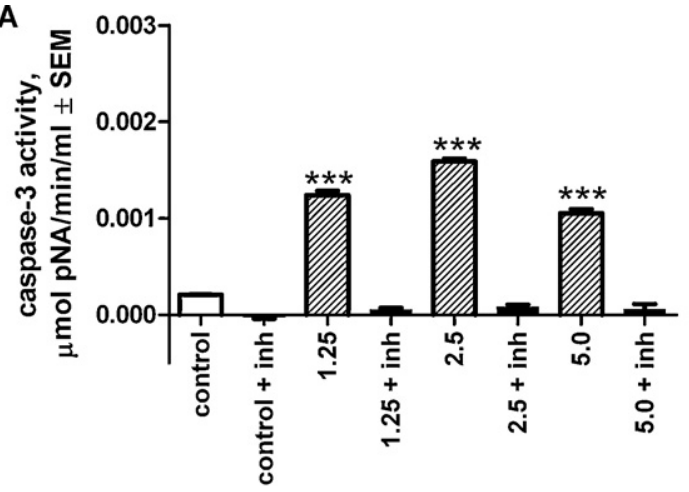

concentration; $\mu \mathrm{M}$

B

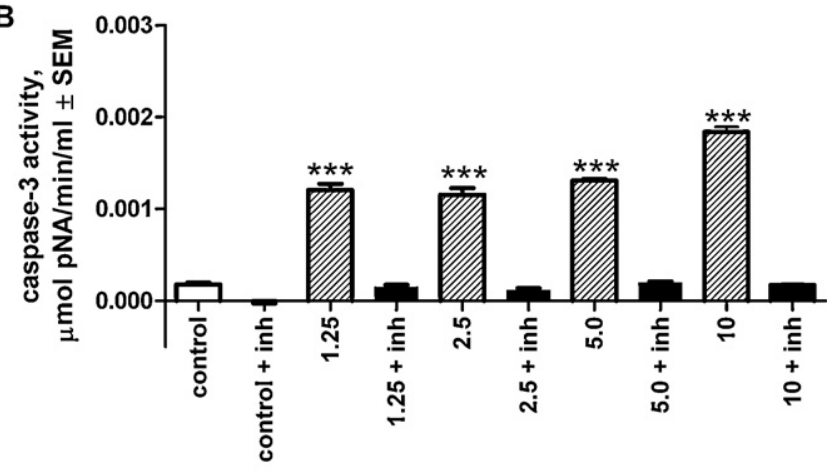

concentration; $\mu \mathrm{M}$

Fig. 5. In situ measurement of caspase-3 activity in HeLa cells after treatment with compound 1 for $72 \mathrm{~h}(\mathrm{~A})$ and $48 \mathrm{~h}(\mathrm{~B})$. The activity of caspase- 3 is expressed as the concentration of $p$-nitroaniline (pNA) released by caspase- 3 from its peptide substrate, acetyl-Asp-Glu-Val-Asp $p$-nitroaniline, during a given period of time. Data are means \pm SEM, $n=5$. ${ }^{* * *}$ indicates $\mathrm{p}<0.001$ as compared with the untreated control samples. The caspase-3 inhibitor (inh), acetyl-Asp-Glu-Val-Asp-aldehyde, suppressed the enzyme activity in all cases.

females worldwide. It accounted for $9 \%$ of the total new cancer cases and $8 \%$ of the total cancer deaths among women in 2008 , with the highest incidence rates among the economically developed countries in Central and Eastern Europe. It is clear that the need for new,

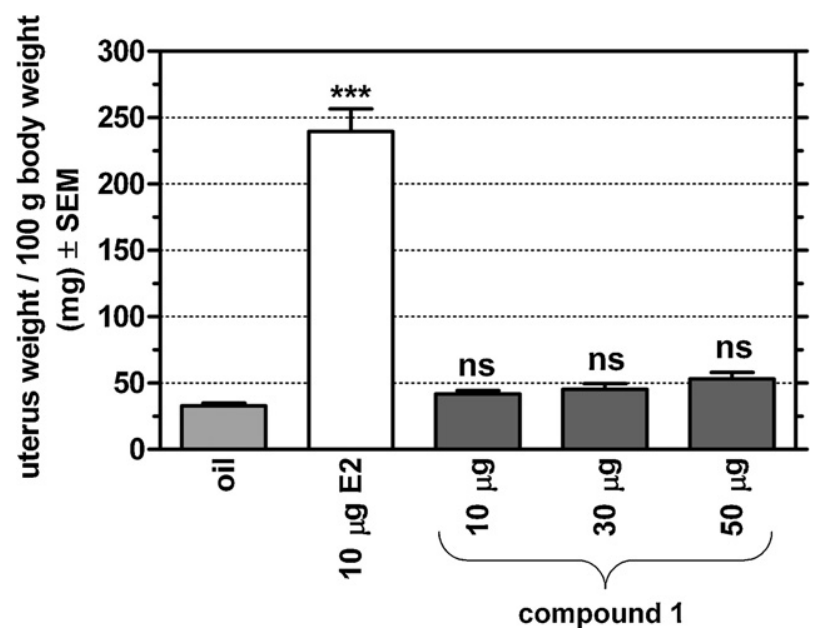

Fig. 6. In vivo effects of 7-day parenteral treatment with compound 1,17 $\beta$-estradiol (E2) or vehicle (olive oil) on the uterus weight in ovariectomized rats. The uterus weight gain is expressed as the tissue weight in $\mathrm{mg}$ per $100 \mathrm{~g}$ of living animal weight. Data are means \pm SEM, $n=5$. ns indicates $p>0.05$ and ${ }^{* * *}$ indicates $p<0.001$ as compared with the olive oil-treated samples. more potent and better tolerated drugs for the therapy of this type of cancer has not declined.

The present paper provides the first convincing data concerning the cell proliferation-inhibiting effects of D-homoestrone, 13-epi-Dhomoestrone and their 3-methyl ethers on human cancer cell lines of reproductive origin. D-Homoestrone proved to be the most effective antiproliferative compound on the human cervical cancer cell line (HeLa), with a potency under our experimental circumstances equivalent to that of cisplatin, one of the drugs used in the routine therapy of cervical carcinomas [33]. As D-homoestrone did not effectively inhibit the multiplication of other types of reproductive cancer cells (e.g. breast and endometrial cells), its antiproliferative effect appears to be specific to HeLa cells. HeLa cells possess a unique feature relative to the other two cell lines of reproductive origin involved in our investigations (MCF-7 and Ishikawa cells): human papilloma virus (HPV) 18 positivity [34]. The expression of HPV-encoded oncoprotein E6 results in the suppressed activity of the wild-type p53 transcription factor, which plays an important role in different steps of cell division [35]. Several compounds (e.g. roscovitine, cidofovir and $2-0-\beta$-D-glucopyranosyl-L-ascorbic acid) have been reported to inhibit the proliferation of HeLa cells selectively. It has been demonstrated that most of these compounds inhibit the expression of the E6 oncoprotein; thus, they abrogate the suppression of $\mathrm{p} 53$, resulting in activation of the p53-dependent apoptotic pathway [36-38]. We postulate that the potential alteration of this signal transduction pathway on the incubation of HeLa cells with D-homoestrone might be the explanation of the specific antiproliferative effect of our test compound.

The results of the antiproliferative assays permit certain conclusions relating to the effects of structure modification. The 13 -methyl group in the $\beta$ position is essential for the significant antiproliferative effect, because the $\mathrm{IC}_{50}$ of 13-epi-D-homoestrone on HeLa cells is at least 6 times higher than that of D-homoestrone. On the other hand, the 3-methoxy derivative of D-homoestrone displayed a markedly weaker proliferation-inhibiting effect on HeLa cells than that of D-homoestrone itself. Thus, it can be concluded that the presence of a 3-hydroxy group on the D-homoestrone skeleton plays an important role in its cell proliferation-inhibiting effect. These data possibly also suggest that D-homoestrone exerts its action on a definite, but as yet undetermined target. Further investigations with variously substituted D-homoestrone analogs might promote further clarification of the structure-activity relationships between the ligand and the target.

Tumor specificity is one of the challenges facing new anticancer drug candidates. 1 did not appear to disturb the proliferation of MRC-5 non-cancerous, fetal lung fibroblast cells. In all applied concentrations, its proliferation-inhibiting effect on fibroblast cells was significantly weaker than that of cisplatin, an observation supported by the negative results on animal toxicity (i.e. no detectable symptoms) during the in vivo treatment of rats for 1 week.

On the basis of the data concerning the common apoptosis markers, 1 can be regarded as a new apoptosis-inducing antiproliferative agent. To investigate the mechanism of the antiproliferative effect of $\mathbf{1}$, HOPI double staining, cell cycle analyses and caspase-3 activity measurements were performed. The apoptosis-inducing effect of 1 was clearly evidenced morphologically by the increased number of cells with condensed DNA that accumulated HO, regarded as one of the initiating steps in programmed cell death [39]. On increase of the incubation period, some of the early-apoptotic cells seemed to be converted to late-apoptotic or secondary necrotic cells by $48 \mathrm{~h}$, as evidenced by a substantial cell population stained with PI. Besides the disrupted membrane integrity, the cells in this transient stage may not exhibit a decreased DNA content [29]. During longer incubation $(72 \mathrm{~h})$, these secondary necrotic cells may demonstrate the markers of substantial DNA elimination, as an increased subG1 population [40] detected by flow cytometry analysis. Further evidence 
of the apoptosis-inducing effect of 1 was provided by the significant increases in the activity of caspase-3, the first executioner enzyme of the caspase family, after the treatment of HeLa cells with $\mathbf{1}$ in all three concentrations applied. The activity of caspase- 3 was demonstrated to depend on the length of incubation with $\mathbf{1}$; the gradual development of programmed cell death resulted in the maximal apoptotic signal after $72 \mathrm{~h}$.

Flow cytometric analysis also revealed some details concerning the mechanism of action of $\mathbf{1}$. The numbers of cells in the G2/M phase were significantly higher after the incubation of HeLa cells with $20 \mu \mathrm{M}$ or $5.0 \mu \mathrm{M} 1$ for 24 or $48 \mathrm{~h}$, respectively. When arrested in the $\mathrm{G} 2 / \mathrm{M}$ phase, these cells may activate the intrinsic apoptotic signal. Significantly increased caspase-3 activity was already measured after the incubation of HeLa cells with $\mathbf{1}$ for $48 \mathrm{~h}$. However, the accumulation of cells in the subG1 population was demonstrated only after $72 \mathrm{~h}$. We hypothesized, that if cells arrested in the G2/M phase enter the process of apoptosis, the immediate appearance of the subG1 population can not be expected because these cells include double DNA content, the degradation of which may first result in particles with nearly simple DNA content, and particles with smaller DNA content may develop only during the next step, which requires several hours. Certain A-ring-substituted estrone derivatives have been demonstrated to exert a similar antiproliferative effect on MDA-MB-231 estrogen receptor-negative, metastatic breast cancer cells [41]. We earlier observed that the 4-methoxyphenylpyrazoline derivative of solanidine inhibits the cell cycle in the G2/M phase, and induces concomitant apoptosis on HL-60 leukemia cells [42]. This mechanism of action can be considered to be frequent among antiproliferative compounds with a sterane skeleton (e.g. diosgenin, ergone, 2-methoxyestradiol, etc.) $[6,43,44]$.

As concerns steroid compounds with structures designed not to exert classical receptorial effects, their binding to and activation of any steroid receptor is an important and intriguing question in connection with their possible future therapeutic use. It has been reported that the estrogen receptor (ER) recognizes $\mathbf{1}$, but its inhibition constant is three orders of magnitude lower than that of the reference molecule, $17 \beta$-estradiol, measured by radioligand-binding assay on immature rabbit uterus cytosol [26]. $\mathbf{1}$ is not able to inhibit significantly the proliferation of ER-positive MCF-7 human breast carcinoma cells [45], growing in general medium, which suggests that it cannot bind and transactivate the human ER either. To test this assumption, the antiproliferative assay was repeated on MCF-7 cells maintained in steroid hormone-depleted medium [46]. Since there was no noteworthy difference between the cell proliferation inhibitory activity of $30 \mu \mathrm{M} 1$ measured on MCF-7 cells maintained in media with or without steroid hormones, it can be concluded that $\mathbf{1}$ does not bind to and activate the human ER in vitro. Furthermore, it is widely accepted that cancer cell lines maintained for in vitro investigations can retain some metabolic capacity for the reactivation of estradiol metabolites [47]. However, most human cancer cell lines have no substantial xenobiotic-metabolizing enzyme activity (e.g. cytochrome enzymes) and therefore no action can be expected from an agent of prodrug type [48]. Thus, ovariectomized rats were treated with $\mathbf{1}$ in three different doses for 7 days in order to obtain information about the possibility of its in vivo conversion to an active metabolite with estrogenic activity. The result that there was no significant gain in uterus weight after the treatment with the test compound relative to the vehicle-treated animals indicates that $\mathbf{1}$ does not exert an estrogenic effect in an in vivo system. Additionally, the preliminary data on the toxic effect of 1 strongly suggested that it does not evoke macroscopic harmful reactions in laboratory rats [49].

In conclusion, our current findings provide the first evidence that 1 selectively suppresses HeLa cell proliferation and modulates the cell cycle progression by promoting several steps of apoptosis and inducing the accumulation of cells in the G2/M phase. Its tumor specificity proved to be more beneficial that that of cisplatin, one of the drugs applied in the therapy of cervical carcinomas. Moreover, it is highly possible that neither $\mathbf{1}$ nor its metabolites possess estrogenic activity. Hence, $\mathbf{1}$ can be considered to be a new, noteworthy and promising lead compound among anticancer candidates.

\section{Acknowledgments}

The project "TÁMOP-4.2.1/B-09/1/KONV-2010-0005 - Creating the Center of Excellence at the University of Szeged" is supported by the European Union and co-financed by the European Social Fund.

\section{References}

[1] R.B. Dickson, G.M. Stancel, Estrogen-receptor mediated processes in normal and cancer cells, Journal of the National Cancer Institute Monographs 27 (2000) $135-145$.

[2] A.O. Mueck, H. Seeger, 2-Methoxyestradiol - biology and mechanism of action, Steroids 75 (2010) 625-631.

[3] M. Cushman, H.M. He, J.A. Katzenellenbogen, C.M. Lin, E. Hamel, Synthesis antitubulin, antimitotic and cytotoxicity of analogs of 2-methoxyestradiol, an endogenous mammalian metabolite of estradiol that inhibits tubulin polymerization by binding to the colchicine binding site, Journal of Medicinal Chemistry 38 (1995) 241-249.

[4] J.M. Day, S.P. Newmann, A. Comninos, C. Solomon, A. Purohit, M.P. Leese, B.V. Potter, M.J. Reed, The effects of 2-substituted oestrogen sulphamates on the growth of prostate and ovarian cancer cells, Journal of Steroid Biochemistry and Molecular Biology 84 (2003) 317-325

[5] J.C. Seegers, M.L. Aveling, C.H. van Aswegen, M. Cross, F. Koch, W.S. Joubert, The cytotoxic effects of estradiol $17 \beta$, catecholestrogens and methoxyestradiol on dividing MCF-7 and HeLa cells, Journal of Steroid Biochemistry 32 (1989) 797-809.

[6] L. Li, S. Bu, T. Baeckström, M. Landström, U. Ulmsten, X. Fu, Induction of apoptosis and G2/M arrest by 2-methoxyestradiol in human cervical cancer HeLaS3 cells, Anticancer Research 24 (2004) 873-880.

[7] A. Joubert, C. Martiz, F. Joubert, Influence of prostaglandin A2 and 2methoxyestradiol on Bax and Bcl-2 expression levels in cervical carcinoma cells, Biomedical Research 26 (2005) 87-90.

[8] L. Li, J. Da, M. Landström, U. Ulmsten, X. Fu, Antiproliferative activity and toxicity of 2-methoxyestradiol in cervical cancer xenograft mice, International Journal of Gynecological Cancer 15 (2005) 301-307.

[9] N. Klauber, S. Parangi, E. Flynn, E. Hamel, R.J. D’Amato, Inhibition of angiogenesis and breast cancer in mice by microtubule inhibitors 2-methoxyestradiol and taxol, Cancer Research 57 (1997) 81-86.

[10] M.L. Lottering, M. Haag, J.C. Seegers, Effects of 17-beta estradiol metabolites on cell cycle events in MCF-7 cells, Cancer Research 52 (1992) 5926-5932.

[11] T. Fotsis, Y. Zhang, M.S. Pepper, H. Adlercreutz, R. Montesano, P.P. Nawroth, L. Schweigerer, The endogenous oestrogen metabolite 2-methoxyoestradiol inhibits angiogenesis and suppresses tumour growth, Nature 368 (1994) 237-239.

[12] S.K. Banerjeei, M.N. Zoubine, D.K. Sarkar, A.P. Weston, J.H. Shah, D.R. Campbell, 2-Methoxyestradiol blocks estrogen-induced rat pituitary tumor growth and tumor angiogenesis: possible role of vascular endothelial growth factor, Anticancer Research 20 (2000) 2641-2645.

[13] N.J. Mabjeesh, D. Escuin, T.M. LaVallee, V.S. Pribluda, G.M. Swartz, M.S. Johnson, M.T. Willard, H. Zhong, J.W. Simons, P. Giannakakou, 2ME2 inhibits tumor growth and angiogenesis by disrupting microtubules and dysregulating HIF, Cancer Cell 3 (2003) 363-375.

[14] M.N. Zoubine, A.P. Weston, D.C. Johnson, D.R. Campbell, S.K. Banerjee 2-Methoxyestradiol-induced growth suppression and lethality in estrogenresponsive MCF-7 cells may be mediated by down regulation of p34cdc2 and cyclin B1 expression, International Journal of Oncology 15 (1999) 639-646.

[15] S. Bu, A. Blaukat, X. Fu, N.E. Heldin, M. Landström, Mechanisms for 2 methoxyestradiol-induced apoptosis of prostate cancer cells, FEBS Letters 531 (2002) 141-151.

[16] K. Shimada, M. Nakamura, E. Ishida, M. Kishi, N. Konishi, Roles of p38- and c-jun NH2-terminal kinase-mediated pathways in 2-methoxyestradiol-induced p53 induction and apoptosis, Carcinogenesis 24 (2003) 1067-1075.

[17] T.H. Lippert, H. Adlercreutz, M. Berger, H. Seeger, W. Elger, A.O. Mueck, Effect of 2-methoxyestradiol on the growth of MNU-induced rat mammary carcinoma, Journal of Steroid Biochemistry and Molecular Biology 84 (2003) 51-56.

[18] C. Sweeney, G. Liu, C. Yiannoutsos, J. Kolesar, D. Horvath, M.J. Staab, K. Fife, V. Armstrong, A. Treston, C. Sidor, G. Wilding, A phase II multicenter, randomized, double-bind, safety trial assessing the pharmacokinetics, pharmacodynamics and efficacy of oral 2-methoxyestradiol capsules in hormone-refractory prostate cancer, Clinical Cancer Research 11 (2005) 6625-6633.

[19] W.L. Dahut, N.J. Lakhani, J.L. Gulley, P.M. Arlen, E.C. Kohn, H. Kotz, D. McNally, A. Parr, D. Nguyen, S.X. Yang, S.M. Steinberg, J. Venitz, A. Sparreboom, W.D Figg, Phase I clinical trial of oral 2-methoxyestradiol, an antiangiogenic and 
apoptotic agent, in patients with solid tumors, Cancer Biology and Therapy 5 (2006) 22-27.

[20] Q. Zhou, D. Gustafson, S. Nallapareddy, S. Diab, S. Leong, K. Lewis, L. Gore, W.A. Messersmith, A.M. Treston, S.G. Eckhardt, C. Sidor, D.R. Camidge, A phase I doseescalation, safety and pharmacokinetic study of the 2-methoxyestradiol analog ENMD-1198 administered orally to patients with advanced cancer, Investigational New Drugs 29 (2011) 340-346.

[21] J. Fishman, C. Martucci, Biological properties of $16 \alpha$-hydroxyestrone: implication in estrogen physiology and pathophysiology, Journal of Clinical Endocrinology and Metabolism 51 (1980) 611-615.

[22] J.H. Clark, B.M. Markaverich, The agonistic and antagonistic effects of short acting estrogens: a review, Pharmacology \& Therapeutics 21 (1983) 429-453.

[23] A.B. Edsall, A.K. Mohanakrishnan, D. Yang, P.E. Fanwick, E. Hamel, A.D. Hanson, G.E. Agoston, M. Cushman, Effects of altering electronics of 2-methoxyestradiol on cell proliferation, on cytotoxicity in human cancer cell cultures, and on tubulin polimerization, Journal of Medicinal Chemistry 47 (2004) 5126-5139.

[24] T.L. Tinley, R.M. Leal, D.A. Randall-Hlubek, J.W. Cessac, L.R. Wilkens, P.N. Rao, S.L. Mooberry, Novel 2-methoxyestradiol analogues with antitumor activity, Cancer Research 63 (2003) 1538-1549.

[25] T. Utsumi, M.P. Leese, S.K. Chander, K. Gaukroeger, A. Purohit, S.P. Newman, B.V. Potter, M.J. Reed, The effects of 2-methoxyestrogen sulphamates on the in vitro and in vivo proliferation of breast cancer cells, Journal of Steroid Biochemistry and Molecular Biology 94 (2005) 219-227.

[26] J. Wölfling, E. Mernyák, É. Frank, G. Falkay, Á. Márki, R. Minorics, Gy. Schneider, Synthesis and receptor-binding examinations of the normal and 13-epi-Dhomoestrones and their 3-methyl ethers, Steroids 68 (2003) 277-288.

[27] T. Mosmann, Rapid colorimetric assay for cellular growth and survival: application to proliferation and cytotoxicity assays, Journal of Immunological Methods 65 (1983) 55-63.

[28] M. Fritzer-Szekeres, I. Savinc, Z. Horvath, P. Saiko, M. Pemberger, G. Graser, A. Bernhaus, M. Ozsvar-Kozma, M. Grusch, W. Jaeger, T. Szekeres, Biochemical effects of piceatannol in human HL-60 promyelocytic leukemia cells synergism with Ara-C, International Journal of Oncology 33 (2008) 887-892.

[29] I. Vermes, C. Haanen, C. Reutelingsperger, Flow cytometry of apoptotic cell death, Journal of Immunological Methods 243 (2000) 167-190.

[30] J. Sandow, Uterus weight, in: H. Gerhard Vogel (Ed.), Drug Discovery and Evaluations. Pharmacological Assays, Springer-Verlag, Berlin/Heidelberg, 2002, pp. 1159-1160.

[31] World Health Organization, The global burden of disease: 2004 update, World Health Organization, Geneva, 2008.

[32] A. Jemal, F. Bray, M.M. Center, J. Ferlay, E. Ward, D. Forman, Global cancer statistics, CA: A Cancer Journal for Clinicians 61 (2011) 69-90.

[33] C. Haie-Meder, P. Morice, M. Castiglione, Cervical cancer: ESMO clinical recommendations for diagnosis, treatment and follow-up, Annals of Oncology 20 (Suppl. 4) (2009) iv27-iv28.

[34] M.M. Pater, A. Pater, Human papillomavirus types 16 and 18 sequences in carcinoma cell lines of the cervix, Virology 145 (1985) 313-318.

[35] M. Scheffner, B.A. Werness, J.M. Hulbreghtse, A.J. Levine, P.M. Howley, The E6 oncoprotein encoded by human papillomavirus types 16 and 18 promotes the degradation of p53, Cell 63 (1990) 1129-1136.
[36] J. Wesierska-Gadek, S. Wandl, M.P. Kramer, C. Pickem, V. Krystof, S.B. Hajek, Roscovitine up-regulates p53 protein and induces apoptosis in human HeLaS3 cervix carcinoma cells, Journal of Cellular Biochemistry 105 (2005) 1161-1171.

[37] G. Andrei, R. Snoeck, D. Schols, E. De Clercq, Induction of apoptosis by cidofovir in human papillomavirus (HPV)-positive cells, Oncology Research 12 (2001) 397-408.

[38] Z. Zhang, X. Liu, T. Wu, J. Liu, X. Zhang, X. Yang, M.J. Goodheart, J.F. Engelhardt, Y. Wang, Selective suppression of cervical cancer HeLa cells by $2-O-\beta-D-$ glucopyranosyl-L-ascorbic acid isolated from the fruit of Lycium barbarum L., Cell Biology and Toxicology 27 (2011) 107-121.

[39] A. Sarastre, K. Pulkki, Morphologic and biochemical hallmarks of apoptosis, Cardiovascular Research 45 (2000) 528-537.

[40] M.C. O’Brien, S.F. Healy Jr., S.R. Raney, J.M. Hurst, B. Avner, A. Hanly, C. Mies, J.W. Freeman, C. Snow, S.K. Koester, W.E. Bolton, Discrimination of late apoptotic/necrotic cells (type III) by flow cytometry in solid tumors, Cytometry 28 (1997) 81-89.

[41] A. Stander, F. Joubert, A. Joubert, Docking, synthesis and in vivo evaluation of antimitotic estrone analogs, Chemical Biology \& Drug Research 77 (2011) 173-181.

[42] R. Minorics, T. Szekeres, G. Krupitza, P. Saiko, B. Giessriegl, J. Wölfling, É. Frank, I. Zupkó, Antiproliferative effects of some novel solanidine analogues on HL-60 human leukaemia cells in vitro, Steroids 76 (2011) 156-162.

[43] M.J. Liu, Z. Wang, Y. Ju, R.N. Wong, Q.Y. Wu, Diosgenin induces cell cycle arrest and apoptosis in human leukemia K562 cells with the disruption of $\mathrm{Ca}^{2+}$ homeostasis, Cancer Chemotherapy and Pharmacology 55 (2005) 79-90.

[44] Y.Y. Zhao, X. Shen, X. Chao, C.C. Ho, X.-L. Cheng, Y. Zhang, R.-C. Lin, K.-J. Du, W.J. Luo, J.-Y. Chen, W.-J. Sun, Ergosta-4,6,8(14),22-tetraen-3-one induces G2/M cell cycle arrest and apoptosis in human hepatocellular carcinoma HepG2 cells, Biochimica et Biophysica Acta 1810 (2011) 384-390.

[45] K.B. Horwitz, M.E. Costlow, W.L. McGuire, MCF-7; a human breast cancer cell line with estrogen, androgen, progesterone, and glucocorticoid receptors, Steroids 26 (1975) 785-795.

[46] Y. Wang, J.L. Dean, E.K.A. Millar, T.H. Tran, C.M. McNeil, C.J. Burd, S.M. Henshall, F.E. Utama, A. Witkiewicz, H. Rui, R.L. Sutherland, K.E. Knudsen, E.S. Knudsen, Cyclin D1b is aberrantly regulated in response to therapeutic challenge and promotes resistance to estrogen antagonists, Cancer Research 68 (2008) 5628-5638.

[47] M.-A. Fournier, D. Poirier, Estrogen formation in endometrial and cervix cancer cell lines: involvement of aromatase, steroid sulfatase and $17 \beta$-hydroxysteroid dehydrogenases (types 1, 5, 7 and 12), Molecular and Cellular Endocrinology 301 (2009) 142-145.

[48] M.T. Donato, A. Lahoz, J.V. Castell, M.J. Gomez-Lechon, Cell lines: a tool for in vitro drug metabolism studies, Current Drug Metabolism 9 (2008) 1-11.

[49] G. Möller, D. Deluca, C. Gege, A. Rosinus, D. Kowalik, O. Peters, P. Droescher, W. Elger, J. Adamski, A. Hillisch, Structure-based design, synthesis and in vitro characterization of potent 17beta-hydroxysteroid dehydrogenase type 1 inhibitors based on 2-substitutions of estrone and D-homo-estrone, Bioorganic \& Medicinal Chemistry Letters 19 (December (23)) (2009) 6740-6744. 